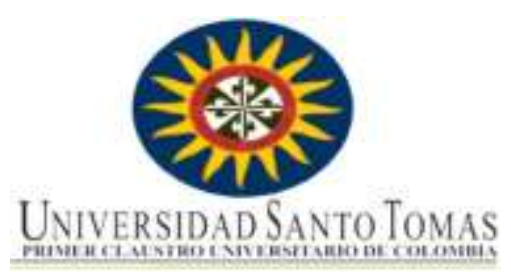

Indicadores corporales y representaciones sociales acerca de la estética en jóvenes a partir de sus fotos de perfil en Facebook.

Jazmín Adriana Rubiano Rubiano

Universidad Santo Tomás

Maestría en Comunicación, Desarrollo y Cambio Social

Bogotá, Colombia

2018 


\title{
Indicadores corporales y representaciones sociales acerca de la estética en jóvenes a partir de sus fotos de perfil en Facebook.
}

\author{
Jazmín Adriana Rubiano Rubiano
}

Trabajo de investigación presentado como requisito parcial para optar al título de:

Magister en Comunicación, Desarrollo y Cambio Social

\author{
Director (a): \\ María Teresa Suárez González
}

Línea de Investigación:

Narrativas, representaciones y tecnologías mediáticas

Universidad Santo Tomás

Facultad de Comunicación Social

Bogotá, Colombia

2018 


\section{Dedicatoria y agradecimientos}

A mis padres.

Por siempre creer en mis capacidades y estar en cada parte de mi proceso de formación académica a lo largo del tiempo.

Agradezco especialmente a mi tutora, la maestra María Teresa Suárez, por haberse convertido en una luz en el camino, que me supo guiar en gran parte del proceso de este gran reto.

Agradecimiento especial a los jurados: Mónica Valencia Calderón y Bernardo Alfredo Hernández Umaña por su valioso aporte a mi trabajo

Agradecimiento especial a Javier Gómez por su colaboración y apoyo en este proceso. 


\section{Resumen}

En Facebook, el joven tiende a presentarse a sí mismo a partir de las fotos que publica en su perfil. Es usual que en ellas muestre su versión más atractiva. De ahí que surja este cuestionamiento: cómo comprender los sentidos de las representaciones sociales de los jóvenes acerca de la estética en sus fotos de perfil en Facebook, a partir de los significados que dan al tipo de indicadores corporales que muestran en ellas, tales como como: ropa, accesorios y posturas. Para abordarlo, se identificaron, describieron y analizaron dichas representaciones. El enfoque metodológico usado fue mixto (cualitativo y cuantitativo), con preponderancia cualitativa. El enfoque epistemológico fue hermenéutico interpretativo. Por su parte, El método seleccionado fue el estudio de caso. Las técnicas de investigación usadas fueron: sondeo exploratorio, talleres y entrevista semiestructurada, observación participante y diario de campo. Se utilizaron tres instrumentos para recoger la información:1) cuestionario de preguntas abiertas (sondeo exploratorio), 2) cuadro de elementos significativos y 3) mapa semántico. Se trabajó con jóvenes de estratos uno y dos, pertenecientes a la localidad de Usme en Bogotá. Como resultado principal, se encontró que las representaciones en cuestión, están atravesadas por los discursos y cánones estéticos presentes en el contexto cultural de los jóvenes, pero que, sin embargo, dichas representaciones no se evidencian igual en la totalidad de los jóvenes.

\section{Palabras clave}

Jóvenes, representaciones sociales, estética, imagen, foto, corporeidad. 


\section{Contenido}

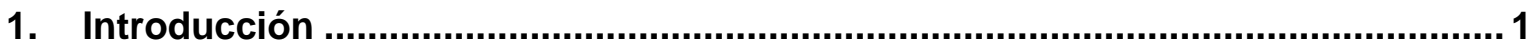

2. Capítulo I. Problema de investigación, preguntas orientadoras y objetivos .......7

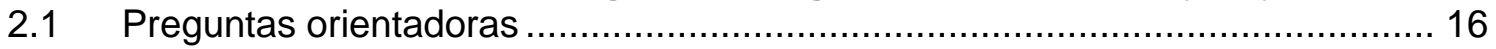

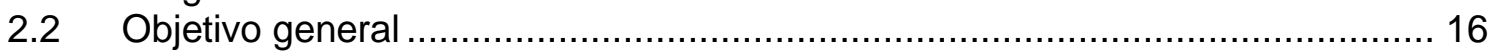

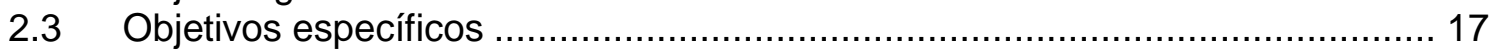

3. Capítulo II. Antecedentes de investigación .........................................................18

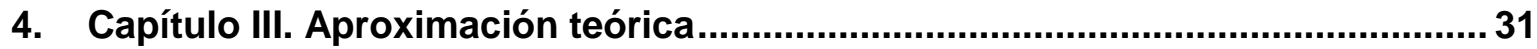

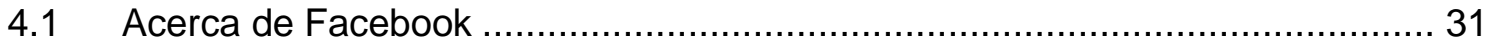

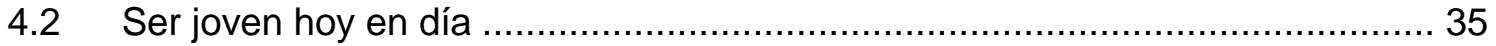

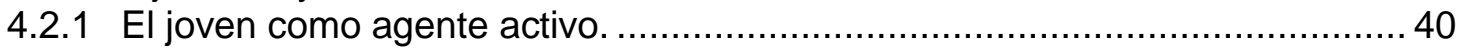

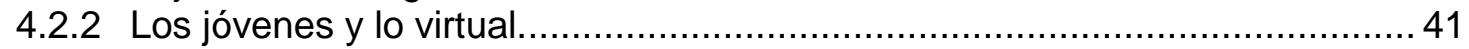

4.3 Representaciones sociales............................................................... 49

4.4 Aproximación al concepto de estética ………….................................... 57

4.5 Apreciaciones sobre el concepto de corporeidad ........................................ 63

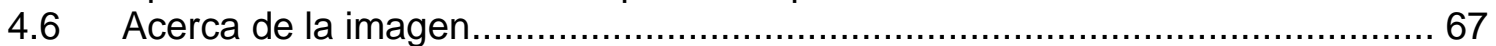

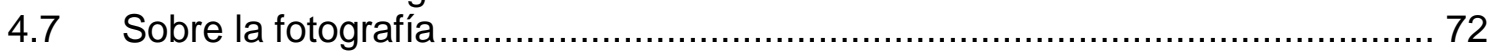

5. Capítulo IV. Aproximación metodológica ..........................................................78

5.1 Enfoque y paradigma en que se enmarca la investigación .............................. 78

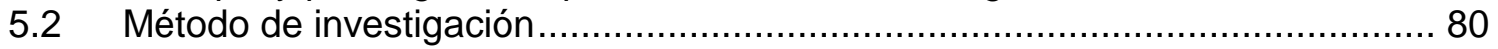

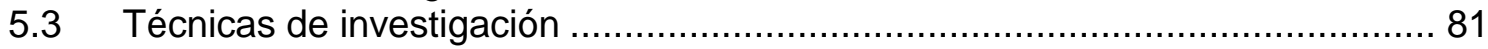

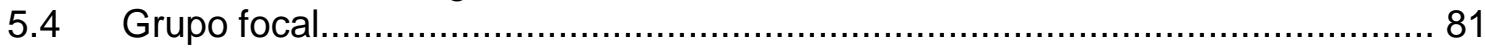

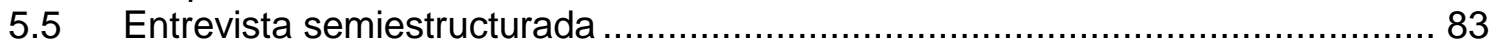

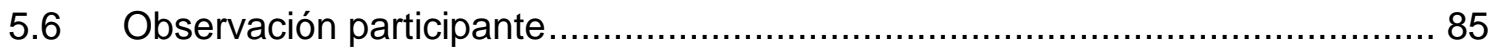

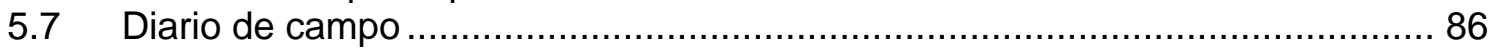

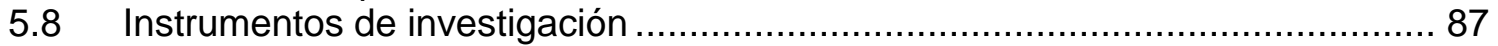

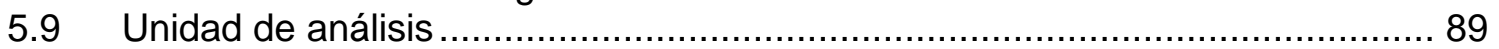

5.10 Contextualización de los jóvenes de la investigación ..................................... 89

5.11 Fases de la investigación ...................................................................... 90

5.11.1 Fase uno: sondeo exploratorio. Instrumento 1 .......................................90

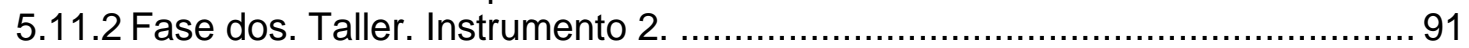

5.11.3 Fase tres. Instrumento 3: mapa semántico ……....................................92

5.11.4 Fase cuatro. Entrevista semiestructurada grupal ...................................... 94

5.11.5 Fase cinco. Análisis de información ..............................................................95

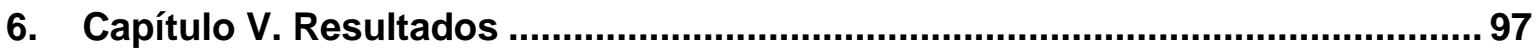

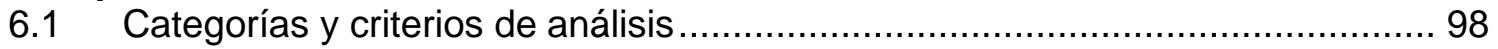

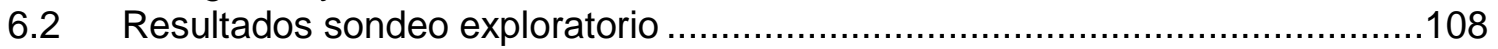

6.3 Resultados obtenidos con cuadro de elementos significativos .....................117

6.4 Resultados obtenidos con mapa semántico …………..............................128 
6.5 Resultados obtenidos con entrevista semiestructurada .131

6.6 Representaciones sociales de los jóvenes acerca de la estética ....................139

6.6.1 Representación: apariencia de felicidad. ............................................... 139

6.6.2 Representación social: apariencia de belleza. ......................................... 144

6.6.3 Representación social del reconocimiento......................................... 147

6.6.4 Representación social: personalización. ................................................. 149

6.6.5 Conexiones entre las representaciones sociales de la estética en jóvenes.. 154

7. Capítulo VI. Discusión de resultados................................................................ 157

7.1 Jóvenes y emergencia de otro tipo de estéticas .........................................171

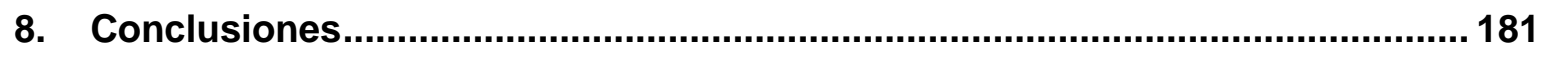

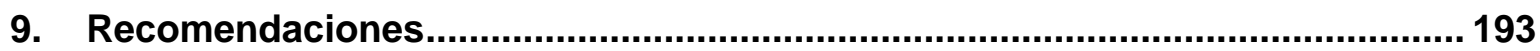

10. Referencias bibliográficas ......................................................................... 195

11. ANEXOS .......................................................................................................... 201

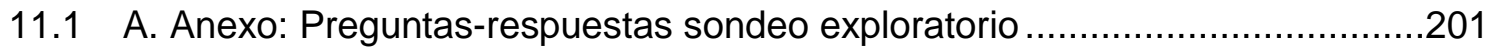

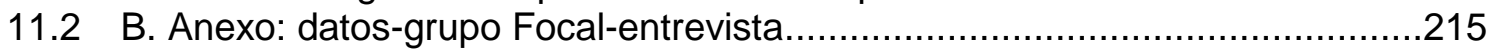

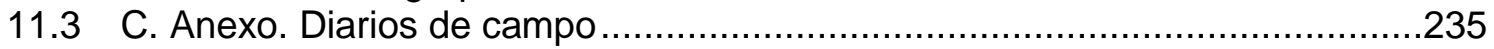

11.4 D. Anexo. Instrumento 1. (Cuestionario de preguntas sondeo exploratorio) ..242

11.5 E. Anexo. Instrumento 2. Cuadro de elementos significativos. .........................243

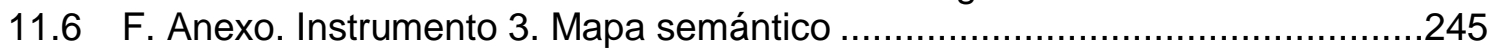

11.7 G. Muestras de cuadros completados por jóvenes: instrumento $2 \ldots \ldots \ldots \ldots \ldots \ldots . . .246$

11.8 H. Muestras de mapas semánticos completados por jóvenes: instrumento 3.249 


\section{Contenido de Tablas y Figuras}

Tabla 1 - Preguntas entrevista semiestructurada ....................................................... 84

Tabla 2 - Categorías y criterios de análisis .................................................................... 98

Tabla 3 - Preguntas y respuestas sondeo exploratorio................................................. 110

Tabla 4 - Conceptos más mencionados y porcentajes (hombres y mujeres) .................... 120

Tabla 5 - Conceptos más mencionados y porcentajes en mujeres ................................... 124

Tabla 6 - Conceptos más mencionados y porcentajes en hombres .................................. 125

Tabla 7 - Preguntas entrevista semiestructurada ...................................................... 132

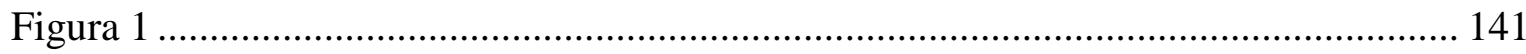

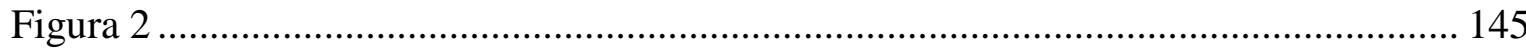

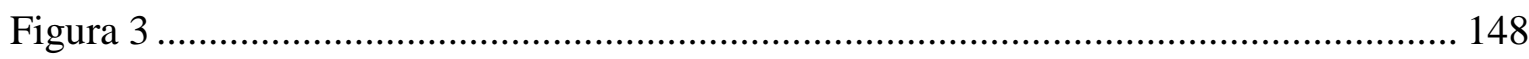

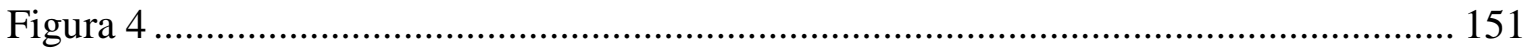

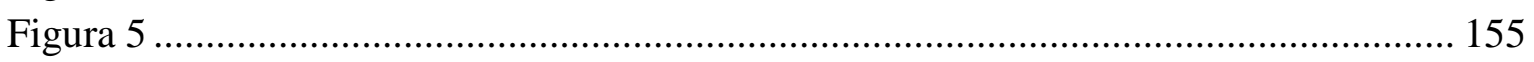




\section{Introducción}

En los contextos actuales en que se desenvuelven los jóvenes, Internet y las posibilidades de interacción que brinda a los usuarios, ha permitido el advenimiento de múltiples formas de socializar. Uno de esos espacios es Facebook.

Allí los jóvenes tienen la posibilidad de crear y personalizar sus perfiles de acuerdo a sus gustos y preferencias. Para hacerlo, usualmente agregan una foto de perfil que es pública. Dicha foto, cobra gran importancia para el joven, dado que desde ella muestra la imagen personal que espera proyectar. De ahí que elabore cuidadosamente sus fotos en las que, por lo general, espera lucir atractivo o bello.

Ahora, si nos preguntamos cómo se comprende lo estético por parte de los jóvenes, es decir, bajo qué criterios se aprecia que una foto de perfil contiene elementos estéticos, surge el cuestionamiento acerca de cuáles son las representaciones sociales de los jóvenes acerca de la estética en sus fotos de perfil en Facebook, específicamente a partir del tipo de posturas corporales, ropa y accesorios que muestran en dichas fotos. Nos centraremos en los significados que dan los jóvenes a dichos elementos, porque se considera que, en la actualidad, se han convertido en unos signos cuyo uso podría indicar qué se considera importante resaltar en una foto y qué no.

Se escogió este tema, porque se considera que si se logra comprender cuáles son y qué sentidos tienen esas representaciones sociales, se puede ampliar el campo de análisis sobre qué factores contextuales están interviniendo para que los jóvenes se presenten a sí mismos en sus fotos de perfil de ciertas maneras. 
Es decir, interesa analizar qué conexiones existen entre los ideales estéticos social y culturalmente aceptados, con el tipo de representaciones sociales de la estética que tienen los jóvenes. Lo anterior, nos permitirá comprender si dichas representaciones se ligan con algunos modelos de belleza bastante convenientes a las lógicas consumistas promulgadas por el mercado. Siendo esta la hipótesis central de esta investigación.

El objetivo central de este trabajo es comprender los sentidos de las representaciones sociales de los jóvenes de la muestra acerca de la estética, manifestadas a partir de los significados que dan a los indicadores corporales que muestran en sus fotos de perfil en Facebook. Para lograrlo, se han propuesto tres objetivos específicos. El primero, apunta a identificar las representaciones sociales de la estética que tienen los jóvenes, manifestadas a partir los significados que dan a los indicadores corporales que muestran en sus fotos de perfil en Facebook. El segundo, se enfoca en describir esas representaciones. El tercero, nos lleva a analizar dichas representaciones, teniendo en cuenta aspectos socioculturales de los jóvenes y del medio donde se desenvuelven.

Con esta investigación se espera aportar a la reflexión acerca de cómo los relatos comúnmente aceptados acerca de lo que se considera estético o no, pueden empezar a ser cuestionados y, por qué no, abrir el camino para que los jóvenes puedan, desde sí mismos, vislumbrar cada vez más otras posibilidades de sentido frente a lo estético, que, no necesariamente, se correspondan con los que se difunden desde las industrias culturales y el mercado en general.

No se pretende, sin embargo, realizar una profundización acerca de cuáles son exactamente los consumos culturales que se conectan con las representaciones sociales de 
los jóvenes, ni cómo cada uno de ellos, por ejemplo, la música, el cine o la publicidad, crearían esas representaciones, pues esto merecería un trabajo de investigación por aparte.

El enfoque teórico que predomina en este trabajo es la corriente posmoderna en sociología. Lo que se ve reflejado en las ideas que se retoman de autores como Lipovetsky (2003), Bauman (2007), Sibilia (2008), Debray (1994). Se escogió esta corriente de pensamiento, debido a que algunos de sus postulados se acercan al tipo de aproximación analítica que se realiza; por ejemplo, el cuestionamiento que se hace a los relatos que han modelado a las representaciones y prácticas sociales que se ven normalizadas desde lo cultural. También se simpatiza con esta corriente de pensamiento, porque se considera que no existen verdades absolutas, ni discursos que puedan acreditarse tener la última palabra frente a los fenómenos sociales. Se opta más bien por intentar comprenderlos en conexión con la situación histórica y cultural de los sujetos.

La línea de investigación en que se inscribe este trabajo al interior de la Maestría en Comunicación, Desarrollo y Cambio social es la de Narrativas, representaciones y tecnologías mediáticas. Se escogió porque se pretende aportar a la discusión acerca de cómo ciertas narrativas cultualmente aceptadas, se conectarían con las representaciones sociales de los jóvenes sobre la estética, dejando abierta la discusión para nuevas posibles investigaciones que analizaran, por ejemplo, cómo se podrían empezar a modificar esos relatos para lograr transformaciones sociales.

Este trabajo está organizado en seis capítulos. El capítulo I presenta de forma ampliada la problematización y pregunta central que da pie a esta investigación. Acto seguido, 
aparecen las preguntas que orientaron el planteamiento de los objetivos, que aparecen inmediatamente después, jerarquizados desde el principal hasta los específicos.

En el capítulo II se presenta un estado de la cuestión acerca del tema de esta investigación. Se retomarán las investigaciones: de Morduchowicz (2012) Chaparro, Echeverry, Bonacci, (2013), entre otras, quienes coinciden en afirmar que, en nuestras sociedades, el contexto cultural de los jóvenes estaría conectado con la tendencia a mostrar, a partir de las redes sociales, la versión que consideran más atractiva de sí mismos.

El capítulo III, presenta una aproximación a las categorías teóricas que sustentan este trabajo. La primera de ellas, es la de red social, específicamente: Facebook. En este apartado se abordará cómo se ha venido incrementando por parte de los jóvenes el uso de las redes sociales virtuales y el impacto que ha tenido esta red social en el contexto contemporáneo. Para hacerlo, se retoman los trabajos realizados por: Aguirre (2011), López (2010), Gurevich, 2016), (Villi, 2010). La segunda categoría desarrollada es la de joven. Esta se focalizará en autores que lo comprenden como a un ser activo, alejado de las posturas que lo conectan con un ser carente en comparación con el adulto, concibiéndolo más bien como un agente de cambio social que, sin embargo, se encuentra fuertemente atravesado por los discursos imperantes en su contexto. Los autores que se referenciarán son: Reguillo (2007), Margulis y Urresti (1996), entre otros. La siguiente categoría es la de representaciones sociales. Para ello, se retomó especialmente el enfoque estructural de las representaciones sociales de Abric (2001) y las teorizaciones de Jodelete (1984) que las desarrolla desde una postura más cercana al lenguaje. La siguiente categoría 
que se encontrará es la de estética. Se identificaron algunas de las ideas teóricas que han servido para comprender mejor este concepto, desde autores como: Ortega y Gasset (1992), Heidegger (1958) y que conectan a la estética con la experiencia artística, hasta autores como Adorno (1970), que analiza cómo la estética empieza a convertirse en estetización en las sociedades postindustriales. La categoría que sigue es la de corporeidad. En este estudio se privilegiaron las perspectivas que vinculan este concepto con la interacción con los demás y con el entorno cultural al que se pertenece. De ahí que se incluyan autores como: Merleau Ponty (1993), Rico (1998), Heidt (en Fernández, Zelich y Monter ,2004). La categoría que sigue es la de imagen. Se recopilaron autores que reflexionan acerca de cómo la imagen se ha ido convirtiendo en un signo cuyo valor representativo, va perdiendo fuerza en los contextos virtuales de hoy en día. Para ello, se revisaron los trabajos de autores como: Debray (1994), Manovich (2005), Bauman (2007), Darley (2002). La última categoría de este apartado es la de fotografía. Se referencian autores que analizaron cómo ha sido el desarrollo de la foto desde sus inicios, tales como: Barthes (1989), Benjamin (2015), hasta nuestros días como: Debray (1994) Manovich (2005), Darley (2002), entre otros.

En el capítulo IV, aparece el enfoque metodológico usado que fue mixto (cualitativo y cuantitativo), con preponderancia cualitativa, así como una explicación de por qué se trabajó con el enfoque epistemológico hermenéutico interpretativo. También se encuentra la descripción del método seleccionado, que fue el estudio de caso, así como la de las técnicas de investigación utilizadas: sondeo exploratorio, talleres, entrevista semiestructurada, observación participante y diario de campo. Luego se describen los tres instrumentos para recoger la información: cuestionario de preguntas abiertas (sondeo 
exploratorio) cuadro de elementos significativos y mapa semántico. En este apartado también se realiza la contextualización de los jóvenes participantes y se describen las fases y pasos en que se realizó la investigación.

En el capítulo V, aparece en primer lugar las categorías de análisis y criterios tenidos en cuenta al iniciar la investigación. Acto seguido se describen y analizan los resultados obtenidos al analizar los datos recogidos con cada técnica e instrumento de investigación aplicados. Después se identifican, describen y analizan las representaciones sociales de los jóvenes, en cumplimiento a los tres objetivos específicos. En este apartado se incluye un análisis acerca de las conexiones halladas por el investigador entre esas representaciones sociales.

En el capítulo VI, aparecen la discusión de los resultados del capítulo anterior, con algunas de las posturas de autores que han sido fundamentales desde el inicio de esta investigación, tales como: Bauman (2007), Sibilia (2008) y Lipovetsky (2003), así como con autores que fueron abordados posteriormente, de acuerdo a las necesidades teóricas que fueron surgiendo después de realizar el trabajo de campo y analizar los resultados, tales como: Feixa (1999) y Muñoz (2010). Por último, aparecerá el apartado de las conclusiones y recomendaciones, en donde se retomaron los hallazgos y análisis más significativos en esta investigación. Finalizando con la sesión dedicada a bibliografía y anexos. 


\section{Capítulo I. Problema de investigación, preguntas orientadoras y objetivos}

En los contextos actuales en donde la información está a la orden del día, especialmente en Internet, han emergido formas de socialización en donde los encuentros entre personas no son ya, como solían ser antes de la década del noventa, tan presenciales desde el punto de vista físico; más bien se ha optado por contactar y mantener interacción con los demás a través de plataformas virtuales que contienen en sí mismas elementos tan variados como: imágenes, fotografías, información personal. Desde allí incluso se brinda la posibilidad de chatear, compartir datos, música, enlaces entre otros elementos que vehiculiza la web.

Una de las redes virtuales que mayor acogida ha tenido en el ámbito mundial es Facebook, siendo este el espacio virtual en donde cientos de jóvenes publican variedad de información, que va desde fotos, comentarios, entre otras formas de expresión. En Facebook, las personas tienen la alternativa de publicar fotos que pueden ser guardadas en álbumes online que es posible restringir a voluntad, de modo que solo algunos tienen el permiso para acceder a los contenidos que allí se almacenan.

En un espacio como Facebook, la imagen de perfil se convierte en el pretexto para crear comentarios y expresar opiniones a través de los recursos que brinda la plataforma. Ejemplo de ello, es la opción de dar un “me gusta”, tanto a las publicaciones propias, como a las de otros usuarios, lo que se ha convertido en un índice de medición que utilizan muchos jóvenes para saber qué tanta acogida tuvo una publicación (Morduchowicz, 2012). De hecho, para gran parte de los jóvenes, incluso el no recibir un "me gusta” puede crear la impresión de que lo que publicó no es del todo bueno, o que no consiguió el grado de aprobación esperado por parte de sus pares (Morduchowicz, 2012). 
Desde investigaciones como las de Morduchowicz (2012) Chaparro, Echeverry, Arévalo (2014), Almansa, Fonseca, Castillo (2013), Dillon (2013); Basile y Linne (2014), Bonacci, (2013) todo parece apuntar a que, evidentemente, los jóvenes se esfuerzan por mostrar en las redes sociales la mejor versión de sí mismos a través de la imagen. O, por lo menos, la mejor desde ciertos cánones de belleza que se producen y reproducen desde el medio social y cultural.

Dicho perfil cobra gran importancia, no solo por ser visible para todos, sino porque se convierte en la carta de presentación de los usuarios. Allí la foto o imagen que se publica, se constituye en el sello personal de los jóvenes, quienes buscan convertir ese espacio en algo que les sea propio. De ahí que tomar y seleccionar una foto de perfil, se transforma en todo un ritual, en el que se ensayan poses y gestos, se escogen accesorios, entre otros signos que están cargados de sentidos socialmente compartidos. Tal ritual demanda tanta atención de los jóvenes, porque estos buscarían que sus fotos de perfil les brinden reconocimiento social por parte de sus pares (Morduchowicz, 2012).

Este espacio virtual, así como muchos otros que se inscriben en la actual sociedad hiperconectada, promulga abiertamente la libertad de los usuarios para elegir la imagen personal que quieren proyectar a los demás, a menudo estimulando a los mismos a publicar imágenes de sí mismos en diferentes situaciones, especialmente cotidianas o en donde se está pasando bien (Morduchowicz, 2012). De hecho, en nuestros días es común encontrar plataformas virtuales, programas de televisión y todo tipo de avisos publicitarios que difunden el estilo de vida deseable en la sociedad actual, que se caracteriza usualmente por lograr una estabilidad económica, que permita a los sujetos ser consumidores viables 
de todo tipo de productos que le asegurarían la calidad de vida a la que todos deberíamos aspirar (Bauman, 2007).

De hecho, el mismo ideal de belleza va siendo perfilado desde los medios masivos. Por doquier, los sujetos, entre ellos los jóvenes, encuentran modelos que les indican cómo deben lucir hoy en día para ser catalogados como bellos y ser aceptados por los demás. Aparece entonces el ideal de mujer delgada, femenina, que, a la vez es sensual y atrevida, o el del hombre varonil, fuerte, pero que a la vez luce interesante, entre otros prototipos que circulan en los discursos que manejan hoy en día industrias culturales como la televisión e Internet. Lo problemático aparece cuando nos preguntamos por los intereses que están de fondo en esa tendencia por homogeneizar lo que significa ser bello o poseer ciertos atributos estéticos deseables para otros. Ya no se trataría, como señalaba Deleuze (1991) de disciplinar a los cuerpos, como ocurría en la fábrica, prisión o en los hospitales. Más bien, han ido surgiendo otro tipo de técnicas que permiten a las hegemonías tener el control de los sujetos a través de la seducción (Lipovetsky,2003). Se trata de unos sofisticados mecanismos de control social que, a través de estrategias placenteras y que apuntan a la satisfacción de algunos instintos, logran hacer creer que el poder de elección sobre quién se espera ser y mostrar está en los usuarios, cuando lo más común es que las opciones sobre las cuales se elige, estén determinadas de antemano (Lipovetsky,2003).

A través de la imagen y de los poderosos mensajes que circulan por todas partes en las sociedades de control Deleuze (1991), se va perfilando el tipo de individuo que encaja con los modelos estéticos a los que se supone, todos deberíamos llegar para considerarnos realizados. De ahí que se considere que, a partir de espacios virtuales como Facebook, y, 
específicamente desde los sentidos que los jóvenes dan a los elementos significativos que ponen en sus fotos de perfil, se podría intentar rastrear el tipo de representaciones que manifiestan en esas imágenes, para analizar qué aspectos culturales, económicos y sociales atraviesan a dichas representaciones.

Una de las razones que lleva a tratar de comprender los sentidos de dichas representaciones, es que se considera necesario empezar a mirar reflexivamente a los discursos y significados que circulan en los medios, para así poder deconstruir algunos significados que se han ido normalizando. Un claro ejemplo de ello, está en aquello que se considera tiene unas características estéticas deseables. Por supuesto se plantea que los mismos jóvenes deben empezar a agudizar más su sentido crítico frente a esos modelos estéticos que encuentran por todas partes y que parecen indicar que el único modo de vida deseable es aquel que se les asemeja. En concordancia con Deleuze (1991), afirmamos que corresponde a los jóvenes encontrar la respuesta acerca de para qué se les estaría usando (Deleuze, 1999); es decir, qué aspectos de fondo existen en esos discursos que promulga el mercado sobre qué se considera un buen vivir. Lo anterior corresponde con la lectura de los jóvenes como unos sujetos activos, capaces de resignificar los discursos que aparecen en las industrias culturales y en la mayoría de medios masivos, entre los que estaría Internet. Pero, para hacerlo, consideramos que un primer paso está en realizar un acercamiento acerca de cuáles son y qué sentidos tienen las representaciones sociales de los jóvenes, para el caso que nos ocupa, las relacionadas con lo estético.

Nos centramos en la red social, específicamente Facebook, porque se considera que las nuevas generaciones tienen una especial conexión con las redes digitales, provistas de gran 
cantidad de cargas simbólicas que se desprenden de tendencias más bien globalizadas, presentes en la música, la moda, la pertenencia a subculturas urbanas, entre otras alternativas de identificación juvenil (Rubio, 2010). Gran parte de los significados que circulan en la red, estarían delimitados por unas posturas frente al desarrollo que privilegian el crecimiento económico por encima de otros factores importantes en la vida humana, como por ejemplo el cuidado de sí mismos, de los otros y del entorno. Más bien, los mercados intentan instaurar unos modelos de vida que se han ido instaurando a través de los discursos que aparecen en buena medida en la red.

Se considera que si se realiza un acercamiento acerca de cómo se configuran ciertas representaciones sociales, se podría cuestionar más adelante incluso cómo los modelos comunicativos que intervienen en el modelamiento de esas representaciones, podrían ser replanteados para lograr trasformaciones reales en lo social, aspecto que se conecta con algunos de los intereses investigativos de la Maestría cursada. Frente a lo anterior, Gumusio (2004) y Servaes (2000) proponen que debe existir un tránsito desde los anteriores modelos de comunicación, que van desde el difusionismo-el cual está claramente conectado con las políticas de desarrollo etnocentristas de las potencias-a otra de tipo participativo y alternativo, en donde sean los ciudadanos quienes puedan intervenir en un proceso comunicativo que de realmente un papel protagónico a la comunidad. Se esperaría que los jóvenes como sujetos activos, logren no solo deconstruir esos modelos estéticos que han instaurado las hegemonías, sino que sean capaces de proponer formas de comunicar sus ideas, experiencias y motivaciones a partir de formas alternativas a las convencionales y que den cuenta de un accionar participativo, en donde se conciba a la comunicación como a un derecho en donde la comunidad debe tomar parte. 
Lo anterior se justifica al interior de la Maestría en Comunicación, Desarrollo y Cambio social, porque consideramos que las representaciones sociales de los jóvenes acerca de la estética, dan cuenta de algunos de los entramados simbólicos que se han venido construyendo desde medio cultural y es papel del investigador en el campo de la comunicación, tratar de encontrar y analizar qué narrativas están sustentando ciertas representaciones y bajo qué discursos lo están haciendo. Encontrar esas narrativas (Alexander,2000) permitiría que en nuevas investigaciones se llegue a cuestionar bajo qué perspectivas del desarrollo y la comunicación están fundamentados esos discursos, para poder luego replantearlos. Lo anterior podría ampliar la reflexión y discusión sobre qué otras posibilidades comunicativas tienen la imagen y cómo podrían estas aprovecharse para crear cambios sociales significativos, por ejemplo, en la forma en que los jóvenes interactúan con las redes sociales. Campo de investigación que queda abierto para otros trabajos que se interesen en jóvenes y redes sociales.

Producto del mencionado contexto, se plantea como interrogante central de esta investigación ¿cómo comprender los sentidos de las representaciones sociales de jóvenes (entre los 14 y 17 años, de grado octavo de la jornada mañana y pertenecientes al colegio Fernando González Ochoa de la localidad de Usme) acerca de la estética, específicamente a partir de los significados que dan a los indicadores corporales ( como ropa, accesorios, gestos, entre otros) que muestran en sus fotos de perfil en Facebook? El anterior cuestionamiento surge para tratar de entender cómo el contexto cultural y los consumos e industrias culturales, podrían intervenir no solo en la configuración de dichas representaciones, sino en las manifestaciones corporales que los jóvenes presentan en sus perfiles. 
La atención se centra en los significados que dan los jóvenes a los indicadores corporales que muestran en sus fotos de perfil tales como: posturas, gestos, ropa, accesorios entre otros, porque se considera que es a partir de su corporeidad y de la relación con ciertos objetos, como los jóvenes expresan más las representaciones que tienen de la estética.

Lo corporal está vinculado en esta investigación con lo cultural, lo que nos lleva a pensar que, en una época de industrias culturales y de múltiples consumos, las expresiones corporales mostradas a través de la foto de perfil, pueden proporcionarnos un foco de análisis sobre las representaciones de los jóvenes frente a la estética. No se está diciendo que la ropa, accesorios y posturas corporales sean constitutivas de las representaciones sociales como tal. Se escogieron estos elementos con el fin de focalizar la investigación, sin el ánimo de afirmar que el análisis sobre las representaciones sociales sobre lo estético, se agote en el análisis de dichos indicadores corporales.

Profundizar en al análisis acerca de cómo las nuevas generaciones están estructurando sus representaciones sobre la estética y cómo lo proyectan en espacios públicos como Facebook, brinda la posibilidad no solo de ampliar la comprensión del fenómeno que nos ocupa, sino que abre la perspectiva para pensar en qué otro tipo de estéticas podrían empezar a visibilizarse, a despecho de las que actualmente son socialmente más reconocidas.

La investigación fue realizada con jóvenes que oscilan entre los 14 y 17 años, pertenecientes al Colegio Distrital Fernando González Ochoa de la localidad de Usme en Bogotá Colombia. Se trabajó con 30 estudiantes, 15 de género masculino y 15 femenino 
de grado octavo de bachillerato. Las condiciones económicas de los jóvenes que participaron en este estudio y de sus familias, corresponden a las de un estrato 1 y 2 en Bogotá. Los jóvenes se encuentran atravesados por varias problemáticas sociales que viven a diario en su entono. Algunas de ellas son, por ejemplo, ser jóvenes cuyos padres en su gran mayoría tienen trabajos que les demandan bastante tiempo. Lo que produce que la atención que le dedican a sus hijos no sea suficiente. Adicional a ello, están constantemente expuestos a la violencia que se padece en la localidad de Usme. Además, pertenecen a familias en donde en muchos casos se presenta violencia intrafamiliar, principalmente del género masculino al femenino.

Dichos jóvenes pertenecen a un entorno que los hace hasta cierto punto vulnerables, debido a la escasez de recursos económicos y al ambiente violento en el que se desenvuelven (Secretarias de Salud y de Ambiente de la Alcaldía Mayor de Bogotá,2009; Observatorio De Desarrollo Económico, 2015). Esta situación se recrudece si tenemos en cuenta que gran parte de ellos, pertenecen a familias disfuncionales, en donde el joven vive con solo uno de sus padres, con los abuelos o con algún familiar, quienes usualmente tienen un bajo nivel de formación académica.

La localidad de Usme, y específicamente el barrio Virrey al cual pertenecen la mayoría los jóvenes, está asolada frecuentemente por el pandillismo, delincuencia y drogadicción que se ha ido incrementando en este contexto (Secretarias de Salud y de Ambiente de la (Alcaldía Mayor de Bogotá ,2009; Observatorio De Desarrollo Económico, 2015). Lo que se puede corroborar con los orientadores de la institución educativa a la que pertenecen los jóvenes y con los testimonios narrados por ellos mismos. 
Pese a las condiciones económicas desfavorables que caracterizan al entorno de estos jóvenes, la mayoría de ellos cuenta con acceso a internet, en algunos casos en sus viviendas, en la casa de un familiar, en establecimientos públicos cercanos y en el mismo colegio. Los jóvenes comentan que pasan entre tres y cuatro horas al día conectados a la red, de las cuales por lo menos la mitad la dedican a interactuar con otros en las redes sociales, a retocar o mejorar sus perfiles, entre otras actividades que permiten plataformas como Facebook. Actividades que, frecuentemente, realizan sin la asesoría o acompañamiento de un adulto, debido a las condiciones referidas anteriormente. Lo que permite que el joven pueda dedicar un tiempo casi ilimitado no solo a navegar por internet, sino a ver televisión, siendo interactuar en las redes sociales uno de los entretenimientos más recurrentes entre ellos, descuidando en algunas ocasiones sus compromisos académicos, personales y familiares.

Gran parte de los jóvenes de la muestra indicaron en el sondeo previo que pasan largas horas adecuando sus perfiles en las redes sociales, dado que consideran que es importante verse bien en las fotos que publican en este espacio, pues el no hacerlo, puede tener consecuencias negativas para su imagen frente a los demás, tales como falta de reconocimiento y aislamiento social. Adecuar sus fotos de perfil se ha ido convirtiendo en una de las actividades más comunes entre los jóvenes de la muestra, quienes buscan por lo general que su imagen personal sea reconocida como atractiva y que esto les permita tener una mayor interacción con otros jóvenes, tanto dentro como fuera de la plataforma. La mayoría de ellos afirma que les parece importante quedar bien es sus fotos de perfil y se esfuerzan para que esto ocurra a través del uso de diferentes aplicaciones filtros y accesorios virtuales y no virtuales que les permitan lograr este objetivo. 


\subsection{Preguntas orientadoras}

- ¿Cuáles son las representaciones sociales de la estética que tienen los jóvenes manifestados a partir los significados que dan a los indicadores corporales que muestran en sus fotos de perfil en Facebook?

- ¿Cómo podrían describirse las representaciones sociales los jóvenes (grado octavo del colegio Fernando González Ochoa de la localidad de Usme) acerca de la estética, manifestadas a partir de los significados que dan a los indicadores corporales que muestran en sus fotos de perfil en Facebook?

- ¿Qué connotaciones culturales tienen los elementos que componen a las representaciones sociales de los jóvenes (de grado octavo del colegio Fernando González Ochoa de la localidad de Usme) acerca de la estética, manifestadas a partir de los significados que dan a los indicadores corporales que muestran en sus fotos de perfil en Facebook,

\subsection{Objetivo general}

Comprender los sentidos de las representaciones sociales de los jóvenes (entre los 14 y 17 años, de grado octavo de la jornada mañana y pertenecientes al colegio Fernando González 
Ochoa de la localidad de Usme) acerca de la estética, manifestadas a partir de los significados que dan a los indicadores corporales que muestran en sus fotos de perfil en Facebook.

\subsection{Objetivos específicos}

1. Identificar las representaciones sociales de la estética que tienen los jóvenes (entre los 14 y 17 años, de grado octavo de la jornada mañana y pertenecientes al colegio Fernando González Ochoa de la localidad de Usme) manifestadas a partir los significados que dan a los indicadores corporales que muestran en sus fotos de perfil en Facebook.

2. Describir las representaciones sociales de la estética que tienen los jóvenes (entre los 14 y 17 años, de grado octavo de la jornada mañana y pertenecientes al colegio Fernando González Ochoa de la localidad de Usme) manifestadas a partir los significados que dan a los indicadores corporales que muestran en sus fotos de perfil en Facebook.

3. Analizar las representaciones sociales de la estética que tienen los jóvenes (entre los 14 y 17 años, de grado octavo de la jornada mañana y pertenecientes al colegio Fernando González Ochoa de la localidad de Usme) manifestadas a partir los significados que dan a los indicadores corporales que muestran en sus fotos de perfil en Facebook. 


\section{Capítulo II. Antecedentes de investigación}

Es preciso aclarar antes de iniciar este apartado, que aquellos estudios que fueron hallados en la revisión están conectados con la forma en que los jóvenes se muestran a sí mismos a través de las redes sociales virtuales y no específicamente en las representaciones sociales que tienen de la estética, dado que fueron los trabajos más relacionados con el tema abordado en este estudio que se pudieron encontrar, sin decir con ello que no existan otros a los que no se haya accedido. No obstante, aquellos que se consultaron sí contienen una preocupación investigativa por el tema de la apariencia y de las maneras en que los jóvenes adecúan sus fotos de perfil de acuerdo a ciertos ideales de belleza. Algunos de los trabajos revisados, se centran por ejemplo en la importancia que le dan los jóvenes a tener una apariencia atractiva; otros mencionan cómo para el joven es importante manejar un tipo de corporeidad acorde con las exigencias de su grupo de pares, etc.

Empezaremos nuestro recorrido de revisión de antecedentes con un trabajo titulado: Desde el muro: una mirada a los discursos proyectados por el cuerpo en Facebook. Allí Chaparro, Echeverry, Arévalo (2014) se concentraron en las representaciones de un grupo de jóvenes universitarios de la ciudad de Buenos Aires, específicamente en relación con el cuerpo. Para llevar a cabo este estudio, los investigadores tomaron como sujetos de la investigación a algunos estudiantes del programa de la Licenciatura en Educación Física y Deportes de la Universidad de los Llanos, ubicada en la Plata en Argentina. Se partió de la idea de que, para los jóvenes, aquello que se muestra, por ejemplo, en una foto de perfil, da una indicación clara de lo que desean que los demás reconozcan en ellos. Es decir, la 
imagen que se publica como perfil en la red social, específicamente en Facebook, correspondería con un afán del joven por personificar su identidad y posicionarse en el mundo de una manera específica Echeverry, Arévalo (2014).

Adicional a ello, Chaparro, Echeverry, Arévalo (2014) señalan que, en la red social, el concepto mismo de privacidad ha ido transformándose, dado que aquello que anteriormente se consideraba como privado, ahora hace parte de lo que se muestra, con el afán de ser reconocido por otros. Ahora bien, los autores afirman que ese querer ser identificados en la red social virtual, se da mayoritariamente a través de la imagen, y, muy específicamente, desde de la forma en que se presenta lo corporal en esas imágenes. Es más, señalan cómo el cuerpo es presentado por la mayoría de los jóvenes en Facebook desde la necesidad de "verse bien", es decir mostrar las situaciones en donde estarían en condiciones consideradas socialmente agradables, en oposición a otras como el temor, la tristeza o la enfermedad. De hecho, cuando los jóvenes se refieren a este tipo de situaciones no tan agradables, se tienden a usar más caricaturas, imágenes o frases breves (Chaparro, Echeverry, Arévalo, 2014).

En este estudio se señala cómo el diseño mismo de la plataforma de Facebook hace que las posibilidades para interactuar con una publicación se limiten mucho a expresar el agrado que una situación o imagen puede suscitar. Un claro ejemplo de ello estaría en que el usuario puede dar "me gusta" a una publicación, pero siempre en relación con aquello que se considera agradable. De ahí que se proponga que una plataforma virtual como Facebook, está redefiniendo los sentidos sociales en que nos desenvolvemos, dando relevancia a destacar solamente lo que parece atractivo a los ojos de muchos. Y es que la 
opinión que tengan los demás de los jóvenes, viene a ser un factor preponderante para los ellos (Chaparro, Echeverry, Arévalo, 2014).

Allí el cuerpo, entendido por los autores como una construcción simbólica, se convierte en el portador de todos los elementos de distinción que permiten al joven sentirse reconocido. Tales elementos distintivos se conectan con la moda, la relación con alguna tendencia en cualquier campo y con el poder adquisitivo (Chaparro, Echeverry, Arévalo, 2014).

En este trabajo lo corporal toma una dimensión representativa sobre ese ser que se quiere proyectar hacia los demás. Quién se es, pasa primero por aquello que el cuerpo muestra, las actividades que se hacen y los signos que se consumen. Se empieza a ser, en la medida en que los otros me observan y así se reafirma la identidad (Chaparro, Echeverry, Arévalo, 2014). Por supuesto que esos signos que se están conectando actualmente con bienestar, estarían atravesados por los actuales discursos económicos, en donde la calidad de la existencia se mide en términos de cuánto poder se tiene para consumir, y, sobre todo, qué tanto se puede evidenciar esto a través de la imagen.

Este trabajo aporta una perspectiva de análisis del cuerpo y lo corporal como un constructo social y simbólico muy conectado con el contexto en que se desenvuelven los jóvenes. Además, contribuye con la idea de que las imágenes en donde lo corporal toma relevancia y que se publican en espacios como las redes sociales, se convierten en artefactos simbólicos (Chaparro, Echeverry, Arévalo, 2014). Estos llevarían en sí las cargas de sentido que proveen discursos tan en boga como el que asocia el bienestar y la felicidad humana con la capacidad para consumir. 
Lo anterior permite pensar en cómo las representaciones sociales acerca de la estética que tengan los jóvenes en sus fotos de perfil en Facebook, pueden estar conectadas con los sentidos que se construyen desde ámbitos del orden social y cultural.

En otro estudio realizado por Almansa, Fonseca, Castillo (2013) relacionado con Facebook y jóvenes se analizaron 100 perfiles de Facebook de adolescentes entre 12 y 15 años de edad de dos colegios, uno situado en Colombia y el otro en España. Su interés se centró en reconocer cómo los contenidos que los adolescentes publican en sus fotos de perfil, responden a procesos de identidad que se materializan a partir de la imagen. Para hacerlo, utilizaron técnicas como la entrevista en profundidad (cualitativa) y un análisis de contenido de tipo cuantitativo.

Algunos de los hallazgos de este trabajo apuntaron a que los individuos son capaces de construir una imagen de sí ante los demás (Almansa et al., 2013) que se manifestaría primordialmente en el tipo de imágenes que publican en las redes sociales. A partir de estas, se buscaría ante todo la aceptación del adolescente por sus pares tanto en el plano real como virtual.

De hecho, en la investigación referenciada, se evidencia cómo a partir de las redes sociales se realizan procesos de negociación de la propia identidad, en los que la imagen juega un papel preponderante. Allí, las interacciones que se dan desde la red no son pasivas; contrario a ello, los usuarios participarían activamente en la creación de nuevo contenido virtual. Esto es interesante en tanto no se parte de que los usuarios simplemente recepcionen una serie de imágenes de perfil, sino que existe un proceso de creación de 
sentido, en donde tanto quien publica como el que lee las fotografías, pone sobre la mesa sus propias representaciones sociales.

Algunos de los hallazgos que resultaron a partir de dicha investigación fueron que, para los adolescentes estudiados, su perfil tiene una amplia conexión con la forma en que administran su personalidad; es decir, que el acto de creación del perfil en Facebook y asignarle un contenido, es similar a la creación de un ser en un entorno digital Almansa et al., (2013).

En este estudio se afirma que, en los perfiles de Facebook, los adolescentes no se presentan necesariamente como ellos son, sino como quisieran ser, lo cual trae para ellos una connotación en la forma en que se desenvuelven en su vida social, tanto dentro como fuera de la plataforma (Almansa et al., 2013)

Para Almansa et al., (2013) incluso el nombre que adopta el adolescente en su perfil estaría fuertemente conectado con su identidad; de la misma manera añaden que la apariencia juega un papel central en esos procesos de interacción, por lo cual los adolescentes se esmeran mucho en preparar una foto que corresponda con sus expectativas:

La imagen que los adolescentes publican para ser identificados en la red social es uno de los elementos a los que dedican mayor tiempo: piensan su imagen, la diseñan, la crean, la producen, la editan...la reeditan. Sin embargo, ellos construyen su imagen en soledad. Al observar las "fotos de perfil" de los cien perfiles de Facebook estudiados, nos encontramos que la mayoría aparecen solos. Además, la fotografía ha sido hecha por ellos mismos mediante un espejo. (Almansa et al., 2013, p. 130) 
Dicha imagen cobra gran importancia, no solamente en el estudio citado, sino en este, en tanto es a partir de ella de donde se suscitan los análisis sobre las representaciones de los jóvenes con los que trabajamos. Dicho estudio nos da un punto de partida porque evidencia cómo los jóvenes trabajan la imagen que han de presentar en su perfil y lo hacen a partir del uso de signos, gestos que muestran y que se hacen visibles desde su corporeidad, por lo menos la mayor parte de las veces. Y lo hacen, según Almansa et al., (2013), desde la imagen de sí mismos que desean proyectar a los demás. Por supuesto en este trabajo no nos centramos en el tema de la identidad, pero sí nos enriquece este análisis porque nos ayuda a comprender cómo la imagen que quieren proyectar los jóvenes en sus fotografías, se conecta con las amalgamas de sentido que crean y perpetúan ciertas representaciones sociales, siendo las de la estética las que nos interesan en ese lugar.

Otro estudio consultado fue el realizado por Torres, Iglesias (2011) en el que se profundiza en cómo ser visible significa para muchos jóvenes estar en el muro; es decir, ser visible para otros en las redes sociales. Este trabajo analiza las concepciones que tienen los jóvenes sobre Facebook, particularmente si lo consideran como un espacio social, en donde se pueden generar ciertas interacciones que hasta hace tiempo estaban reservadas para lo público.

En este trabajo se argumenta que en Facebook los jóvenes tienden a realizar un doble proceso, por un lado, se muestran a los demás como quieren ser reconocidos, por el otro, tienen acceso a la información que otros les comparten Torres, Iglesias (2011). Lo interesante para este estudio es notar cómo Facebook se ha ido identificando como 
un espacio de encuentro, pero también de estructuración del yo, en tanto el usuario tiene la posibilidad de crear una versión digital de sí mismo desde la que puede ser identificado. Esta versión de sí mismo estaría en conexión con los gustos, modo de ser y estar en el mundo del joven. Retomamos este trabajo como antecedente, porque también nos interesa revisar cómo esas construcciones del yo que hacen los jóvenes y que plasman a partir de sus fotos de perfil, pueden generar y mantener ciertas representaciones sociales sobre la estética.

Otro estudio que conecta a jóvenes y Facebook, fue el realizado por Dillon (2013), quien analizó en un trabajo titulado: Miradas de adolescentes argentinos sobre la intimidad en Facebook, cómo los jóvenes perciben la interacción que mantienen en Facebook con sus contactos y cómo esta se vincula con la intimidad tanto propia como la de sus amigos. Para hacerlo, hizo una investigación cualitativa basada en el análisis de algunas entrevistas en profundidad realizadas a jóvenes de diferentes condiciones económicas. Dicha investigación se centró además en analizar los usos que los adolescentes argentinos hacen de la plataforma en cuestión y las representaciones que surgen desde la interacción con los demás.

Algunas de las conclusiones a las que llegó el autor tienen que ver con que, a pesar de que en Facebook sí se muestran muchas imágenes que se conectan con la vida privada de los jóvenes, esto no significa que dejen de existir ciertas situaciones que son consideradas inadecuadas para ser mostradas a otros, por ejemplo, fotos con la pareja en situaciones comprometedoras o cuando se está triste. Es decir, los jóvenes evitarían mostrar fotos de sí mismos en donde se está en una situación considerada desagradable a nivel social y cultural. 
Es más, las imágenes en donde el joven se encuentra triste no son las más usuales; contrario a ello, el autor señala que las imágenes que muestran los sujetos de investigación, contienen usualmente sonrisas y momentos triviales en donde se proyecta a los demás cierto bienestar (Dillon, 2013).

Adicional a ello, pero no menos importante, es que este trabajo, pese a no estar dedicado a las representaciones sobre estética en fotos de perfil en Facebook, sí evidencia cómo los jóvenes y su corporeidad suelen aparecer en las fotos que publican, demostrando que están o han estado en situaciones socialmente identificadas como deseables, idea que se retomará y profundizará más adelante.

Un estudio más específico sobre adolescentes y jóvenes, en relación con imágenes de perfil, corporalidades y autopresentación es el realizado por Basile y Linne (2014) en un texto titulado: Performances de autopresentación a través de fotografías digitales. El caso de los adolescentes de sectores populares en Facebook. Estudio realizado en Buenos Aires Argentina. Este trabajo parte de la hipótesis de que los adolescentes utilizan herramientas como la plataforma de Facebook, para auto presentarse ante los demás, más específicamente, ante sus pares etarios. La población elegida por los investigadores se ubica en los sectores populares, característica en la que se insiste en el documento. Para realizar el trabajo, eligieron una muestra de fotos de adolescentes, a las que lograron acceder gracias a la creación de un perfil ad hoc. También recibieron la ayuda de algunos informantes que accedieron a colaborar con el estudio y que pertenecían a ciertas micro comunidades juveniles.

Algunos de los aportes más significativos para esta investigación tienen que ver con la relación que establecen los adolescentes con las imágenes al interior de la red social. Los 
autores afirman que los adolescentes tienden a presentarse a sí mismos mostrando y monitoreando las imágenes de sí mismos que publican en la red social. Este proceso es intencional y busca, concretamente, el reconocimiento por parte de sus contactos, especialmente el de sus contemporáneos (Basile y Linne, 2014). Lo que quiere decir que la forma en que se presentan a los otros es altamente selectiva. De ahí que la imagen seleccionada, incluidos los retoques que frecuentemente se le hacen a través de programas especializados para tal fin, buscan dar la mejor versión del adolescente en relación con ciertos cánones de belleza y estatus social que aparecen frecuentemente en los medios masivos. Dichos cánones se retoman como referentes al crear las imágenes y fotos de perfil que se publicarán en Facebook (Basile y Linne,2014).

De los elementos más interesantes de este trabajo para el nuestro está el que, la mayoría de las veces, la forma de auto presentarse que tienen los adolescentes es mostrándose a sí mismos, exhibiendo ciertas posturas, accesorios, gestos dependiendo de la situación e intención que se tenga con una foto. Basile y Linne (2014) identificaron tres tipos de fotos de perfil como producto de su trabajo. La primera es la auto foto, en donde el adolescente sale casi siempre solo, realizando algún gesto o postura corporal en algún espacio, por lo general muy privado, como el baño o su habitación. El segundo tipo de foto la denominaron fotobook. En ella, los adolescentes tienden a realizar poses y gestos, frecuentemente frente a un espejo que funciona en este caso como espectador, que les permite predecir las reacciones de sus pares. Los autores señalan que estos dos tipos de fotos se dan más entre las mujeres, aunque muchos hombres han tendido a usarlas también. El tercer tipo de fotos que se identificaron son las que incluyen al grupo de pares. En las dos primeras, los componentes centrales son los identitarios, lúdicos y sexuales; mientras 
que, en la última, lo erótico aparece, pero en conexión con la pertenencia a un grupo. Para los autores, esta última categoría se divide entre fotos diurnas y fotos nocturnas. En las diurnas se presentarían momentos más cotidianos y no se da tanta relevancia a las poses corporales. Por su parte, en las fotos entre pares nocturnas, se da más importancia a mostrarse a sí mismos realizando actividades que están fuera del control, por ejemplo, de los padres. Tales actividades pueden ser fiestas $\mathrm{u}$ encuentros en donde el consumo de alcohol y/o drogas parece ser considerado como un factor positivo y que brinda reconocimiento social (Basile y Linne,2014). Esta investigación de carácter exploratorio nos sirve como antecedente en tanto permite identificar algunos tipos de fotos de perfil que publican los jóvenes señalados por los autores, que están conectados con la corporalidad y con la forma en que los jóvenes se presentan ante los demás, en mayor medida, a través de mostrarse a sí mismos de diferentes formas, posturas y exhibiendo ciertos artículos. Lo que se hace, además, de manera intencionada y bajo la espera de una retroalimentación que, por lo menos en Facebook, ocurre por lo general a través de los me gusta, comentarios, memes, emoticones, etc.

La tipología de las fotos publicadas por adolescentes en Facebook que nos ofrece Basile y Linne (2014) nos sirve como un referente de análisis importante para analizar las representaciones sociales sobre la estética en fotos de perfil en Facebook, porque nos ayuda a comprender las tendencias juveniles que existen actualmente sobre lo que se considera bello o agradable a la hora de publicar una foto de perfil en esta red social.

Finalmente retomo el capítulo de libro de Bonnaci (2013) titulado: Los jóvenes de perfil: una aproximación a las representaciones corporales de adolescentes y jóvenes usuarios de Facebook. En este trabajo el autor se centra en analizar qué importancia 
cobran las imágenes cuando los adolescentes se presentan a sí mismos a partir de las redes sociales, focalizándose para ello en la presencia del cuerpo y de las significaciones que este adquiere en este espacio virtual. Para hacerlo, recurrió a un corpus de entrevistas semiestructuradas a jóvenes del área metropolitana de Buenos Aires. También se observaron y analizaron diferentes perfiles de jóvenes presentes en redes sociales, entre los 16 y 19 años. Ambos corpus estaban centrados en tratar de encontrar los significados que tiene la representación del cuerpo en la red social, específicamente Facebook.

Como resultado de este trabajo, se presentan algunas ideas. En primer lugar, el componente lúdico cobra una especial importancia en la interacción que el adolescente realiza con la red social, lo cual se evidencia en las formas y estilos en que desarrolla su sociabilidad. El adolescente interactúa en la red social de manera frecuente y, para hacerlo, juega con su propia imagen, la cual comparte con los demás, con miras a auto identificarse y buscar el reconocimiento de los otros (Bonacci, 2013). Ahora bien, esa imagen que pone a disposición de los demás, representa su mejor cara; es decir aquellas posturas, gestos y demás elementos expresivos que socialmente son aprobados, en este caso especialmente por sus pares. La idea de la cara y de lo que implica mostrar una cara socialmente reconocida es retomada por Bonnaci de Goffman (1970). Allí, de lo que se trata es de que a la hora de mostrar una cara a los demás, se tiene en cuenta la capacidad que el sujeto tiene de actuar, de acuerdo a elementos que pone en escena cuando interactúa con otros, por ejemplo: el estatus socioeconómico, la micro cultura a la que pertenece. Los elementos que el adolescente muestra a través de las imágenes de perfil, se convierten entonces en el referente o la cara (Goffman, 1970) que los demás apreciarán y valorarán de acuerdo a los 
patrones socialmente definidos y a cómo se ha mostrado el sujeto a través de sus diferentes interacciones.

Ahora, la forma en que el adolescente se muestra en la red social y las interacciones que logra, están fuertemente relacionadas con las representaciones corporales que se tienen sobre sí mismo y los demás. Es decir, que la manera en que se crea y gestiona un perfil en Facebook, los gestos, posturas y preferencias que representa, dan cuenta de los mundos sociales a los que pertenecen los jóvenes (Bonacci, 2013).

Adicional a ello, el autor relaciona los tipos de representaciones corporales que evidencian los adolescentes en sus fotos de perfil, con las micro culturas a las que éstos pertenecen. Identifica, particularmente, dos tipos de fotografías. La primera, incluye un estilo personal, en donde el foco de atención está en el creador del perfil, quien se erige como figura central. En ocasiones, este estilo da cuenta de los gustos, preferencias y adscripciones a grupos, los cuales cobran un papel relevante en la imagen. Un segundo estilo es categorizado por Bonacci (2013) como más discreto, en donde se muestran algunas expresiones faciales, pero se tiene cuidado con la exhibición del resto del cuerpo de la persona (Bonacci, 2013). Se señala que, en este tipo de fotografías, se pueden manejar dos tendencias; una más exhibicionista, en donde se ponen en juego ciertos fetiches de la cultura erótica contemporánea; otra discreta, en donde la manera de presentar lo corporal es menos espectacular, es decir menos llamativa y sensual (Bonacci. 2013).

Este estudio nos brinda la posibilidad de observar cómo la sociabilidad y las micro culturas juveniles se relacionan con algunos de los estilos que pueden manifestar los jóvenes en sus fotos de perfil en Facebook, específicamente en las que se pone en juego 
ciertas formas de presentarse a sí mismos. No obstante, con esta investigación se pretende profundizar un poco más no solo en los estilos de fotos que aparecen publicadas por los jóvenes en sus perfiles, sino en las representaciones que ellos tienen en sí sobre la estética en dichas fotos. 


\section{Capítulo III. Aproximación teórica}

\subsection{Acerca de Facebook}

Facebook es una de las redes sociales virtuales más utilizadas actualmente para compartir información, intercambiar mensajes, subir y ver fotografías, videos, publicar y leer comentarios, crear grupos de interés, jugar en línea, entre otras actividades que permite la plataforma. Entendiendo por red social a la reunión de personas conocidas o no entre ellas, que interactúan entre sí retroalimentando al grupo al cual están conectadas (Aguirre, 2011). La red social es ante todo una estructura que se conforma a través de una serie de relaciones, en donde se dan intercambios entre los actores que las componen. Dicha estructura contiene unas particulares normas y pautas que deben seguir sus integrantes y, que, de alguna manera, condicionan la conducta que pueden o no observar allí los usuarios (Aguirre 2011).

Cuando nos referimos particularmente a la red social virtual, estamos hablando de ese tipo de espacios virtuales que aparecieron con el advenimiento de la web 2.0, que implicaban una más amplia participación de los usuarios como consumidores y creadores de contenidos (Portillo, 2016). En este contexto, se amplió el campo de interacción entre las personas, quienes ahora tienen la posibilidad de adscribirse a grupos y tener una interacción fluida a través de la web. Al interior de estas redes, los individuos hacen parte de grupos en donde lo frecuente es que se tengan algunas afinidades, que pueden estar vinculadas a cualquier tipo de actividad o predilección (Portillo. 2016). Por ejemplo, 
existen redes sociales conectadas con entretenimiento, causas sociales, intelectuales, deportivas y otras cuyo contenido es más bien variado, como ocurre con Facebook.

Facebook es una red social virtual creada por Mark Elliot Zuckerberg, Andrew McCollum y Eduardo Saverin en 2004, cuando eran estudiantes de la universidad de Harvard en Estados Unidos. La idea de crear esta plataforma virtual inicia como un pasatiempo, en donde se buscaba generar un medio de comunicación entre los miembros de la universidad. Comunicarse por este medio se incrementó cuando los universitarios agregados a este sitio virtual, comenzaron a comentar las fotos de otros compañeros y hasta a darles puntos, de acuerdo a qué tan atractivas les parecieran sus fotos.

Aquello que hacía tan atractiva a esta nueva plataforma, antes llamada The Facebook, era que no solo guardaba la información personal de los posibles consumidores, sino que además permitía que los usuarios pudieran recomendar los productos a sus propios “amigos" o contactos que tuvieran agregados.

Facebook empezó a convertirse en un mecanismo de publicidad muy eficiente, en tanto se vinculaba con las vidas personales de sus usuarios, quienes hacían evidentes sus preferencias en muchos campos. Es decir, allí se ponía al descubierto quiénes eran los clientes potenciales para ciertos tipos de productos, información de cuantiosa valía para cientos de compañías. Para López (2010), Facebook ya se había convertido en una de las redes sociales virtuales más poderosas en el mundo, contando para entonces con 500 millones de integrantes (López, 2010). Para el 2017, la misma compañía anunció que en su presentación de resultados del primer trimestre de 2017, que el número de personas que utilizan activamente la red social iba por los 1.940 millones mensualmente. 
La gran acogida de esta red social virtual podría residir en las múltiples posibilidades de contacto que brinda entre sus usuarios, quienes pueden localizar a viejos amigos o familiares, compartir fotos y comentarios. Adicional a ello, Facebook plantea en su estructura interna, unas formas específicas de relacionarnos con los demás, que van siendo dirigidas de acuerdo a los espacios y herramientas disponibles para el usuario. Se trata de una arquitectura diseñada para señalar aquello que gusta, a despecho de otras posibilidades inexistentes en dicha plataforma sobre aquello que más bien se repele (Gurevich, 2016). Ejemplo claro de lo anterior está en el botón de "me gusta", que es utilizado por los usuarios para indicar su predilección por cualquier publicación a la que haya accedido.

Lo fundamental en esta red social es la interacción. Así que entre más interacciones haya entre los usuarios, mayor parece ser el nivel de éxito de este espacio (López, 2010). Esto es así, en tanto la interacción con otros, el hecho de comentar acerca de algo que otro publicó, permite que la información publicitaria se expanda entre los usuarios, quienes, al tener algún nivel de cercanía entre sí, se convierten en portavoces por excelencia para los productos que pretende vender el mercado (López,2010).

En Facebook la cercanía con lo personal, con lo hasta hace poco se consideraba "privado", empieza a convertirse en algo que es deseable mostrar. De la misma manera, la arquitectura del sitio virtual facilita e insta a los usuarios a hacerse partícipes en la vida de los demás, como espectadores activos que producen textos que muestran hasta qué punto una publicación ha tenido impacto entre los contactos (Gurevich,2016). Para hacerlo, la plataforma cuenta con estrategias como la posibilidad de escribir un comentario, dar un "like", enviar un emoticono o imagen cargada con ciertos sentidos socialmente 
compartidos, como por ejemplo una cara feliz o un corazón, entre tantos otros que se encuentran disponibles allí.

La popularidad de esta red social virtual podría residir en las múltiples posibilidades de contacto que brinda entre sus usuarios, quienes pueden localizar a viejos amigos o familiares, compartir publicaciones que pueden ser fotos, comentarios, canciones, etc., y que van contando un relato con relación a quién es la persona que las compartió (Gurevich,2016). De hecho, en Facebook existe un espacio denominado "Biografía", en donde el usuario puede encontrar de manera organizada cronológicamente su vida desde el momento en que se registró, hasta la fecha actual. Es decir, la plataforma y su lógica interna se encargan de dirigir la atención sobre algunas publicaciones que se deberían considerar memorables y las hace aparecer por ejemplo un año después, para que el usuario las vea y, posiblemente, las comparta. En Facebook, cada usuario es el protagonista de la historia de su vida contada a través de imágenes, comentarios, estados de ánimo y, en buena medida, la interacción con los otros, que dota de sentido a los momentos que se comparten (Gurevich,2016).

Para hacer partícipes a los otros de esas experiencias personales, los usuarios cuentan con estrategias diferentes y cada vez más diversas, entre las que se encuentra publicar un video desde otros sitios virtuales como YouTube, compartir un enlace, crear contenidos con texto escrito e imágenes como los conocidos memes $\left(^{1}\right) \mathrm{y}$, muy especialmente, fotografías subidas hoy en día sobre todo desde dispositivos celulares.

\footnotetext{
${ }^{1}$ Imágenes construidas por los usuarios y que por lo general incluyen humor.
} 
Estos artefactos permiten al usuario capturar imágenes de un aquí y ahora que, en nuestros días, tiene una marcada aceptación en la red. El celular y su facilidad para estar presente en cualquier momento de la vida, hacen que cualquier imagen pueda ser compartida en cuestión de segundos. Imagen que, a su vez, puede generar una serie de reacciones que, en ocasiones, consiguen ser casi instantáneas en tanto estamos en la era de la conectividad y la inmediatez (Villi, 2010) Ahora bien, en este trabajo investigativo se indagará acerca de cómo esas imágenes, específicamente las fotos de perfil que publican los jóvenes en Facebook, pueden estar conectadas con unas representaciones sociales específicas sobre la estética. De ahí que fuera importante delimitar qué es Facebook y cuáles son algunos de los elementos importantes al interior de esta plataforma virtual

\subsection{Ser joven hoy en día}

En una investigación sobre los jóvenes y cuyo objetivo es ampliar el campo de reflexión sobre los universos de sentido en que se desenvuelven, se hace crucial realizar una contextualización teórica que nos ayude a situarnos en algunos de los conceptos que permiten profundizar en la categoría de joven. Iniciaremos este recorrido revisando algunas de las definiciones de lo que significa ser joven, así como la relación de dicha categoría con los contextos virtuales de nuestra época, teniendo en cuenta la relevancia que tienen en este trabajo las redes sociales virtuales, específicamente Facebook.

Lo joven estaría conectado con unas significaciones situadas en un contexto social y cultural de acuerdo a la época o momento histórico en el que estemos ubicados Reguillo (2007). Es decir, lejos de pensar que lo joven está ceñido solamente por la edad, se 
propone que lo que define qué es considerado juvenil, está dado por unas condiciones culturales delimitadas (Reguillo ,2007). Lo anterior no significa que la edad deje de ser un indicador con el que podamos relacionar al joven. Se dice que este indicador por sí solo se quedaría corto si tratamos de comprender cómo se está entendiendo la categoría en cuestión en la actualidad.

Juventud se comprende en este lugar como una multiplicidad de situaciones y signos que, en una sociedad determinada, están conectados con esta etapa de la vida (Margulis y Urresti, 1996). Es decir, qué se entiende por joven va a depender del tipo de cultura y de una forma específica de comprender las relaciones sociales entre sus miembros. De ahí que existan múltiples formas de ser joven, que obedecen a factores que se ligan con lo cultural, social y, en buena medida, lo económico. No es lo mismo ser un joven de clase media o alta, que serlo en las clases populares. Lo anterior, debido a que existen unos signos que se conectan con la juventud, tales como: menores responsabilidades, acceso a ciertos estilos de ropa y consumos culturales, a los que no todos los miembros de una sociedad pueden suscribirse con la misma facilidad (Margulis y Urresti, 1996).

Según Reguillo (2007), la categoría de joven también tiene en su origen un trasfondo económico. Surge durante la posguerra. Allí con el advenimiento de la industria cultural, empieza a existir un mercado que tiene a los jóvenes como a sus consumidores por excelencia. En este contexto, ciertos signos identitarios empiezan a ser rápidamente internacionalizados. Dichos signos se materializan según la autora en modos de vestir, en la música que se escucha, los objetos que se consideran significativos, los estilos y modas que se generalizan. Es decir, aparece en el escenario local y global una estética que se 
conecta con las formas reconocidas de ser o identificarse como joven Reguillo (2007), que varía en relación con los grupos o tendencias que se han generalizado. Con frecuencia a través de los medios.

Reguillo (2007), Margulis y Urresti (1996) coinciden en que, para alcanzar una mayor comprensión de lo que significa ser joven, no basta con analizar esta categoría como si estuviera por fuera del contexto al que pertenece. Es decir, pensar al joven implica conectarlo con ese mundo simbólico al que hace parte desde su cultura y estructura social. Las implicaciones de ello tienen que ver con que aquellos signos, experiencias, formas de percibir el tiempo y la vida del joven, están marcados por el entorno del cual hacen parte (Margulis y Urresti, 1996); es decir son producto de este. De ahí que lo que distingue a los jóvenes de los demás, no es únicamente la edad, sino algunos esquemas de sentido compartidos que están vinculados con los aspectos culturales, sociales y económicos a los que están expuestos (Margulis y Urresti, 1996).

Dichos aspectos van estableciendo unos valores simbólicos que se asocian con las estéticas dominantes (Margulis y Urresti, 2008). Lo que significa que aquello que se considera bello o agradable, pasa por el tratamiento que las industrias culturales dan a esos objetos-signos que son convertidos en mercancías (Margulis y Urresti, 1996). Para los autores, esos signos se estetitizan al punto de impactar ampliamente los discursos sociales que se normalizan o se conectan con los imaginarios de lo que implica ser joven. Tales signos se materializan por ejemplo en la vestimenta, en las formas de expresar la corporeidad y, en general, en todo cuanto se considera deseable (Margulis y Urresti, 1996). 
Lo anterior no implica que, pese a las intenciones globalizadoras del mercado, todas las formas de ser joven sean homogéneas. Pese a esa tendencia homogeneizadora del mercado, en el mundo social aparecen formas alternativas de ser joven que tienen la capacidad de resignificar esos signos-mercancías que tienen los jóvenes a disposición por doquier. Reguillo (2007) menciona cómo al hablar de los jóvenes nos enfrentamos a una categoría que dista mucho de poder ser encapsulada en una conceptualización cerrada. Contrario a ello, afirma que para reflexionar acerca de los jóvenes y de cómo están estructurados sus esquemas de sentido, es necesario aceptar que son agentes sociales, capaces de movilizar, resignificar y construir formas alternativas de concebir el orden social. De ahí que critique aquellas posturas que lo identifican con un apático político sin propuestas o con un ser que debe transitar por esa etapa peligrosa e inconsistente que es la juventud, para llegar a ser el adulto que la sociedad espera que sea, especialmente desde el punto de vista productivo Reguillo (2007).

El joven aparece como un sujeto activo, difícilmente etiquetable en una categoría fija e inamovible. Por supuesto, se asume que los jóvenes sí están en buena medida permeados por los horizontes culturales, sociales y económicos del contexto, pero eso no significa que dejen de resignificar o actualizar de manera subjetiva esos signos-mercancías que les ofrece el medio (Reguillo ,2008). De no ser así, algunos intersticios, resistencias y tensiones entre lo que aparece en las industrias culturales como deseable y algunas posiciones juveniles serían inexistentes.

De ahí que en esta investigación se asuma al joven como un sujeto capaz de movilizar, de crear sus propias perspectivas, sin desconocer los influjos que sobre éstas tienen los 
poderes provenientes de la cultura y, muy especialmente, del mercado (Reguillo,2007). Este último tiene una repercusiclara en el tipo de estéticas que se están manejando desde lo juvenil, pero según la perspectiva de Reguillo (2007) el joven tiene un papel activo que puede generar una tensión con el orden establecido, bien sea por la coerción directa de las instituciones o por el control implícito que sobre él ejercen las industrias culturales:

Los bienes culturales no son solamente vehículos para la expresión de las identidades juveniles, sino dimensión constitutiva de ellas. La ropa, por ejemplo, cumple un papel central para reconocer a los iguales y distanciarse de los otros, se le transfiere una potencia simbólica capaz de establecer la diferencia, que una mirada superficial podría leer como homogeneidad en los cuerpos juveniles

Hoy como nunca hemos entrado en una fase acelerada de producción social de formas estéticamente masivas. El mercado apoyado por una industria publicitaria que propone patrones de identificación estética globalizada, es lo suficientemente hábil para catar y resemantizar los pequeños o grandes giros de la diferencia cultural. (Reguillo, 2007, p.81)

El mercado por supuesto tiene un impacto en el tipo de estéticas que se están manejando desde lo juvenil. Pero según la perspectiva de Reguillo (2008), el joven tiene un papel activo que puede generar una tensión con el orden establecido, bien sea por la coerción directa de las instituciones, o por el control implícito que ejercen las industrias culturales:

(...) Hay una relación múltiplemente mediada entre los imaginarios propuestos por el mercado y los modos diferenciales de apropiación, negociación y resemantización 
de estos imaginarios por parte de los jóvenes, relación a la que solo puede accederse mediante la investigación empírica. (Reguillo, 2007, p.85)

La perspectiva que asume la autora deja abierta la alternativa de que esa homogeneidad circundante pueda quedar en ocasiones en entre dicho, cuando los jóvenes empiezan a resemantizar y a subjetivizar esos esquemas simbólicos que encuentran especialmente en los medios. Es decir, los jóvenes protagonizan en muchas ocasiones, una serie de tensiones con esos órdenes dominantes, materializados en formas particulares de asumir esas estéticas que se han ido generalizando Reguillo (2007). Aspectos serán desarrollados a lo largo de este documento.

\subsubsection{El joven como agente activo.}

Aquello que se entiende por joven se ha ido transformando a través del tiempo. Una de estas concepciones lo sitúa como alguien que aún no alcanza el grado de madurez necesaria para ser persona. Muñoz (2011) señala a esta postura como una de las más reconocidas por la sociedad hasta hace poco. En esta perspectiva, el joven es un ente pasivo que recepciona la información de los medios de difusión de acuerdo a unos modelos que buscan y logran unificarlo con otros de su edad (Muñoz, 2011). Contrario a ello, en este lugar concebimos al joven como un sujeto capaz de modificar su entorno, dada su capacidad de proponer opciones de interpretación de lo que pasa en el mundo que le rodea.

De ahí que la perspectiva de Muñoz (2011) sobre joven como ese sujeto que se construye de forma activa así mismo, sea la que vamos a manejar en este trabajo. Dicha 
postura es interesante dado que le apuesta a un joven que tiene la posibilidad de crear otras múltiples formas de existencia, que plasma desde diversos espacios que, actualmente, se sitúan en la virtualidad por excelencia. El joven que nos interesa describir es, entonces, aquél que convierte su vida misma en una obra de arte (Muñoz, 2011), pues está en la capacidad de intervenir en la modelación de su entorno.

\subsubsection{Los jóvenes y lo virtual.}

Tratar de comprender lo que significa ser joven hoy en día implica entender el contexto en el cual están inscritas las generaciones más recientes. Para hacerlo, es imprescindible establecer un diálogo entre el influjo de los medios y las nuevas tecnologías de la información, con el nuevo tipo de jóvenes que están emergiendo en lo contemporáneo Reguillo (2007).

Los jóvenes en la actualidad encuentran a su disposición una serie de herramientas tecnológicas que avanzan vertiginosamente, en ocasiones más pronto de lo que son asimiladas por ellos mismos, debido al afán imperante de las lógicas del mercado por acelerar los procesos de consumo. En este contexto, la manera de concebir el tiempo y espacio también se van transformando. De acuerdo con Reguillo (2007), la perspectiva que asumen los jóvenes a la hora de leer el mundo ya no es lineal, como ocurría con las generaciones anteriores. Es decir, la lectura que ellos hacen hoy en día de los textos que hacen parte de su entorno, no se hace ya en un orden secuencial ni respondiendo a una suerte de direccionalidad predecible. Contrario a ello, se manifiesta una lógica de sentido más similar al hipertexto (Reguillo, 2007). Para la autora, esa manera hipertextual de 
relacionarse con los textos, incluida la vida misma como texto, responde a las nuevas formas de organización simbólica que se han venido gestando en la actual sociedad red.

Reguillo (2007) señala, además, cómo los jóvenes se están relacionando con el mundo al estilo videoclip, lo que implica que los procesos de producción de sentido que se llevan a cabo en la actualidad, se alejan de los postulados de la modernidad, en donde conocer se relacionaba con llevar a cabo un proceso lineal de la información. Hoy en día, un texto se conecta con otro; este, a su vez, con una imagen, que remite a un texto multimedia en donde varios lenguajes se interconectan dotando de múltiples significados a cualquier texto.

El joven de este contexto histórico ha aprendido desde niño a relacionarse con esta manera interconectada de conocer (Reguillo, 2007). Es más, las nuevas tecnologías han ido transformando no solamente la manera en que los jóvenes leen los textos o se comunican entre sí; también la forma en que se divierten, expresan sus ideas, realizan y sostienen lazos de amistad, seducen y se muestran así mismos frente a los otros (Urresti, 2008). Tener esto claro, permite ampliar la perspectiva de análisis del contexto en que emergen las representaciones sociales de los jóvenes, en especial aquellas que se vinculan con los entornos virtuales, como en el caso que nos ocupa.

Con relación al tipo de jóvenes que han aparecido en la contemporaneidad y su relación con los medios y las nuevas tecnologías, Baricco (2008) ha realizado una reflexión interesante. En primer lugar, y en consonancia con Reguillo (2007), señala cómo las formas de aproximarse a la experiencia y de generar sentido, se han transformado al punto de volver casi irreconocibles algunas prácticas e ideas que, desde la antigüedad, habían 
fundamentado aquello que conocíamos como civilización. Lo anterior desembocaría en lo que el autor denomina: mutación. Proceso que abre las puertas a los nuevos modos de producción de sentido que tendrían los bárbaros o, para efectos de este estudio, los jóvenes. Cabe aclarar que Baricco (2008) no utiliza el término "bárbaro" desde una connotación peyorativa. Más bien, propone este concepto para hacer referencia a una nueva oleada de personas que están siendo los precursores de una nueva era: la de la información y las nuevas tecnologías.

Para el autor, lo que se ha tendido a llamar "civilizado" desde los preceptos de la modernidad, está conectado con las formas tradicionales de enseñar y aprender, herederas del libro como documento sagrado, el cual debía ser leído en forma lineal. En oposición a ello, se encontraría la barbarie o formas de acceder al conocimiento de los bárbaros centrada en los nuevos lenguajes digitales, en donde es la imagen y la hiperconexión textual que se da al navegar por la red, la que predomina en las lecturas de los estudiantes de hoy (Baricco (2008).

El aporte central del pensamiento de Baricco (2008) para este trabajo tiene que ver con señalar cómo los jóvenes de esta época brindan una especial atención al mercado, así como a las dinámicas e ideas que este promulga. Adicional a ello, menciona que la forma predominante de conocer de los jóvenes se caracteriza por la rapidez y fugacidad de la información que reciben a toda velocidad desde los medios. Siendo la imagen y sus posibilidades de sentido, el eje central de gran parte de las interacciones que tiene el joven con los medios de información. De ahí que la tendencia al acercarse a la red, sea la de 
navegar en la superficie de las imágenes que se van transformando en signos cada vez más vacíos de un sentido profundo o anclado en un solo punto (Baricco, 2008)

Las ideas de Reguillo (2007) y Baricco (2008) sobre cómo comprender algunas de las dinámicas de los jóvenes enlazados con las nuevas tecnologías y los entornos virtuales, son importantes en este estudio, en tanto nos permiten analizar cómo dichos jóvenes se relacionan con los textos, incluidas las imágenes que se publican en espacios virtuales como el perfil en Facebook. Comprender cómo se da la producción de sentido del joven, es crucial porque nos facilita entender por ejemplo que las fotos que se publican y se leen en las redes sociales, se convierten en signos que adquieren su significado y contenido en relación con otros signos que pertenecen al entramado hipertextual de Internet y cuyos sentidos son errantes y no fácilmente localizables.

Dichos signos entrarían en la lógica del zapping. Este consiste en el ejercicio que hacen los usuarios de pasar de un programa de televisión a otro, mostrando la insatisfacción de los receptores, quienes siempre estarían buscando un nuevo estímulo a través del cambio rápido y constante de canal (Urresti,2008). El zapping que funciona para la televisión, se convierte en una interesante analogía con lo que ocurre con algunos usuarios de Internet, quienes al estilo zapping, van pasando de un signo a otro (Urresti,2008), de una imagen a otra, de una foto a otra, por ejemplo, en redes sociales como Facebook.

Por otro lado, y dado que interesa profundizar en lo que significa ser joven hoy en día en conexión con los medios, las nuevas tecnologías, y, muy especialmente, con lo virtual, retomemos una postura fundamental a este respecto que proporciona Muñoz (2010): 
El concepto de juventud que hoy conocemos, a mi parecer, tiene su origen en los medios de comunicación y en las nuevas tecnologías de la información donde han sido representados y de los cuales se han apropiado. En su evolución, hemos pasado de los medios masivos (radio, televisión, cine...) a los nuevos medios, a la comunicación digital interactiva mediada por la red de Internet. Las convergencias tecnológicas han producido un nuevo lenguaje y nuevas formas de comunicación que, a su vez, han construido nuevas subjetividades, en particular entre niños y jóvenes. (p. 27)

Lo tecnológico y, más exactamente lo virtual, ha permeado y posibilitado entonces que otras formas de ser joven emerjan. Esto no significa que las generaciones más recientes o inmigrantes digitales, como los denominó Piscitelli (2009), se encuentren totalmente influenciadas por las nuevas lógicas las comunicaciones en red, y que se dan sobre todo desde Internet. Ello significa que los jóvenes que han nacido en las últimas dos décadas, se han encontrado con un entorno digitalizado desde su nacimiento, teniendo acceso a tecnologías de la comunicación y a dispositivos digitales desde muy tierna edad, lo que hace que tengan, según este autor, una facilidad más amplia para manipular dichos artefactos Piscitelli (2009). Adicional a ello, Piscitelli (2009) desarrolla cómo las maneras de acceder al conocimiento se han ido modificando. Ya no se aprende de la misma manera. Hecho que a la escuela le ha costado des-aprender, pues en el espacio académico aún existe cierta reverencia al libro y a la adquisición de los saberes a partir de textos lineales (Piscitelli,2009). Dichas estrategias de aprendizaje, empiezan a chocar con la forma en que los jóvenes de ahora están acostumbrados a aprender, las cuales están más conectadas con 
la lectura de textos discontinuos que se apoyan en gran medida en la imagen y en lo multimedia.

Nos encontramos en la era de los nativos digitales (Piscitelli ,2009), es decir en una época en que las formas de comunicación e interacción, así como las estrategias para adquirir el saber, se han modificado desde el consumo de textos lineales, a otro en donde el sujeto joven deambula en un mar de información que lo lleva de un signo a otro (Piscitelli ,2009). En ese navegar, el joven se ha convertido en un prosumidor. Dicho concepto hace referencia a las publicaciones que realizan en la red jóvenes de distintas edades y niveles socioeconómicos y culturales. Frecuentemente lo hacen en las redes sociales, dando a conocer aspectos de sus vidas, para que otros los vean (Urresti, 2008). Es decir, el joven empieza a elaborar sus propios contenidos en la web, teniendo acceso además a comentarios que otros prosumidores hacen de lo que él crea (Piscitelli, 2009). Se dice que el joven en la actualidad sería un prosumidor en tanto consume contenidos, pero a la vez los produce (Urresti, 2008). Todas estas ideas que conectan al joven con los medios, específicamente con lo virtual, son de gran valor en esta investigación en tanto nos permiten situar a esos sujetos jóvenes en un contexto particular: el entorno virtual.

Los jóvenes de hoy en día pertenecen a un entorno que les posibilita una interacción con muchas opciones para acceder y crear contenidos. Serían, pues, nativos digitales. Así los describe Pisticelli (2009):

Los nativos digitales aman la velocidad cuando de lidiar con la información se trata.

Les encanta hacer varias cosas al mismo tiempo. Todos ellos son multitasking y en muchos casos multimedia. Prefieren el universo gráfico al textual. Eligen el acceso aleatorio e hipertextual a la información en vez del lineal propio de la 
secuencialidad, el libro y la era analógica. Funcionan mejor cuando operan en red, y lo que más aprecian es la gratificación constante y las recompensas permanentes (que en muchos casos pueden ser desafíos todavía más grandes que los que acaban resolver. Pero, sobre todo, prefieren el juego al trabajo serio y envarado. (p.48)

La razón por la que se cita y retoma este concepto de nativo digital cuando hablamos de jóvenes, es porque se considera que el joven, además de ser un agente de transformación social Muñoz (2010), también es un ser que se encuentra permeado por su entorno: el mundo virtual y las nuevas tecnologías de la información. De ahí que sea provechoso encontrar algunas descripciones que nos sitúen en el contexto actual. Por supuesto que el concepto de nativo digital es usado para describir no solamente a los sujetos entre los 14 y 17 años de edad, sino incluso a los de menor edad, quienes desde muy temprana edad empiezan a tener interacciones con los artefactos tecnológicos. Sin embargo, se considera que para entender hoy en día el modus vivendi de muchos de los jóvenes de nuestra época, es importante analizar sus gustos y acciones desde la relación que tienen con las tecnologías, y, más específicamente, con lo virtual.

Según las conceptualizaciones de autores como Urresti (2008), Pisticelli (2009), Morduchowicz (2012), Reguillo (2007), la estructuración que hacen los jóvenes de su identidad, gustos, y, por supuesto, la forma en que perciben al otro, se ve mediada por las nuevas tecnologías. A través de éstas comparten experiencias y se presentan ante los demás en la manera en que prefieren ser percibidos (Morduchowicz, 2012). De ahí que la imagen y las posibilidades significativas que brinda, sea una fuente por excelencia de auto presentación del joven, por ejemplo, en las redes sociales (Morduchowicz, 2012). 
Las formas mismas de comprender la relación con los otros y de interpretar las imágenes que presentan desde la red, se han ido modificando a partir de esos preceptos que brinda el contexto en el que nos encontramos. Allí las nuevas tecnologías están a la orden del día, incorporándose incluso en el ámbito de las interacciones con los otros. Adicional a ello, permean el consumo de ciertos bienes simbólicos y productos culturales que proveen las industrias culturales al interior de las lógicas del mercado (Reguillo,2007). Claro está, y como bien lo señala esta autora, esto no significa que los jóvenes asuman siempre sin más estas posibilidades del sentido que les brinda el sistema económico. Muchos de ellos realizan una relocalización de los flujos de información globalizada, dotándola de nuevos sentidos situados en marcos de significación que son reelaborados por el propio joven (Reguillo, 2009). Postura que nos devuelve a la concepción de joven como un sujeto activo Muñoz (2010), capaz de consolidarse como un agente de cambio social y, no como un mero artefacto del sistema.

La postura que propone Reguillo (2007) es de interés para este trabajo por dos razones. La primera es que tiene en cuenta el consumo que hace el joven de aquellos bienes simbólicos que tiene a la mano, para crear ante los demás la imagen que desea proyectar. Lo que significa que un espacio como la foto de perfil y la forma en que allí se proyecta el yo, responde a una serie de estímulos internos, pero a la vez externos, que provee la cultura y el contexto en que se desenvuelve el joven. Se parte de que esas representaciones contienen en sí mismas toda una carga simbólica y cultural que deviene del contexto actual de los jóvenes. En segundo lugar, las ideas de Reguillo (2007) sobre la relación jóvenesnuevas tecnologías son esenciales en este trabajo, en tanto nos permiten pensar que la 
forma en que los jóvenes perciben al mundo y a quienes les rodean, están relacionadas con el prisma de sentido que le imprimen las nuevas tecnologías y sus lógicas internas.

La categoría de joven se encuentra en este estudio en profunda conexión con las nuevas tecnologías. Por supuesto que es imprescindible reconocer que existen preocupaciones y rasgos comunes que comparten los jóvenes, sin importar la época en donde nacieron. Un claro ejemplo de ello es esa angustia que manifiestan por los cambios que se ven obligados a enfrentar tanto físicos como emocionales (Morduchowicz, 2012), los choques constantes contra los mayores y esa necesidad constante de ser reconocidos por los demás (Morduchowicz, 2012).

Sí situamos esas condiciones de lo que significa ser un joven en el contexto de los actuales medios de difusión, especialmente los que usan Internet como las redes sociales, nos encontramos frente a un nuevo tipo de joven que navega diariamente entre mares de información, y, muy especialmente, entre grandes cantidades de imágenes que lo bombardean todo el tiempo en el espacio virtual.

\subsection{Representaciones sociales}

Una de las categorías centrales en esta investigación es la de representaciones sociales, eje de las construcciones sociales que hacen los individuos en tanto miembros de una sociedad. Se retoma el concepto de Moscovici (1979), para quien las representaciones son, ante todo, el conjunto de conceptos opiniones, actitudes, valoraciones imágenes y explicaciones, producto de la vida cotidiana y que se encuentran sustentadas por la comunicación. Los miembros de un grupo social comparten esas representaciones, constituyéndose así la subjetividad social de los individuos. 
Las representaciones sociales pertenecen a grupos sociales concretos y no abarcan al conjunto de la sociedad. Son constructos dinámicos, sujetos a cambios permanentes. Se caracterizan por ser unas entidades operativas del entendimiento, la comunicación y la actuación cotidiana Moscovici (1979). De ahí que aparezcan en los contextos y situaciones en donde las personas se desenvuelven más, bien sean éstos virtuales o presenciales.

Para Moscovici (1979) una representación social es comprendida como un sistema de valores, ideas y prácticas con una doble función: primero, establecer un orden que permita a los individuos orientarse ellos mismos y manejar su mundo material y social; y segundo, lograr que tenga lugar la comunicación entre los miembros de una comunidad, proveyéndoles un código para nombrar y clasificar los diversos aspectos de su mundo y de su historia individual y grupal. Por eso podemos decir que en ambientes virtuales altamente utilizados por los jóvenes, se estarían movilizando toda una serie de representaciones que estarían configurando cómo se lee tanto a la realidad circundante, como a los demás.

Desde una conexión más clara con el lenguaje, las representaciones sociales son concebidas por Jodelete (1984), como unos sistemas de referencia a través de los cuales podemos interpretar aquello que ocurre, tanto así mismos, como a los demás. Estas nos permiten dotar de sentido a lo que nos circunda. Se convierten en la base sobre la cual comprender $\mathrm{y}$ hacerse una imagen mental sobre la realidad cotidiana. Ahora, toda representación es también una forma de conocimiento social (Jodelete, 1984) que permite dotar de significado a lo que nos rodea. Según la autora, la representación funciona como 
un signo o símbolo, pues representa a algo diferente de su referente, convirtiéndose en una imagen mental que nos permite crear significados.

Esta postura es útil en este trabajo porque permite comprender que las representaciones sociales se construyen a través del lenguaje, en conexión con el bagaje cultural de las personas que pertenecen a una sociedad. De ahí que al analizar las representaciones sociales de los jóvenes, sea preciso tener en cuenta que estas hacen parte de un proceso de construcción de sentido que se hace tanto a nivel individual como colectivo, siempre vinculado con las construcciones de sentido presentes en lo social. Así dice Jodelete (1984) al hablar de representaciones sociales

(...) se trata de un conocimiento práctico. Al dar sentido, dentro de un incesante movimiento social, a acontecimientos y actos que terminan por sernos habituales, este conocimiento forja las evidencias de nuestra realidad consensual, participa en la construcción social de nuestra realidad. (p. 473)

Lo más significativo de esta postura es que nos permite comprender cómo las representaciones sociales son construcciones que crean realidades que se normalizan en un contexto particular. Y, como usualmente conforman conocimientos socialmente compartidos, no es habitual que se cuestionen. Lo que es interesante en tanto nos permite afirmar que los jóvenes llevan en sí mismos unas imágenes mentales o representaciones sociales que rara vez entran a ser discutidas porque se asume su veracidad.

Desde posturas como las de Moscovici (1979) y Jodelete (1984), las representaciones sociales son construcciones simbólicas que se traducen en 
imágenes mentales en los sujetos, las cuales además están vinculadas con los sentidos que circulan socialmente. Cuando representamos, siempre lo hacemos en relación con algo a lo que convertimos en imagen. Y el sentido que le damos a dicha imagen mental, está traspasado todo el tiempo por el lenguaje. Es decir, la representación social es constructora de realidad, pero también es construida por esta. El proceso constructivo de realidad se daría a partir de figuras o imágenes que convierten a las ideas abstractas en significantes y significados que permiten comprender lo que nos rodea, de acuerdo a ciertos preceptos socialmente compartidos (Jodelete, 1984; Moscovici, 1979).

Las imágenes o figuraciones mentales que hacen los individuos les permiten convertir en concreto aquello que, de lo contrario, sería incomprensible. Dicho pensamiento figurativo permite la construcción de unos esquemas mentales que posibilitan a las personas compartir socialmente los significados. Este proceso es denominado objetivación por Moscovici (1979) y Jodelete (1984).

Lo interesante para este trabajo con respecto a la objetivación, es que nos permite concebir a las representaciones sociales de los jóvenes como constructoras de modos de ver, en este caso aquello que se considera estético en las fotos de perfil. Lo que se hace a partir de la interpretación que se haga de la realidad desde ciertos esquemas mentales compartidos. Al respecto, Jodelete afirma. “(...) Una persona que se dirige a otra, utiliza los signos de la lengua para (darle a ver) su representación en una esquematización compuesta por imágenes. Esta es construida en función de los objetivos perseguidos en la comunicación” (p.484). Lo que 
significa que, siempre estamos creando imágenes mentales en los demás, pero lo hacemos de acuerdo al interés que tengamos de comunicar ciertas ideas. Proceso que se da, como se verá más adelante, en la elaboración que hacen los jóvenes de sus fotos de perfil, con el fin de lograr cierto tipo de impacto en los demás.

De la misma forma, esas representaciones serían producto de la figuración y esquemas mentales que se van formando en los sujetos a partir del proceso de compartir significados a través del lenguaje. Lo que se realiza entre los sujetos de esta investigación a partir de la oralidad, de los medios masivos, lectura de imágenes, entre otros contenidos a los que tienen acceso de manera habitual.

Existe una correlación entre lenguaje-realidad-representación social, que debe ser tenida en cuenta al analizar las representaciones sociales de los jóvenes. De ahí que sea importante conocer el contexto social del que hacen parte los sujetos de la investigación. Lo que nos lleva al anclaje, concepto que Moscovici (1979) y Jodelete (1984) referencian como la conexión social y cultural que tienen las representaciones sociales con el medio. Esta permite conocer cómo se confiere el sentido a ciertas imágenes y esquemas de pensamiento, proceso que se da a partir de unos marcos de sentido que se construyen y comparten en lo social. Desde ellos, es posible realizar lecturas de todo lo que ocurre o puede ocurrir, así como generar interpretaciones que pueden dar lugar a nuevas representaciones (Moscovici,1979; Jodelete,1984). Ambos conceptos, objetivación y anclaje son de utilidad en este trabajo, pues proporcionan un marco teórico desde donde analizar cómo se construyen las representaciones sociales que nos ocupan. 
Para abordar el concepto de representación social también retomamos a Abric (2001), para quien estas son un conjunto de significaciones relacionadas con un objeto y compartidas por los miembros de la sociedad. Es decir, tienen un carácter colectivo, no sólo cognitivo para funcionar. Al ser colectivas, están influidas además por el contexto del cual parten. De ahí que, para poder estudiar las representaciones sociales, es necesario tener en cuenta la situación desde donde emergen; es decir sus condiciones de producción, que incluyen elementos ideológicos, así como aspectos jerárquicos con relaciona al lugar que los individuos ocupan en lo social Abric (2001). Es fundamental aclarar qué entiende Abric (2001) por representación y cómo esta es estructurada, dado que tendrá después repercusiones teóricas y metodológicas en el tratamiento de las representaciones de los de los jóvenes. Abric (2001) afirma que la representación:

Así definida, la representación es constituida pues de un conjunto de informaciones, de creencias, de opiniones y de actitudes al propósito de un objeto dado. Además, este conjunto de elementos es organizado y estructurado. El análisis de una representación y la comprensión de su funcionamiento necesitan así obligatoriamente una doble identificación de su contenido y la de su estructura. (p.90)

Los elementos que proporciona Abric (2001), nos sirven para analizar cómo están estructuradas las representaciones sociales de los jóvenes, es decir nos aporta la necesidad de comprenderlas como a un conjunto organizado, cuyos elementos se encuentran correlacionados. 
Para para Abric (2001) la representación produce anticipaciones y expectativas que preceden por ejemplo a la acción y que, de alguna manera, modelan cómo se interpretan algunos elementos y experiencias en lo real. De lo que se trata es que esa realidad se crea en buena medida a través de las representaciones que la preceden.

La interacción misma hace que en la mayoría de los casos «los juegos están hechos de antemano» las conclusiones son planteadas antes incluso de que inicie la acción. Finalmente, en tanto que representación social, es decir reflejando la naturaleza de las reglas y de los lazos sociales, la representación es prescriptiva de comportamientos o prácticas obligadas. Define lo lícito, tolerable o inaceptable en un contexto social dado. (Abric, 2001, p.16)

Si las representaciones preceden a la acción y a la manera en que interpretamos lo que vemos, por ejemplo, a partir de una imagen, analizar dichas representaciones se convierte en un campo fértil cuando se trata de comprender qué sistemas de sentido intervienen en este proceso, lo que corresponde con la piedra angular de esta investigación.

Con relación a la estructura de las representaciones sociales, el autor propone que estas se conforman a partir de un núcleo y unos elementos periféricos que se conectan con este. El núcleo puede estar compuesto por más de un elemento, dotando a la representación de su significación; pero además agrega que esta última depende también de la naturaleza del objeto representado, de la relación que el sujeto o grupo mantiene con el objeto y del sistema de valores y contenidos ideológicos presentes en el entorno Abric (2001). El núcleo es entonces el elemento unificador y más estable de las representaciones por ser más resistente al cambio. Con ello no se dice que no pueda ser modificado. De hecho, el 
autor señala cómo cuando efectivamente se dan cambios en el centro de la representación, los elementos periféricos también se modificarían.

Por su parte, los elementos periféricos de las representaciones sociales son aquellos que, a pesar de no estar en el centro de la misma, sí ayudan a comprender cómo está constituida en tanto poseen las partes más accesibles de la representación, es decir lo más concreto e inteligible para quien la analiza (Abric,2001). Proceso que implica además entender su jerarquía y organización interna. Aspectos fundamentales en tanto permiten al investigador percibir informaciones que no siempre son tan evidentes, tales como valoraciones y juicios relacionados con el contexto en que se encuentra el objeto de la representación (Abric,2001). Elementos que nos servirán para comprender qué componentes existen dentro de cada una de las representaciones de los jóvenes.

Por otro lado, Abric (2001) afirma que al trabajar con representaciones sociales, es preciso conectarlas con aspectos emocionales, culturales, económicos, tanto de los sujetos en particular, como de algunos de los grupos a los que éstos pueden pertenecer, porque los objetos que las hacen posibles o de los que se desprenden, cobran significación al adherirse a las redes de sentido que circulan en los discursos manejados y compartidos en lo social (Abric,2001) y puestos en circulación a través de los medios masivos, entre ellos Internet.

Adicional a ello, Abric (2001) menciona que cuando se trata de comprender cómo está constituida una representación, específicamente su núcleo, es preciso identificar también el tipo de prácticas sociales que la han hecho posible, lo que es interesante porque nos permite poner sobre la mesa cómo ciertos esquemas de sentido aceptados socialmente 
desde un espacio virtual como Facebook, pueden intervenir en la configuración de cierto tipo de representaciones en los jóvenes. Por otro lado, las ideas de Abric (2001) son útiles porque ayudan a entender cómo en la conformación de una representación social, entran en juego tanto los consensos entre varias personas, como algunas diferencias que serían más bien particulares y propias de los individuos (Abric,2001). Lo que nos permite analizar las representaciones desde dos perspectivas; la primera tiene que ver con la relación que tienen con las ideas y acervos culturales que vienen de lo social; la segunda se refiere a cómo la individualidad de los sujetos, sus pulsiones más específicas, también se conectan con sus representaciones.

En resumen, se puede decir que la teoría de Abric (2001) sobre las representaciones sociales, es de gran ayuda porque nos interesa analizar no solo los elementos individuales que intervienen en la creación de las mismas, sino cómo el contexto socio cultural también tiene un papel importante en este proceso.

\subsection{Aproximación al concepto de estética}

La estética ha tenido varias interpretaciones a lo largo de la historia, siendo vinculada en varias de ellas con la filosofía de lo bello, particularmente con el arte. De hecho, una definición de estética que se ha manejado por siglos es aquella que la relaciona con la comprensión filosófica del arte (Gutiérrez, 2005). Así, por ejemplo, para Ortega y Gasset (1992) la experiencia estética se conectaba con la conciencia de la imagen que tenía quien estaba frente a un objeto artístico. Esas imágenes, al ser artísticas, se encargaban de mostrar a quien las observaba, una realidad distinta de ellas mismas (Ortega y Gasset, 
1992). Es decir, tenían el poder de representarse a sí mismas, de llevar a quien las percibía hacia lo que estaba ausente y, de alguna manera, presente en la experiencia misma de contemplarlas. Siendo precisamente esta la experiencia estética misma (Ortega y Gasset, 1992). De hecho, la obra aludiría a otra cosa completamente distinta de los elementos reales que la componen, convirtiéndose en una presencia, pero sólo de sí misma, es decir, crearía otra realidad misma, convirtiéndose en objeto estético puro, que no se refiere a nada que esté por fuera de ella misma (Ortega y Gasset, 1992).

En Ortega y Gasset (1992) encontramos una idea sobre lo estético y sobre la imagen, que, aunque está pensada para el arte, nos proporciona un marco de interpretación de la imagen, que la desliga de su carácter representativo como signo. Adicional a ello, aporta cómo las creaciones humanas son ante todo productos culturales intencionados y contextualizados. Tal idea nos sirve para identificar a la experiencia estética, entendida esta como la relación de un sujeto con un objeto desde una perspectiva histórica y socio cultural situada (Ortega y Gasset, 1992).

Por otro lado, y desde una perspectiva menos humanista y más conectada con el ser, Heidegger (1958) define a la estética como al estado sentimental del ser humano en relación con lo bello. En esta perspectiva, el arte se convierte en la expresión de lo bello. Lo estético (Heidegger, 1958) empieza y termina en el sujeto. Es decir, existe una experiencia estética cuando tenemos un estado sentimental sobre un objeto bello, pero esta empieza y termina en el sujeto mismo, no en la obra.

Otras ideas relevantes sobre cómo han evolucionado las ideas sobre la estética y su relación con lo bello, aparecieron en las conceptualizaciones de Adorno (1970). Para este 
autor, la estética se conecta con la relación entre el sujeto y las obras de arte, las cuales son enigmáticas por naturaleza (Adorno ,1970). Es decir, la experiencia estética se conecta con apreciar la obra de arte como cosa sensible que no representa algo diferente a sí misma (Adorno,1970). Apreciar estéticamente un objeto artístico es, en sí mismo, un acto de negación y protesta contra lo que impone el mundo establecido. Lo estético sería entonces una toma de posición del pensamiento frente a la objetividad (Adorno, 2004). El momento estético del que habla es aquel en donde el sujeto en vez de encontrarse a sí mismo, encuentra al objeto; se abre a él (Adorno, 2004). Allí la experiencia estética es de naturaleza dialéctica, o sea existe una tensión entre el sujeto y el objeto artístico (Adorno, 2004). Dicho objeto, no simboliza las ideas, sino que penetra en lo no conceptual (Adorno, 2004). Una experiencia estética es para Adorno ante todo una mímesis, entendida ésta como la apertura del sujeto a lo extraño, a lo enigmático del objeto artístico. Este último es arte en tanto representa al sufrimiento de la humanidad, dando voz a aquellos que no la tienen (Adorno, 1975).

Tales ideas sobre lo que es la estética nos ayudan a identificar qué se ha entendido por esta desde la filosofía, por lo menos desde algunos autores contemporáneos, lo que nos permite trazar el recorrido hacia la concepción de estética que se maneja en nuestros tiempos.

Realizamos el recorrido general sobre qué se ha entendido por estética apara algunos autores contemporáneos como: Ortega (1992), Heidegger (1958) y Adorno (2004), no para asimilar a las imágenes de perfil con el arte, sino para tratar de entender cómo han ido 
evolucionando las ideas sobre la estética hasta nuestros días y, por supuesto cómo podemos entenderla hoy.

De ahí que otra de las ideas que propone Adorno sobre lo que es y lo que no es arte en esta época sea de gran importancia para poder situar bajo qué concepto de estética trabajaremos. Para Adorno (2004), el arte se reconoce porque denuncia y propone una forma de ver distinta y enigmática el mundo. Luego, el sujeto aprecia ese objeto artístico en un proceso dialéctico de extrañeza; por su parte y en oposición al arte, estarían los objetos estetizados que no son arte y que han surgido y se han reproducido masivamente a través de las industrias cultuales (Adorno,2004). Aspecto interesante porque nos proporciona un marco de comprensión más amplio acerca de la relación entre estética e indicadores corporales en las fotos de perfil en Facebook, como objetos más bien tendientes a la estetización.

En la industria cultural, la belleza es considerada como un medio y no un fin. Entonces, aquellos objetos con apariencia estética que aparecen en la industria cultural tienen un fin claro: vender (Adorno,2004). Para Adorno (2004), esos objetos-imágenes que se producen y reproducen en las industrias culturales, no carecen de apariencia de belleza (Adorno, 2004), pero están alejados completamente de lo que él considera una verdadera experiencia estética, convirtiéndose más bien en los instrumentos que utiliza el poder para dominar (Adorno,2004). Un ejemplo de ello lo podríamos encontrar en las fotografías, en algunos objetos, accesorios y ropa usados en las fotos de perfil por parte de muchas personas, entre ellas, los jóvenes. 
El concepto de estetización es importante en este trabajo en tanto se analizará cómo en nuestros tiempos, la imagen en sí ha sido estetizada. Es decir, se le han agregado ciertos sentidos que llevan a identificar lo estético con algunos elementos específicos, que, por lo general, fortalecen los intereses del mercado Canal Encuentro (2012). Ejemplo de ello son las formas en que se presentan los jóvenes en sus fotos, los accesorios que usan, las poses que asumen. Todo parece responder a una estetización de la existencia en donde lo más importante parece ser no el tener una experiencia estética artística, como lo señalaban los autores mencionados Ortega (1975), Heidegger (1958), Adorno (2004), sino mostrar a los demás el producto de un embellecimiento personal muy conectado con aquellas ideas de belleza que se promulgan por doquier en las industrias culturales de las que nos hablaba Adorno (2004). Estas se valen, para lograrlo, de estrategias publicitarias, programas de televisión, canales en Internet, redes sociales, entre otros tantos espacios en donde se hacen evidentes cuáles son hoy las tendencias que han proliferado en los principales consumos culturales.

Lo estético ya no sería como lo señalaba Adorno (2004), una mímesis (o relación dialéctica entre el objeto artístico y el sujeto), que buscaba transformar la realidad. En estas sociedades en donde el consumo cultural está exacerbado y al servicio del capitalismo, se daría es una estetización de los objetos (Adorno,2004). La imagen, específicamente la que se postea en un espacio como el perfil de Facebook, funcionaría como un objeto-signo no artístico, pero sí estetizado. Cargado, además, de una cantidad de signos que lo embellecen. Ahora bien, tal proceso de embellecimiento de la imagen-signo es intencional, como lo señalábamos más adelante al visibilizar a través de algunas investigaciones contemporáneas como las de: Morduchowicz (2012) Chaparro, Echeverry, 
Arévalo (2014); Almansa, Fonseca, Castillo (2013); Dillon (2013); Basile y Linne (2014); Bonacci, (2013) cómo el joven crea una versión de sí mismo altamente estetizada, especialmente a través de mecanismos como las fotos que publica en las redes sociales.

Esos signos-fotos de perfil gozarían actualmente de lo que Adorno (2004) denominó: apariencia estética, que, por supuesto, no carece de apariencia de belleza. Lo que ocurre, como lo señala el autor, es que esos signos se deben decodificar en términos de mercancía, pues no presentan una belleza que tenga un fin en sí misma, sino que entran en la lógica utilitaria que promulga el capitalismo (Adorno,2004). Verse bello, retocar una foto de perfil, se parecería más, en este orden de ideas, a producir una mercancía, que luego será expuesta en el mercado. Siendo puesta después a disposición del público, a través de los mecanismos que brindan las redes sociales para exhibirlas a todos.

Existe entonces en la actualidad una tendencia a gozar con la apariencia estética de todo. La vida misma se vuelve un objeto estetizado que hay que mostrar a los demás, pero no necesariamente como se vive en verdad en lo cotidiano, sino como debería ser. Los jóvenes no presentan por lo general en sus fotos de perfil aquellos momentos en que se encuentran enfermos o en una situación desfavorable Dillon (2013). Es decir, no ponen a disposición las otras imágenes corporales de sí mismos en donde, desde el punto de vista de la estetización socialmente compartida, exista ausencia de belleza. Lo que implicaría que esas imágenes, alejadas del cánon de belleza socialmente reconocido, no serían dignas de ser consumidas Bauman (2007).

Pareciera que cualquier acto puede ser actualmente considerado estético, siempre y cuando cumpla con las exigencias de belleza que nos vende el mercado Dillon (2013). Una 
foto de perfil que se toma por ejemplo en el baño y frente a un espejo resulta ser hoy en día un signo-foto con apariencia de belleza, siempre y cuando las poses, actitud con que se aparezca, la ropa y accesorios que se usan, demuestren que se está en correspondencia con los más valorados consumos culturales de la época.

Actualmente el yo se convierte en una mercancía (Adorno, 2004) que el mercado elevaría a una condición de objeto estético. Lo anterior, nos lleva a cuestionarnos ¿qué ocurrió con la postura de la experiencia estética que la asimilaba como un fin en sí misma al contemplar algo considerado bello, específicamente cuando se hablaba de los objetos artísticos? Por supuesto que las fronteras entre aquello que hoy es considerado arte y lo que no, en la actualidad son más bien difusas. El punto problematizador al que apuntamos es que, actualmente, todo se encuentra estetizado, pero con un fin claro: ser útiles a las lógicas del mercado.

\subsection{Apreciaciones sobre el concepto de corporeidad}

Si Se trata de acercarse a la comprensión sobre lo que es la corporeidad, es preciso revisar algunas ideas que sobre este concepto han desarrollado algunos autores. Uno de ello es Merleau Ponty (1993,) quien reflexiona sobre la existencia de un esquema corporal. Este esquema no sería la imagen del cuerpo sino la unidad que es percibida por el sujeto, que le permite encontrar un significado a cada parte de dicho cuerpo y su relación con el resto de partes (Merleau Ponty,1993). Además, la conciencia del sujeto se extiende no solo a sus partes corporales, sino a la relación que tiene con los objetos (Merleau Ponty,1993). 
Lo anterior, nos permite observar cómo hablar de este concepto no se agota en una reflexión sobre lo que se puede entender por cuerpo. Más bien nos hace apreciar lo corporal en dos dimensiones. La primera, tiene que ver con la consciencia del sujeto sobre su propio cuerpo; la segunda con el hecho de que esa consciencia incluye el saberse un ser corporal en relación con los demás (Merleau Ponty,1993).

Las ideas de Merleau Ponty (1993) muestran un cuerpo cuya corporeidad se constituye en y por la relación del sujeto con el mundo y los objetos que le rodean. De hecho, para este autor un esquema corporal es posible en la medida en que existe una conciencia e intencionalidad, no solamente sobre las partes del cuerpo, sino sobre los objetos que lo circundan.

Adicional a lo anterior, Merleau Ponty (1993) menciona que a partir del cuerpo se crean una serie de hábitos que nos indican cómo relacionarlos con el mundo y sus objetos. Existe, podría decirse, prácticamente una memoria corporal que nos indica en nuestra carne, cómo nos conectamos con lo que nos rodea (Merleau Ponty,1993). Lo corporal se entendería desde esta postura, como una vivencia que es experimentada en la misma carne del sujeto. Carne que es susceptible a las intencionalidades, percepciones y formas de relacionarse el sujeto con los objetos del mundo y con los demás (Merleau Ponty,1993). Aspecto que puede encontrarse por ejemplo en el tipo de relaciones que establecen los jóvenes con los objetos que considera estéticos y que utiliza frecuentemente en la elaboración de sus fotos de perfil.

Por su parte, Rico (1998) maneja un concepto de corporeidad en el cual el cuerpo humano tiene una determinante influencia sobre aquello que constituye la realidad que lo 
circunda (Rico ,1998). Es decir, que aquello que se encuentra en el campo de acción de lo corporal, tiene que ver con las extensiones que hemos creado para nuestros cuerpos y que se convierten en bienes culturales (Rico ,1998).

Otra idea que desarrolla Rico (1998) y que corresponde con las posturas de Merleau Ponty, (1993), es que nuestra corporeidad se construye no solamente desde nosotros mismos, sino que el cuerpo es a la vez un objeto para el prójimo, quien además participa en la construcción de nuestro ser corpóreo. Allí la mirada del otro revela mi ser, en este caso, mi ser corpóreo en el mundo Rico (1998). Tener en cuenta la mirada del otro como constitutiva de mi ser corporal, permite analizar cómo las posturas corporales y objetos que allí muestran los jóvenes, hacen parte de unos esquemas corporales que se construyen desde sí mismos, pero también a partir de la interacción con los demás (Rico ,1998). El acto mismo de tomar una fotografía y mostrar en ella ciertos gestos y objetos, presupone que es un acto de sentido dirigido a los demás; es decir a los espectadores de esas imágenes.

Un aspecto central en el pensamiento de Rico (1998) en relación con lo corporal, es que para él tanto el cuerpo humano como lo corporal, se puede interpretar de acuerdo a unos usos históricos y culturales situados. Lo que implica que, aquello que interpretamos y percibimos del mundo y que manifestamos a través de nuestros cuerpos, está mediado no solo por la mirada de los otros, sino por el momento histórico y cultural particular de los sujetos (Rico ,1998).

Ahora, con relación a los objetos y la corporeidad, Rico (1998) afirma que la conciencia de nuestro propio cuerpo y de aquello que lo rodea es selectiva. Lo que 
significa que las elecciones y cualidades que les otorgamos a los objetos, son ante todo interpretaciones que se materializan en lo corporal (Rico ,1998). De ahí que los sentidos que le damos por ejemplo a ciertas partes corporales estén delimitados de antemano por la cultura y las significaciones sociales que se hayan construido sobre estas. Lo que incluye también a los objetos que funcionan como extensiones de nuestro cuerpo. Todo lo anterior se construye en lo social "La consciencia estimativa del cuerpo, repetimos, es primero social porque nos la inducen los demás mediante opiniones, creencias y normas introyectadas con el ejemplo, la actitud ante nosotros y la palabra" (Rico, 1998, p. 71)

De ahí que la forma en que los sujetos se perciben a sí mismos, desde su ser corpóreo en relación al mundo y sus objetos, está fuertemente conectada con unas construcciones simbólicas que se crean y mantienen en el contexto social y cultural al que éstos pertenecen (Rico ,1998). De hecho, las ideas mismas que tenemos acerca de nuestra naturaleza corporal estarían fuertemente determinadas por el contexto social y cultural. Lo que implica que pueden variar de época a época y en conexión con los procesos históricos y económicos que se estén dando en un momento específico Heidt (en Fernández, Zelich y Monter ,2004). De allí se desprende que las ideas que se tiene sobre la belleza y aquello que es agradable a la vista, depende también de esos procesos situados en un contexto específico. Lo que permite que ciertas posturas corporales y el uso de algunos objetos sean considerados atractivos tanto para sí mismos como para los demás.

Con respecto a las posturas corporales Heidt (en Fernández, Zelich y Monter ,2004) escribe:

Si observamos a las personas cuando pasan por delante de los omnipresentes espejos, por ejemplo, en unos grandes almacenes, nos damos cuenta de que 
prácticamente todas arrojan una fugaz mirada sobre su imagen y adoptan un consiguiente cambio de postura o un breve movimiento para corregir el peinado o la ropa $(. .$.$) hoy las imágenes idealizadas del cuerpo están permanentemente visibles a$ través de la publicidad, el cine y la televisión. Estas imágenes incitan a realizar comparaciones: vemos lo que somos y vemos lo que podríamos ser, con un pequeño esfuerzo (p.50)

En este texto consideramos que, efectivamente, tanto las posturas corporales como el tipo de accesorios y ropa que usan los jóvenes en sus fotos de perfil en Facebook, pueden brindar grandes pistas acerca de las representaciones que tienen sobre la estética. Para analizar este asunto, se parte de que lo corporal está fuertemente marcado no solamente por las vivencias del sujeto, sino con su relación con los demás y con el contexto social, cultural y económico imperante Heidt (en Fernández, Zelich y Monter ,2004), de acuerdo a lo desarrollado teóricamente por los autores referenciados.

\subsection{Acerca de la imagen}

La imagen, y, más exactamente, la forma en que la comprendemos, se ha ido transformando a lo largo de la historia de la humanidad. Se pretende mostrar, aunque brevemente, cómo se le ha comprendido, con el fin de situar teóricamente en qué momento de la discusión sobre la imagen nos ubicamos.

Uno de los autores que ha trabajado el concepto de imagen desde la antigüedad hasta nuestros días es Debray (1994). Desde su aporte teórico, ha categorizado los diferentes estadios de la imagen. El primero de ellos es la logósfera. Término que el autor enlaza 
directamente con lo sagrado, con ese estadio en el que el ser humano creía fervientemente que, a través de la imagen, era posible capturar la esencia de lo sacro. La imagen estaba a su vez conectada con la muerte y con la posibilidad de traer a este mundo la presencia de un dios o de un difunto (Debray,1994). Lo que significa que esta tenía un halito mágico y era ante todo un ser, una presencia. Tenía el carácter de ídolo que se sitúa en el campo de una existencia espiritual.

El segundo estadio que desarrolla el autor es denominado: grafósfera. Allí la imagen se convierte en arte, en representación; es decir la imagen ya no es en sí misma un objeto de adoración porque se encarne de alguna manera en el objeto, sino que está en vez de otra cosa, pero remite a su original o a aquello que evoca. Tiene sentido en tanto lleva a percibir ciertos estados de contemplación que la elevan por encima de lo sensible (Debray, 1994).

Por último, aparece el estadio de la imagen denominado por Debray (1994) videósfera, en donde la imagen ha perdido su capacidad para representar. Se ha convertido más en un signo auto referencial; es decir queda vaciada de un sentido que remita a otra cosa. Su finalidad es principalmente la de entretener y vender. Es decir, en este estadio, la imagen no es concebida ni como un objeto sagrado que se convierte en el foco de adoración porque contenga en sí misma a la entidad, ni es la representación de otra cosa que está situada en el mundo de lo sensible o de lo concreto (Debray, 1994). Es más bien es un signo que lleva en sí mismo la opción de cambiar de sentido, es decir de fluctuar en los océanos de la significación que son volátiles por naturaleza (Debray, 1994). 
La imagen se convierte en la videósfera en imagen de sí misma. Es ahora un signo vacío de contenido que se llena de sentido en su fluctuación nunca inmóvil, negociando ese sentido con el usuario y con la red de significados que se tejen en los medios a través de la interacción con otros (Debray, 1994). El autor planeta que, en este estadio de la imagen, el ser humano tiende a un regreso a lo mítico porque aquello que se muestra a través de la imagen ya no representa. Es decir, el signo pierde su capacidad de representación en tanto está vacío. Existe solo un mar de referentes que construye realidades (Debray, 1994). Lo anterior es evidenciable por ejemplo en las fotos que circulan en la red o las imágenes publicitarias, que ya no parecen referirse a otra cosa que estuviera más allá de ellas mismas, sino que cuando se vende un producto, se vende es más la imagen de lo que implica ser por ejemplo más guapo o exitoso; no el producto en sí mismo. Se comercia es con la posibilidad de ser feliz, acorde con algunos modelos que tenemos instaurados sobre lo que podría implicar serlo Bauman (2007).

En este trabajo retomaremos este último estadio que planteó Debray (1994), en tanto se considera que es en este periodo de la imagen en donde podemos situar a los fenómenos que ocurren todo el tiempo en la red, y, más específicamente, en las fotos de perfil que aparecen en redes sociales como Facebook. Se parte de considerar que la imagen ha perdido en estos contextos virtuales su capacidad representativa, para convertirse en un signo que conduce irrefrenadamente a otros signos (Debray, 1994), cuyos sentidos errantes deambulan y se resignifican.

Otro autor que se encargó de analizar la imagen fue Manovich (2005). Su trabajo se centra específicamente en conceptualizar cómo podemos entender a la imagen en el mundo 
digital, desde los diferentes formatos en los que aparece. La analiza por ejemplo en el cine, Internet, entre otros medios audiovisuales.

Este autor conecta con Debray (1994), específicamente en el estadio de la videósfera. Algunos de los puntos en que los dos autores convergen, tienen que ver con señalar que la imagen en lo contemporáneo se caracteriza por su fluidez (Manovich, 2005). Lo que expresa que los significados profundos y densos de las antiguas imágenes, pasan a ser reemplazados por otros que más bien fluyen en una suerte de continuidad de sentido (Manovich, 2005). Estos no se estancan en un punto, sino que remiten siempre a otros sentidos, que, a su vez, se direccionan a otros, sin anclarse en ninguno definitivamente (Debray,1994; Manovich, 2005).

Lo anterior desemboca para Manovich (2005) en la creación contemporánea de una estética caracterizada precisamente por esa fluidez y continuidad, en donde los límites entre los significados y sentidos de las imágenes, se van borrando, dado que aquellos elementos que muestran se van fundiendo entre sí. Tal mescolanza se da, por ejemplo, entre imágenes que evocan lo antiguo con otras que representan más a las formas de representación contemporáneas (Manovich,2005). La imagen en la actualidad tiende a la mutación, a ser parte de unas composiciones digitales que parten de unas estéticas específicas (Manovich ,2005). Este aporte nos ayuda a explicar cómo comprender muchas de las fotos de perfil de los jóvenes, en donde se realizan montajes con juegos de colores, objetos graficados a partir del uso de programas especiales para tal fin, maquillajes virtuales, entre otros elementos que entran en el campo de análisis de esta investigación, en tanto representan accesorios y objetos que se conjugan con la corporalidad de los jóvenes. 
La imagen, en sus formas actuales de manifestarse, deja entrever unas concepciones estéticas muy conectadas con la fluidez y fugacidad que nos plantea el mercado y sus lógicas consumistas (Bauman, 2007).

Frente a estas ideas que conectan a las nuevas estéticas con la imagen, tal como aparece en la actualidad en algunos medios masivos como la web, Darley (2002) plantea que ha ido emergiendo en la contemporaneidad un nuevo terreno estético de la cultura visual, en donde las imágenes llevan en sí mismas unos sentidos que navegan desde la superficie. Lo que quiere decir, que los sentidos que suscitan no van mucho más allá de un instante efímero en donde se crea en el espectador una serie de emociones, tan deslumbrantes como pasajeras (Darley, 2002). Para el autor en cuestión, la imagen en la actualidad se encuentra en la era de los significantes. Un signo-imagen, lleva a otra, y esta, a su vez a la siguiente. Lo anterior entra en consonancia con las posturas teóricas que hemos ido desarrollando en este apartado, en donde la imagen se juega sus sentidos en la actualidad desde lo pasajero, efímero, fluctuante y continuo (Debray,1994; Manovich, 2005; Darley,2002).

Otro aspecto relevante que analiza Darley (2002) en relación con la imagen contemporánea, es el de serialización-repetición. Llama la atención la referencia que hace a Benjamin (2015), como uno de los primeros teóricos que se ocupó de este fenómeno cuando teorizó acerca de la fotografía. Darley (2002) parte del trabajo de Benjamin (2015) para señalar cómo las imágenes de nuestra cultura digital, contienen en sí mismas el fenómeno de la repetición, heredada de los procesos de reproductibilidad técnica que surgieron a raíz del advenimiento de los nuevos modos de producción en serie de la 
fábrica. La imagen conservaría ese carácter serial y reproducido, en la medida en que tanto los objetos como las personas que aparecen en imágenes como fotografías, han tenido un proceso de cosificación, convirtiéndose ellas mismas en objetos de consumo de las masas (Darley 2002; Bauman, 2007).

La idea del ser humano cosificado o convertido en objeto frente a las imágenes que produce de sí mismo (Darley, 2002; Bauman, 2007) nos permite tener un punto de partida a la hora de analizar cómo ese proceso puede estar muy conectado con el tipo de representaciones que tienen los jóvenes sobre la estética en un mundo contemporáneo, en donde las prácticas y lógicas consumistas han permeado casi la totalidad de las acciones, deseos y necesidades humanas (Bauman, 2005).

\subsection{Sobre la fotografía}

Para hablar de la imagen fotográfica, se hace necesario realizar un breve recorrido por algunas de las posturas existentes sobre esta categoría. Para hacerlo, se retoman los trabajos teóricos de algunos pensadores cuyas posiciones resultan esclarecedoras y pertinentes a esta investigación. Iniciaremos con Barthes (1989), quien realiza un importante aporte en este campo. Lo situamos en primer lugar, porque presenta una visión de la fotografía que, aún separada del mundo virtual de internet, nos permite comprender varios de los elementos que la constituyen, así como las formas en que nos relacionamos con ella. Ideas que, pese a datar de los años 80, nos proporcionan un contraste acerca de cómo se entendía la fotografía antes de los medios virtuales, con la forma en que esta es 
asimilada actualmente. Aunque, como se verá en este apartado, algunas de las ideas de este autor siguen vigentes y se pueden aplicar a análisis de la imagen- foto en nuestro tiempo.

Para Barthes (1989), todo aquello que es fotografiado es un referente. Este es, de alguna manera, vuelto a crear en el acto mismo de hacer parte de la foto. Cuando se trata de una persona, el autor escribe que la foto vuelve a crear a ese ser en un tipo de existencia que, sin embargo, está lejos de ser exactamente la misma persona que ha sido fotografía (Barthes,1989). De ahí que el yo nunca coincida con la imagen que aparece a partir de él (Barthes,1989). Lo que ocurre con la foto es que la imagen del yo sí es bastante parecida a este, pero es en definitivamente otro. El sujeto de la foto se convierte en un espectro convertido en objeto por quienes la observan (Barthes, 1989)

Desde esta postura la foto conserva su capacidad representativa; es decir, se constituye en un signo que tiene un sentido profundo y que se diferencia claramente de su referente. Idea que más adelante irá cambiando con el uso de las nuevas tecnologías, en donde veremos cómo el signo va perdiendo su capacidad representativa, en tanto las fronteras entre referente y signo empiezan a desdibujarse.

Barthes (1989) nos aporta una concepción de la fotografía en donde ese signo-foto sí posee una profundidad, un aura si se quiere, como lo expresaría Benjamín (2015). Sentido que trata de develar todo el tiempo quien lee la fotografía y que es esquivo, pese a los intentos desesperados de quien trata de apropiarse de su esencia, en el acto mismo de observarla (Benjamín,2015). Leer la fotografía de una persona implicaba para Barthes (1990) hacer un esfuerzo por comprender el contexto, la situación, los sentimientos que impulsaron tal o cual gesto, tal o cual postura. De hecho, los objetos mismos que aparecían 
en las fotografías eran interpretados en su sentido más profundo, en conexión con el significado que pudieran tener (Barthes,1990). Hoy en día, sobre todo con el advenimiento de las nuevas tecnologías, esos signos-foto se encuentran inmersos en las lógicas de la reproducción en serie de imágenes (Benjamin,2015), convirtiéndose las personas fotografiadas, en objetos-fotos cuyas imágenes fotográficas se venden en el mercado actual de la imagen, por ejemplo, en las redes sociales (Bauman ,2007).

El objeto-foto en que se convierte el sujeto a través de sus fotografías, es construido para Barthes (1999) por los demás. Aspecto que consideramos vigente en las fotografías contemporáneas. Para el autor, es a partir de los otros que la persona se convierte en un objeto, capaz de despertar tales o cuales emociones en el receptor (Barthes, 1999). Esta idea es fundamental en esta investigación, en tanto se afirma que, es a partir de los demás, de sus lecturas de las fotografías que aparecen en las fotos de perfil de Facebook, como el sujeto de la foto, empieza convertirse en un signo susceptible de ser interpretado; y, en el mismo sentido, solo en el acto mismo de leer las fotos de perfil de los demás, estos empiezan a ser construidos como objetos-signos susceptibles de ser leídos.

Otro autor que analiza a la fotografía es Benjamin (2015). Lo hace desde el advenimiento de la sociedad de masas y su afán por reproducir y acercar a las cosas. Actitud totalmente contraria con el aura, más conectada con la apreciación de los objetos artísticos, que serían únicos e irrepetibles y, por tanto, lejos de ser objetos que puedan ser simplemente acercados a través de la técnica que busca reproducirlos en masa (Benjamin, 2015). Así dice Benjamin (2015): 
Día a día se hace vigente, de manera cada vez más irresistible, la necesidad de apoderarse del objeto en su más próxima cercanía, pero en imagen, y más aún, en copia, en reproducción. Y es indudable la diferencia que hay entre la reproducción, tal como está disponible en revistas ilustradas y en noticieros, y la imagen. Unicidad y durabilidad se encuentran en está tan estrechamente conectadas entre sí como fugacidad y repetibilidad en aquella (p.32)

Se pone de manifiesto la dualidad existente para Benjamin (2015) entre la imagen que no es reproducida y la que sí lo es. La segunda representa a lo efímero y repetible, mientras la primera se conecta más con lo artístico y con aquello que se resiste a ser acercado a través de la técnica (Benjamin,2015). Estas ideas son importantes en este trabajo, porque nos permiten pensar a la fotografía de perfil como a una imagen-signo que se vincula con la fugacidad (Debray; 1994, Manovich, 2005; Darley, 2002), dada la posibilidad que tiene de ser reproducida, especialmente desde internet. Desde Benjamin, (2015) la fotografía, tal como la conocemos hoy en día, sería producto de la técnica. Estaría alejada del aura que la haría única. Aunque, por supuesto, siempre habrá cabida para la creatividad, como lo señala el mismo Benjamin (2015). Lo que interesa de estas ideas es cómo nuevamente la fotografía, específicamente la que aparece en las redes sociales, aparece en la actualidad como un signo que se dirige hacia los sentidos que se encuentran en la superficie de otros signos. Su carácter repetible y masificador, la hace volátil y fluctuante tan como lo señalaran (Debray, 1994, Manovich, 2005, Darley, 2002) al hablar de la imagen en la contemporaneidad, especialmente las que aparecen en los medios masivos, por ejemplo, las imágenes publicitarias y las que se les asemejan. 
Por último y desde una perspectiva más contemporánea, autores como Leo (en Fernández, Zelich y Monter ,2004) y Doswald (en Fernández, Zelich y Monter,2004) nos presentan una perspectiva de la fotografía que, si bien no se aleja por completo del aura de Benjamin (2015), sí ponen de manifiesto cómo la imagen fotográfica puesta a disposición de los medios masivos, ha ido adquiriendo unos matices estéticos que se sirven de prismas para construir algunas versiones de lo real. Lo que se materializa por ejemplo en la forma en que creamos a los otros a nuestra imagen y semejanza, cuando estamos leyendo un retrato Leo (en Fernández, Zelich y Monter ,2004) y Doswald (en Fernández, Zelich y Monter,2004). Leemos sus emociones, le creamos un contexto y una manera de ser, a partir de nuestras propias expectativas y concepciones estéticas Leo (en Fernández, Zelich y Monter ,2004). Se da una idealización del otro para que se parezca cada vez más al que hemos creado. De la misma forma, cuando nosotros somos los fotografiados, intentamos cuidar que los rasgos que aparecerán en nuestras fotos correspondan con un tipo de comportamientos e ideales estéticos con los que estamos interesados que nos identifiquen Leo (en Fernández, Zelich y Monter ,2004). Aparece una estetización de las fotos que, de alguna manera descuartiza la realidad, para mostrar solo los trozos que consideramos bellos o acordes con algunos ideales de belleza con los que nos asociemos Leo (en Fernández, Zelich y Monter ,2004).

Estas ideas nos señalan cómo en las fotos, específicamente en aquellas que se sabe verán muchas personas, como las de perfil en Facebook, existe toda una estetización que remite a unas representaciones sobre aquello que se considera bello o deseable para los demás. Para hacerlo, muchas personas acuden a las poses en donde todo el tiempo se está jugando con la propia imagen. Doswald (en Fernández, Zelich y Monter ,2004) denomina 
a esas posturas corporales auto escenificaciones, que se basarían en ciertos modelos de belleza socialmente aceptados Doswald (en Fernández, Zelich y Monter ,2004).

A partir de esos modelamientos, se crean imágenes que tienen la capacidad de crear la realidad misma Doswald (en Fernández, Zelich y Monter ,2004). Idea que nos da un punto de partida para empezar a reflexionar acerca de cómo las fotografías de perfil de los jóvenes en Facebook, podrían incluir sus representaciones sobre la estética. 


\section{Capítulo IV. Aproximación metodológica}

\subsection{Enfoque y paradigma en que se enmarca la investigación}

La presente investigación es formativa, dado que hace parte de un ejercicio de indagación que pretende acercarse al abordaje de una pregunta de investigación, desarrollada en el marco de una tesis de Maestría. El enfoque metodológico utilizado es mixto (cualitativo y cuantitativo), aunque se recurre a lo cuantitativo para reforzar el análisis que se centra en lo cualitativo. Se eligió un tipo de investigación preponderantemente cualitativa, en tanto se reconoce la importancia de analizar las realidades sociales desde su complejidad, situándolas en el contexto particular del que hacen parte (Dugarte, 2006). Adicional a ello, este trabajo es principalmente cualitativo porque tiene muy en cuenta las redes de significados que dan los sujetos a sus experiencias y los contextos sociales, culturales e ideológicos a los que pertenecen (Dugarte, 2006).

El enfoque epistemológico de este trabajo es hermenéutico-interpretativo, porque la intención central fue interpretar cómo las representaciones sociales de los jóvenes están cargadas de unos significados e intencionalidades que interesa develar (Albert, 2007). Para hacerlo, se tuvo en cuenta que la conciencia humana es ante todo histórica y sociocultural, siendo su principal vehículo el lenguaje (Albert, 2007). Esta claridad tiene mucha importancia porque se parte de que las representaciones que tienen los jóvenes sobre la realidad, están enmarcadas dentro de un contexto social e histórico. 
Como la intención fue realizar un acercamiento a la comprensión de los sentidos de las representaciones sociales acerca de la estética que tienen los jóvenes participantes en la investigación, se recurrió a la hermenéutica. Entendiendo por hermenéutica al paradigma desde donde es posible comprender ciertos fenómenos a través de un complejo proceso de pensamiento (Dilthey,1997).

La comprensión se entiende como el proceso de llegar al significado, desde un punto de vista histórico, en donde la experiencia vivida es siempre temporal y moldeada por un contexto que va del pasado al futuro (Dilthey,1997). Otra de las perspectivas sobre la hermenéutica que fundamenta este trabajo es la desarrollada por Ricoeur (2001), quien plantea que la unidad básica a la hora de analizar un texto, se encuentra en el lenguaje y en el texto mismo. Por lo que, para llegar a comprender, primero debemos leer los textos movilizándonos hacia los significados que estos nos plantean. Con relación a la interpretación de los textos producidos por los jóvenes investigados, se retoman las ideas de Gadamer (2007) y Ricoeur (2001) acerca de cómo a la hora de interpretar, el lector lo hace desde un lugar específico que corresponde a su historicidad. Lo que da implícitamente al investigador un lugar más activo al acercarse a un texto porque al interpretar, revive las experiencias de quien generó el texto sin pretender llegar a un significado final u objetivo (Gadamer ,2007; Ricoeur ,2001). Idea que corresponde con la intencionalidad de comprensión de las representaciones que da lugar a este estudio, en donde se pretendió comprender los sentidos de las representaciones sociales de los jóvenes, desde una perspectiva dialógica entre las concepciones del investigador, la teoría y la práctica. 


\subsection{Método de investigación}

En esta investigación se eligió el estudio de caso. Se consideró adecuada esta elección porque permite estudiar los fenómenos desde diferentes perspectivas, teniendo en cuenta más de una variable. Adicional a ello, porque admite explorar a fondo los fenómenos estudiados (Chetty ,1996 en Martínez, 2006), específicamente los sociales, complejos por naturaleza.

Además, el estudio de caso tiene la característica de permitir que los datos puedan ser obtenidos desde fuentes diversas, tanto cualitativas como cualitativas, tales como entrevistas, archivos documentales, observaciones directas (Chetty ,1996 en Martínez, 2006), lo que facilita contrastar diferentes fuentes de información con el fin enriquecer el análisis aportado.

Este trabajo sería un estudio de caso, porque se centra en un grupo específico de jóvenes y las significaciones que manifiestan frente al fenómeno estudiado. Para hacerlo, se trabajó con los significados que los jóvenes de la muestra dan a algunos indicadores corporales y que aparecen en sus fotos de perfil en Facebook, insumos que después el investigador analizó para encontrar, describir, analizar y comprender los sentidos de esas representaciones. En este proceso se tuvieron en cuenta las especificidades del grupo seleccionado, pero se espera que algunas de las conclusiones a las que dé lugar la investigación, puedan ser replicadas en otros contextos con condiciones sociales y culturales similares (Yin, 1984) siendo esta una de las características de dicho método. 


\subsection{Técnicas de investigación}

En primer lugar, cabe anotar que antes de aplicar las tres técnicas de investigación principales escogidas para este estudio: grupo focal, entrevista semiestructurada y diario de campo, se llevó a cabo con el grupo de 30 jóvenes, una técnica conocida como Brainstorming que consiste en una técnica de entrevista grupal en donde a partir de una idea general, concepto, o pregunta, se generan nuevas ideas que van surgiendo a partir de la participación de los investigados.

Dicha técnica tuvo un carácter exploratorio y le apuntó al objetivo número uno: Identificar las representaciones sociales de la estética que tienen los jóvenes, manifestadas a partir los significados que dan a los indicadores corporales que muestran en sus fotos de perfil en Facebook, dado que se buscó identificar qué sentidos daban los jóvenes al concepto de estética, sin realizar aún en exploración más profunda.

Esta técnica permite a los participantes generar nuevas ideas informalmente, realizar conexiones de significados, otorgando importancia a la creatividad y al rol activo de los investigados (Toro, y Parra, 2010). Se utilizó dada la flexibilidad y facilidad que tiene para motivar la participación de los jóvenes.

\subsection{Grupo focal}

Esta técnica consiste en una entrevista grupal que, como su nombre lo indica, se focaliza en grupos de tres a diez personas. Ante todo, se busca generar una conversación entre los participantes a través de unas preguntas específicas, que, sin embargo, no descarta la posibilidad de que surjan nuevas preguntas o cuestiones a raíz de la discusión. 
De ahí que la interacción entre ellos pueda ser fluida. Dicho grupo de personas conversa a partir de un problema o pregunta teniendo en cuenta sus experiencias y creencias personales, siendo papel del investigador dirigir la conversación en relación con los temas que se estén desarrollando en la investigación (Hernández, 2010). Esta técnica le apuntó al objetivo número uno y dos, porque además de permitir identificar representaciones sociales (objetivo uno), también facilitó recoger datos para describir posteriormente esas representaciones (objetivo dos).

El estilo de conversación se da de manera semidirigida por parte del investigador. Este método se caracteriza porque da la posibilidad de que los participantes escuchen y discutan sus propias opiniones con las de los demás, aportando a cada persona nuevos puntos de vista, ayudando a que el tema sobre el que se está discutiendo pueda ampliarse más que en una entrevista individual (Albert,2006). La idea fue generar un ambiente de confianza, en donde los jóvenes pudieran expresar sus ideas, apoyar e incluso debatir las de los demás. Se escogió una muestra de cinco hombres y cinco mujeres de diferentes edades y con perfiles e intereses diferentes $\left({ }^{2}\right)$, pues la heterogeneidad del grupo seleccionado beneficia que se pueda abarcar más puntos de vista sobre la cuestión a discutir (Albert,2006). Lo que resulta fundamental para poder dilucidar los datos necesarios para abordar los objetivos uno y dos de este trabajo.

\footnotetext{
${ }^{2}$ Tener en cuenta que la investigadora es docente de este grupo de jóvenes estudiantes desde hace dos años, lo cual facilitó reconocer diferentes perfiles en relación con gustos y personalidades de cada uno.
} 


\subsection{Entrevista semiestructurada}

En conexión con el grupo focal expuesto antes, se complementa diciendo que la entrevista aplicada a dicho grupo fue semiestructurada. Esta consiste en una conversación entre el entrevistador y el entrevistado. Se caracteriza porque parte de unas preguntas que son desarrolladas con el fin de ampliar el tema que se esté investigando a partir de las concepciones, opiniones e intervenciones de la persona entrevistada (Hernández et al., 2010). Es una técnica muy útil para realizar investigaciones sociales, porque permite conocer algunas de las categorías y significados que son manejados por los sujetos estudiados. "En general una entrevista es una estrategia que en términos generales puede definirse como una conversación para hacer que la gente hable sobre lo que sabe, piensa y cree, una situación en la cual una persona obtiene información sobre algo interrogando a otra” (Toro y Parra, 2009, p.349). Se escogió porque se considera que, a través del diálogo, pueden obtenerse algunos datos importantes que pueden surgir a través de generar en los jóvenes la confianza de expresar abiertamente sus ideas. Lo anterior para que el investigador pueda profundizar no solo en la identificación de algunas de las representaciones sociales de los jóvenes (objetivo uno), sino poder realizar una descripción de esas representaciones (objetivo dos) a través de los detalles que pueden recogerse.

Como el tipo de entrevista que se utilizó fue semiestructurada y grupal, se aplicó motivando a los jóvenes a la participación e interacción entre ellos y con la investigadora, quien tenía el rol de moderar la sesión y, de ser preciso, formular nuevas preguntas que surgieran de la conversación misma. Se trata de una técnica en donde el investigador diseña unas preguntas, las aplica a la muestra, pero este guion es susceptible de ser 
modificado a medida que las personas entrevistadas van abarcando otros aspectos (Toro y Parra, 2009). Es decir, quien investiga cuenta con un listado de preguntas que apuntan a desarrollar lo mejor posible el tema y problema que se da origen a la investigación, pero permite cierta flexibilidad a los participantes en el momento en que contestan (Hernández et al., 2010), pues de ese ejercicio de distanciarse un poco de las preguntas preliminares, puede obtenerse información valiosa.

La entrevista se hizo grupalmente a 10 a jóvenes de la muestra de 30, con los que se estaba trabajando el resto de actividades. 5 hombres y 5 mujeres. Se eligieron de acuerdo a el interés que demostraron en querer seguir profundizando en la investigación de la que hacían parte. Dicha entrevista tuvo una duración de hora y media y se realizó en un salón de clases del colegio Fernando González Ochoa, institución educativa en donde estudian los jóvenes y en donde la investigadora es una de las docentes que les da clase. Las preguntas que se realizaron fueron las siguientes:

Tabla 1 - Preguntas entrevista semiestructurada

\begin{tabular}{|c|c|}
\hline $\begin{array}{l}\text { Número de } \\
\text { pregunta }\end{array}$ & Preguntas \\
\hline \# 1 & $\begin{array}{l}\text { ¿Qué criterios tienes en cuenta para publicar una foto de perfil en Facebook con } \\
\text { relación a la ropa, accesorios y posturas corporales? }\end{array}$ \\
\hline \# 2 & $\begin{array}{l}\text { ¿Qué motivaciones tienes para publicar fotos de perfil con los criterios de la } \\
\text { pregunta anterior? }\end{array}$ \\
\hline \# 3 & $\begin{array}{l}\text { ¿Qué herramientas de la plataforma de Facebook, específicamente las } \\
\text { relacionadas con la foto de perfil, te permiten saber si tus fotos han gustado a los } \\
\text { demás? }\end{array}$ \\
\hline \# 4 & ¿ Cómo te afecta a ti la reacción de los demás frente a tus fotos de perfil? \\
\hline \# 5 & $\begin{array}{l}\text { ¿Qué tipo de ropa, accesorios y posturas corporales no consideras estéticas para } \\
\text { mostrar en tus fotos de perfil en Facebook? ¿Por qué? }\end{array}$ \\
\hline \# 6 & $\begin{array}{l}\text { ¿Cómo ha sido tu experiencia personal en Facebook en relación a la forma en } \\
\text { que presentas tus fotos de perfil, específicamente a partir de la ropa, accesorios } \\
\text { y posturas corporales que muestras en ellas? }\end{array}$ \\
\hline \# 7 & ¿Tienes un modelo a seguir cuando elaboras una foto de perfil en Facebook, \\
\hline
\end{tabular}


específicamente en relación con la ropa, accesorios y posturas corporales que muestras en ellas? Explica ampliamente por qué.

\# 8 ¿Qué relación tiene la apariencia física que muestras en tus fotos de perfil en Facebook con la ropa, accesorios y posturas corporales que usas en ellas?

\# 9 ¿Crees que es importante tener alguna estrategia para lucir mejor en tus fotos de perfil en Facebook, específicamente en relación a ropa, accesorios y posturas corporales? ¿Por qué?

\# 10 Si tienes una estrategia para lucir mejor en tus fotos de perfil ¿Cuál o cuáles son esas estrategias? ¿Por qué consideras que puede(n) funcionar?

\subsection{Observación participante}

En este estudio la observación se concibe como una técnica complementaria que permite recoger datos extra con relación a las descritas anteriormente. Se trata de una estrategia de recolección de datos que implica sumergirse en las situaciones sociales que se están analizando, manteniendo un rol activo, pues el investigador asume un rol real dentro de la institución o grupo que está observando (Albert, 2007). Lo cual ocurre precisamente en este trabajo porque el investigador es docente de los jóvenes de la muestra, lo que implica que los talleres y actividades que se desarrollaron dentro del estudio, fueron dirigidos por el investigador mismo. Dicha técnica se aplicó en conexión con los tres objetivos específicos de esta investigación, en tanto aparece en cada uno de los métodos y herramientas utilizadas, a través de comentarios que se hacen en las matrices de sondeo, entrevistas y diarios de campo especialmente. Lo anterior, dado que la observación y su registro es una buena herramienta para ayudar en la identificación, descripción y análisis (Albert, 2007) de las representaciones sociales de los jóvenes en que nos centramos.

La observación participante "se trata de una técnica de recolección de datos que tiene como propósito explorar y describir ambientes. No se trata de una mera contemplación, 
implica a adentrarse en profundidad en situaciones sociales y mantener un rol activo" (Albert, 2007, p.232). Al no ser solo observación de una situación, esta técnica permite al investigador implicarse en la vida y cultura del grupo para lo cual se pueden analizar variedad de cosas, por ejemplo: documentos, las entrevistas realizadas a los participantes, así como las reflexiones que sean producto de la introspección del observador (Denzin, 1978 en Albert, 2005). Lo anterior permite que los diarios de campo, técnica que describiremos a continuación, pueda incluir no solamente las observaciones de hechos particulares que hayan ocurrido en un momento determinado, sino los análisis que se derivan de la aplicación de cada método e instrumento de investigación.

Para la observación participante se tuvieron en cuenta los sucesos y análisis de datos de: taller 1 (sondeo exploratorio), sesión de discusión con el grupo focal, entrevistas semiestructuradas, y los dos talleres en que se aplicaron los dos instrumentos: cuadro de elementos significativos y mapa semántico. El registro de esas observaciones se llevó a través de unos formatos de diario de campo.

\subsection{Diario de campo}

El diario de campo es un método que permite la recolección de datos que se obtienen a través del registro de los ambientes naturales. Se trata del análisis de los significados que se pueden capturar al tratar de develar cómo se dan las interacciones entre los grupos, su forma de organización y códigos de sentido (Hernández, 2010). Dicho método es utilizado en este estudio porque permite capturar información que resulta no solamente de la observación participante, sino las anotaciones que hizo el investigador durante las sesiones 
de trabajo con los jóvenes, así como las reflexiones que esos datos suscitaron y que enriquecen el proceso de interpretación.

Dicho método incluye no solamente el registro de los hechos, sino las anotaciones personales del investigador, sus sentimientos, actitudes, análisis y comentarios (Albert, 2007). Así mismo deberá incluir de manera secuenciada y con fecha y hora los periodos de tiempo en que se llevaron a cabo las observaciones, lo que facilitará la presentación y análisis de la información (Albert, 2007). De ahí que se diseñó una matriz o formato en donde se registraron los diarios de campo que se llevaron a lo largo de esta investigación $\left(^{3}\right)$. Los diarios de campo se realizaron con cada una de las actividades que se aplicaron con los jóvenes, las cuales se llevaban a cabo cada dos semanas a partir del mes de mayo de 2017 hasta el 29 de agosto del mismo, siendo desarrollados cuatro en total $\left({ }^{4}\right)$.

\subsection{Instrumentos de investigación}

De acuerdo al método que propone Abric (2001) para hallar representaciones sociales de los sujetos investigados, en donde a partir de una asociación libre de conceptos que hacen los participantes, es posible identificar tanto el núcleo como los elementos periféricos de las representaciones sociales, se plantearon tres instrumentos de investigación que son: cuestionario de preguntas abiertas (sondeo exploratorio), cuadro de elementos significativos y mapa semántico $\left(^{5}\right)$. El primero de ellos es un formato en donde aparecen cinco preguntas con espacio para que el joven las conteste en la parte inferior de

\footnotetext{
${ }^{3}$ Los diarios de campo pueden observarse en el anexo $\mathrm{C}$.

${ }^{4}$ Las fechas exactas de registros en el diario de campo, se encuentran especificadas en el formato que se diseñó para este fin y se puede encontrar en el anexo C

${ }_{5}^{5}$ Dichos instrumentos se pueden encontrar en los anexos D, E y F, de acuerdo al orden en que fueron mencionados.
} 
las mismas, en un espacio destinado para tal fin y se aplicó como parte de un taller posterior a la socialización de un video relacionado con Facebook y la foto de perfil. El segundo, es un formato tipo cuadro, en donde los jóvenes registraron los significados que le daban a mínimo 10 elementos importantes para ellos en sus fotos de perfil y que se conecten con los indicadores corporales que, para ellos, sean más relevantes (tales como ropa, accesorios, gestos, posturas, entre otros). Lo anterior se hizo al interior de un taller que se llevó a cabo en una de las sesiones y que tuvo dos horas de duración. Este instrumento apuntó principalmente al abordaje del objetivo número uno y dos de este trabajo, porque al leer y analizar el contenido con que los jóvenes completaron este cuadro, fue posible identificar algunas categorías y subcategorías que dieron pistas sobre el tipo de representaciones sociales que tienen los jóvenes acerca de la estética, así como algunas ideas que permitieron empezar a describirlas.

El esquema o mapa semántico se utilizó posteriormente en el segundo taller que también tuvo una duración de dos horas. En este instrumento, los estudiantes debían completar un mapa semántico cuyo núcleo era la palabra estética. Cada joven debía completar el mapa usando conceptos centrales y periféricos. Tenían que partir de la palabra central, en relación con los significados que daban a los indicadores corporales que usualmente muestran en sus fotos de perfil en Facebook. Dicho instrumento y cómo fue su aplicación se amplía más adelante cuando se describa cada fase de esta investigación en cuanto a su metodología. 


\subsection{Unidad de análisis}

Esta investigación fue desarrollada entre el primer y segundo semestre de 2017 con jóvenes estudiantes de grado octavo del colegio distrital Fernando González Ochoa de la jornada mañana, ubicado en la localidad de Usme en la cuidad de Bogotá. El rango de edades de dichos jóvenes está entre los 14 y 17 años. Cabe anotar que, en este caso, el investigador tiene acceso constante para interactuar con los jóvenes con quienes se realizó este trabajo, en tanto es docente de lengua castellana en esta institución.

\subsection{Contextualización de los jóvenes de la investigación}

La institución educativa en donde estudian los jóvenes participantes está ubicada en la parte más central de la localidad (Virrey), lo cual beneficia a los habitantes del barrio, quienes tienen acceso a mejores infraestructuras, transporte, en comparación con quienes viven más en la periferia de la localidad. Se trabajó con un total de 30 jóvenes, 15 hombres y 15 mujeres.

Dichos jóvenes se caracterizan por pertenecer a estratos socioeconómicos que oscilan entre el 1 y el 2, de acuerdo a datos institucionales de las Secretarias de Salud y de Ambiente de la Alcaldía Mayor de Bogotá (2009) (Observatorio De Desarrollo Económico, 2015). Algunos de los barrios aledaños al colegio son invasiones; otros que no lo son, cuentan con los servicios básicos como: agua, electricidad y alcantarillado, y, en varios casos, internet, según lo señalan algunos de los jóvenes. 
Algunas las problemáticas más sobresalientes en esta localidad tienen que ver con la pobreza, el pandillismo, la drogadicción y la inseguridad, según lo que se observa en los alrededores y de acuerdo a lo que expresan los mismos jóvenes.

La mayoría de los jóvenes investigados vive en condiciones de pobreza, que, aunque no es extrema, sí se manifiesta en gran parte de las familias. La mayoría cuenta con acceso a internet en sus hogares o en establecimientos comerciales en el barrio. Todos los jóvenes que participaron tienen una cuenta en Facebook, siendo usuarios activos en esta plataforma.

\subsection{Fases de la investigación}

\subsubsection{Fase uno: sondeo exploratorio. Instrumento 1.}

Actividad: taller

Duración: 2 horas

Fecha de aplicación: 17 de julio de 2017

Participantes: los 30 jóvenes de la muestra

Lugar: salón de audiovisuales I.E.D (polivalente) I. E.D Fernando González Ochoa.

En primer lugar, se realizó una sensibilización con los jóvenes, que implicó observar y discutir un video $\left(^{6}\right)$ sobre cómo Facebook se ha ido convirtiendo en un medio para socializar cómo ha cambiado la manera en que muchas personas se relacionan con otras. Posterior a ello, se formularon algunas preguntas que indagaban sobre qué significaba para

\footnotetext{
${ }^{6}$ Este video se titula: "El autoengaño de una vida falsa en Facebook" y puede encontrarse su referencia en la bibliografía.
} 
ellos la palabra estética y si la conectaban de alguna manera con sus fotos de perfil en Facebook, específicamente en relación con los indicadores corporales que muestran en ellas, tales como: ropa, accesorios, posturas corporales( $\left.{ }^{7}\right)$.

Posterior a ello, se aplicó un brainstorming. Allí se instó a los jóvenes a dar palabras con las que ellos conectaran a la estética. Después se les preguntó qué palabras estarían más alejadas de dicho concepto. La investigadora iba escribiendo en un tablero los conceptos que iban emergiendo y organizándolos de acuerdo al orden de importancia que los mismos jóvenes iban señalando en relación a la palabra principal (estética).

Este sondeo exploratorio tuvo como objetivo realizar un acercamiento a las concepciones de los jóvenes frente a la estética y a la conexión que le dan con las fotos de perfil en Facebook. De ahí que se vincule con el objetivo número uno de este trabajo.

\subsubsection{Fase dos. Taller. Instrumento 2.}

Instrumento aplicado: cuadro de elementos significativos $\left(^{8}\right)$

Duración: 2 horas

Participantes: los 30 jóvenes de la muestra

Fecha de aplicación: 1 de agosto de 2017

De acuerdo con el objetivo número uno de esta investigación, se identificó qué conceptos encuentran más significativos en relación con lo estético los jóvenes en sus

\footnotetext{
${ }^{7}$ Las preguntas y principales respuestas que dieron los jóvenes en este sondeo se encuentran registradas en el anexo A.

${ }^{8}$ Este instrumento se puede observar en el anexo E.
} 
fotos de perfil en Facebook. Para hacerlo, se les propuso un instrumento tipo cuadro $\left({ }^{9}\right)$, en donde a partir de diez fotografías de sus perfiles, debían seleccionar los accesorios, posturas corporales y ropa que consideraran los hacen lucir bellos en esas fotos. En este punto se trabajó con la palabra belleza como sinónima de estético de acuerdo a los resultados obtenidos en el sondeo exploratorio.

La idea era que trataran de encontrar como mínimo cinco elementos en cada fotografía, aunque si encontraban más, podían agregarlos al cuadro. En esta fase se trataba de definir los componentes que constituyen a las representaciones de los jóvenes acerca de la estética. Es decir, se buscó encontrar el contenido de las representaciones a partir de los elementos que las constituyen (Abric,2001).

\subsubsection{Fase tres. Instrumento 3: mapa semántico}

Actividad: taller

Instrumento aplicado: esquema de mapa semántico $\left({ }^{10}\right)$

Duración: 2 horas

Participantes: los 30 jóvenes de la muestra

Fecha de aplicación: 15 de agosto de 2017

Se elaboraron mapas semánticos $\left({ }^{11}\right)$ con los jóvenes para establecer las relaciones, jerarquías y conexiones de sentido entre las categorías halladas en la fase anterior, para

\footnotetext{
${ }^{9}$ En el anexo G, se pueden encontrar algunos ejemplos de cuadros diligenciados por jóvenes participantes.

${ }^{10} \mathrm{El}$ esquema de este instrumento se puede revisar en el anexo $\mathrm{F}$

${ }^{11}$ En el anexo $\mathrm{H}$, se encuentran ejemplos de los mapas completados por los jóvenes.
} 
llegar a identificar el núcleo central de cada representación y cómo este se conecta con los elementos que la constituyen Abric (2001).

En este paso se pidió a cada uno de los jóvenes que pensara y escribiera cinco palabras o aspectos con relación a la estética, específicamente los que tienen en cuenta en sus fotos de perfil en Facebook y que tengan conexión con las posturas corporales, ropa y accesorios que muestran esas fotos (primer nivel del mapa). Después, debían escribir tres o más palabras con que asociaran cada uno de los elementos anteriores (segundo nivel del mapa). En un tercer nivel, el joven debía escribir dos o más palabras que tuvieran conexión con cada uno de los aspectos que iban saliendo a flote y que se organizaron jerárquicamente desde los más generales, hasta los más específicos.

La idea era formar un esquema tipo mapa semántico, cuyo concepto central era la palabra estética, del que partían otras asociaciones. Se entregó una plantilla que los jóvenes debían completar, pero se les hizo la aclaración de que podían agregar más palabras si así lo deseaban. La indicación que debían seguir era que en cada nivel del mapa debían regresar al eje central y hacer las conexiones partiendo siempre de este.

Se indicó a los jóvenes que, al realizar los mapas semánticos, tuvieran presente que el color en este tipo de organizadores gráficos es fundamental, porque permite diferenciar mejor el nivel al que pertenece cada concepto. Así mismo, el color permitió que se diferenciaran mejor los conceptos centrales (debían ir con tonos más oscuros) de los periféricos (que se debían presentar en tonos más claros). 


\subsubsection{Fase cuatro. Entrevista semiestructurada grupal}

Actividad: entrevista (semiestructurada) grupal (preguntas abiertas)

Duración: 1 hora y media

Fecha de aplicación: 29 de agosto de 2017

Participantes: 10 jóvenes de la muestra. 5 hombres y 5 mujeres( ${ }^{(2)}$

En un salón de clase del colegio Fernando González Ochoa, se convocó a diez jóvenes que, por voluntad propia y previo permiso de sus padres, accedieron a ser entrevistados de manera grupal. Se les realizaron diez preguntas abiertas que indagaron acerca de los criterios, motivaciones que tienen en cuenta en sus fotos de perfil en Facebook. Se realizaron también preguntas con las que se intentaba confirmar o desmentir la hipótesis de que, al elaborar una foto de perfil, los jóvenes tienen en cuenta aspectos estéticos. De la misma manera, se optó por formular interrogantes que tendían a averiguar cómo los elementos contextuales de la plataforma y del espacio virtual en que los jóvenes publican sus fotos de perfil se relacionaban con sus concepciones sobre lo estético.

Cada una de las preguntas trabajadas en esta entrevista buscó identificar las narrativas sobre las que se sustentan sus concepciones acerca de lo estético y, muy particularmente, con la relación entre estética y belleza, de acuerdo a los resultados preliminares que se fueron obteniendo a raíz de los métodos e instrumentos aplicados anteriormente. Otras preguntas trataron de profundizar en los aspectos biográficos y socioculturales de los jóvenes en relación con la estética y en la forma en que estos se vinculan con los

\footnotetext{
${ }^{12}$ Las edades de los jóvenes entrevistados, entre otros datos contextuales de los mismos, así como las preguntas y respuestas que dieron a cada una, se encuentran registradas en la matriz de preguntas y respuestas que se elaboró y se encuentra en el anexo B.
} 
significados que los jóvenes dan a ciertos indicadores corporales como: ropa, accesorios, gestos y posturas corporales en sus fotos de perfil. La entrevista se desarrolló grupalmente, con el fin de que se pudieran registrar las discusiones que surgieran entre los jóvenes a raíz de las preguntas abordadas.

La aplicación de estas entrevistas apuntó a los objetivos dos y tres de esta investigación, porque permitió no solo identificar categorías y subcategorías que permitieron encontrar las representaciones sociales de los jóvenes, sino porque al ser una técnica flexible en relación con la amplitud de aspectos que se pueden tener en cuenta en las preguntas y respuestas, fue de gran utilidad para realizar la descripción de dichas representaciones (objetivo dos). También se trató de explorar las categorías y subcategorías de análisis que se tuvieron en cuenta al elaborar los criterios de investigación propuestos $\left({ }^{13}\right)$

\subsubsection{Fase cinco. Análisis de información}

En esta parte del proceso, el investigador retomó sus anotaciones en los diarios de campo, contrastó la información obtenida a partir de las tres técnicas e instrumentos aplicados (triangulación), revisó la pertinencia de las categorías propuestas en los criterios de análisis, contrastó las categorías nuevas que emergieron a partir del análisis de los datos que se iba haciendo en las matrices con la teoría y, por último, redactó los resultados, conclusiones y recomendaciones.

Para el análisis de las representaciones sociales encontradas, se realizó un diálogo entre algunas de las teorías que se referenciaron en esta investigación, con los hallazgos obtenidos a partir de este trabajo. De ahí que en esta fase se haya abordado el objetivo

\footnotetext{
${ }^{13}$ Dichas categorías y subcategorías se encuentran en la tabla 2.
} 
número tres de esta investigación, que le apunta a este fin. Lo anterior, permitió enriquecer el análisis, generando un proceso dialógico entre la teoría y la práctica, aspecto que debe tener todo esfuerzo hermenéutico por comprender cualquier fenómeno (Gadamer, 2007). 


\section{Capítulo V. Resultados}

Después de analizar la información obtenida a partir de las técnicas e instrumentos descritos en la metodología, se encontraron algunas categorías y subcategorías. Para lograrlo, el principal procedimiento fue el de identificar las frases y palabras que más se repetían en las respuestas y textos escritos de los jóvenes.

La herramienta cuantitativa del programa de Microsoft Excel® sirvió para hallar los porcentajes en que cada joven mencionaba ciertas palabras que se conectan con algunas de las categorías centrales y subcategorías que se desarrollan en la tabla 2. En esta parte, no se tuvo en cuenta la cantidad de veces en que se repetía cada palabra por joven, sino la cantidad de jóvenes que la mencionaron, por lo menos una vez.

Esta herramienta facilitó este proceso porque permitió corroborar si los términos que resultaron del instrumento uno se repetían en este segundo instrumento, o si aparecían unas nuevas. Además, como el mapa semántico permite al joven realizar asociaciones libres, al igual que las cadenas asociativas de conceptos propuestas por Abric (2001), se pudo identificar no solo cuáles son elementos que constituyen a las representaciones sociales acerca de la estética, sino cómo estos se relacionan entre sí y su conexión con el eje central.

Observemos cómo se organizaron en interpretaron las categorías y subcategorías, las evidencias provenientes del trabajo de en campo y los análisis que resultaron al respecto: 


\subsection{Categorías y criterios de análisis}

Tabla 2

Categorías y criterios de análisis

\begin{tabular}{|c|c|c|c|c|}
\hline Categorías de análisis & Subcategorías & Criterios teóricos de análisis & $\begin{array}{c}\text { Evidencia de la información } \\
\text { recolectada }\end{array}$ & Análisis preliminar teoría-práctica \\
\hline Felicidad & Bienestar & $\begin{array}{l}\text { La felicidad o bienestar que se da } \\
\text { en la sociedad de consumidores es } \\
\text { aquella que está motivada por un } \\
\text { deseo jamás saciado de consumir } \\
\text { más objetos y servicios (Bauman, } \\
\text { 2007) } \\
\text { Es usual que los sujetos prefieran } \\
\text { mostrar en las fotos que suben a } \\
\text { las redes sociales momento de } \\
\text { bienestar (2003) } \\
\text { En la actualidad se tiende a } \\
\text { asociar el bienestar y la felicidad } \\
\text { humana con la capacidad para } \\
\text { consumir. (Chaparro, Echeverry, } \\
\text { Arévalo, 2014). }\end{array}$ & $\begin{array}{l}\text { Sonreí en esa foto porque quería } \\
\text { quedar bien. Me tomé la foto frente al } \\
\text { espejo para que se viera el celular que } \\
\text { es nuevo (recogida a partir del } \\
\text { instrumento 1). } \\
\text { Publiqué esa foto porque estaba feliz, } \\
\text { estábamos de viaje con mi familia en } \\
\text { Melgar y estaba estrenando ese } \\
\text { vestido y me pareció bonito y por eso } \\
\text { lo publiqué (joven mujer de } 14 \text { años) } \\
\text { (recogida a partir del instrumento } 1 \text { ). } \\
\text { Me saqué esa foto para mostrar las } \\
\text { gafas que había comprado...se me } \\
\text { miraban bien y quería que me las } \\
\text { vieran puestas (joven mujer de } 14 \\
\text { años) (Dato recogido a partir del } \\
\text { instrumento 1). }\end{array}$ & $\begin{array}{l}\text {-Las posturas corporales, accesorios, } \\
\text { filtros, fondos, emojis, son manejados } \\
\text { por muchos jóvenes al estilo receta. Si } \\
\text { se quiere parecer feliz, aparece por } \\
\text { ejemplo la sonrisa, fondos y filtros } \\
\text { luminosos con colores vivos, si se } \\
\text { quiere parecer triste, colores oscuros, } \\
\text { posturas corporales como mirar hacia } \\
\text { abajo, gestos con la boca o miradas } \\
\text { específicas. Se comparten unos códigos } \\
\text { que sirven a los jóvenes para proyectar } \\
\text { en sus fotos, aquello que les interesa en } \\
\text { el momento. Por lo general, existe una } \\
\text { tendencia a querer mostrarse felices, } \\
\text { por lo que se prefiere salir sonriendo, } \\
\text { bien sea con una sonrisa real o fingida } \\
\text { o mostrándose a sí mismos en } \\
\text { situaciones reconocidas socialmente } \\
\text { como agradables. De hecho, la mayoría } \\
\text { de jóvenes tiende a asociar a la sonrisa } \\
\text { con verse bien en una foto de perfil. } \\
\text { Aunque esto no ocurre en todos los } \\
\text { casos. Para algunos de ellos, es }\end{array}$ \\
\hline
\end{tabular}


En su mayoría los jóvenes optan por publicar fotos de perfil en donde se vean alegres o la estén pasando bien, a despecho de otras en donde aparezcan situaciones consideradas socialmente como desagradables (Morduchowicz, 2012)

Es recurrente una estetización de las fotos que fracturan la realidad, acorde con unos ideales de belleza que vienen dados de antemano Leo (en Fernández, Zelich y Monter ,2004)

Existe toda una estetización de la propia imagen en las fotografías. Por eso la gente juega todo el tiempo con dichas imágenes para acercarse a lo que se considera socialmente deseable (Doswald (en Fernández, Zelich 2004)
Tenía puestas las Nike y por eso me tomé la foto de cuerpo entero. Se me veían re cool y quería que mis amigos me los vieran (joven hombre de 15 años) (recogida a partir del instrumento 1).

Estaba viajando con mi familia feliz, habíamos comprado hamburguesas y yo extendí las manos porque me gustó como se veían desde el mirador. (hombre de 14 años. Instrumento 1)

Había comprado una chaqueta y quería que se me viera bien en la foto. También le puse un fondo llamativo ya que tiene un color llamativo. La chaqueta me hace ver la camisa mejor y también se ve la chaqueta mejor (hombre de 14 años. Instrumento 1).

Y sonreí porque quería salir bien en la foto. (hombre de 14 años. Instrumento $1)$. importante mostrar en sus fotos estados de ánimo que se conectan con vivencia y experiencias realmente significativas.

Existe un imperativo social en el que se considera adecuando compartir fotos en donde los sujetos aparecen en situaciones que les son favorables. En oposición a ello, cuando se presentan momentos adversos, parece ser que es mejor ocultarlos o simplemente no exponerlos a la mirada de los otros Implícitamente, se puede decir que el sujeto está impelido a demostrar públicamente que es feliz, que está bien, dejando para sí aquellos momentos en que no lo está. Lo que se puede conectar con las ideas de Bauman (2007) con relación al proyecto de vida consumista, en donde las personas lograrían su plenitud a través de capacidad para consumir. En la sociedad consumista se es feliz, pues aparentemente el mercado ofrece todas las posibilidades para serlo, siempre y cuando la persona sea un consumidor activo. Si no se alcanza ese bienestar que proporciona el mercado, es mejor que los demás no lo noten.

La belleza para buena parte de los

jóvenes, en la actualidad tiene más que ver con el parecer que con el ser bello.

La foto se vuelve un signo que remite a otros signos en el universo mediático.

Es más importante que la foto parezca 


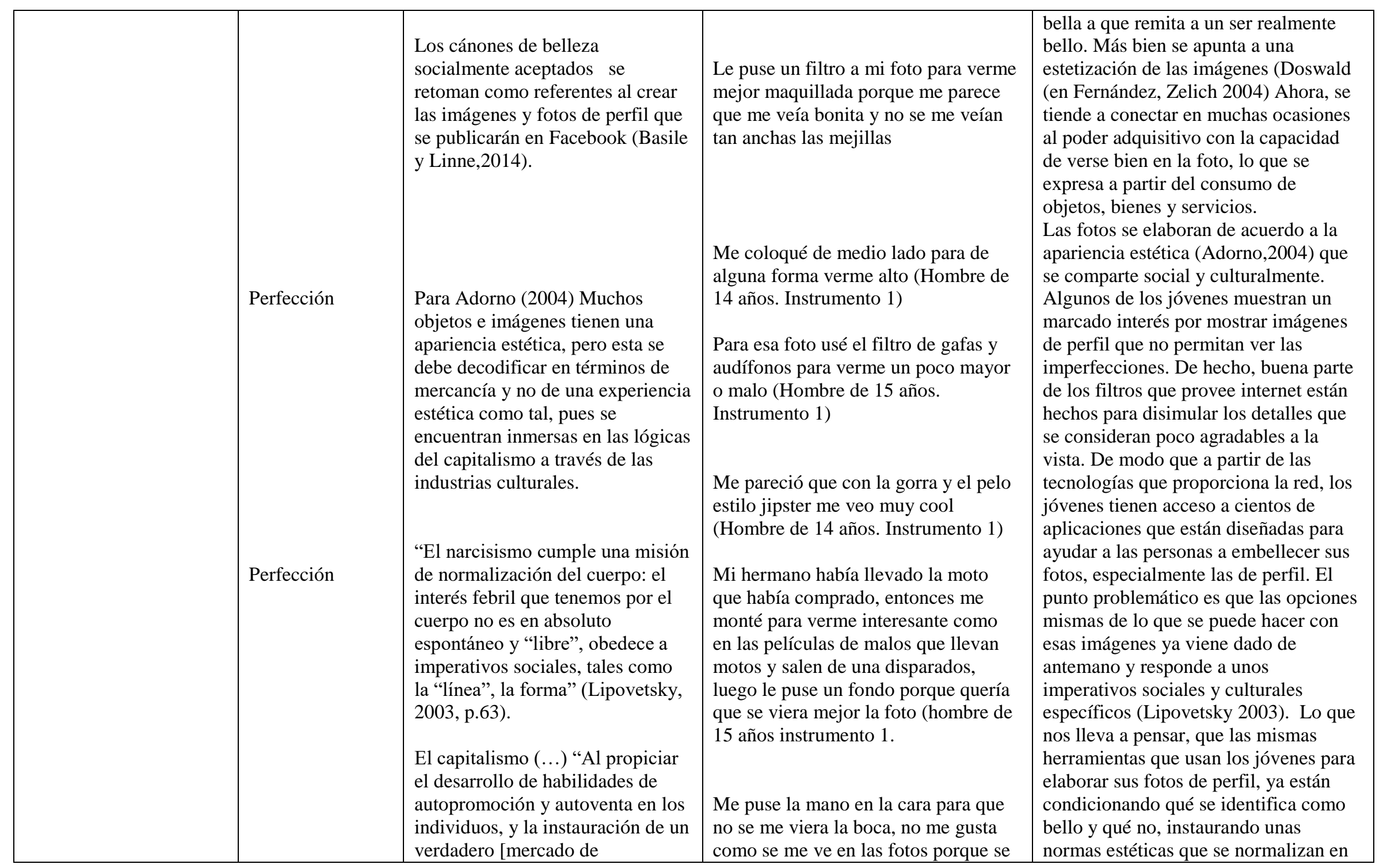




\begin{tabular}{|c|c|c|c|c|}
\hline Reconocimiento & Perfección & $\begin{array}{l}\text { personalidad], en el cual la } \\
\text { imagen personal es el principal } \\
\text { valor de cambio (Sibilia, 2008, } \\
\text { p.267). } \\
\text { Para Bauman (2007), el sujeto } \\
\text { mismo se convierte hasta tal punto } \\
\text { en mercancía, que asume la tarea } \\
\text { de convertirse en el objeto más } \\
\text { consumible posible, para lo que } \\
\text { busca acercarse a lo que podría } \\
\text { llegar a ser. Siempre en una } \\
\text { carrera desenfrenada hacia las } \\
\text { mejoras continuas de los cuerpos } \\
\text { que, sin embargo, nunca serán } \\
\text { suficientes para acercarse a los } \\
\text { cánones de belleza y perfección } \\
\text { que imponen los mercados. } \\
\end{array}$ & $\begin{array}{l}\text { ve como muy grande a veces (mujer } \\
\text { de } 14 \text { años). } \\
\text { Use ese labial porque me hace ver los } \\
\text { labios más gruesos y llamativos } \\
\text { (mujer de } 15 \text { años. Instrumento 1) } \\
\text { Me tomé esa foto porque me había } \\
\text { planchado el pelo y había usado un } \\
\text { labial bonito, entonces me veía bonita } \\
\text { y me saqué la foto y ya y la publiqué } \\
\text { (Mujer de } 16 \text { años. Instrumento } 1 . \\
\text { Me tomé la foto de cuerpo entero } \\
\text { porque quería que resaltara la cola y } \\
\text { la ropa que tenía era bonita y quería } \\
\text { que se me viera en la foto (mujer de } \\
\text { 17 años. Instrumento } 1 \text { ) } \\
\text { La estética o belleza es ser uno mismo } \\
\text { en las fotos, no poner tantos filtros o } \\
\text { editar, estar cómodos con nosotros. } \\
\text { (Mujer de } 14 \text { años. Sondeo } \\
\text { exploratorio) } \\
\text { Siempre uso muchos fondos en mis } \\
\text { fotos para que no sean como tan } \\
\text { simples, también busco aplicaciones } \\
\text { para poner orejas de animales tiernos } \\
\text { o maquillaje que me haga resaltar la } \\
\text { cara sobre todo como las de Snapchat } \\
\text { (mujer de } 16 \text { años) (dato obtenido en } \\
\text { entrevista) }\end{array}$ & $\begin{array}{l}\text { lo cotidiano. } \\
\text { El sujeto a través de sus fotos se va } \\
\text { convirtiendo en una mercancía Bauman } \\
\text { (2007). De ahí que sea preciso hacerlas } \\
\text { más atractivas para el mercado. El } \\
\text { joven, por lo general, optará por hacer } \\
\text { mejoras a su perfil, de acuerdo a las } \\
\text { exigencias cada vez más demandantes } \\
\text { del medio. } \\
\text { De hecho, se puede inferir de las } \\
\text { intervenciones de algunos jóvenes, que } \\
\text { las fotos simples o no muy elaboradas } \\
\text { (a través de las poses, uso de ropa, } \\
\text { gestos y, muy especialmente, fondos y } \\
\text { filtros), se consideran poco atractivas. } \\
\text { De todas maneras, existen entre los } \\
\text { jóvenes otras concepciones acerca de lo } \\
\text { que significa la estética, que no se } \\
\text { limitan a la apariencia física. Lo que } \\
\text { lleva a pensar en que es inadecuado } \\
\text { generalizar que los jóvenes únicamente } \\
\text { conecten estética con verse bellos, } \\
\text { particularmente en sus fotos de perfil. }\end{array}$ \\
\hline
\end{tabular}




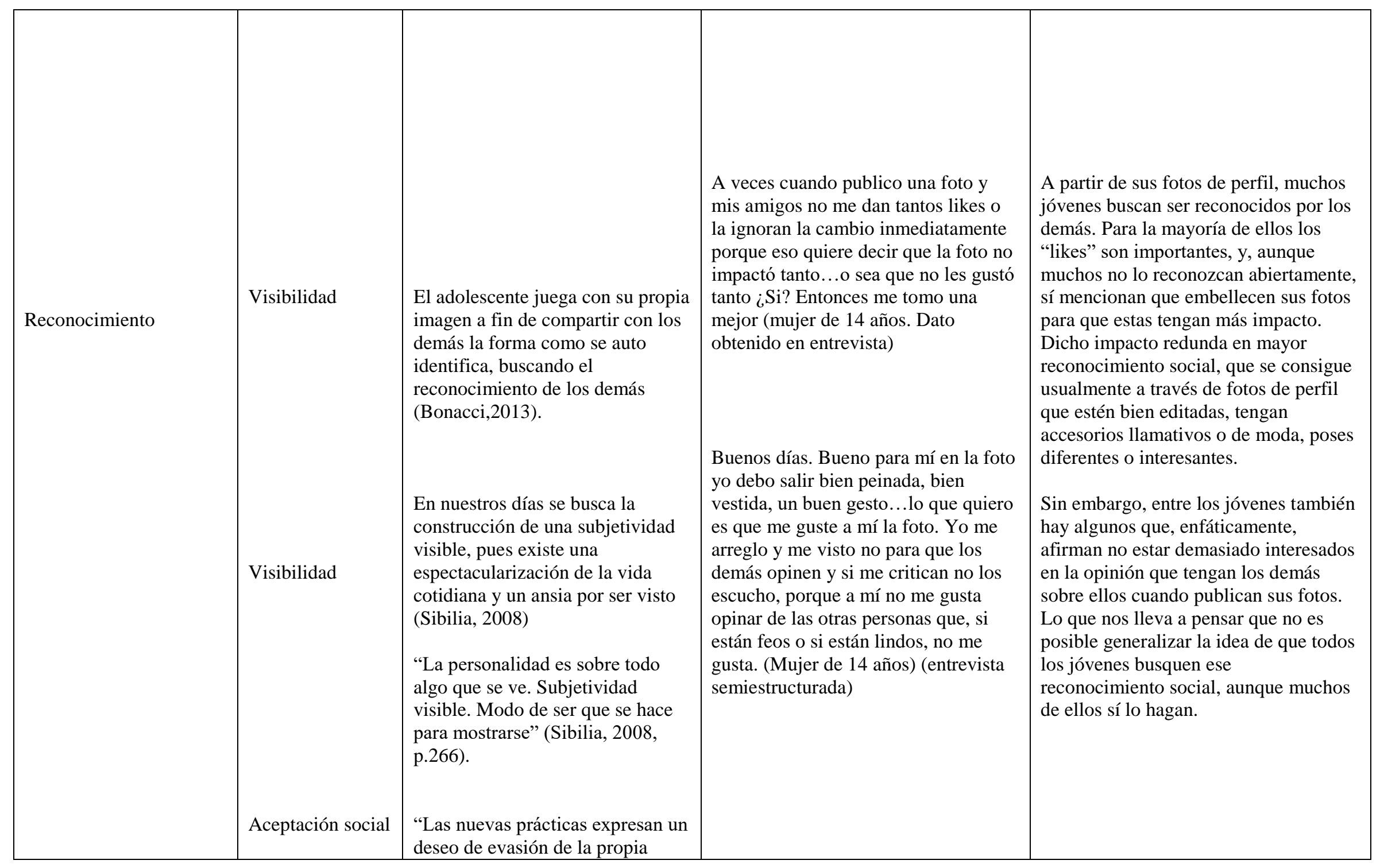




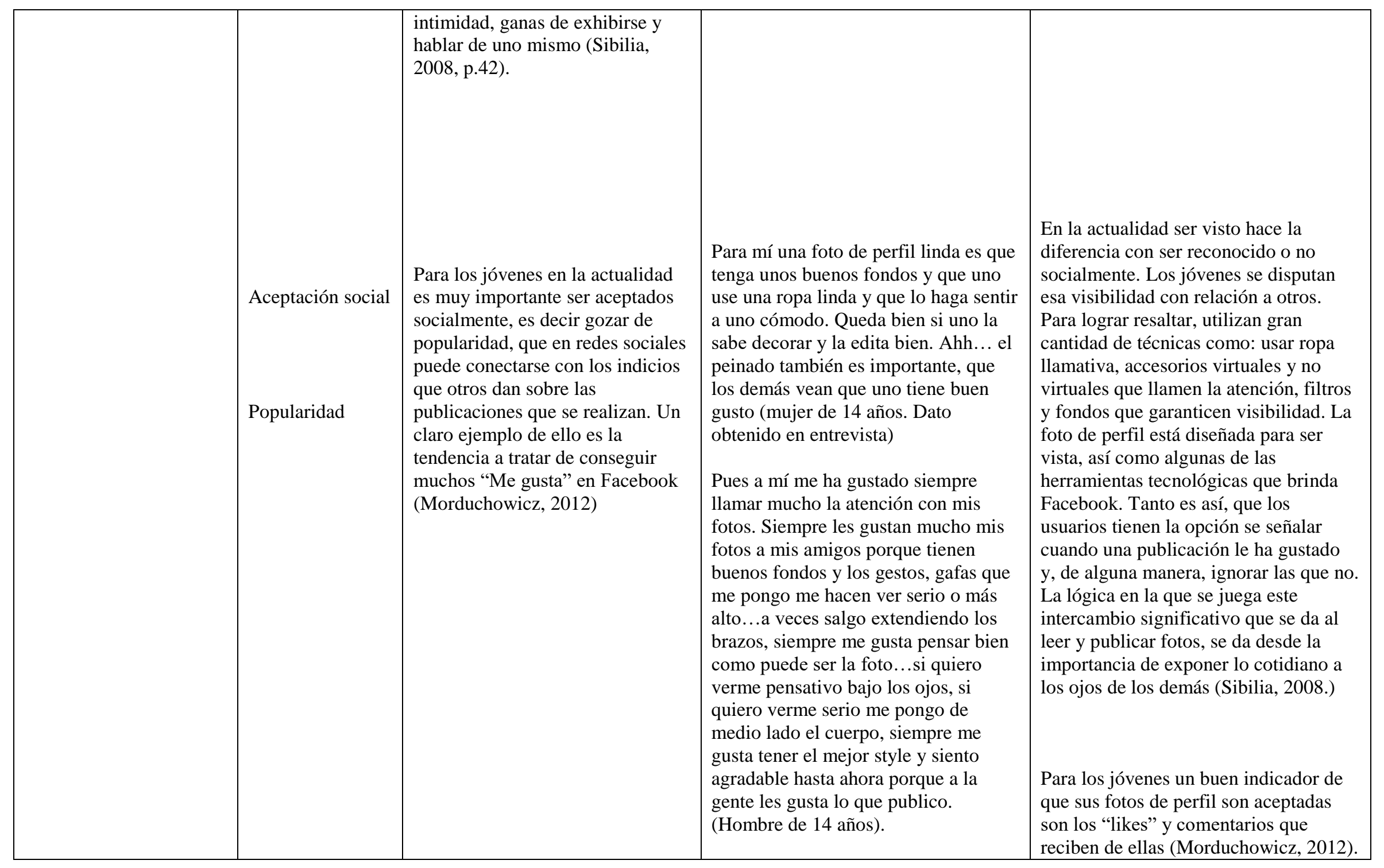




\begin{tabular}{|c|c|c|c|c|}
\hline Personalización & Diferenciación & $\begin{array}{l}\text { Hoy en día en día se da un } \\
\text { proceso de personalización en } \\
\text { donde se promulga la idea de que } \\
\text { cada uno debe buscar la } \\
\text { autenticad, estar más en contacto } \\
\text { consigo mismo, elegir libremente. } \\
\text { Sin embargo, las opciones sobre } \\
\text { las cuales elegir vienen dadas de } \\
\text { antemano desde la sociedad } \\
\text { consumista (Lipovetsky, 2003) } \\
\text { Existe un (...) "proceso } \\
\text { sistemático de personalización } \\
\text { que consiste esencialmente en } \\
\text { multiplicar y diversificar la oferta, } \\
\text { en proponer más para que uno } \\
\text { decida más, en sustituir la } \\
\text { sujeción uniforme por la libre } \\
\text { elección, la homogeneidad por la } \\
\text { pluralidad, la austeridad por la } \\
\text { realización de los deseos" } \\
\text { (Lipovetsky,2003, p.19). } \\
\text { Se da (...) "la obligación de ser } \\
\text { singular, y de que esa originalidad } \\
\text { individual esté a la vista. Con este } \\
\text { fin el propio cuerpo se vuelve un } \\
\text { objeto de diseño, un campo de } \\
\text { auto creación capaz de permitir la }\end{array}$ & $\begin{array}{l}\text { Me tomé la foto de medio cuerpo } \\
\text { porque quería que resaltara y que me } \\
\text { vieran todo el cuerpo. La sonrisa fue } \\
\text { para que los labios se vieran mejor. } \\
\text { Las candongas y el filtro B612 fue } \\
\text { para mejorar la foto y ganarme más } \\
\text { likes (Mujer de } 16 \text { años. Dato } \\
\text { recolectado con el instrumento } 1 . \\
\text { Para mí la belleza es mirarse y no } \\
\text { mirar tanto tus imperfecciones sin } \\
\text { importar lo comenten y si les gusta } \\
\text { (mujer de } 14 \text { años) (entrevista } \\
\text { semiestructurada) } \\
\\
\text { Use esa expresión en la cara porque } \\
\text { quería que la foto quedara rara } \\
\text { (Hombre de 14 años. Instrumento 1) } \\
\\
\text { Me puse el pelo al lado porque quería } \\
\text { que la foto saliera distinta. También } \\
\text { usé un fondo de colores y le puse } \\
\text { unos aretes a la foto porque así se veía } \\
\text { con mi propio gusto (mujer de } 14 \\
\text { años. Instrumento 1) }\end{array}$ & $\begin{array}{l}\text { No obstante, lo anterior no implica que } \\
\text { otros jóvenes dejen de tener otras } \\
\text { motivaciones que respondan a lógicas } \\
\text { diferentes a llamar la atención de los } \\
\text { demás. Algunos de ellos expresan que } \\
\text { sus motivaciones son más bien de } \\
\text { carácter personal y responden a unas } \\
\text { sensibilidades alejadas de ser populares } \\
\text { u obtener likes en Facebook. } \\
\text { La mayoría de los jóvenes busca } \\
\text { desmarcase de los demás, dejar su } \\
\text { huella, verse distintos para ser } \\
\text { reconocidos. De ahí que se esfuercen } \\
\text { por personalizar sus perfiles en } \\
\text { Facebook. Lo curioso, es que resulta } \\
\text { complicado salirse de los parámetros } \\
\text { que la misma plataforma da sobre cómo } \\
\text { personalizar los perfiles. De hecho, no }\end{array}$ \\
\hline
\end{tabular}




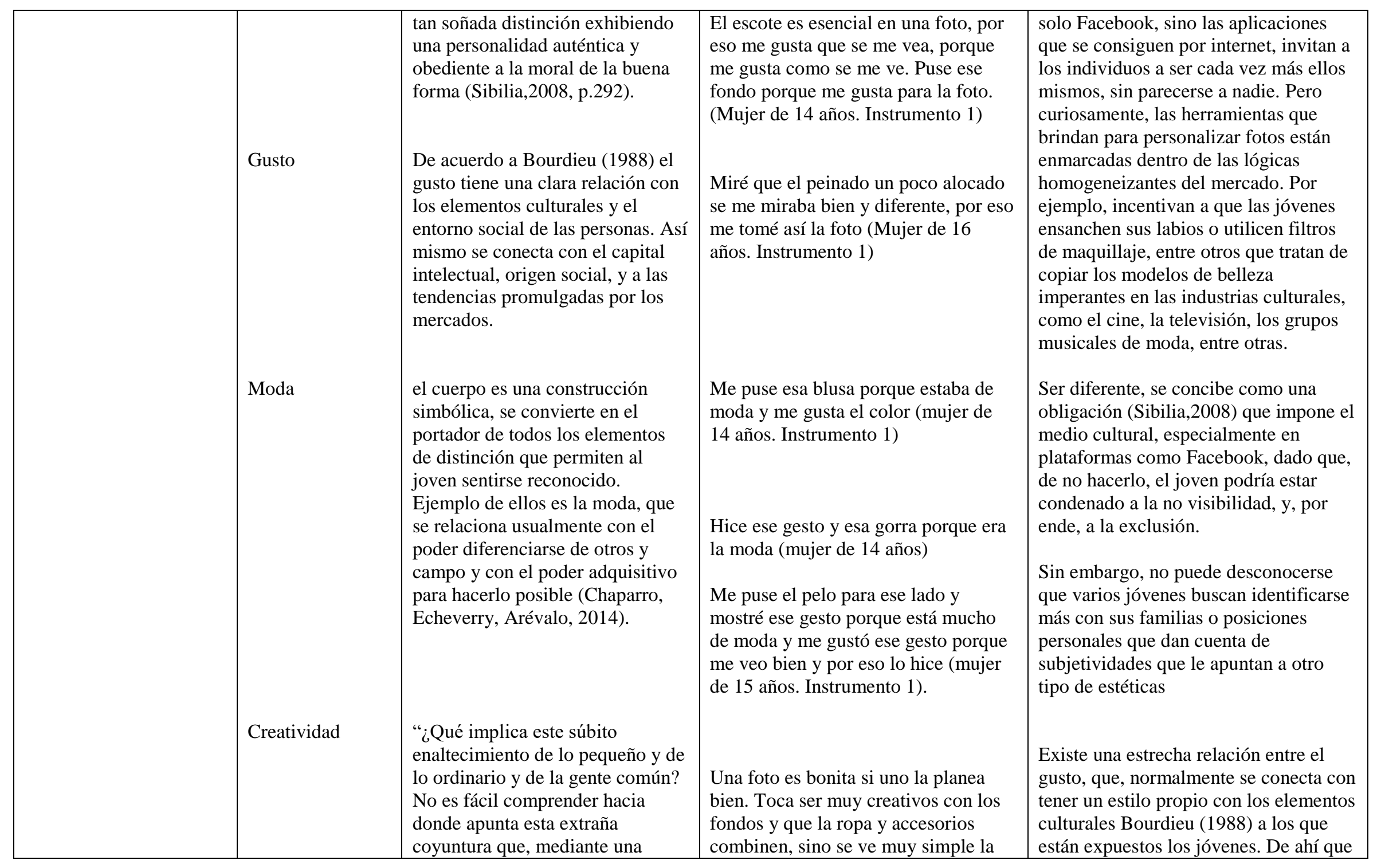




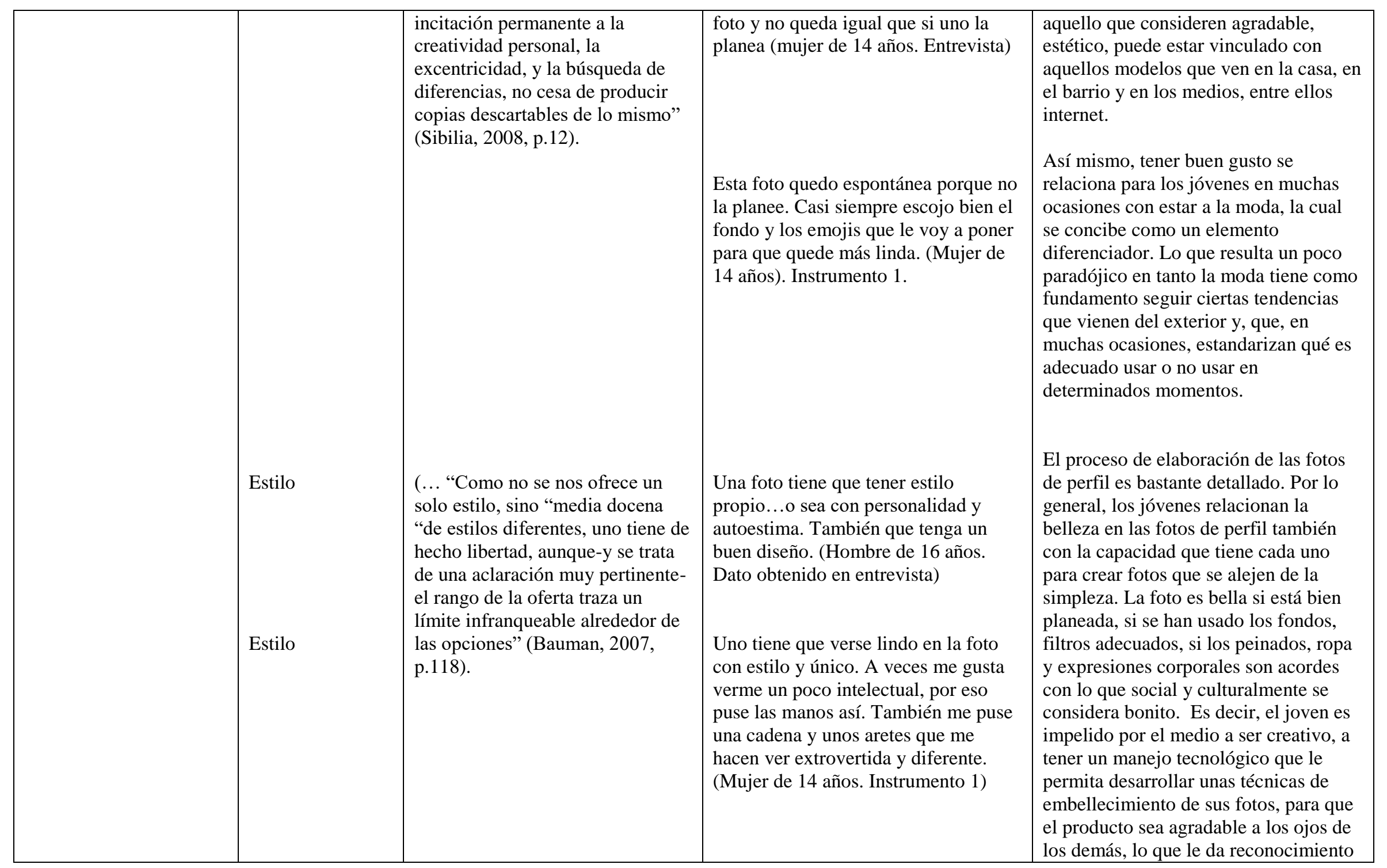


Creo que una foto de perfil es estética cuando uno ha pensado muy bien en qué fondos le va a poner. Ahí toca saber cómo cuadrarla porque si no uno se la tira jjajajjana. La puede dejar peor de lo que estaba. En internet hay resto de aplicaciones, yo la que más uso es la de G612 porque me deja ponerle mi estilo, cambiar la iluminación, me puedo poner aretes ...lo que quiera y siempre les gustan mucho mis fotos a mis amigos por eso. (Mujer de 16 años. Datos obtenidos en entrevista) social. Aquí se vuelve a la reflexión acerca de cómo la foto de perfil se va convirtiendo un objeto-mercancía en muchas ocasiones. No en todas, dado que existen jóvenes cuyos ideales estéticos también se alejan de los normalizados, pero no en la mayoría de los casos.

El estilo se suele conectar en los jóvenes con la capacidad de diseñar fotos de perfil que contengan sus propios gustos, que estén a la moda y que contengan algunos elementos considerados socialmente como personales o propios.

El estilo se convierte para los jóvenes en una búsqueda de identificación personal. De ahí que se conecte

directamente con la tendencia a verse diferente, a desmarcarse de sus pares.

Lo paradójico, es que se suele conectar el tener un estilo propio, con la capacidad para usar prendas de moda o de marcas reconocidas. Por supuesto, algunos jóvenes relacionan el estilo con mostrar sus gustos y preferencias, no necesariamente incluyendo elementos estéticos; sin embargo, nos estamos refiriendo a la predilección de la mayoría de los jóvenes de la muestra. 


\subsection{Resultados sondeo exploratorio}

La primera actividad que se realizó fue el sondeo exploratorio. Para hacerlo, se inició con el video que permitió introducir la pregunta acerca de qué entendían los jóvenes por estética en conexión con el contexto de Facebook y las fotos de perfil, lo que se hizo a partir de un brainstorm, como se describe en la metodología. El principal resultado de esta lluvia de ideas fue que, la mayoría de jóvenes relaciona a la estética con lo bonito o la belleza que se muestra en sus perfiles. La mayoría de palabras que emergieron fueron: bonito, bello, verse bien y expresión personal. Llama la atención en este punto, que algunos jóvenes se remitieron a lo estético, como aquello que expresa un sentimiento o identificación subjetiva y no solo a la apariencia física.

Después de esta lluvia de ideas, se prosiguió a aplicar al grupo un formato con cinco preguntas que fueron las siguientes: 1) ¿Qué entiendes por estética, en relación con las fotos de perfil que publicas en Facebook?; ¿Crees que tus fotos de perfil deben ser estéticas si/no y por qué? Para aproximarnos a la comprensión del concepto central de estética que tienen los jóvenes de una manera más detallada y así facilitar la comprensión acerca de cuáles son sus representaciones sociales sobre dicho concepto. 2) ¿Qué aspectos estéticos o no estéticos tienes en cuenta cuando eliges una foto de perfil para tu cuenta en Facebook? Para ir identificando los elementos que componen las representaciones sociales de la estética de los jóvenes. 3) ¿Qué tipo de ropa, accesorios y posturas corporales utilizas en tus fotos de perfil? Explica tu respuesta. Si no utilizas ninguno de los anteriores elementos o sólo algunos, menciónalo. Para indagar por los conceptos centrales de la pregunta de investigación. 4. ¿Cómo ha sido tu experiencia 
personal con las fotos de perfil en Facebook, en relación con la ropa, accesorios y posturas que utilices en ellas? Si no utilizas ninguno de los anteriores elementos o solo algunos, menciona cuáles usas. Con el fin de identificar las narrativas que expresan los jóvenes acerca de la estética y la foto de perfil y facilitar así la comprensión de sus representaciones sociales. 5) ¿De qué fuentes consideras que has aprendido el tipo de ropa, accesorios, posturas corporales, gestos (si los usas) que muestras en tus fotos de perfil en Facebook? ¿Por qué? Para indagar acerca de los factores contextuales y socioculturales que se relacionan con las representaciones sociales de los jóvenes.

Este sondeo exploratorio se conectó con las cuatro preguntas orientadoras que se plantearon antes, porque apunta a encontrar los elementos que constituyen a las representaciones sociales, para poder identificarlas (pregunta exploratoria 1), además buscó que los jóvenes proveyeran características que facilitaran la descripción de sus representaciones sociales (pregunta exploratoria 2), así mismo permitió encontrar algunos datos acerca de los factores socioculturales que se vinculan con tales representaciones. De ahí que el sondeo contribuya a los dos primeros objetivos específicos, porque se pudieron identificar algunos elementos constitutivos de las representaciones sociales que nos ocupan (objetivo 1), adicionalmente se obtuvieron datos que coadyuvaron para poder describirlas (objetivo 2).

Para analizar los resultados de este sondeo exploratorio, se subrayaron los conceptos más utilizados por los jóvenes, se identificó cuáles se repetían con más frecuencia y se aproximaron semánticamente a términos que puedan contener la mayoría de palabras mayormente mencionadas por los jóvenes. 
Los principales resultados obtenidos por cada pregunta planteada fueron:

Tabla 3 - Preguntas y respuestas sondeo exploratorio

\begin{abstract}
1) ¿Qué entiendes por estética, en relación con las fotos de perfil que publicas en Facebook?; ¿Crees que tus fotos de perfil deben ser estéticas si/no y por qué?
\end{abstract} tienes en cuenta cuando eliges una foto de perfil para tu cuenta en Facebook?
2) ¿Qué aspectos estéticos o no estéticos
3) ¿Qué tipo de ropa, accesorios y posturas corporales utilizas en tus fotos de perfil? Explica tu respuesta.
La mayoría de los jóvenes conecta a la estética con lo bello, lo bonito, la forma de expresarse personalmente, algunas veces con sentimientos $\mathrm{y}$ emociones $\mathrm{y}$ con aquello que los hace sentir identificados en sus fotos de perfil.

La mayoría de los jóvenes respondió que prefieren que su foto de perfil sea bella. Lo será, sobre todo si la ropa, filtros, fondos y accesorios tanto virtuales como no virtuales sea acorde con sus gustos y estilo personal, sobre todo con el fin de gustar a sí mismos y a los demás. No obstante, algunos de ellos mencionaban que lo estético estaría en que fueran fotos representativas y significativas para ellos.

La mayoría de jóvenes contestó que usaban ropa que consideren bonita, accesorios (pero no demasiado recargados) y ropa a la moda o que refleje su estilo propio. Los hombres gustan de usar gorras y gafas. Usualmente hacen algunos gestos que los hagan ver serios y a veces graciosos. Las mujeres gustan de usar ropa que consideren bonita, en ocasiones nueva y preferiblemente a la moda. Usan variedad de accesorios como: aretes, anillos, entre otros. Buena parte de ellas usa maquillaje y algunas posturas corporales que las hacen ver tiernas, lindas y a veces graciosas, pero en menor proporción que en el caso de los hombres. Algunos jóvenes de ambos sexos, sin embargo, afirman que no necesitan usar muchos accesorios o hacer poses en sus fotos de perfil para que estas sean de su gusto.

4. ¿Cómo ha sido tu experiencia personal con las fotos de perfil en Facebook, en relación con la ropa, accesorios y posturas
Buena parte de los jóvenes mencionó que les gusta mostrarse así mismos cuando han estado felices o con sonrisas y posturas 


\begin{tabular}{|l|l|}
\hline que utilices en ellas? & $\begin{array}{l}\text { corporales que los hagan ver felices. Otros } \\
\text { comentaron que les parece importante } \\
\text { tomar fotos de perfil en donde aparezcan } \\
\text { imágenes de recuerdos significativos para } \\
\text { ellos. Otros, escribieron que su experiencia } \\
\text { tiene que ver con el querer verse bien y } \\
\text { llamativos para los demás, en especial sus } \\
\text { amigos. Algunos crean narrativas acerca de } \\
\text { cómo ha sido su interacción con sus pares a } \\
\text { raíz de sus fotos, por ejemplo, si les dan } \\
\text { likes o les aconsejan cómo presentarse en } \\
\text { este espacio virtual. Algunos de los } \\
\text { jóvenes mencionaron como significativo } \\
\text { que han buscado manejar un estilo propio, } \\
\text { sin necesidad de preocuparse por la } \\
\text { opinión de los demás, lo que contrasta con } \\
\text { otra parte de ellos, a quienes síles afectaría } \\
\text { este punto. }\end{array}$ \\
\hline $\begin{array}{l}\text { ¿De qué fuentes consideras que has } \\
\text { aprendido el tipo de ropa, accesorios, } \\
\text { posturas corporales, gestos (si los usas) que } \\
\text { muestras en tus fotos de perfil en } \\
\text { Facebook? ¿Por qué? }\end{array}$ & $\begin{array}{l}\text { La mayoría de fuentes señaladas por los } \\
\text { jóvenes provienen de los medios e } \\
\text { industrias culturales tales como: Internet, } \\
\text { publicidad, televisión, revistas, bandas } \\
\text { musicales. Otra fuente importante es de la } \\
\text { familia. También aprenden cómo mostrarse } \\
\text { en sus fotos de sus amigos y, en algunos } \\
\text { casos, de personas conocidas. }\end{array}$ \\
\hline
\end{tabular}

Con relación a las respuestas dadas por los jóvenes a las preguntas anteriores $\left({ }^{14}\right)$, se pueden analizar algunos aspectos. El primero de ellos, es la belleza. Para la mayoría de jóvenes, lo estético sería aquello que es agradable ante los sentidos, en el caso de Facebook: la vista. Las fotos serán estéticas en tanto sean bonitas, y, para ello deben cumplir con unos requisitos. La mayoría de ellos apunta a que sean bien elaboradas, que cuenten con fondos y filtros que las embellezcan. Muchos señalaban cómo sonreír les ayudaba a verse más bellos, aun cuando solo fuera una sonrisa para la foto. De cualquier manera, otros jóvenes, aunque no la mayoría, relacionaban a la estética con la posibilidad

${ }^{14}$ Las respuestas a todas las preguntas anteriores se pueden encontrar en el anexo A. 
de expresar sus sentimientos y emociones personales. La foto de perfil serviría entonces para mostrar quién se es y qué les gusta, con indiferencia de que esto pudiera ser del agrado de los demás. Lo que es interesante en tanto se empieza a notar cómo entre la mayoría de jóvenes que relacionan a lo estético con mostrarse bello en las fotos, existen algunos que relacionan este concepto con aquello que les satisface a sí mismos a nivel personal.

Frente a las respuestas dadas frente a la pregunta número dos, muchos jóvenes afirmaban que les parecía importante que su foto de perfil reflejara sus gustos $\left({ }^{15}\right)$ personales, frecuentemente con el objetivo de resaltar o diferenciarse del resto. Para muchos de ellos, es fundamental llamar la atención, sobre todo de sus pares, para lo cual elaboran fotos de perfil que puedan ser muy visibles $\left({ }^{16}\right)$, de modo que no pasen desapercibidas. El joven juega con su propia imagen (Bonacci,2013), de modo que pueda presentarse a sí mismo de acuerdo a unas concepciones sobre lo bello que, usualmente, se encuentran atravesadas por el contexto cultural del que hace parte. Claro está, que para algunos de ellos sus fotos de perfil no necesariamente han de ser bellas. Deben, eso sí ser, de su gusto, pero no necesariamente bajo la concepción de belleza que maneja la mayoría. Así, dice uno de los jóvenes: "Pues a veces creo que deben ser bellas y a veces no. Pues desde que me guste a mí, puede estar bien tenga o no tenga filtros" (joven de 15 años. Sondeo exploratorio). No siempre la concepción de lo estético se manifiesta en los jóvenes de la misma manera. Algunos de ellos lo conciben como la expresión de sí mismos a través de sus fotos.

\footnotetext{
${ }^{15}$ Ver ampliación de la subcategoría de gusto en tabla 2.

${ }^{16}$ Ver ampliación de la subcategoría de visibilidad en la tabla 2.
} 
Por otro lado, para la mayoría de los jóvenes es importante que los demás los vean felices. Que aquello que compartan en sus perfiles sea considerado socialmente como agradable. Por ejemplo: algunos jóvenes señalan que les gusta mostrar fotos en donde han viajado o están en buenas condiciones, por ejemplo, a partir de ropa bonita, en ocasiones nueva: "Debo verme bien, que me guste a mí. La ropa debe estar limpia, estar bien peinada y cosas por el estilo” (mujer de 15 años. Pregunta 2).

Otro de los aspectos que señalaban varios jóvenes con relación a la segunda pregunta era que les gustaba estar a la moda, sobre todo en la ropa: "para mí una foto de perfil debe tener un buen gesto, buena ropa, lo que yo considero es eso”. Los accesorios que yo creo es estar a la moda (mujer de 14 años). La moda tiende a conectarse con el buen gusto, con esas elecciones que hace un joven para diferenciarse del resto y así ganar visibilidad $\left({ }^{17}\right)$. Ahora, esas elecciones se conectan no solo con el gusto personal de los jóvenes, sino con los elementos culturales y entorno al que pertenecen Bourdieu (1988). De ahí que sea necesario comprender las motivaciones y modelos que siguen, para acercarse a los sentidos de sus representaciones sociales $\left({ }^{18}\right)$.

Otro aspecto que señalaban los jóvenes en la pregunta 2, era que las fotos de perfil debían llamar la atención para que estas gustaran a los demás y, así obtener aceptación social. Es decir, si los otros aprueban las fotos, el joven se siente más reconocido: "Las fotos que yo publique deben ser bellas, ya que es para que la gente tenga un punto de vista bueno de uno y para que a las personas les gusten y llamen la atención"(joven de 14 años). Obtener la aceptación social por parte de los otros es entonces un aspecto

\footnotetext{
${ }^{17}$ La categoría de visibilidad se amplía en la tabla 2.

${ }^{18}$ Este aspecto se trabajó en la pregunta número 5 del sondeo exploratorio.
} 
importante que varios jóvenes conectan con lo estético en sus fotos de perfil. Ser populares $\left({ }^{19}\right)$ se convierte en un ideal entre varios de ellos, por lo que buscan constantemente indicios de que esto ocurre, por ejemplo en los likes o comentarios que dejan los demás (Morduchowicz, 2012). No obstante, algunos de los jóvenes de la muestra tienen opiniones deferentes al respecto: "No me importa mucho si a otros les gustan o no mis fotos, pero aun así es agradable saber que a las personas les gusta como eres" (hombre de 15 años). Evidentemente, a algunos jóvenes este aspecto parece preocuparles más que a otros, pero en general es un asunto al que brinda atención la mayoría.

En la pregunta 3 se abordó qué tipo de accesorios, ropa y posturas corporales mostraban los jóvenes usualmente en sus fotos de perfil y se les instaba a explicar la respuesta. Las razones que daban los jóvenes para preferir cierto tipo de ropa, accesorios o posturas corporales $\left({ }^{20}\right)$ tenían que ver, en varios casos, con la tendencia a querer diferenciarse de los demás, de desmarcarse a través de elaborar las fotos, tanto en un nivel técnico, por ejemplo aplicando filtros, emoticones o emojis $\left({ }^{21}\right)$, fondos sacados de la red, como usando ciertos accesorios y ropa que les permitan resaltar: "Me gusta usar gafas porque me hacen ver diferente en las fotos. Las gafas me tapan los ojos y me hacen ver mejor" (mujer de 16 años). Dicha tendencia por diferenciarse ${ }^{(22)}$, convierte al cuerpo y a la foto misma en una creación bien elaborada: "la obligación de ser singular, y de que esa originalidad individual esté a la vista. Con este fin el propio cuerpo se vuelve

\footnotetext{
${ }^{19}$ La categoría de popularidad, se amplía en la tabla 2.

${ }^{20}$ El tipo de ropa, accesorios y posturas corporales que señalaron los jóvenes como los más usados se encuentra resumido en la tabla 3-pregunta 3 del sondeo exploratorio.

${ }^{21}$ Son caras animadas que representan emociones por lo general y que son frecuentemente utilizadas actualmente por los jóvenes en sus fotos.

${ }^{22}$ La categoría de diferenciación se desarrolla más en la tabla 2.
} 
un objeto de diseño" (Sibilia,2008, p.292). Muchos jóvenes recurren a muchas técnicas que les brinda el mercado para personalizar su imagen a gusto propio, pero con las limitadas opciones que les dan las aplicaciones que utilizan. Todo parece apuntar a buscar un ideal de perfección que elimine de alguna manera aquello que no sería deseable mostrar en los perfiles: "uso poses ya que con estas poses muestro el lado de la cara o el cuerpo bueno, donde se ve más bello" (mujer de 15 años. Instrumento 2). Por supuesto, esto no aparece en todos los casos. En este sondeo hubo posiciones de jóvenes que valoraban el mostrarse como son, sin usar tantos filtros o elementos embellecedores: "Pues además de mis gorras, no me gusta usar nada más porque yo pienso que uno sin ningún accesorio es bello y además no se necesita algo para ser bello, si uno se considera más bello"(hombre de 14 años)". Lo que nos permite afirmar que, por lo menos en este sondeo, aunque la mayoría de jóvenes valoran a la creatividad para elaborar fotos de perfil que les permitan verse más atractivos y ser así reconocidos, no todos se adscriben a este punto de vista.

En la pregunta número 4, varios de los jóvenes describieron cómo ha sido su experiencia personal frente a la foto de perfil en Facebook. De allí surgieron algunas narrativas que describen cómo en este espacio algunos jóvenes tienden a incluir a sus amigos o lo utilizan en ocasiones para mostrar recuerdos significativos para ellos, como por ejemplo días felices, paseos, entre otros momentos considerados como agradables desde el contexto cultural al que pertenecen los jóvenes. De hecho, ninguno de ellos documentó que en este espacio hubiera publicado una foto en un mal día o en una situación de enfermedad, por ejemplo. Lo que lleva a pensar que es más bien usual que se tenga la idea de que, en este espacio, es conveniente mostrar que se está bien o que se 
posee bienestar: "Me gusta publicar fotos de perfil que tengan recuerdos de regalos y ocasiones especiales" (mujer de 15 años). Para los jóvenes, por lo menos para muchos de ellos, es común mostrar a los demás momentos en donde se pasa por un buen momento Dillon (2013). Aunque, para algunos de ellos, más bien se trate de compartir momentos que les son significativos o recuerdos especiales sin la necesaria carga de bienestar.

Por último, en la pregunta 5, así como en las demás, se pudieron identificar algunos aspectos socioculturales que intervienen en la configuración de las representaciones sociales de los jóvenes acerca de la estética. Entre ellos se destaca el que, la gran mayoría de ellos, obtienen los modelos estéticos a seguir a partir de fuentes mediáticas tales como: Internet y la televisión, siendo el primero el más mencionado. Varios señalan cómo el mismo Facebook les provee ideas acerca de cómo pueden lucir mejor y llamar la atención de los otros: "A veces saco las ideas de YouTube, de los comerciales. Los veo y digo me voy a tomar una foto con esa ropa, viendo perfiles de Facebook" (Hombre de 14 años). Otros señalan a industrias culturales tales como el cine, como modelos para elaborar sus fotos de perfil: "veo tutoriales en los cuales hay chicas que se arreglan bien. Hay imágenes de vestuarios muy llamativos. También en las películas hay chicas que se visten fuera de lo usual y cotidiano. También de mi familia tomo ideas porque se visten elegante, pero a la vez sport” (mujer 15 años, sondeo exploratorio) La familia también suele tomarse como un referente importante, sobre todo los parientes cercanos al joven: "yo aprendi de mi prima a arreglarme para las fotos de perfil, porque ella se combina la ropa muy linda. Me gusta sentirme femenina en mis fotos de perfil" (mujer, sondeo exploratorio). La feminidad aparece también en algunas de las respuestas de las 
jóvenes como un elemento positivo, probablemente aprendido de su contexto cultural y que se asocia con lucir bien, aunque no lo señalan más que dos de las participantes. Por supuesto, también se encontraron respuestas de jóvenes que afirman no seguir modelos culturales para diseñar sus fotos de perfil, apelando a que tienen un estilo personal único.

\subsection{Resultados obtenidos con cuadro de elementos significativos}

Para analizar el instrumento 2 (cuadro de elementos significativos) nos apoyamos en un primer momento en la herramienta cuantitativa del programa de Microsoft Excel®, que sirvió para hallar los porcentajes en que cada joven mencionaba ciertas palabras que se conectan con algunas de las categorías propuestas en la tabla 2. En esta parte, no se tuvo en cuenta la cantidad de veces en que se repetía cada palabra por joven, sino la cantidad de jóvenes que la mencionaron, por lo menos una vez.

Esta herramienta permitió reforzar los datos relacionados con las categorías de análisis que se habían venido trabajando, además de proporcionar otros elementos constitutivos de las representaciones de los jóvenes, útiles en la identificación (objetivo uno) y descripción de las mismas (objetivo 2)

Antes de iniciar este apartado, se aclara que se apeló a lo cuantitativo con el propósito de aportar a la exploración de las tres preguntas orientadoras que se plantearon desde el comienzo. La primera relacionada con identificar las representaciones sociales de los jóvenes acerca de la estética, para lo cual es importante encontrar los elementos que las componen y los sentidos que los jóvenes les dan, lo que se corresponde además con el objetivo número uno de investigación. En segundo lugar, esta parte aporta a la 
pregunta exploratoria dos, porque permite hallar características de los elementos que constituyen a esas representaciones, lo que es fundamental si se pretende describir dichas representaciones (objetivo dos del proyecto). En tercer lugar, aporta al abordaje de la tercera pregunta exploratoria 3, porque le apunta a encontrar las connotaciones culturales que tienen los elementos que componen a las representaciones, por ejemplo, particularidades de género y significaciones dadas a ciertos conceptos relacionados con la ropa, accesorios y posturas corporales que los jóvenes muestran en sus fotos de perfil en Facebook. Información relevante para, posteriormente, realizar un análisis más detallado de esas representaciones, en relación con los elementos culturales y sentidos que les dan los jóvenes (objetivo 3 de investigación), lo que nos lleva, finalmente, a encontrar los sentidos de esas representaciones sociales, razón de ser de esta investigación.

Después de aplicar el instrumento número dos ${ }^{(23)}$ y revisar las expresiones que registraron los jóvenes, se obtuvieron las siguientes frases que fueron mencionadas por la mayoría. Acto seguido, se convirtió cada frase en un concepto así:

Verse lindo (a)-lindura

Verse diferente-diferenciarse

Estar a la moda-moda

Verse tierno- ternura
Verse sonriente-sonrisa

Ser visible o resaltar-visibilidad

Estar serio-seriedad

\footnotetext{
${ }^{23} \mathrm{El}$ instrumento dos sería el cuadro de elementos significativos y se encuentra en el anexo E.
} 
Estos conceptos permitieron conocer los contenidos de las representaciones sociales de los jóvenes, por lo menos desde sus elementos periféricos. Para analizar los datos obtenidos con el instrumento dos, se hallaron los porcentajes en que cada uno de los 30 jóvenes mencionó o se refirió a cada categoría. Los resultados de los porcentajes se realizaron en un cuadro, porque esto facilita la organización de la información. Además, permite que se puedan comparar los porcentajes que se obtuvieron. Cabe anotar que, aunque esta investigación es preponderantemente cualitativa, esta herramienta fue útil porque ofrece la posibilidad de analizar los datos de una manera sencilla y facilitando su análisis cualitativo posteriormente. 
Tabla 4 - Conceptos más mencionados y porcentajes (hombres y mujeres)

\begin{tabular}{|c|c|c|c|c|c|c|c|c|c|c|}
\hline Joven \# & & Lindura & Sonrisa & Diferenciación & Visibilidad & Moda & Ternura & Seriedad & Hombre & Mujer \\
\hline & 1 & $*$ & * & 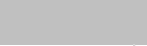 & * & & & & & * \\
\hline & 2 & * & * & 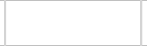 & * & * & $*$ & & & * \\
\hline & 3 & $*$ & * & : & * & & & & & 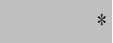 \\
\hline & 4 & 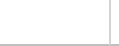 & * & $*$ & * & * & $*$ & * & & * \\
\hline & 5 & $*$ & * & * & * & * & & & & * \\
\hline & 6 & * & * & * & * & | & 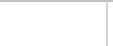 & & & * \\
\hline & 7 & $*$ & * & * & * & $*$ & & & & * \\
\hline & 8 & 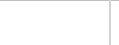 & * & 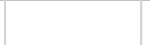 & . & * & & * & & * \\
\hline & 9 & $*$ & * & . & * & & & & & * \\
\hline & 10 & * & * & * & * & * & $*$ & & & * \\
\hline & 11 & $*$ & * & $*$ & * & & & & & * \\
\hline & 12 & * & * & t. & * & 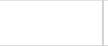 & $*$ & * & & * \\
\hline & 13 & $*$ & . & & & & & & & * \\
\hline & 14 & $*$ & * & 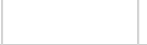 & * & & 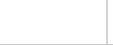 & 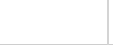 & & * \\
\hline & 15 & - & * & * & & & $*$ & & & * \\
\hline & 16 & $*$ & * & 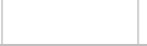 & 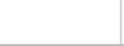 & * & & * & * & \\
\hline & 17 & $*$ & * & & & & & & * & \\
\hline & 18 & & * & t & 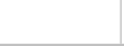 & & & & * & \\
\hline & 19 & * & 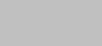 & * & * & * & & * & * & \\
\hline & 20 & $*$ & * & * & 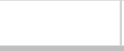 & * & & 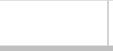 & * & \\
\hline & 21 & & * & & & & & & * & \\
\hline & 22 & * & * & * & 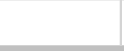 & & & * & * & \\
\hline & 23 & $*$ & . & & * & & & * & * & \\
\hline & 24 & * & 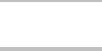 & & . & & & . & * & \\
\hline & 25 & $*$ & * & & & & & * & * & \\
\hline & 26 & & * & & * & & & & * & \\
\hline & 27 & & * & & & & & * & * & \\
\hline & 28 & $*$ & $*$ & & . & & * & & * & \\
\hline & 29 & $*$ & . & $*$ & * & & & * & * & \\
\hline & 30 & * & & * & & & & * & * & \\
\hline Totales & & 23 & 24 & 12 & 16 & 9 & 6 & 11 & 15 & 15 \\
\hline Porcentaje & & $77 \%$ & $80 \%$ & $40 \%$ & $53 \%$ & $30 \%$ & $20 \%$ & $37 \%$ & $50 \%$ & $50 \%$ \\
\hline
\end{tabular}

En esta tabla no se registró la cantidad de veces que un joven mencionara cada categoría, sino que, para efectos del análisis, se tuvo en cuenta únicamente el que se haya referido a cada una por lo menos en una ocasión. 
De acuerdo a los datos que se obtuvieron con el instrumento dos, los jóvenes otorgan mayor relevancia a verse felices en sus fotos de perfil y lo conectan con mostrarse sonrientes. Esta categoría obtuvo el $80 \%$ con relación a las demás. Lo que significa que aparecer mostrando una sonrisa se considera deseable o, por lo menos, relevante.

En el instrumento dos, los jóvenes se referían de hecho a la importancia que daban a aparecer sonriendo en la foto de perfil, aun cuando estuvieran fingiendo, porque aseguraban que les haría verse mejor. Lo que permitió ir identificando una conexión interesante entre verse feliz y verse bien o bello en las fotos.

El segundo concepto que obtuvo mayor porcentaje (77\%) al ser mencionada más recurrentemente fue la de lindura. Los jóvenes escribían en sus cuadros frases como: utilizo este accesorio (virtual o no virtual) para "verme mejor", o "verme más lindo o linda" (esta última sobre todo en por las mujeres), entre otras frases parecidas. Lo que lleva a pensar que para los jóvenes cobra importancia lucir bien en sus perfiles. Ahora, si tenemos en cuenta que esos perfiles son públicos, se puede afirmar que para ellos resulta relevante que otros los reconozcan como bellos.

El tercer concepto que obtuvo un mayor porcentaje fue la de visibilidad con el $53 \%$. En el instrumento uno los jóvenes hacían referencia a la importancia que representaba para ellos el que los demás notaran los cambios que le hacían a sus perfiles, la ropa nueva o a la moda que aparecía en sus fotos, el peinado que estaban usando, lo bien que les quedaban algunas prendas de vestir o accesorios o la forma en que cierto filtro o fondo utilizado mejoraba las fotos.

Lo anterior nos indica que los jóvenes dan relevancia a resaltar frente a los demás. Para hacerlo, algunos de ellos escribían que utilizaban algunas técnicas corporales que 
acentuaban las cualidades físicas que, socialmente, se consideran bellas. Por ejemplo, algunas jóvenes mencionaban que era imprescindible mostrar un cuerpo que luciera bonito, escondiendo lo mejor posible las imperfecciones a través de las poses y filtros utilizados. Editar las fotos es, de hecho, una rutina bastante común en los jóvenes. Aspecto que salió a flote en los cuadros que completaron los participantes.

Lo anterior, lleva a pensar que para los jóvenes es importante que sus fotos de perfil generen un impacto. Que se destaquen. Lo que se conecta con el esmero que invierten en elaborarlas, de modo que sean llamativas, o sea que no pasen desapercibidas. De hecho, en el instrumento uno, algunos jóvenes apuntaban que la intención de realizar ciertas poses, usar algunos accesorios virtuales como los emojis o no virtuales como aretes, gorras, entre otros, era la de resaltar frente a los demás. En ocasiones, incluso agregaban que lo hacían porque querían ganar más likes.

El concepto que siguió en orden descendente en relación con el porcentaje obtenido, fue el de diferenciación con el 40\%. Los jóvenes aducían que para ellos era relevante demostrar a los demás que tenían un estilo propio. Para lograrlo, mencionaban frecuentemente que utilizaban filtros, ropa, accesorios (virtuales y no virtuales), poses, peinados etc., que les permitían dar un toque personal y único a sus fotografías. "verme interesante", "demostrar mi propio estilo" fueron frases recurrentes en las muestras $\left({ }^{24}\right)$. Ese verse distinto parece estar conectado con la habilidad del joven para elaborar una buena foto de perfil, independientemente de lo que ocurra en lo presencial.

El concepto que siguió con el $37 \%$ fue la de seriedad. Para varios de los jóvenes (sobre todo hombres) era importante mostrar fotos en donde se vieran serios. Por

\footnotetext{
${ }^{24}$ Específicamente recurrente en el instrumento dos.
} 
supuesto que mostrar una sonrisa, aunque esta sea una pose solo para la foto, es más común para los participantes de ambos géneros. El verse serio se convierte para varios jóvenes en otra estrategia utilizada para que sus fotos sean valoradas más positivamente por los otros, pues lo conectan en la mayoría de los casos con lucir interesante.

Con el $30 \%$ se encuentra situado el concepto de moda. Si nos fijamos, es un porcentaje relativamente bajo en relación con los que le anteceden. Sin embargo, aparece en las construcciones verbales de los jóvenes.

Usualmente los participantes se referían a la moda para explicar por qué utilizaban ciertos accesorios virtuales o no, ropa, por lo general cuando esta era nueva, o, para aclarar por qué mostraban alguna pose. En algunas ocasiones señalaban que cierto artículo era de una marca específica.

Un joven por ejemplo escribió: "Me tomé la foto de cuerpo completo para mostrar las Nike" 8 (hombre de 14 años, instrumento 2). También en algunos casos dan importancia a las marcas de los celulares con que toman las fotos. Y, como algunas de las fotografías de perfil son tomadas frente al espejo de un lugar cerrado (usualmente el cuarto del joven) o frente a un espejo (frecuentemente en el baño), algunos afirmaban que querían que se notara el modelo del celular que habían usado. Aunque esto fue referido solo por el $30 \%$ de los jóvenes, lo que indica que no es demasiado usual que ellos se refieran de forma directa a la moda o marcas como elementos que tienen en cuenta en sus fotos de perfil, salvo en algunas ocasiones.

Con el 20\% apareció el concepto de ternura (en instrumento dos). Cabe aclarar que, como se verá más adelante, esta palabra o relacionadas se usó más en mujeres; sin embargo, no fue exclusiva en estas. Usualmente el joven que empleaba ese concepto 
explicaba que lo hacía, no porque en verdad fuera o se sintiera tierno en ese momento, sino para parecer tierno en cierta situación.

Observemos los porcentajes que en cada categoría mencionaron las mujeres:

Tabla 5 - Conceptos más mencionados y porcentajes en mujeres

\begin{tabular}{|c|c|c|c|c|c|c|c|c|}
\hline Joven \# & Lindura & Sonrisa & Diferenciación & Visibilidad & Moda & Ternura & Seriedad & Mujer \\
\hline 1 & * & $*$ & & $*$ & & & & $*$ \\
\hline 2 & $*$ & $*$ & & $*$ & $*$ & $*$ & & $*$ \\
\hline 3 & * & $*$ & & $*$ & & & & $*$ \\
\hline 4 & & * & * & $*$ & $*$ & $*$ & * & $*$ \\
\hline 5 & $*$ & $*$ & $*$ & $*$ & $*$ & & & $*$ \\
\hline 6 & $*$ & $*$ & $*$ & $*$ & & & & $*$ \\
\hline 7 & $*$ & $*$ & $*$ & $*$ & $*$ & & & $*$ \\
\hline 8 & & $*$ & & & $*$ & & $*$ & $*$ \\
\hline 9 & & * & & $*$ & & & & $*$ \\
\hline 10 & $*$ & $*$ & $*$ & $*$ & $*$ & $*$ & & $*$ \\
\hline 11 & $*$ & $*$ & $*$ & $*$ & & & & $*$ \\
\hline 12 & $*$ & * & & $*$ & & $*$ & * & $*$ \\
\hline 13 & $*$ & & & & & & & $*$ \\
\hline 14 & $*$ & $*$ & & $*$ & & & & $*$ \\
\hline 15 & & $*$ & $*$ & & & $*$ & & $*$ \\
\hline & & & & & & & & \\
\hline & & & & & & & & \\
\hline & & & & & & & & \\
\hline Totales & 11 & 14 & 7 & 12 & 6 & 5 & 3 & 15 \\
\hline Porcentajes & $73,30 \%$ & $93,30 \%$ & $46,70 \%$ & $80,00 \%$ & $40,00 \%$ & $33,30 \%$ & $20,00 \%$ & $100,00 \%$ \\
\hline
\end{tabular}

En esta tabla observamos cómo para las mujeres aparecer con una sonrisa en sus fotos de perfil es bastante relevante. El 93\% de ellas mencionó la palabra sonrisa para referirse a la pose más importante en sus fotos de perfil. Para el $80 \%$ de ellas es muy importante ser visibles; es decir resaltar ante los demás. En el instrumento uno, las jóvenes señalaban que las poses, ropa y accesorios (virtuales o no) que incluían en sus fotos en el proceso de edición, se usaban para llamar la atención sobre algunas partes de su cuerpo o que la foto gustara más a los otros. 
El concepto de lindura, que se conecta con las frases usualmente utilizadas por las jóvenes como: "verse bien", "verse linda" es el tercero más mencionado. Por su parte, los conceptos que siguen tuvieron los siguientes porcentajes: diferenciación: 46,7\%, moda $40 \%$, ternura $33,3 \%$, seriedad $20 \%$. Al comparar los porcentajes que en las mismas categorías mencionaron los hombres, tendremos un contraste interesante. Observemos ahora los mismos porcentajes, pero en el caso de los hombres.

Tabla 6 - Conceptos más mencionados y porcentajes en hombres

\begin{tabular}{|c|c|c|c|c|c|c|c|c|}
\hline Joven \# & Lindura & Sonrisa & Diferenciación & Visibilidad & Moda & Ternura & Seriedad & Hombre \\
\hline 16 & $*$ & $*$ & & & $*$ & & $*$ & $*$ \\
\hline 17 & $*$ & * & & & & & & $*$ \\
\hline 18 & & $*$ & & & & & & $*$ \\
\hline 9 & $*$ & & $*$ & $*$ & $*$ & & $*$ & $*$ \\
\hline 20 & $*$ & $*$ & $*$ & & $*$ & & & $*$ \\
\hline 21 & & $*$ & & & & & & $*$ \\
\hline 22 & $*$ & $*$ & $*$ & & & & $*$ & $*$ \\
\hline 23 & $*$ & & & $*$ & & & $*$ & * \\
\hline 24 & $*$ & & & & & & & $*$ \\
\hline 25 & $*$ & $*$ & & & & & $*$ & $*$ \\
\hline 26 & & $*$ & & $*$ & & & & $*$ \\
\hline 27 & & $*$ & & & & & * & * \\
\hline 28 & $*$ & $*$ & & & & $*$ & & $*$ \\
\hline 29 & $*$ & & $*$ & $*$ & & & $*$ & $*$ \\
\hline 30 & $*$ & & $*$ & & & $*$ & & $*$ \\
\hline & & & & & & & & \\
\hline Totales & 11 & 10 & 5 & 4 & 3 & 2 & 7 & 15 \\
\hline Porcentajes & $73,30 \%$ & $66,70 \%$ & $33,30 \%$ & $26,70 \%$ & $20,00 \%$ & $13,30 \%$ & $46,70 \%$ & $100,00 \%$ \\
\hline
\end{tabular}

El porcentaje más alto en los conceptos mencionados con más frecuencia fue el de lindura con el $73 \%$, mientras que en caso de las mujeres el más alto fue el de la sonrisa $(93,3 \%)$. La diferencia es significativa porque mientras que las jóvenes prefieren que se les vea sonriendo en las fotos, los hombres optan por salir guapos o atractivos, pero no 
necesariamente conectan esto con verse sonrientes, por lo menos no en el mismo nivel que las chicas. Este aspecto nos va dando luces para comprender no solo los elementos que constituyen las representaciones sociales, sino las diferencias que existen dentro de las mismas para cada género. De todas maneras, para ambos géneros mostrar la sonrisa es importante, aunque lo sea más para las mujeres. En el caso de los hombres, este concepto tuvo el $66,7 \%$. El tercer concepto con mayor porcentaje para los chicos fue la de seriedad, con el 46,7\%. Si comparamos este resultado con el de las chicas, observamos cómo aparecer serias en las fotos, es menos frecuente para ellas cuando se trata de salir bellas en las fotos. El porcentaje obtenido en seriedad fue del $20 \%$ para ellas, es decir menos de la mitad que en los hombres. Lo que indica que existe una tendencia mayor en los hombres a querer verse serios en las fotos, lo que conectan con verse más guapos, de acuerdo a las ideas que expresaban en los cuadros de elementos significativos.

Los conceptos que siguen obtuvieron los siguientes porcentajes en los hombres: diferenciación: 33,3\%, visibilidad 26,7\%, moda 20\%, ternura 13, 3\%. Al realizar la comparación con los obtenidos en el caso de las mujeres en los mismos conceptos: diferenciación 46,7\%, visibilidad $80 \%$, moda 40\%, ternura 33,3\%, observamos diferencias significativas. De acuerdo con estos datos, las mujeres otorgarían mayor importancia a que sus fotos de perfil incluyan elementos personalizados, para lo cual se valen no solamente de ropa, poses, sino de la gran gama de fondos, accesorios y maquillaje virtual y no virtual que encuentran a su disposición en la red. Por supuesto que los hombres también utilizan recursos similares, pero en menor proporción que en caso de las chicas participantes. 
El concepto cuya diferencia entre los géneros fue más grande fue sin duda la de visibilidad. Mientras que en las mujeres esta obtuvo el $80 \%$, en los hombres únicamente el 26,7\%. Lo anterior pudo constatarse en las expresiones de las jóvenes, quienes constantemente hacían alusiones a que incluían ciertas poses, accesorios y ropa, con el fin de llamar la atención. Para ellas, en su gran mayoría, el proceso de edición de sus fotos de perfil está orientado a resaltar. Para lograrlo, utilizan no solamente los recursos materiales que tienen a la mano, sino que se tienden a usar programas y aplicaciones como: Snapchat, B612, Sweet Selfie, entre otros. Por supuesto los hombres también utilizan las herramientas virtuales para embellecer sus fotos, pero señalan en menor proporción que las mujeres que lo hagan para llamar la atención. Embellecen sus fotos usando sobre todo filtros y fondos, pero según varios de ellos lo hacen para que "la foto quede mejor".

La moda fue otro de los conceptos en donde hubo marcadas diferencias. Mientras para en el caso de los hombres solo el $20 \%$ mencionó este aspecto, en las mujeres el $40 \%$ señaló a la moda como un factor importante para embellecer sus fotos. Las mujeres de hecho solían agregar que les gustaba mostrar la ropa, sobre todo cuando esta era nueva para que resaltara. Los hombres mencionaron la moda en algunos casos, pero sobre todo refiriéndose a marcas específicas de zapatillas o ropa deportiva. De todas maneras, no deja de llamar la atención que esta categoría de moda no sea mencionada en altas proporciones por ninguno de los géneros, en comparación con la de sonrisa, lindura, visibilidad, diferenciación que tuvieron más altos porcentajes.

El último concepto: ternura, tuvo en los hombres solamente un 13,3\%, cifra baja en comparación con el que obtuvo en las mujeres: 33,3 \%. Lo que es llamativo, en la 
medida en que si contrastamos este resultado con el alto porcentaje que tuvo la seriedad en los hombres $(46,7 \%)$, podemos notar que en las mujeres existe una relación entre verse tiernas y belleza, mientras que en los hombres es la seriedad la que podría conectarse con el atractivo que pueden mostrar en sus fotos de perfil.

Todos los conceptos, comparaciones entre porcentajes y lo que estos arrojaron, proporcionaron información fundamental para reconocer el contenido, elementos periféricos y relaciones de las representaciones sociales de los jóvenes, cumpliéndose así el objetivo número uno propuesto en este trabajo.

Cabe aclarar que este estudio no se realizó necesariamente bajo una perspectiva de género, ni se pretende que los resultados obtenidos sean contundentes sobre la perspectiva de género en las representaciones sociales de los jóvenes, pues se reconoce que la muestra no es lo suficientemente grande ni se buscó enfocar este aspecto. No obstante, sí se registraron diferencias en los porcentajes en que hombres y mujeres mencionaban ciertos aspectos. Lo que hace parte de los hallazgos de este trabajo, razón por la que es visibilizado.

\subsection{Resultados obtenidos con mapa semántico}

Este instrumento permitió que los jóvenes señalaran qué elementos centrales y periféricos encuentran en sus fotos de perfil, en relación con la ropa, posturas corporales y accesorios que muestran usualmente en ellas, partiendo de la palabra estética. La idea era indagar por los sentidos y significaciones que les dan a estos elementos, registrándolo 
en un esquema tipo mapa semántico que proveyó la investigadora( $\left.{ }^{25}\right)$ Se trató de encontrar cómo se conectaban esos significados con las concepciones de los participantes acerca de la estética. Lo anterior porque esto nos permitiría conectar esas construcciones simbólicas con el contexto social y cultural (Moscovici.1979; Jodelete,1984) al que pertenecen los jóvenes, aspecto fundamental a la hora de analizar representaciones sociales.

Con este instrumento se apuntó a abordar las tres preguntas exploratorias, porque la información registrada por los jóvenes permitió: a) encontrar algunos elementos constitutivos de las representaciones sociales (pregunta 1), b) con esos elementos se pudo adelantar la descripción de dichas representaciones (pregunta 2) y c) como los jóvenes debía registrar conceptos centrales y secundarios en el mapa, fue posible detectar en qué orden de importancia los organizaban en relación al núcleo, estrategia asociativa adecuada a los postulados de Abric (2001), en donde para estudiar las representaciones sociales, se recomienda que los sujetos de la investigación tengan la posibilidad de asociar conceptos libremente, para que luego el investigador trate de encontrar las cadenas de sentido que van formando las palabras, tal como se hizo para analizar los resultados obtenidos con este instrumento.

Como algunos de los conceptos y sus asociaciones correspondían con aspectos culturales, se pudo trabajar también la pregunta exploratoria tres, que se enfoca en este punto. Así mismo, se abordaron los dos primeros objetivos específicos, debido a que las ideas registradas por los jóvenes y que correspondieron a sus propios significados acerca de esas fotos, permitieron encontrar elementos constitutivos de las representaciones

\footnotetext{
${ }^{25}$ Este instrumento (3) se puede observar en el anexo F.
} 
sociales y realizar un primer borrador de cuáles podrían ser las representaciones sociales (objetivo uno) y cómo podrían estas ser descritas (objetivo dos).

La mayoría de los jóvenes relaciona a la estética con la palabra belleza, con lo bonito y con las estrategias que se conocen y utilizan para elaborar una foto de perfil a partir del uso de fondos, filtros, accesorios virtuales y no virtuales, maquillaje y posturas corporales, entre otros elementos que se usan para embellecer las fotos actualmente. Adicional a ello, se conecta a la belleza con salir bien en las fotos de perfil usando ropa llamativa, en ocasiones de marcas conocidas y, preferiblemente que esté de moda.

Frecuentemente, cercano al núcleo del mapa donde estaba la palabra estética, los jóvenes ubicaron palabras relacionadas con las técnicas que usan para embellecer sus fotos, por ejemplo, las poses, los filtros, los accesorios, las poses. La principal pose que aparece comúnmente cerca a la palabra estética es la de sonrisa. Algunos de ellos dividen esta palabra entre fingida y real, lo cual llamó mucho la atención, pues los jóvenes diferencian entre las fotos de perfil que rememoran un momento realmente significativo para ellos, de otras en donde simplemente quieren a aparecer atractivos.

Otro aspecto que con el que relacionan comúnmente a lo estético, es tener personalidad. Esta palabra aparece frecuentemente cercana al núcleo de los mapas completados por los jóvenes. Dicha palabra la conectan en un orden jerárquico descendente con otros conceptos tales como: tener estilo, verse diferente, resaltar partes 
del cuerpo a través de ropa, maquillaje (mujeres), accesorios, etc. Esos conceptos, usualmente desembocan en querer llamar la atención, ganar likes, ser popular.

En otras ramificaciones del mapa también cercanas al núcleo, algunos jóvenes ubican palabras que se conectan con demostrar emociones, como por ejemplo estar feliz, estar triste (menos veces), lo que reflejan a través de poses. Es más usual que los hombres agreguen palabras que conecten estética con seriedad o verse graciosos en algunas fotos. Las jóvenes utilizaron palabras más conectadas con la sensualidad, como verse sexy. En varias ocasiones las mujeres conectaban estética con poses que las hicieran ver tiernas. Lo común para ambos sexos es que se desea diferenciarse para ser visible para los demás, resaltando a partir del uso elementos que les permitan embellecer sus fotos.

Por supuesto, también se dio el caso de que algunos de los jóvenes de la muestra conectaron a la estética con otro tipo de conceptos que no se correspondían con la generalidad. Por ejemplo, con la integridad, el amor, la seguridad en sí mismos. O en algunos casos ocurrió que en algunas ramificaciones del mapa se agregaban conceptos relacionados con estética vinculados con sus experiencias personales, vivencias, sentimientos, lo que nos lleva a pensar que un solo joven puede tener más de una concepción acerca de lo que es para ellos la estética, específicamente en relación con las fotos de perfil.

\subsection{Resultados obtenidos con entrevista semiestructurada}

La entrevista grupal apuntó a las tres preguntas exploratorias porque a) permitió consolidar cuáles eran las representaciones sociales de la estética, debido a que realizó la comparación entre los resultados obtenidos con los dos primeros instrumentos (pregunta 
1). b) proporcionó más datos que permitieron realizar una descripción más detallada de las representaciones (pregunta 2) y c) porque los resultados obtenidos ampliaron la información con la que ya se contaba sobre las connotaciones culturales implícitas en los significados que los jóvenes dan a los indicadores corporales que muestran en sus fotos de perfil. Por su parte, la entrevista se enlaza con los dos primeros objetivos específicos de esta investigación, porque posibilitó complementar la información con la que ya se contaba para identificar las representaciones sociales de los jóvenes (objetivo 1) y porque proporcionó información más detallada y experiencial sobre las concepciones estéticas de los jóvenes en relación a sus fotos de perfil, lo que permitió describir las representaciones de los mismos.

La entrevista contó con diez preguntas base que se mencionan a continuación:

Tabla 7 - Preguntas entrevista semiestructurada

\begin{tabular}{|c|l|l|}
\hline $\begin{array}{c}\text { Número } \\
\text { de } \\
\text { pregunta }\end{array}$ & \multicolumn{1}{|c|}{ Preguntas } & \multicolumn{1}{|c|}{$\begin{array}{l}\text { Categorías y subcategorías } \\
\text { ospectos centrales a } \\
\text { indagar }\end{array}$} \\
\hline$\# \mathbf{1}$ & $\begin{array}{l}\text { ¿Qué criterios tienes en cuenta para publicar una } \\
\text { foto de perfil en Facebook con relación a la } \\
\text { ropa, accesorios y posturas corporales? }\end{array}$ & $\begin{array}{l}\text { Todas las categorías y } \\
\text { subcategorías mencionadas en } \\
\text { la tabla 2 }\end{array}$ \\
\hline$\# \mathbf{2}$ & $\begin{array}{l}\text { ¿Qué motivaciones tienes para publicar fotos de } \\
\text { perfil con los criterios de la pregunta anterior? }\end{array}$ & $\begin{array}{l}\text { Todas las categorías y } \\
\text { subcategorías mencionadas en } \\
\text { la tabla 2 }\end{array}$ \\
\hline$\# \mathbf{3}$ & $\begin{array}{l}\text { ¿Qué herramientas de la plataforma de } \\
\text { Facebook, específicamente las relacionadas con } \\
\text { la foto de perfil, te permiten saber si tus fotos } \\
\text { han gustado a los demás? }\end{array}$ & $\begin{array}{l}\text { Aspectos contextuales de la } \\
\text { plataforma y su relación con las } \\
\text { fotos de perfil de los jóvenes }\end{array}$ \\
\hline$\# \mathbf{4}$ & $\begin{array}{l}\text { ¿Cómo te afecta a ti la reacción de los demás } \\
\text { frente a tus fotos de perfil? }\end{array}$ & $\begin{array}{l}\text { Categoría de reconocimiento. } \\
\text { Subcategorías: visibilidad, } \\
\text { aceptación social, popularidad }\end{array}$ \\
\hline$\# \mathbf{5}$ & $\begin{array}{l}\text { ¿Qué tipo de ropa, accesorios y posturas } \\
\text { corporales no consideras estéticas para mostrar } \\
\text { en tus fotos de perfil en Facebook? ¿Por qué? }\end{array}$ & $\begin{array}{l}\text { Todas las categorías y } \\
\text { subcategorías mencionadas en } \\
\text { la tabla 2 }\end{array}$ \\
\hline$\# \mathbf{6}$ & $\begin{array}{l}\text { ¿Cómo ha sido tu experiencia personal en en } \\
\text { Facebook en relación a la forma en que } \\
\text { presentas tus fotos de perfil, específicamente a }\end{array}$ & $\begin{array}{l}\text { Narrativas y aspectos } \\
\text { biográficos de los jóvenes en } \\
\text { relación a sus representaciones }\end{array}$ \\
\hline
\end{tabular}




\begin{tabular}{|c|l|l|}
\hline & $\begin{array}{l}\text { partir de la ropa, accesorios y posturas } \\
\text { corporales que muestras en ellas? }\end{array}$ & sociales sobre la estética \\
\hline$\# \mathbf{7}$ & $\begin{array}{l}\text { ¿Tienes un modelo a seguir cuando elaboras una } \\
\text { foto de perfil en Facebook, específicamente en } \\
\text { relación con la ropa, accesorios y posturas } \\
\text { corporales que muestras en ellas? Explica } \\
\text { ampliamente por qué. }\end{array}$ & $\begin{array}{l}\text { Aspectos socioculturales de las } \\
\text { representaciones sociales de los } \\
\text { jóvenes acerca de la estética }\end{array}$ \\
\hline$\# \mathbf{8}$ & $\begin{array}{l}\text { ¿Qué relación tiene la apariencia física que } \\
\text { muestras en tus fotos de perfil en Facebook con } \\
\text { la ropa, accesorios y posturas corporales que } \\
\text { usas en ellas? }\end{array}$ & $\begin{array}{l}\text { Categoría: belleza. } \\
\text { Subategorías: perfección. }\end{array}$ \\
\hline ¿ 9 & $\begin{array}{l}\text { ¿Crees que es importante tener alguna estrategia } \\
\text { para lucir mejor en tus fotos de perfil en } \\
\text { Facebook, específicamente en relación a ropa, } \\
\text { accesorios y posturas corporales? ¿Por qué? }\end{array}$ & $\begin{array}{l}\text { Cubcategorías: diferenciación, } \\
\text { gusto, moda, creatividad, estilo. }\end{array}$ \\
\hline \# 10 & $\begin{array}{l}\text { Si tienes una estrategia para lucir mejor en tus } \\
\text { fotos de perfil ¿Cuál o cuáles son esas } \\
\text { estrategias? ¿Por qué consideras que puede(n) } \\
\text { funcionar? }\end{array}$ & $\begin{array}{l}\text { Categoría: personalización. } \\
\text { Subcategorías: diferenciación, } \\
\text { gusto, moda, creatividad, estilo. }\end{array}$ \\
\hline
\end{tabular}

La mayoría de los jóvenes de la muestra vinculan el concepto de estética en relación a sus fotos de perfil, con lucir bellos o atractivos en las mismas. Aspecto que se reitera en los datos obtenidos con los instrumentos anteriores. Pero en esta ocasión se hizo más clara la relación que hace la mayoría entre estética y expresión personal, con aquello que los identifica y los diferencia de los demás.

La belleza sigue siendo una palabra fundamental para los jóvenes al hablar de la estética. Y, como la como la conectan usualmente con la forma en que aparecen en las fotos, la mayoría afirma que los criterios más importantes para ellos en relación con la ropa, accesorios y posturas corporales es que la foto sea muy bonita. Para ello se valen de diferentes estrategias que se aplican tanto desde lo virtual, como desde lo presencial. En lo virtual, estaría el tratamiento que hacen los jóvenes a sus fotos a partir de aplicaciones como Sweet Selfie, Snapchat, G612, entre otras, y que les permiten adecuar sus fotos de acuerdo a cómo les interesa que salgan. Usualmente se prefieren fotos 
llamativas, en donde su personalidad sea algo que otros puedan ver (Sibilia, 2008). Aquello que no se muestra, que no figura, parece que no tiene las mismas condiciones de existencia actualmente en el contexto de las redes sociales, específicamente Facebook.

Por otra parte, cabe resaltar también la opinión de algunos de los jóvenes de la entrevista, para quienes las fotos no necesariamente debían ser bonitas, no por lo menos en el sentido en que lo son para la mayoría: “bueno, yo creo que lo más importante es que a mí me guste la foto. A veces creo que las fotos deben ser bonitas y a veces no y pueden estar bien, tengan o no tengan filtros, puedo considerar bella siempre que mi sonrisa se vea bien la considero bella” (hombre. Entrevista semiestructurada).

En este caso la relevancia está más en que al mismo joven le guste su foto, pero sí se concede una especial atención al hecho de sonreír en la foto. Aspecto que se repite en los datos recogidos con los tres instrumentos, lo que nos lleva a pensar que verse feliz en las fotos, es considerado por la mayoría como un indicativo de belleza.

Lo bello parece conectarse con lo perfecto. Los cuerpos, los rostros, los peinados deben corresponder con aquello que los jóvenes consideran adecuado, bello y deseable publicar: joven de 15 años: “(...) lentes porque se ven bien, bueno claro que ese no es gesto jajá, de medio lado porque es mejor para solo se vea una parte del cuerpo. Investigadora: ¿Por qué querrías que solo se viera una parte del cuerpo? Joven: pues que se vea la parte buena, la que me gusta mostrar. Existe entonces una selección hecha a conciencia de aquellas fotos, partes del cuerpo que el joven quiere que aparezcan, ocultando o buscando estrategias para que las que no considera apropiadas, no sean vistas por sus posibles espectadores. Las fotos son diseñadas de acuerdo a unos 
imperativos sociales que, frecuentemente, buscan normalizar aquello que se considera agradable, está en forma o es atractivo (Lipovetsky, 2003). La plataforma tiene una estructura que permite al joven pensar que su perfil será diseñado enteramente apelando a sus gusto y estilo personal, el cual lo diferenciará del resto, porque le es propio. No obstante, las opciones que da para personalizar el perfil están bastante bien delimitadas por la arquitectura misma del sitio. Por ejemplo, la misma opción de dar un "like” o escribir un cometario, o los emoticones disponibles o el diseño mismo de la sesión que alberga las fotos de perfil, ya están generando una cantidad de opciones más bien limitadas. Lo anterior es compatible con el concepto de personalización de Lipovetsky (2003), para quien en ese proceso los mercados tratan de hacer creer a los individuos que tienen toda la libertad para elegir, para ser únicos y auténticos, cuando las opciones ya están dadas de antemano y no se modifican fácilmente.

De hecho, en gran parte de las respuestas que daban los jóvenes a preguntas relacionadas con aquellos criterios que tenían en cuenta en sus fotos de perfil, en relación con ropa, accesorios, etc., se mencionaba que lo más importante era poder diferenciarse de los demás, demostrando un estilo propio, pero que debía llamar la atención. La moda es uno de los elementos más referidos por los jóvenes para lograr dicho objetivo: "Casi siempre me gusta estar a la moda y uno aprende a usar la ropa para cualquier ocasión. Para mí una foto de perfil linda es que tenga unos buenos fondos y que uno use una ropa linda y que lo haga sentir a uno cómodo. Queda bien si uno la sabe decorar y la edita bien Ahh... el peinado también es importante, que los demás vean que uno tiene buen gusto" (Mujer de 16 años). La creatividad en la elaboración de esas fotos se considera de hecho para varios de los jóvenes, como una condición importante para que la foto quede 
bonita. No hay mucho espacio para la improvisación, si se quiere obtener el resultado esperado: "creo que mi estrategia es usarfondos lindos, labial, poses que yo crea que se me pueden ver bien, ponerme ropa linda como ombligueras y sacos bonitos como dije antes...creo que es importante pensar bien las fotos, algunas una se las toma un poco desprevenida y no salen igual y creo que puede funcionar (...) (mujer de 16 años). La creatividad va de la mano con el interés por visibilizarse frente a los demás, de ser reconocido y aceptado. Entre más bellas resulten las fotos, más posibilidades tiene el joven de ganar popularidad: "Pues yo uso todos esos fondos, gestos y ropa bonita para que la gente tenga un buen punto de vista de uno porque se ve bien y para que a las personas les guste y les llame la atención” (hombre de 14 años)

Ahora bien, no todos los jóvenes tienen ni la misma concepción sobre lo estético ni los mismos intereses con sus fotos de perfil. Lo mencionado anteriormente aplica para muchos de los jóvenes, no solo los colaboradores en la entrevista, sino para la mayoría de los participantes en esta investigación. No obstante, no se puede desconocer que, dentro de estos resultados generales, hay posturas diferentes. Por ejemplo, en relación con lo que se considera bello en las fotos de perfil: "Yo creo que lo bonito también está en lo que tiene imperfecciones, no todo tiene que salir perfecto o no sería natural” (...) "Para mí la belleza es mirarse y no mirar tanto tus imperfecciones sin importar lo comenten y si les gusta" (mujer de 14 años). En este caso, encontramos no solo una joven que tiene una concepción estética distinta con relación a la perfección que se tiende a asumir como el canon de belleza en las sociedades consumistas (Bauman, 2007) y en donde las imágenes se empiezan a convertir en mercancías consumibles, sino que propende por señalar lo imperfecto como un aspecto estético también. Esta joven no fue 
la única que se distanció de una concepción estética diferente a la de la mayoría De hecho, algunos jóvenes en esta entrevista demostraron tener una concepción estética más conectada con la expresión de sí mismos y de sus experiencias personales significativas.

Otros se mostraron reacios a da demasiada importancia a las opiniones de los demás frente a la forma en que aparecen en sus perfiles: "yo me arreglo y me visto no para que los demás opinen y si me critican no los escucho, porque a mí no me gusta opinar de las otras personas que, si están feos o si están lindos, no me gusta.” (...) “Pues si les gusta bien, pues si no, me resbala, porque yo me peino para mí, me visto para mí, todo lo hago para mí. Me podría muy feliz por ellos me aceptan como soy, yo no le tengo que hacer arreglos a las fotos porque así soy yo". Por supuesto existe un contraste con otros jóvenes para quienes tener un estilo propio, seguir las modas y demostrar que tienen buen gusto sí se justifica por el ansia de ser reconocidos socialmente: "Pues cuando me hacen comentarios buenos sobre mis fotos, a mí me da mucha alegría y sé que me están apoyando detrás de la pantalla” (...) Investigadora: y cuando los comentarios no son tan favorables ¿qué haces? Joven: "Pues los borraría o haría un comentario al respecto. A veces cuando publico una foto y mis amigos no me dan tantos likes o la ignoran la cambio inmediatamente, porque eso quiere decir que la foto no impactó tanto...o sea que no les gustó tanto. Entonces me tomo una mejor” (mujer de 14 años).

Lo anterior no quiere decir que una otra posición sea mejor que la otra. De hecho, se considera que, incluso los jóvenes que dan gran importancia a que su imagen sea impactante y que elaboran sus fotos con sumo cuidado, para que estas resulten impactantes a los demás y lograr así visibilidad, imprimen en ellas aquellas 
particularidades que les caracterizan. Aspecto que se desarrollará más adelante cuando se hable de la relación entre los jóvenes-comunicación y estética, en el capítulo de discusión de resultados y conclusiones.

Con relación a los aspectos socioculturales enlazados con las representaciones sociales de los jóvenes hallados a partir de la entrevista, se puede mencionar que, nuevamente aparece la concepción en algunas de las jóvenes de que su foto de perfil será bella si se asumen poses sensuales, tiernas. Lo que puede tener origen en algunos estereotipos femeninos que se ven por doquier en los medios o que son traspasados de generación en generación a través de la familia. Lo anterior dado que para muchos jóvenes de la muestra los modelos estéticos que les sirven para crear sus fotos de perfil están precisamente en esas fuentes, según lo veíamos en los resultados arrojados por el sondeo exploratorio y en los datos obtenidos con el instrumento dos (cuadro de elementos significativos) y en esta entrevista: "Pues a mí me gusta mirar actrices muy bonitas y me gusta su forma de vestirsen. O miro a los youtubers porque me agrada la forma de versen o miro la página de Internet porque salen muchos consejos de cómo vestirse uno de acuerdo al cuerpo que tenga. También miro a mis actores de las películas que me han gustado, a mis amigos...porque me gusta como se visten, o de la música y ...que más...ummm ah y de revistas profe, que muestran muchos ejemplos de moda” (joven de 14 años)

La televisión, Internet, el cine, las revistas, los amigos y la familia son las fuentes más señaladas por los jóvenes para adoptar los modelos estéticos que luego manifiestan en sus fotos de perfil. Por supuesto, analizar todos y cada uno de los aspectos del acervo cultural que los jóvenes tienen en cuenta en sus perfiles, es un trabajo que excede los límites de esta investigación. Pero sí se señalan las fuentes para tratar de comprender un 
poco más de dónde provienen gran parte de los sentidos que tienen las representaciones sociales de los jóvenes acerca de lo estético.

\subsection{Representaciones sociales de los jóvenes acerca de la estética}

Después de aplicar los instrumentos de investigación con los jóvenes, se realizó el análisis de los datos obtenidos, comparando los proporcionados por los tres instrumentos y se identificaron las representaciones sociales de los jóvenes acerca de la estética, con lo cual se abordó el objetivo específico número uno. Después se describieron esas representaciones, dando cumplimiento al objetivo número dos. A continuación, aparecen dichas representaciones con su correspondiente descripción. Se aclara que estas representaciones son las identificadas en una gran mayoría de los jóvenes de la muestra, mas no en todos los participantes sin excepción. Como se fue registrando y ejemplificando en los resultados obtenidos con cada instrumento, existen jóvenes que tienen concepciones sobre la estética que no se corresponden con los de la mayoría.

\subsubsection{Representación: apariencia de felicidad.}

Uno de los gestos más utilizados a la hora de posar para una foto destinada al perfil, es la sonrisa. Los jóvenes la relacionan con verse atractivos o salir mejor en la foto. A despecho por ejemplo de mostrar otro tipo de actitudes que también hacen parte de lo cotidiano, como momentos tristes o de enfermedad. Por supuesto que existen casos en que no se sonríe para la foto o en que, a propósito, el joven puede asumir un rostro de tristeza para posar, pero de acuerdo a los resultados obtenidos, esto no es lo usual. 
Este es precisamente el núcleo de la representación: mostrar una actitud alegre proyecta felicidad a los demás: "uy...sonreír, que siempre tener una sonrisa, lentes porque se ven bien, bueno claro que ese no es gesto jajja, de medio lado porque es mejor para solo se vea una parte del cuerpo" (sondeo exploratorio). Demostrar a los demás que se tiene un bienestar se conecta con verse feliz y, esto último, con verse bello. Lo anterior aparece en algunas frases utilizadas por los jóvenes en ambos instrumentos como: "quería demostrar que estaba feliz”; "quería parecer feliz" (del instrumento dos).

Nótese cómo los verbos de las frases indican no que se tenga realmente un estado de felicidad; más bien denotan la apariencia de serlo. Esta es una tendencia en prácticamente las cuatro representaciones halladas. Adicionalmente, aparece la importancia de que los demás se enteren de que se está feliz. Solo haciendo partícipes a los demás, tendría sentido para el joven asumir ciertas poses conectadas con alegría y bienestar en sus fotos de perfil.

Observemos algunas de las principales conexiones que se identificaron en los mapas semánticos completados por los jóvenes en relación a la representación que nos ocupa: 


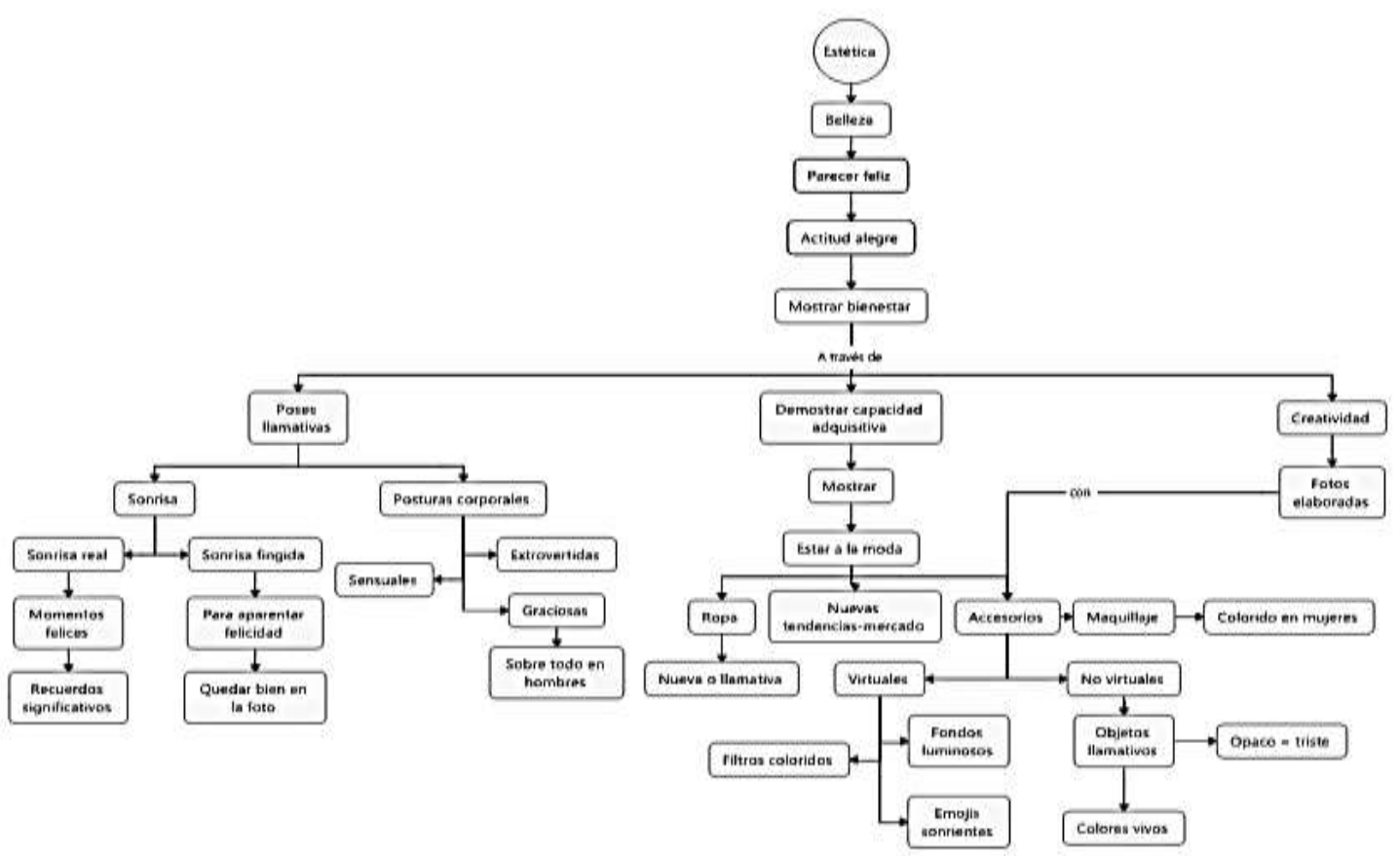

Figura 1

Mapa conceptual organización y jerarquía de la representación social: apariencia de felicidad.

La principal pose que es usada para parecer feliz es definitivamente la sonrisa, aunque puede ir acompañada de otras que incluyen diferentes partes del cuerpo, como la posición de los brazos, entre otros gestos. Los jóvenes reconocen la diferencia entre una sonrisa real y una fingida. La primera, se muestra para documentar momentos realmente felices. Es decir, funciona para compartir con los otros algunos momentos realmente significativos para el joven.

El segundo tipo de sonrisa (fingida) tiene la función específica de embellecer la foto. De hecho, algunos jóvenes señalan que, en ocasiones, aun cuando no tenían deseos de sonreír, lo hacían para verse mejor. He aquí lo que expresa una joven al respecto cuando escribía el significado de su sonrisa en una foto: "Me la tomé de los ojos para abajo 
porque pensé que se vería bien. No sonreí porque no me gustaba, entonces sólo hice un pequeño gesto con la boca y ya" (del instrumento 2).

Otros jóvenes escribieron en el instrumento 2, en la parte en que debían explicar el significado de los elementos significativos para ellos en sus fotos: Sonrisa fingida: "en ese momento no quería sonreír así que fingi una risa”; Sonrisa: para demostrar felicidad. Sobresalen en estas frases verbos como fingir y demostrar. Ambos afines con mostrar a los demás algo, que, en este caso, no es necesariamente cierto.

Otras de las poses llamativas que los jóvenes conectan con la apariencia de felicidad, son gestos o posiciones del cuerpo que los hacen ver extrovertidos, sensuales y, en algunos casos, graciosos (esta última especialmente en hombres. Lo general a estas posturas, es que se muestran para parecer felices, no para documentar que en verdad lo estaban.

Cabe señalar, que, aunque estos resultados atañen a la mayoría de los jóvenes de la muestra, algunos de ellos, tanto en el sondeo exploratorio como en el cuadro de elementos significativos (instrumento 2) y mapa semántico (instrumento 3), varios de ellos tienen otras ideas sobre la categoría de felicidad y su subcategoría: bienestar. Lo que se evidencia en que, para algunos, es importante mostrar una foto de perfil en un día en el que en realidad se hayan sentido felices, es decir, no solamente aparentarlo: "Estar feliz en el momento en que tomé la foto y el día completo, porque si lo subí, son por algo importante o feliz de mi vida" (sondeo exploratorio, hombre de 15 años). Lo que nos lleva a pensar que es preciso tener en cuenta que, a pesar de que exista una mayoría de jóvenes de la muestra que manifiesta las representaciones sociales identificadas y 
descritas, existe otro grupo entre ellos, que presentan puntos de vista que no van de la mano con los de la mayoría.

Otro elemento de la representación en cuestión es el de la necesidad de demostrar a los demás que se tiene capacidad adquisitiva. Este aspecto de la representación (periférico, pero cercano al núcleo) se conecta con la tendencia de varios jóvenes a mostrar que son felices porque pueden ir en consonancia con las vanguardias del mercado. Lo que se observó cuando señalaban a la ropa nueva y a la moda en conexión con parecer felices y, a esto último, con la estética.

De todas maneras, la moda no fue un elemento demasiado señalado. De hecho, no obtuvo un porcentaje muy alto de menciones de los jóvenes en el instrumento dos ; sin embargo, sí hace parte de los elementos periféricos de la representación de apariencia de felicidad $\left({ }^{26}\right)$.

Otra de las formas de estar a la moda que señalaban los jóvenes, era utilizar en la edición de sus fotos los programas y aplicaciones más actualizadas para elaborarlas lo mejor posible. Dichas herramientas virtuales, permiten a los jóvenes incluir en sus fotos no solo la ropa, maquillaje, accesorios físicos que tienen a la mano, sino otros virtuales que utilizan para embellecer las fotos.

El uso frecuente y "novedoso" de esos accesorios, sobre todo los virtuales, provee al joven de otro elemento con el que asocia el parecer feliz: ser creativo y tener la habilidad de editar y transformar sus fotos al punto de que estas tengan apariencia de belleza.

\footnotetext{
${ }^{26}$ Como se muestra en la figura 1
} 
Es decir, se es más creativo entre más elaboradas estén las fotos que se publican en sus perfiles. La creación de fotos llamativas se conecta para varios de los jóvenes con la posibilidad de demostrar felicidad. Dichas fotos tendrán a su vez más apariencia de belleza, si no son opacas o demasiado simples. En el caso de las mujeres, prefieren las fotos coloridas; el hombre opta por utilizar fondos iluminados.

Por supuesto, existen jóvenes dentro de las muestras que tienen otras perspectivas frente a la conexión estética-felicidad, como se fue describiendo y ejemplificando en cada instrumento, debido a que conectan el verse felices en la foto de perfil con sus experiencias personales.

\subsubsection{Representación social: apariencia de belleza.}

En esta representación nuevamente encontramos el verbo aparecer. La belleza, el verse lindo(a) en una foto se conecta no con ser, sino con mostrar a los demás que se es bello. A su vez, parecer bello se lograría en las fotos de perfil siempre y cuando el joven se acerque a un modelo de perfección construido culturalmente.

El núcleo de la representación de apariencia de belleza estaría precisamente en esa aspiración a verse perfecto, de acuerdo a la apariencia deseada. Observemos las cadenas asociativas que se expresan jerárquicamente en la figura que sigue: 


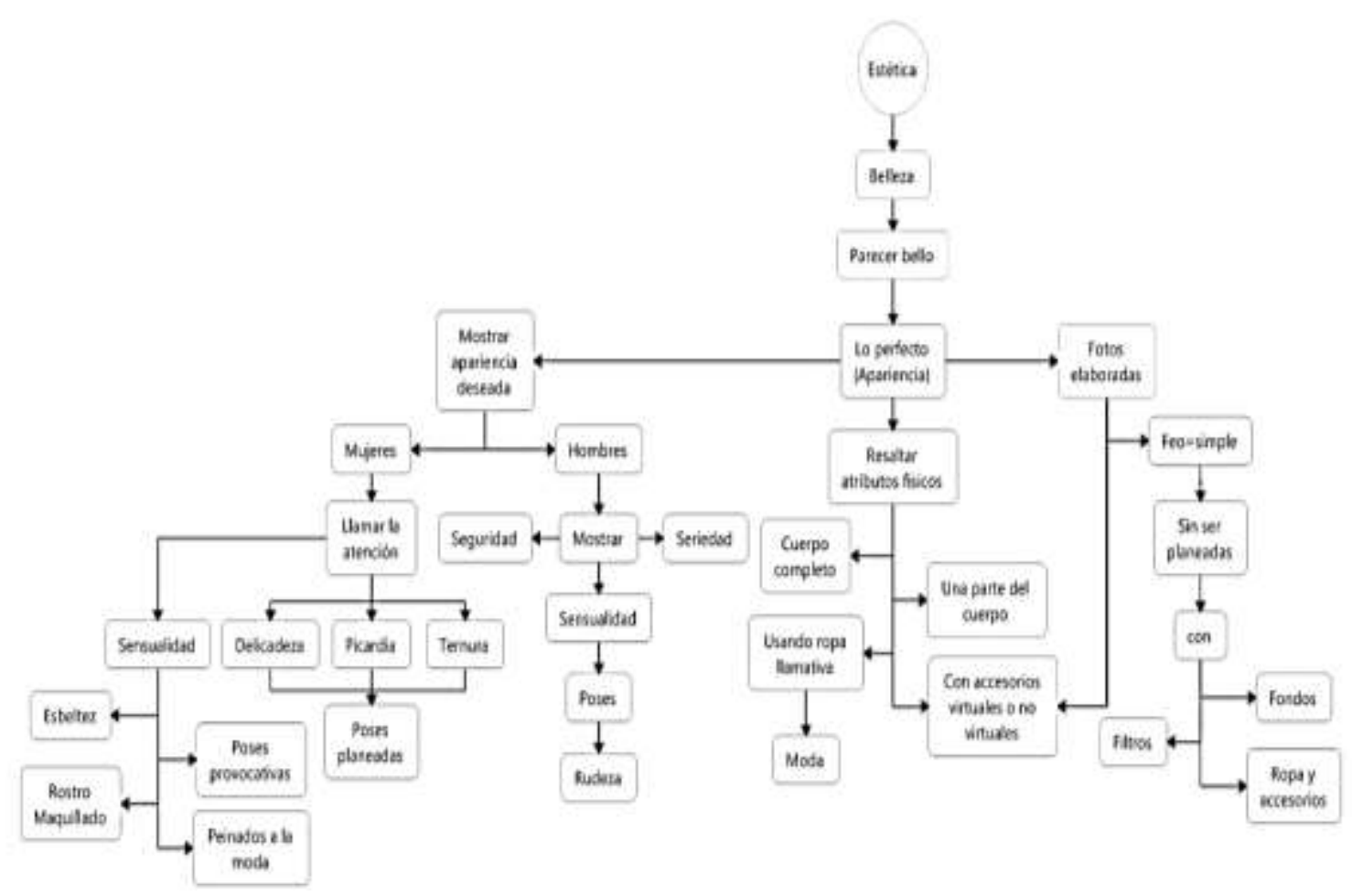

Figura 2

Mapa conceptual organización y jerarquía de la representación social: apariencia de belleza

La perfección (núcleo de la representación) se buscaría ante todo para llamar la atención. Para hacerlo, se utiliza: ropa, accesorios virtuales y no virtuales llamativos. En algunos casos, los jóvenes señalaban que les gustaba verse elegantes. Además, expresaban que les agradaba realizar gestos que demostraran confianza y seguridad en sí mismos. Lo que importaba era demostrar esas características. Salvo en pocas ocasiones, en que algunos jóvenes resaltaban la importancia de tener realmente las características que mostraban en sus fotos de perfil.

Otra de las formas de demostrar la perfección con relación a la apariencia deseada en las mujeres, es mostrar cierta delicadeza. Es decir, se privilegia la imagen de una mujer 
que combina la delicadeza con una picardía sutil. En las muestras recogidas, esa sutileza se evidenció en el hecho de que, no es usual que hombres o mujeres refieran de forma directa que desean verse sexys en sus fotos. Sin embargo, sí decían que deseaban llamar la atención del sexo opuesto a partir de ropa, accesorios y poses que se conectan con la atracción física.

Otro elemento periférico interesante con relación a esta representación, es la preferencia de las jóvenes por verse tiernas. Lo que se lograría a través de recursos corporales como gestos, poses; además del uso de accesorios, fondos y filtros que logran el efecto de suavizar la foto.

En contraste, varios hombres conectan la apariencia deseada con la perfección, pero a partir de fotos de perfil que muestren cualidades como la seriedad y seguridad.

La sensualidad también juega un papel importante en la representación sobre la apariencia de belleza en el caso de los hombres, pero no tanto en conexión con la visibilidad como en las mujeres. El hombre sería sensual siempre y cuando, además de tener algunos atributos físicos, demuestre cierta rudeza, aspecto que se logra sobre todo con poses y gestos. Lo curioso es que pocos hombres señalan que realizan sus poses para verse sexys. Se trata, como en el caso de las mujeres, de una sensualidad que se presenta en las fotos, pero que no se acepta abiertamente.

Otro de los elementos cercanos al núcleo de esta representación $\left({ }^{27}\right)$ es resaltar atributos físicos. Algunos de los elementos con los que se busca sobresalir es el cuerpo, sea completo o solo una parte específica y, por tanto, focalizada en la foto. En ocasiones, el

\footnotetext{
${ }^{27}$ Ver figura 1
} 
mecanismo que se usa para lograrlo es para ambos sexos el de la ropa, accesorios virtuales y no virtuales y, en algunos casos, la moda, mostrando que se está a la vanguardia con las nuevas tendencias.

El tercer elemento más cercano al núcleo de esta representación, es el que conecta a la perfección con la capacidad de producir una foto de perfil muy elaborada, es decir con un muy buen trabajo de edición. Se valora el producto final de un proceso más bien técnico de producción de fotos consideradas bellas. Para ello, se valoran las fotos que están bien planeadas y tienen los filtros, fondos, accesorios virtuales y no virtuales, ropa, etc., que se ajustan al ideal de belleza-perfección que se comparte socialmente.

\subsubsection{Representación social del reconocimiento.}

Esta representación está materializada por el interés de ser reconocido por los demás, a través de fotos de perfil que cumplan con el objetivo de generar visibilidad (núcleo de la representación). Al ser visible, se logra despertar la atención de los otros. Si esto ocurre, se considera al joven más atractivo, $y$, serlo, se conecta a su vez con aparentar más felicidad. Como se puede notar, las representaciones sociales descritas hasta ahora empiezan a conectase significativamente.

El que otros se interesen por las fotos de los jóvenes y lo demuestren a partir de los likes y comentarios, es lo más importante para ser aceptado por otros, especialmente por los pares. Contrario a ello, la ausencia de esos indicios de reconocimiento, se tiende a asociar con invisibilidad social, lo que usualmente se traduciría en ver desmejoradas las relaciones sociales del joven tanto dentro como fuera de Facebook. 
Lo estético, se conecta entonces con ser reconocido y, para ser reconocido, se debe lograr la visibilidad. Veamos ahora cómo ese núcleo se va conectando con sus elementos periféricos y las jerarquías entre estos:

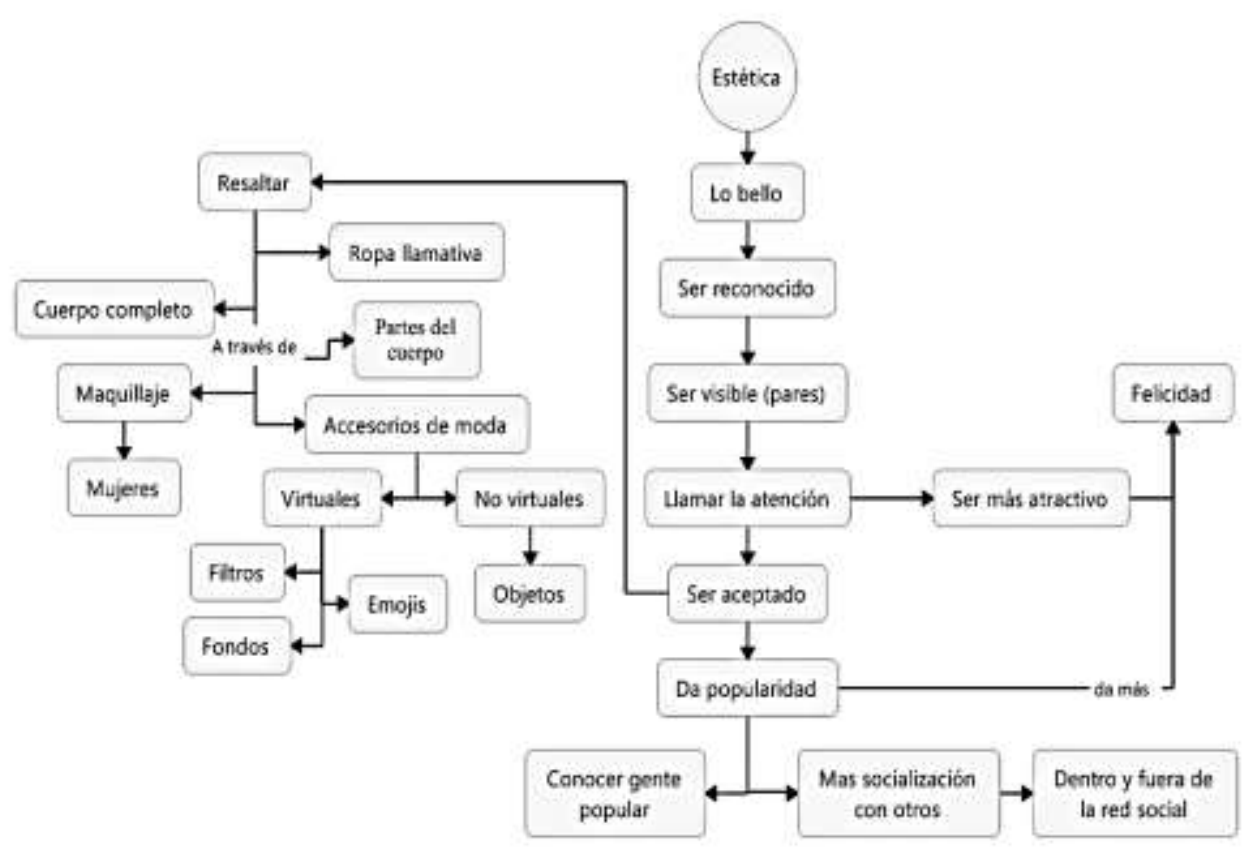

Figura 3

Mapa conceptual organización y jerarquía de la representación social: reconocimiento

Para ser aceptado por los demás, se busca trabajar en el diseño de fotos de perfil que muestren ropa llamativa (preferiblemente si es nueva o está de moda), el cuerpo completo o partes de este, maquillaje (en el caso de las mujeres), accesorios (virtuales y no virtuales). Adicional a ello, las posturas corporales también son ensayadas de antemano para cumplir con el objetivo de resaltar para ser aceptado. Y, ser reconocido es una parte fundamental de ser bello. 
Como ejemplo de lo anterior aquí aparecen algunos de los elementos significativos que señalaron los jóvenes en el instrumento dos:

Lapicero: "me gusta cómo resalta y se ve cool" (hombre de 15 años).

Cámara de abajo hacia arriba: "para que se me vea todo el cuerpo" (mujer de 14 años).

Cabello al frente: "porque realza mi cara" (mujer de 15 años).

Blusa descotada: "realza mi cuello y muestra parte de mi pecho" (mujer de 16 años).

Se puede pudo observar cómo la tendencia a llamar la atención a partir de ropa, accesorios y poses es más común en la mujer. Aspecto que se analizó más arriba cuando se señaló que el porcentaje de palabras relacionadas con visibilidad era mayor que en el caso de hombres. Sin embargo, esto no quiere decir que los hombres no busquen la visibilidad llamando la atención a través de fotos elaboradas, solo que en el caso de las mujeres es más notorio.

Ahora, si un joven logra llamar la atención de los otros, esto le genera aceptación y esta, a su vez, popularidad; es decir la posibilidad de conocer más personas que gozan de mucho reconocimiento y socializar más con ellas.

\subsubsection{Representación social: personalización.}

La belleza también es asociada por los jóvenes con lograr, a través de sus fotos de perfil, una imagen bastante personalizada de sí mismos, para diferenciarse de los demás. La personalización, es de hecho un concepto acuñado por Lipovetsky (2003) para referirse a la tendencia de las personas en la sociedad contemporánea, por valorar 
positivamente todo aquello que les permita imprimir su individualidad en cada aspecto de la vida cotidiana. En este trabajo se retoma dicho concepto en relación a cómo los jóvenes se esfuerzan por demostrar que tienen un estilo propio; es decir, acorde con los gustos y preferencias personales de cada uno. Muchos de los esfuerzos en la elaboración de las fotos que realizan los jóvenes, están enfocados precisamente en ese interés de diferenciarse, de desmarcarse de los otros. De ahí que, precisamente, la diferenciación es el núcleo de la representación que nos ocupa. Veamos ahora cómo se van organizando jerárquica y significativamente los demás elementos de dicha representación: 


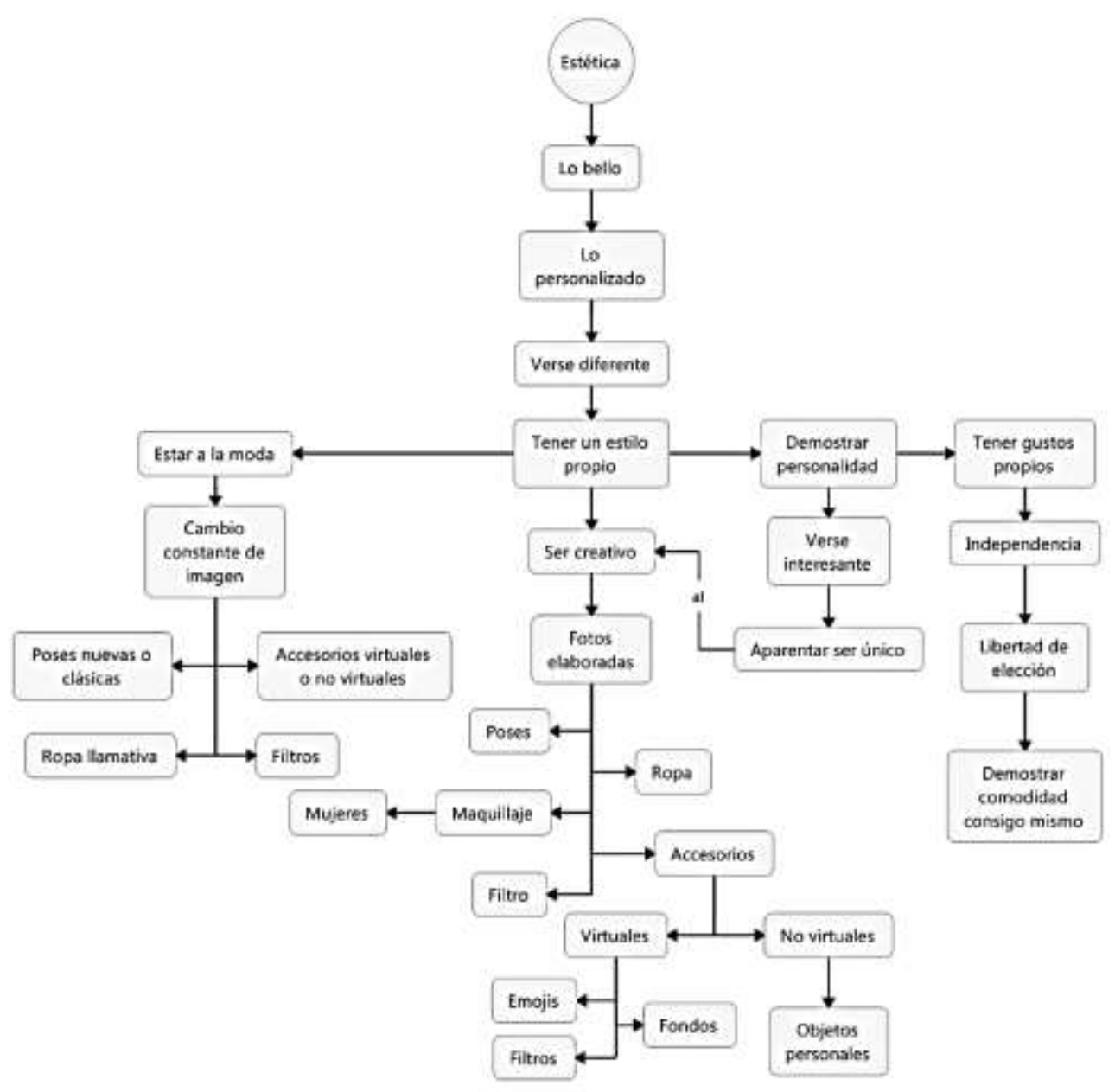

Figura 4

Mapa conceptual organización y jerarquía de la representación social: personalización

Ese estilo propio se compone de tres elementos centrales. El primero se conecta con la moda. Claro está que con moda no se entiende únicamente a las nuevas tendencias en ropa o accesorios. Para el joven, estar a la moda consiste también en estar renovando constantemente su imagen personal, en este caso específicamente la que presenta en sus 
fotos de perfil, por ejemplo, usando poses nuevas, gestos o accesorios virtuales como los emojis.

Resalta en este aspecto la necesidad de cambiar, de lucir constantemente diferente. Por eso, muchos jóvenes modifican sus fotos de perfil varias veces, incluso en la misma semana. El segundo elemento vinculado con el estilo propio, tiene que ver con la valoración que se hace de la creatividad que demuestran los jóvenes en las producciones de sus fotos de perfil. Entre más elaboradas estén estas y más incluyan los gustos personales de cada joven, son consideradas más únicas, $\mathrm{y}$, por tanto, más bellas.

El tercer elemento con que los jóvenes conectan tener estilo propio es el de demostrar personalidad y buen gusto. Esto se lograría siempre y cuando el joven logre verse interesante para los demás. Objetivo que se consigue cuando las fotos que se publican son únicas. Y, estas, a su vez lo serán si el joven plasma en ellas sus gustos y preferencias personales que, entre más diferentes sean a las del resto, más independencia reflejan. Se trata de mostrar a los otros que se tiene la potestad para escoger las opciones de personalización de sus fotos que más se acomodan con la personalidad de cada uno y con las que se siente cómodo consigo mismo, pero sobre todo en relación con los demás, a quien se intenta gustar.

Llama la atención cómo algunos de los jóvenes señalaban que verse diferentes resultaría interesante para los demás, en quienes esperaban generar una reacción premeditada por ellos en el momento de producir la foto. Algunos jóvenes escribían en el instrumento dos: 
Cadena en la oreja: "es un arete muy lindo y diferente. Me hace ver extrovertida" (mujer de 14 años)

Mano en la cara: “un lindo gesto y único” (mujer de 15 años. Instrumento 2)

Mirada al piso: "quería verme un poco intelectual” (hombre de 16 años. Instrumento 2)

En algunos casos se hacía referencia a las marcas y a estar a la moda paradójicamente como a un elemento de diferenciación:

Camisa y tenis: "en ese momento con la ropa de Adidas me veo interesante" (hombre de 15 años. Instrumento 2)

Moda y diferenciación estarían conectados para los jóvenes a través del estilo. Lo anterior, porque estar a la moda, se relaciona mayoritariamente con mostrar los gustos propios, las elecciones personales que hace cada uno de los recursos (ropa, accesorios, peinados, posturas corporales, etc.,.) que usará en la elaboración de fotos de perfil que sean capaces de gustar a los demás.

Por supuesto que no en todos los casos el estilo propio de los jóvenes se conecta necesariamente con asumir lo que está de moda sin modificaciones por parte de los jóvenes. Algunos de ellos referenciaban en ambos instrumentos, que les gustaba incluir fotos de perfil que contenían elementos significativos en sus vidas y que representaban su estilo e historia personal. En otros momentos señalaban cómo ellos mismos realizaba modificaciones de las tendencias de moda en ropa, accesorios y les imprimían su propia versión.

De acuerdo a los datos obtenidos con el instrumento dos, existiría una tendencia un poco más marcada en las mujeres por querer personalizar sus perfiles, usando para ello 
ropa, accesorios (virtuales y no virtuales), poses, obteniendo un 46,7 \%, frente a un $33,3 \%$ de los hombres, quienes utilizan recursos parecidos. Sin embargo, como se puede observar, en esta representación están un poco más cercanos los porcentajes entre hombres y mujeres. Ambos géneros valoran mucho la creatividad para mostrar de forma auténtica aspectos de la vida cotidiana a través de la imagen, de modo que estos llamen la atención y se logre el reconocimiento social.

\subsubsection{Conexiones entre las representaciones sociales de la estética en jóvenes.}

Después de haber descrito las cuatro representaciones sociales acerca de la estética que tienen los jóvenes, se encontró que estas conforman una forma específica de narraciones que se cuentan los jóvenes así mismos sobre cómo funcionan aspectos tan fundamentales en su vida social como lo son: lo bello, el reconocimiento social, el estilo personal, la felicidad.

Esas narraciones que circulan entre los jóvenes podrían partir de cualquiera de las representaciones sociales de la estética, porque están relacionadas de una forma circular. Observemos detenidamente la figura que sigue en donde aparecen esas conexiones: 


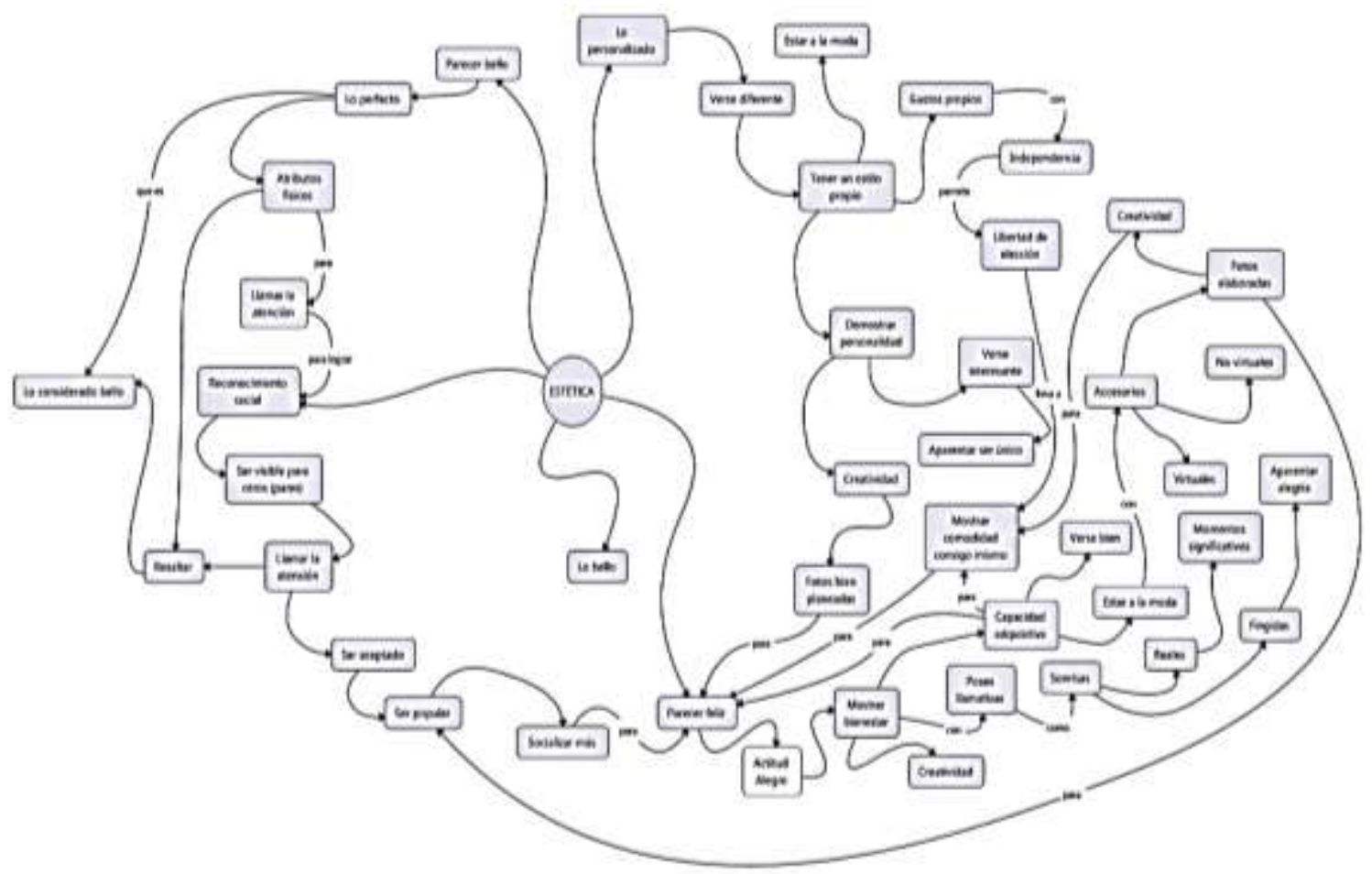

Figura 5

Mapa semántico. Conexión entre las representaciones sociales de la estética en los jóvenes.

Si decidiéramos partir nuestra lectura del mapa de los enlaces entre representaciones, por ejemplo, desde la de apariencia de belleza, tendríamos un relato que se podría resumir así: parecer bello implica verse en las fotos de perfil acorde con unos atributos sociales y culturales que socialmente se han ido aceptando. Es decir, acercarse a lo que culturalmente se entiende por belleza perfecta. A su vez, esa perfección implica que el joven demuestre que tiene la creatividad para crear y mostrar a los demás una versión personalizada de sí mismo en su perfil. Lo anterior, significa que tiene la libertad para elegir cómo mostrarse a los demás desde sus propios gustos. Lo que implica que tiene un estilo propio y, que, por tanto, se siente cómodo consigo mismo. Si lo está y, además, elabora sus fotos usando todas las técnicas y tecnologías que tiene a la mano, tales como: 
accesorios (virtuales y no virtuales), ropa y posturas corporales, va a parecer más feliz y, por tanto, sus fotos serán más bellas. Lo que le hará ganar popularidad. Por supuesto, siempre existirán los momentos realmente significativos, en donde el joven no solo parece feliz, sino que afirma haberlo estado, funcionando la foto de perfil en este caso como un recurso de la memoria. De cualquier forma, si el joven se ve feliz, atraerá comentarios favorables y más "me gusta”, siendo así más aceptado socialmente. Si además de esto, las fotos demuestran estar bien elaboradas con los recursos disponibles tanto en lo virtual como en lo no virtual, llamarán más la atención y, por lo mismo, gustarán más a los demás. Con lo que se ganará más visibilidad y, por tanto, el reconocimiento social del joven aumentará. Dicho reconocimiento hace que las fotos sean más bellas, y estas son bellas en la medida en que llaman la atención. De ahí podríamos volver a empezar el recorrido por las cuatro representaciones sociales. Incluso se podía empezar el relato desde cualquiera de ellas. Las conexiones volverían a aparecer, solo que iniciando desde otro ángulo. De ahí que se hayan graficado a través de un mapa semántico $\left.{ }^{28}\right)$, cuya forma ovalada nos permite comprender cómo las representaciones están fuertemente enlazadas y reforzadas entre sí.

\footnotetext{
${ }^{28}$ Ver figura 5
} 


\section{Capítulo VI. Discusión de resultados}

Para abordar el objetivo número tres de esta investigación, a saber: analizar las representaciones sociales de la estética que tienen los jóvenes, manifestadas a partir los significados que dan a los indicadores corporales que muestran en sus fotos de perfil en Facebook, se presenta el análisis de las mismas, en dialogo con algunos de los autores que fueron fundamentales para este trabajo.

Para los jóvenes, verse bello en sus fotos de perfil se conecta en gran medida con mostrar actitudes alegres que, a su vez, implicarían que se tiene un bienestar. Lo que no implica necesariamente haber estado alegre, ni tener dicho bienestar en realidad; lo que cuenta es que los otros así lo vean a través de fotos que están intencionalmente elaboradas para cumplir este objetivo. De ahí que lo usual es que se publiquen fotos en donde las imágenes sugieran que se estaba teniendo un buen momento.

De hecho, publicar fotos en donde el joven se encuentre en un estado de enfermedad o que su actitud no sea de alegría, no son las más usuales por lo menos no en la muestra de los jóvenes participantes en este estudio $\left({ }^{29}\right)$. Lo frecuente es que los jóvenes muestren fotos de sí mismos en donde aparecen sonrisas que proyectan bienestar (Dillon, 2013).

Lo interesante es notar cómo algunos de los estereotipos de belleza que se presentan en los medios, sobre todo en la publicidad, en el cine, entre otras industrias culturales a las que acceden los jóvenes, coinciden con esta tendencia. Lo usual en estos espacios mediáticos es de hecho presentar la imagen de una mujer provocadora, capaz de mostrar

29 No usuales por lo menos en la muestra de los jóvenes participantes en este estudio. 
una imagen sonriente y esbelta. En oposición a ello, tenemos la imagen del hombre, quien se convierte en el consumidor por excelencia de imágenes que apelan a su instinto. El hombre, en la mayoría de comerciales, series y películas se presenta como a un ser poderoso, serio y capaz de demostrar su virilidad a partir de sus poses y actitud segura. Por supuesto, esto no se ve en todos los casos, ni en todas las producciones mediáticas, pero sí en una gran parte. Al respecto Sibilia (2008) afirma que, cada vez más, los sujetos intentan parecerse en mayor medida a los protagonistas de las producciones mediáticas, específicamente a las de los videos que circulan por la red. De ahí que muchas de las poses, gestos, ropa y accesorios que se usen, tengan un punto de referencia en esos modelos estéticos mediáticos generalizados (Sibilia, 2008).

Ahora, sin el ánimo de afirmar tajantemente que la diferencia entre la importancia que se da a la seriedad y a la sonrisa en cada género depende únicamente de los modelos mediáticos, sí podemos decir que puede existir una conexión entre la organización de estos elementos de la representación de apariencia de felicidad, con la cantidad de imágenes e información en general que reciben a diario los jóvenes a partir de los medios.

De todas maneras, cabe destacar que las sonrisas que muestran los jóvenes en sus perfiles, aunque en buena medida, son fingidas (según lo señalaban ellos mismos en los instrumentos uno y dos) existe otro tipo de sonrisa que se conecta con querer mostrar a los demás momentos que en realidad fueron significativos para ellos. En este caso Facebook, específicamente el espacio de perfil, funciona como un diario virtual, en donde el joven consigna y comparte recuerdos con los otros, especialmente los que fueron significativos $\mathrm{y}$ felices. Lo que implica que redes sociales como Facebook, 
también se están utilizando actualmente por los jóvenes como confesionarios en donde se consignan experiencias significativas. Con la diferencia de que no siempre los diarios eran escritos en el pasado para ser compartidos abiertamente con el público, como ocurre hoy en día (Sibilia, 2008).

Interesa tratar de identificar qué otros factores culturales se relacionan con la configuración de la representación que nos ocupa. Para hacerlo, tenemos que analizar primero qué aspectos se conectan actualmente con felicidad en la sociedad a la que pertenecen los jóvenes. En primer lugar, la felicidad se enlazaría con la satisfacción de los deseos aquí y ahora (Bauman, 2007). La recompensa inmediata está a la orden del día, así que por ejemplo si un joven publica una foto y no recibe los suficientes likes con la rapidez esperada, es posible que opte por cambiar su imagen de perfil.

Como la intención de muchos jóvenes es mostrarse alegres y que se tiene un bienestar, cabe preguntarse cómo se puede comprender este concepto hoy en día.

Desde Bauman (2007), en la sociedad de consumidores el bienestar se vincula con la capacidad de consumir; de ser consumidores válidos porque se poseen los recursos para ir a la vanguardia con las tendencias del mercado. En el caso de los jóvenes de esta investigación, la situación económica les asegura un acceso limitado a ciertos elementos de distinción social demasiado costosos, tales como ropa de marca, viajes al extranjero, objetos de cuantiosa valía. Sin embargo, la moda y el mostrar a los demás que se tienen unos zapatos o celular de marca, sí aparece en algunas de las muestras que se recogieron. Lo que implica que sí existe una valoración de la distinción con respecto a los otros, cuando pese a no contar con grandes recursos económicos, se logra aparentar felicidad mostrando que se han adquirido tales objetos. 
Algunos de esos accesorios que se utilizan en las fotos no son necesariamente materiales. Hoy en día, gran parte de estos son virtuales. Lo que implica que un joven, sin necesidad de contar con demasiados recursos económicos, puede construir una foto de perfil que incluya accesorios y ropa de moda, filtros y fondos, que le permitan no solo dar apariencia de felicidad, sino demostrar su creatividad a la hora de elaborar sus fotos de perfil. Precisamente, este es otro de los elementos que conforman a la representación de apariencia de felicidad. El joven será capaz de lucir más bello en las fotos, siempre que demuestre que es lo suficientemente creativo como para crear una imagen de sí mismo que se aleje de la simplicidad o de lo opaco; es decir de lo que no demuestra una actitud de alegría y que se considera poco atractivo. Ahora, nunca se logra una satisfacción total con las fotos. Siempre se están renovando las técnicas para verse más feliz, para demostrar un mayor bienestar a los demás. Sin embargo, ese deseo de plenitud con la propia imagen se ve defraudado por las exigencias cada vez más exigentes del mercado frente a lo que implica verse feliz (Bauman, 2007).

Demostrar bienestar se convierte cada vez más en una tarea complicada, en una sociedad en donde cada día aumenta el listado de necesidades que un ser humano promedio tendría que satisfacer para acercarse a la perfección estética.

Ser bello parece ser hoy en día menos relevante que parecerlo. Para los jóvenes, esta realidad se convierte en el modus operandi que llevan a cabo en Facebook, en donde retocar y elaborar sus fotos para que parezcan bellas, es más bien algo común.

Esa apariencia de belleza es una representación social cuyo núcleo es la búsqueda de perfección. Lo que lleva a pensar bajo qué modelos a seguir se está interpretando ese verse perfecto, o, por lo menos, acercase a ello. Frente al tema, Sibilia (2008) apunta 
cómo hoy en día, gran cantidad de personas anhelan parecerse lo más posible a los modelos mediáticos que aparecen a diestra y siniestra en la publicidad, en la televisión, en las diferentes páginas de internet que se visitan a diario. No es diferente en el caso de los jóvenes, quien todo el tiempo están expuestos a un sinfín de estímulos mediáticos que les están sugiriendo todo el tiempo cómo luce una persona bella; es decir qué considerar bello y, por tanto, social y culturalmente aceptado. Bauman (2007) señala al respecto que, en la sociedad de consumidores, no importa tanto lo que se es, sino lo que se podría llegar a ser. Es decir, el cuerpo humano debe aspirar a una perfección que supla las necesidades estéticas del consumo. El problema estriba en que siempre surgirán nuevas exigencias estéticas que hacen que ese proceso nunca se cierre. Además, si aquellos cuerpos que no se modifican constantemente para acercarse cada vez más a los ideales de belleza mediáticos, estarían condenados a ser señalados por su simpleza y fealdad (Bauman, 2007).

La perfección, núcleo de la representación que nos ocupa, al estar conectada con la belleza, remite directamente al momento histórico, social y cultural en el que se esté inmerso. De ahí que aquellos atributos físicos que se consideren atractivos, están contextualmente situados (Vigarello, 2005). Por lo que aspectos como el buen gusto y los criterios estéticos con que se valoran, por ejemplo, las fotos de perfil en Facebook, tienen una relación directa con el entorno en el que se desenvuelven los jóvenes. Y, si ese entorno está fuertemente atravesado por los discursos mediáticos que circulan desde los medios de información, especialmente Internet (Baricco, 2008; Morduchowicz, 2012; Pisticelli, 2009; Urresti, 2008), podemos afirmar que la representación de apariencia de 
belleza, está fuertemente estructurada partir de los discursos imperantes sobre lo bello que se manejan desde los entornos virtuales.

No es difícil relacionar algunas de las imágenes que se consideran bellas por los jóvenes, con el tipo de belleza que se promulga a partir de los medios. Muchos jóvenes, sobre todo en occidente, están expuestos al estereotipo de mujeres sensuales que exhiben sus delgados y torneados cuerpos u hombres que se muestran atléticos, en ocasiones algo rudos, pero, de cualquier forma, interesantes. Imágenes en donde las imperfecciones no existen. $\mathrm{O}$, por lo menos, no se muestran porque, de lo contrario, la imagen no vendería igual. En las fotos de perfil que exhiben los jóvenes, esta relación entre belleza y perfección asume al parecer la misma lógica.

Solo aquellas imágenes que se asemejan a los modelos de perfección que promueven los medios y el mercado son capaces de vender. En este caso, logran ser reconocidas y aceptadas por los demás.

Para lograr ese efecto, los jóvenes se valen de un sinfín de estrategias que utilizan para elaborar sus fotos de perfil, de modo que estas resulten más atractivas a la vista. En el caso de las mujeres, existe una mayor tendencia a querer llamar la atención luciendo un cuerpo esbelto y a resaltar a partir del uso de ropa, maquillaje, accesorios virtuales y no virtuales que las hagan sobresalir. Industrias culturales como el cine, por ejemplo, han aportado en la normalización de ideales de belleza que apuntan a cuerpos de mujeres increíblemente delgados y casi inverosímiles e inalcanzables para buena parte de las personas del común.

La belleza se ha venido normalizando como una imposición para las mujeres, quienes son reguladas constantemente por los imperativos que se le instauran desde las 
hegemonías, quienes tienden a regular a las mujeres y a sus prácticas a través de mecanismos mediáticos (Muñiz, 2014), haciéndoles creer que tienen la libertad para escoger cómo desean verse, cuando lo que se hace es replicar los cánones de belleza que reproducen el sistema económico imperante.

Por supuesto que para los hombres también existen unos ideales de belleza, que se promulgan y reproducen en lo social. No obstante, el imperativo de belleza para lo femenino es sobresaliente y se basa en una serie de normas estéticas que determinan si un cuerpo es o no viable en una determinada cultura (Muñiz, 2014).

De ahí que social y culturalmente para las mujeres sea más relevante ser visibles que para los hombres. Se espera llamar la atención por el atractivo físico. Verse perfectas. Mostrar un cabello hermoso, un maquillaje y accesorios que realcen su cuerpo y llamen la atención no se aleja mucho de la imagen de la mujer que aparece en la publicidad, en ocasiones incluso para vender los artículos menos aparentemente conectados con este tipo de imágenes. El imperativo social y cultural que exige a la mujer convertirse en un producto deseable, y, por tanto, consumible, se proyecta en esa ansia de las jóvenes por llamar la atención y parecerse a esos modelos de esbeltez que se promulgan mediáticamente.

Los hombres, por su parte, serían más bien consumidores de esas imágenes en donde se promulga la sensualidad femenina como una poderosa arma de persuasión comercial. Sin decir con ello, que los hombres dejen de producir imágenes llamativas y comercializables, ni que las mujeres para nada consuman de todo tipo de imágenes. Sin embargo, culturalmente, la mujer aparece más frecuentemente como ese objeto del deseo. Aspecto que se percibe en la mayor cantidad de imágenes sensuales femeninas 
que utiliza la publicidad, el cine, entre otras industrias culturales para vender sus productos. Es decir, el mercado sería más enfático en que la mujer debe verse bonita, llamar la atención y consumir objetos y productos que realcen su belleza (Muñiz, 2014).

Muchas clientas de dichos productos son, en su mayoría, mujeres. Gran cantidad de dietas, cremas, aunque están destinadas para hombres y mujeres, utilizan frecuentemente la imagen esbelta y sensual de las mujeres para generar un impacto visual. Lo que podría estar impactando al tipo de representaciones estéticas que tienen los jóvenes y que se materializa en las fotos de perfil que publican en espacios virtuales como Facebook.

En dichas fotos, los jóvenes muestran lo que Bonacci (2013) denominó: la mejor cara. Es decir, aquella que les permite ser aprobado socialmente. Parecer bello le permite al joven obtener un reconocimiento social que se desprende de que su imagen pública en la red logra ser competitiva en el mercado de las miradas (Sibilia, 2008). Espacio en el que circulan esas imágenes-objeto de consumo (Bauman, 2007) en que se convierten las fotos de perfil actualmente. Por supuesto, según se describió y ejemplificó en la presentación de resultados, la concepción de lo que es la estética y la manera en que algunos jóvenes se presentan en sus perfiles no en todos los casos coincide con la necesidad de parecer bello. Existen jóvenes que no elaboraban sus fotos de perfil porque desearan que otros los aceptaran. Más bien, se referían a lo estético como a la posibilidad de expresar sus emociones, sentimientos e identidad personal, de formas que no necesariamente correspondían con los ideales estéticos de la mayoría. De hecho, algunos de ellos apreciaban las imperfecciones como algo que era constitutivo de su naturaleza y, que, por tanto, podía ser parte de aquello con lo que se identificaban. Otros afirmaban que no les gustaba editar tanto sus fotos, porque querían que los apreciaran por lo que 
eran y no por lo que aparentaran ser. Estas posturas, aunque no reflejan los resultados de la mayoría, no pueden ser invisibilidades en este estudio.

Por su parte, la representación de reconocimiento está conectada $\left({ }^{30}\right)$ con la visibilidad que buscan los jóvenes en Facebook. Esa visibilidad se dirige a llamar la atención de los otros, porque se considera que entre más reconocido se es, más felicidad se puede demostrar.

Llamar la atención de los otros se convierte en uno de los objetivos centrales en la elaboración de las fotos de perfil. La vida misma se empieza a concebir como el escenario de un espectáculo (Sibilia, 2008). Todos representan a las cámaras frente a las que es preciso exhibir la mejor cara (Bonacci, 2013). De ahí que la manera en que el joven se presente a sí mismo en su perfil, estará elaborada de modo que le permita ser aceptado por los demás. Y, para lograrlo, necesita que su imagen se parezca cada vez más a los cánones de perfección y belleza que se señalaban más adelante.

De ahí que la corporeidad que se muestra en esas fotos, sea intencionada. Es decir, lejos de que el joven aparezca de forma espontánea en la mayoría de sus fotos de perfil, se da todo un proceso de elaboración de esas imágenes en donde el joven busca ante todo el reconocimiento, sobre todo el de sus pares (Basile y Linne, 2014).

Ser visto sería igual a existir en la red social. De ahí que sean tan valorados los indicios popularizados de aceptación como el número de likes o comentarios que demuestren que se ha logrado gustar a los demás. Lo anterior, parte de las construcciones sociales y culturales que implican dar importancia a la opinión de los demás, como indicador sobre qué tan aceptado se es.

\footnotetext{
${ }^{30}$ Ver figura 3
} 
El ser reconocido por los demás, especialmente por los otros jóvenes, sigue siendo un imperativo a seguir, una regla que la mayoría de los jóvenes de la muestra reproducen en la forma en que se muestran a sí mismos en la red social. Lo anterior, porque se tiene la creencia de que el nivel de reconocimiento social que se logre en la red, influye en el tipo de relaciones que se establezcan con otros jóvenes dentro y fuera de lo virtual. Esto se identificó en algunas de las frases que escribían los jóvenes en los dos instrumentos, cuando decían, por ejemplo: "uso este accesorio para ser más popular" (hombre de 15 años. Instrumento2); "verme mejor me ayuda a conseguir más amigos" (mujer de 14 años. Instrumento 2).

Ser aceptado se lograría para ellos si se resalta con relación a otros. Para lograrlo, se hace uso de gran cantidad de estrategias virtuales y no virtuales, en donde la ropa, los accesorios y las posturas corporales cobran relevancia. Ser visible para los demás, implica ser deseado (Bauman, 2008). La imagen-foto se convierte en una mercancía que, al igual que en las lógicas del mercado, debe ser visible y altamente atractiva para los posibles compradores. Es decir, convertirse en un producto competitivo, capaz de despertar el deseo del consumidor (Bauman, 2008). En este sentido, ser reconocido se asemejaría a ser un producto en alta demanda.

Llama la atención cómo para las mujeres es más importante resaltar por la belleza de su cuerpo, por la pose que asume, por los accesorios y ropa que, para los hombres, aunque estos últimos también hayan indicado que les gustaba ser reconocido. Como el hecho de que, culturalmente, a la mujer se le valora más, en tanto demuestre poseer algunos atributos femeninos que resalten, llamando la atención del sexo opuesto (Muñiz, 
2014). En oposición a ello, tiende a no ser bien visto que una mujer descuide su aspecto físico, pues pareciera que social y culturalmente la mujer debiera adaptar su físico para gustar a los demás, especialmente de acuerdo a las exigencias y gustos normalizados (Muñiz, 2014). Por ejemplo, se promulga el ideal de mujer delgada, con el cabello sano y llamativo, que use maquillaje, ropa de moda que realce el atractivo femenino y una piel sin ninguna impureza. Por supuesto que el mercado se presenta como el gran salvavidas para ayudar a las mujeres a acercarse cada vez más a ese ideal. Si se requiere un cuerpo esbelto, aparece inmediatamente el comercial sobre los tratamientos de belleza para combatir la grasa o la crema adelgazante que se vende a precio increíblemente bajo, en comparación de lo que hará en beneficio de las mujeres. Obviamente, que esas exigencias de belleza perfecta hoy en día se han ido traspasando también a los hombres. De hecho, el mercado anuncia cada vez más frecuentemente nuevos productos para que ellos también puedan lucir más bellos. Sin embargo, y de acuerdo a los resultados de este trabajo, la condición de ser hermosa y, por tanto, llamativa, aún recae más culturalmente en la mujer (Muñiz, 2014), con el auspicio por supuesto del mercado y de sus estrategias mediáticas.

De cualquier manera, la mayoría de jóvenes de ambos géneros manifestaron dar importancia al reconocimiento social a partir de cómo se presentaran en sus fotos de perfil. Es decir, entre más reconocimiento, mayor valor social (Bauman, 2008) tiene el joven. Por el contrario, si no se logra la visibilidad en la red social, ocurriría lo que menciona Bauman (2007) con los consumidores fallidos. Existe un estigma social implícito de exclusión. Aquel que se le impone tanto a los productos, como a los no consumidores no aptos. Y, si la imagen del perfil no logra ser consumida y aceptada por 
la mayor cantidad de personas, no es un producto apetecible ni, por tanto, vendible. Lo que implica para muchos jóvenes un impacto negativo en su socialización con otros, dentro y fuera de la red. Por eso, para ellos es tan importante elaborar unas fotos de perfil que los diferencie de los demás. Lo que nos lleva a la representación que sigue. Ahora bien, en los datos obtenidos también aparecieron jóvenes que no parecían demasiado interesados en que sus fotos de perfil llamaran la atención o resaltaran frente a las de los demás. Por lo general, los jóvenes que tienen este tipo de opiniones, escriben que lo importante para ellos es sentirse a gusto consigo mismos, siendo la estética una forma de expresarse de diferentes maneras, que no buscan esa visibilización, como ocurre en la mayoría de los casos.

Con relación a la representación social de la personalización se puede decir que, en el contexto cultural en que nos desenvolvemos y, por supuesto, el de los jóvenes participantes de esta investigación, todo parece incitar a tomarse personal cada asunto de la vida. Ponle tu toque, sé creativo, agrega tu estilo, hazlo a tu gusto. Estas son las consignas que se escuchan por doquier, especialmente en las industrias culturales. Internet, por supuesto, no es la excepción. Cada día aparecen más y más aplicaciones que permiten a las personas transformar los espacios virtuales de acuerdo a su personalidad. En Facebook, no solo las fotos de perfil pueden ser elaboradas a gusto propio. También la arquitectura del sitio se presta para agregar un toque diferente a cada sección. Lo que habría que analizar es si realmente esa "libertad de elección" es tan libre como se promulga. Las aplicaciones que tienden a usar los jóvenes para editar sus fotos, parten de una variedad de opciones de personalización. Un ejemplo de ello está en aplicaciones bastante usadas por los jóvenes, en especial mujeres, como Snapchat, Sweet Selfie, 
B612, entre otras. Con estas herramientas, es posible realizar varios cambios a las fotografías. Se pueden agregar accesorios, fondos, colores. Incluso corregir “imperfecciones". Lo que llama la atención, es que los diseños mismos de este tipo de tecnologías, ya tienen implícitos unos cánones de belleza, porque las alternativas de escogencia de cómo personalizar las fotos ya vienen pre establecidos. Lo que significa que sí se daría a escoger al joven entre opciones par a poder verse "diferente", pero con limitadas alternativas que le apuntan a un modelo de belleza promulgado por industrias culturales como: el cine, la televisión, la publicidad, los estilos de algunos grupos musicales, entre otros.

La personalización es entonces una representación acerca de la estética cuyo núcleo es precisamente el ansia de verse diferente. Razón por la que, con vehemencia, tantos jóvenes utilizan técnicas cada vez más sofisticadas en la elaboración de perfiles que vayan de acuerdo con sus gustos. De hecho, en Facebook el usuario está valorando todo el tiempo las imágenes que ve a partir de la subjetividad. "Me gusta". "No me gusta". Todo se valora desde el yo, a quien, por lo menos en apariencia, se da la potestad de ser lo suficientemente creativo como mostrar sus propios gustos y estilo propio en las imágenes que publica. Aparentemente, en este tipo de espacios se apuntaría a la autenticidad, porque el principal protagonista es el usuario.

Al respecto Bauman (2007), Lipovetsky (2003) señalan cómo en la lógica consumista, el usuario tiene una supuesta soberanía que le permite elegir libremente el tipo de productos, servicios a los que accederá, entre otros aspectos cotidianos de su vida. Sin embargo, advierten cómo aquello que desde el mercado se pretende visibilizar 
como una oportunidad de elección, es más bien una obligación. El usuario está condenado a elegir. Para hacerlo, tiene a disposición una serie limitada de posibilidades. En el caso de la estética, los jóvenes supuestamente imprimirían en sus perfiles su estilo personal. Además, están impelidos a hacerlo. En la actualidad las fotografías se reconocen como bellas, si son elaboradas o, por lo menos, cumplen con unos ideales estéticos que no ha escogido precisamente el joven.

Sin embargo, en el discurso de los jóvenes sí se lee la intención por diferenciarse, por dotar de su estilo y personalidad cada foto que publica. Incluso, aspectos como la moda, se conectan en varios casos con verse diferente. Lo que resulta paradójico en tanto, en el fondo, la moda se sustenta en la estandarización de modelos de estilo y belleza.

El verse diferente reposa además en la idea de elaborar un producto tan atractivo y competitivo, que su demanda sea alta. Es decir, sea reconocido. El consumidor convertido en imagen se convierte en producto (Bauman, 2007). Allí, entre más "auténtica" parezca la foto-producto, más valorada será. Sin embargo, dicha autenticidad tan promulgada por el mercado, rara vez desborda los linderos de las estéticas dominantes y normalizadas. Sin embargo, cabe preguntarnos si ocurre esto en todos los casos. En realidad, este estudio muestra cómo una parte de los jóvenes de la muestra opta por concebir a la estética desde otro punto de vista, más conectada con la expresión de sus sentimientos y emociones. De hecho, tal como se ejemplificó en la presentación de los resultados, algunos jóvenes no suelen modificar demasiado sus fotos. En ellas tienen en cuenta ciertos momentos significativos para ellos, sin estar conectados con ideales mediáticos de belleza. Es importante hacer esta salvedad, en tanto, aun no 
siendo mayoría, existen jóvenes que están asumiendo otras posibilidades estéticas y lo demuestran en espacios variados, entre ellos, Facebook.

Otro de los elementos periféricos de la representación de personalización es el de la creatividad. Se insta al joven a utilizar las herramientas que brinda el mercado para crear un estilo propio con las opciones limitadas que se le ofrecen. Al respecto dice Sibilia (2008):

¿Qué implica este súbito enaltecimiento de lo pequeño y de lo ordinario y de la gente común? No es fácil comprender hacia donde apunta esta extraña coyuntura que, mediante una incitación permanente a la creatividad personal, la excentricidad, y la búsqueda de diferencias, no cesa de producir copias descartables de lo mismo (Sibilia, 2008, p. 12)

Se señala cómo a partir de una tendencia por la personalización, se exacerba un individualismo que apunta a que los sujetos demuestren una gran creatividad al crear objetos, decorar espacios que les hagan verse "diferentes", cuando en el fondo, existe es un interés homogeneizante por parte quienes proveen los modelos estéticos imperantes (Lipovetsky, 2003; Sibilia, 2008). Por supuesto, esto no aplica para todos los jóvenes.

\subsection{Jóvenes y emergencia de otro tipo de estéticas}

En este trabajo también se ha querido destacar que entre los jóvenes existen también posturas a contracorriente con respecto a las estéticas dominantes. Algunos de ellos manifestaron en los diferentes momentos de esta investigación, algunas posturas estéticas que se encuentran más allá del querer parecer algo, para reafirmase como sujetos que 
tienen la capacidad de interpretar el medio y reelaborar sus propias versiones de los criterios estéticos que han incorporado a su forma de presentarse a los demás a través de las fotos de perfil. He aquí alguna de las intervenciones más sobresalientes de este tipo de posturas a través de los tres instrumentos aplicados. Se irá comentando cada una de ellas: "Pues a veces creo que deben ser bellas y a veces no. Pues desde que me guste a mí, puede estar bien tenga o no tenga filtros" (hombre de 14 años. Fuente: sondeo exploratorio). Aparece la idea de que las fotos no tienen por qué ser bellas; es decir se da la posibilidad de pensar que ese espacio de perfil, puede expresar sentidos distintos y alternativos a querer destacar físicamente.

Otros jóvenes mencionaban que no necesariamente elaboraban sus fotos demasiado: "yo casi no me pongo accesorios en mis fotos de perfil, porque no me gusta. Prefiero una foto de forma casual"; "yo pienso que uno sin ningún accesorio es bello y además no se necesita algo para ser bello, si uno se considera más bello" (hombre de 14 años. Sondeo exploratorio). Lo que nos hace reflexionar acerca de que no en todos los casos la creatividad sería usada por todos los jóvenes en la elaboración de perfiles que traten de impactar a los demás. Adicional a ello, algunos de ellos muestran en sus fotos algunas posturas que intentan reflejar estados de ánimo reales o situacionales: "La mayoría de veces solo sonrío. Me gusta mucho mi sonrisa y significa que estoy segura de sí misma” "mujer de 14 año (sondeo exploratorio).

Entre algunos de los jóvenes se dan otras posibilidades de comprensión de lo estético, que se conectan con la expresión libre de cada uno, de aquello que representa su identidad, sin necesidad de querer visibilizarse o ganar los likes que a otros tanto les 
interesan: "La mayoría de fotos que yo tomo a mí me quedan bien, porque la belleza está en el interior de uno" (hombre de 17 años. Entrevista) De ahí que para estos jóvenes el uso de ropa, accesorios y posturas corresponda más con una necesidad del momento o el interés de expresar cómo se sintieron en una situación dada: "No uso accesorios a menos de que ya sea una necesidad como los lentes. Uso posturas si yo quiero representar cosas que estén sucediendo" (hombre de 16 años. Sondeo exploratorio).

De ahí que este tipo de jóvenes no estén demasiado preocupados por figurar o ser visibilizados por los demás para que los acepten: "Yo me arreglo y me visto no para que los demás opinen y si me critican no los escucho, porque a mí no me gusta opinar de las otras personas que, si están feos o si están lindos, no me gusta” (mujer de 14 años) Entrevista). Se aprecia una valoración más importante por aquello que el mismo sujeto pueda pensar o sentir frente a su propia imagen $\mathrm{y}$, por supuesto, aquellas fotos que publica: "Pues si les gusta bien, pues si no, me resbala, porque yo me peino para mí, me visto para mí, todo lo hago para mí. Me podría muy feliz por ellos me aceptan como soy, yo no le tengo que hacer arreglos a las fotos porque así soy yo" (mujer de 14 años. Entrevista). En oposición a la mayoría, este tipo de jóvenes centra su atención en los momentos vividos, en lo que los identifica y en las situaciones que les parecen significativas y que, por lo mismo, desean compartir. Así, dice uno de estos jóvenes cuando le preguntaba la investigadora si le parecía importante que le dieran likes a sus fotos: "Para mí eso no es tan importante, porque siempre que subo una foto, no es para satisfacer a los demás, siempre mirando entorno de lo que vivo y quiero" (mujer de 14 años. Entrevista). 
En las intervenciones de estos jóvenes, se puede interpretar una concepción de estética que se enfoca en la expresión de sí mismos y no, en modelos impuestos sobre lo que se debe considerar bello: "Para mí la estética en las fotos es mirarse y no mirar tus imperfecciones si no lo quieres mostrar a través de ellas, sin importar lo comenten y si les gusta (mujer de 17 años. Entrevista). Se opta en esta posición por una estética del sentido, de aquello que en verdad significa algo para los sujetos, como sus recuerdos, sus esperanzas, la forma en que quieren ser identificados y su propia sensibilidad: "Manillas: para verme identificada con la historia de estas manillas y por cuántas personas pasaron y que combinen con lo que uso y que signifiquen algo para mí” (mujer de 14 años. Entrevista)

Lo anterior nos lleva a pensar en que existen entre los jóvenes otras formas de concebir a la creatividad. De acuerdo a la representación social de personalización, la creatividad es utilizada en muchos casos para crear fotos de perfil muy elaboradas, con la intención de parecerse a ciertos modelos estéticos mediáticos. Sin embargo, no se debe desconocer que, ese ser creativo también se despliega hacia la producción juvenil de híbridos (Muñoz, 2010), en donde se mezclan elementos recogidos del medio, con otros que incluyen la expresión de sus formas de situarse como sujetos en el mundo.

De hecho, en este trabajo no se ha pretendido concebir a la juventud como una masa homogénea, sin capacidad de agencia. Se ha planteado es que, de acuerdo al contexto social, cultural, económico en el que se desenvuelven los jóvenes, se han ido generando una serie de representaciones sobre lo estético que dan cuenta de este contexto y de la interacción de los sujetos jóvenes en él. Sin desconocer que, dentro de cada una de esas 
representaciones, existen intersticios, fugas, hibridaciones, jóvenes que, quizá llevan en sí algunas particularidades de una representación social descrita, pero que también logran construir expresiones sobre sí mismos que escapan a las generalidades de cada representación, o realizan combinaciones entre sus ideas, sus propias sensibilidades y alguno de los modelos estéticos a los que se está expuesto. Hibridaciones, reinterpretaciones que se ejemplificaron con los datos obtenidos en cada instrumento con frases concretas, al igual que se hace en este apartado.

Sí se parte de la idea de que es importante tener identificadas, descritas y analizadas las representaciones más comunes frente a la estética que manejan los jóvenes, pero no con la intención de presentar una versión homogeneizada y homogeneizante de lo que significa ser joven hoy en día. Más bien de lo que se trata es de que, si se logra identificar y comprender los sentidos de esas representaciones, se puede abrir el camino para entender y, por qué no crear estrategias de comunicación que permitan que los jóvenes tengan los espacios suficientes para desarrollar sus propias versiones de lo que significa la estética como forma de expresión de sí.

Frente a este punto, los aportes de Feixa (1999) son sumamente valiosos porque nos instan a pensar que los jóvenes están todo el tiempo reelaborando los contenidos a los que están expuestos, imprimiendo su estilo a todas sus creaciones, las cuales serán mezcla de elementos a los que acceden a través de identidades generacionales que les proporcionan ciertas características, aspectos de género, clase y territorio (Feixa ,1999). A esto agregamos que el joven tiene a disposición gran cantidad de elementos culturales local y globales. Por lo cual aquello que elabora, por ejemplo, en las redes sociales, 
específicamente sus fotos de perfil, también son producto de esas hibridaciones de esos bricolges (Feixa, 1999) en los que se juegan sus concepciones acerca de la estética.

Desde Feixa (1999) y Muñoz (2010), la configuración de nuevas estéticas producto de subjetividades híbridas, se da sobre todo a partir de las culturas juveniles, las cuales entran en tensión constante con lo global, sin que ello signifique que las concepciones estéticas de los jóvenes se cristalicen en lo uno o en lo otro. Más bien se plantea que el joven sería un sujeto creativo, que tiene la capacidad de componer expresiones artísticas que den cuenta de procesos subjetivos, que interpreten la realidad y puedan proponer formas alternativas de comprenderla y vivenciarla (Feixa,1999;Muñoz 2010).

Feixa (1999) de hecho habla de una simbiosis entre el medio social y cultural de los jóvenes, con sus estilos individuales. Aspecto que pudimos observar en los datos recolectados, cuando por ejemplo los jóvenes sí decían obtener sus modelos de la televisión, Internet, pero que los mezclaban con aquello que les gustaba a ellos o con el tipo de ropa, accesorios y posturas que veían en sus familias y amigos más cercanos. De ahí que la forma en que se presentaban en sus fotos de perfil, respondían a mixturas conformadas a través de varias fuentes culturales, además de las marcas de su subjetividad como sujeto particular. Ejemplo de ello aparecía en las muestras cuando algunos jóvenes afirmaban que les gustaba hacer ciertas señas con las manos, con las que querían indicar que les gustaba la paz, pero además reinterpretaban esas señas en relación a sus propias interpretaciones de lo que esto significaba: "usualmente no suelo adoptar ninguna posición en mis fotos, pero suelo hacer mucho el signo de paz porque creo que demuestra confianza y orgullo" (hombre de 14 años. Sondeo exploratorio). El 
joven hace aquí una reinterpretación de un signo que, culturalmente, ha ido convirtiéndose en símbolo, pues contiene una carga emotiva que se comparte socialmente. Pero nótese cómo re elabora su sentido a partir del prisma de su subjetividad. Para muchos, ese símbolo no implicaría confianza u orgullo, pero de acuerdo a la historia personal, vivencias y elementos subjetivos del joven se re elabora el sentido del mismo y se le transforma en otra cosa. Se agrega este ejemplo, porque consideramos que es representativo de la forma en que el joven, como sujeto con capacidad de agencia, es capaz de elaborar nuevos sentidos a partir elementos que le son dados desde el contexto.

El joven se concibe entonces como un ser de naturaleza creativa, capaz de hacer bricolajes entre los estilos que encuentra en las industrias culturales, en los gustos estéticos dominantes en su generación, entre otras fuentes y las recrea a partir de su estilo individual, mostrando una imagen pública que es el resultado de esas mixturas (Feixa, 1999). En oposición a esta postura, estarían otras como las de Bauman (2007) y que también se tienen en cuenta en este estudio, en donde las imágenes de los sujetos en la sociedad de consumidores se elaboran, pero de acuerdo a los intereses del mercado, para obtener una imagen-mercancía que sea vendible (Bauman, 2007). En este estudio, y sobre todo después de haber tenido la experiencia en campo, se afirma que el fenómeno de la presentación de sí mismos a través de las fotos de perfil de los jóvenes no se puede entender en una escala de blanco o negro en relación con estas dos posiciones. Más bien, se considera que el joven sí utiliza esos modelos que emergen de los medios, de las industrias culturales, pero tampoco los recepciona pasivamente. Con ellos, es capaz de crear algo nuevo. Los reinterpreta y realiza un proceso de reelaboración, que le permite 
crear sus propios criterios con relación a qué es lo estético en espacios como Facebook. De ahí que, pese a haber identificado, descrito y analizado las principales representaciones sociales de los jóvenes en su mayoría acerca de la estética, en este apartado se aprovecha para analizar cómo esas representaciones no se pueden entender como estructuras rígidas. Sí permiten realizar una aproximación a la compresión de cómo están compuestas las concepciones de los jóvenes frente a la estética y cómo se manifiesta esto en la forma en que se presentan en sus fotos de perfil, focalizado eso sí, en los indicadores corporales que muestran, pero no permiten agotar la discusión acerca del tema, porque como hemos observado, no se presentan en todos los jóvenes de la misma manera.

De hecho, desde la postura de Jodelete (1984), las representaciones sociales son formas de conocimiento social que permiten dotar de significados a lo que nos rodea, lo que se hace a través del lenguaje, pero esos significados no son estáticos, están en una constante reelaboración en diálogo entre lo individual y lo social; son imágenes mentales que construyen realidades (Jodelete, 1984). De ahí que algunas de las representaciones sociales de los jóvenes y la reelaboración que hacen de lo que les viene de su cultura, sean constructoras de formas de ser y estar en el mundo. Por esta razón, es tan importante analizar qué construcciones mentales han elaborado y reelaborado los jóvenes sobre lo estético, pues estas a su vez, crean realidades. La idea sería que, en esa realidad concebida por los mismos jóvenes, ellos puedan reconocerse como sujetos capaces de agenciar procesos de cambio social que sean más incluyentes y respetuosos de la diferencia. En este orden de ideas, los jóvenes se conciben en este trabajo como activos productores de cultura y no solo como receptores pasivos de las industrias culturales 
(Feixa, 1999). Sin desconocer por supuesto el nivel de participación e influencia que tienen dichos medios en la configuración de representaciones sociales en los jóvenes, como se pudo observar a lo largo de este trabajo.

La concepción de lo estético en los jóvenes que se encontró en este estudio, específicamente después del trabajo de campo, se encuentra más ligada a lo que Feixa (1999) denomina creación estilística sincrética y multifacética, porque implica una visión del joven como un agente de cambio cultural, capaz de promover trasformaciones sociales importantes a partir de la reelaboración que hace de los contenidos que le rodean, a partir de su experiencia personal. De ahí lo sincrético, porque en ocasiones implica que, en sus creaciones, el joven realice una combinación de elementos que podrían parecer en un primer momento contradictorios, como por ejemplo sus gustos personales con los imperativos globalizados del gusto y la moda.

Un camino para lograr que el joven se convierta en un activo agente de trasformación cultural es teorizado por Muñoz (2010) en conexión con la creación artística. Para el autor, el joven no puede seguir siendo catalogado como un ente pasivo de recepción de los modelos culturales de los medios y del mundo adulto, sin reconocerles su activa participación en la construcción de realidad y de formas alternativas de comprenderla (Muñoz, 2010). Desde esta postura se propone una interpretación de lo estético en relación con los jóvenes, que trascienda los límites del arte y se instale más en una creación desde sus experiencias personales. El joven, desde sí mismo, tiene la capacidad de reelaborar la realidad a partir de una interpretación de lo estético que incluye un proceso activo de auto creación: 
La dimensión estética, es decir, la dimensión de creación -de sí mismo, de otros marcos de referencia, de nuevas subjetividades colectivas y de otras formas artísticas-, permite ver a las culturas juveniles, y a las más creativas entre ellas, como descomunales potencias de transformación, destrucción y creación de otra cosa (Muñoz, 2010, p.5)

Nuevamente aparece en el panorama la dimensión creativa del joven, a quien se le reconoce la capacidad de reelaborar aquello que le viene dado desde la cultura, los medios, para crear sus propias versiones acerca de lo que le rodea. En el caso que nos compete, diremos que el joven tiene toda la capacidad de agencia para elaborar formas de presentarse a sí mismo a través de su imagen de perfil, que incluya un conocimiento (Muñoz, 2010) de sí mismo, de su sus propias interpretaciones y criterios de lo que considera estético. 


\section{Conclusiones}

En esta investigación se buscó aproximarse a una comprensión de los sentidos de las representaciones sociales de los jóvenes acerca de la estética, manifestadas a partir de los significados que dan a los indicadores corporales que muestran en sus fotos de perfil en Facebook. Para lograrlo, en primer lugar, se identificaron los elementos que constituían a esas representaciones, para así identificar las representaciones mismas (objetivo específico número 1). Después de ello, se hizo una descripción de cada una de las representaciones halladas (objetivo número 2). Finalmente, se llevó a cabo un análisis de esas representaciones, atendiendo a las peculiaridades culturales de los jóvenes participantes, para llegar finalmente a abordar el objetivo central que fue acercarse a la comprensión de los sentidos que tienen esas representaciones, focalizándonos en cada uno de los objetivos, en los significados que los jóvenes dan a los indicadores corporales que muestran en sus fotos de perfil, lo cual se indagó a partir de los tres instrumentos que se utilizaron, a saber: cuestionario del sondeo exploratorio, cuadro de elementos significativos, mapa semántico y a través de la aplicación y análisis de la entrevista semiestructurada.

La primera representación social identificada y descrita fue la de apariencia de felicidad. Su núcleo es la necesidad de los jóvenes de mostrar a los demás que se tienen actitudes alegres a partir de: realizar poses llamativas, indicar que se tiene capacidad adquisitiva y creatividad para elaborar fotos de perfil que gusten a los demás.

La pose más importante que utilizan los jóvenes para parecer felices es la sonrisa. Esta, a su vez, se divide entre sonrisa real y fingida. La primera la usan para "verse 
mejor" en las fotos, mientras la segunda representa algunos momentos felices y realmente significativos para el joven, pero su uso es menos común que el de la sonrisa fingida.

Por su parte, la capacidad adquisitiva se relaciona con mostrar a los demás que se tienen los recursos materiales para estar a la moda y/ o que se cuenta con la habilidad para elaborar fotos de perfil con variedad de accesorios virtuales como: emojis, fondos, filtros, entre otros, con el fin de embellecer dichas fotos.

De ahí que el último elemento constitutivo de esta representación de apariencia de felicidad sea la creatividad. A partir de esta, el joven es capaz de elaborar fotos de perfil que luzcan luminosas, coloridas, alegres a partir del dominio técnico y tecnológico de las estrategias de las que dispone para lograr este fin. No obstante, a partir de los datos recolectados, se pudo establecer que no todos los jóvenes conciben de la misma manera la relación entre felicidad-verse atractivo. Algunos mencionaban que se mostraban a sí mismos en situaciones de alegría, porque deseaban compartir con los demás algunos momentos que les resultaran significativos.

La segunda representación social identificada y descrita fue la de apariencia de belleza. Su núcleo es la tendencia que se tiene a perseguir la perfección en la apariencia deseada. Para conseguirlo, se busca llamar la atención, resaltar los atributos físicos que se consideran bellos, elaborando fotos de perfil que den cuenta de esos ideales de belleza.

Se encontró que muchas de las mujeres de la muestra, tienen una tendencia mayor que los hombres para llamar la atención a partir de demostrar: sensualidad, delicadeza, 
picardía y ternura, lo que se logra a partir de unas poses planeadas de antemano. Verse sensual, implica que sus fotos resalten su cuerpo o una parte específica de este. Por lo general, se valora como bella una silueta esbelta, delgada, sin imperfecciones de ningún tipo, de acuerdo a los cánones de belleza generalizados que se manejan.

En el caso de los hombres, la apariencia deseada y con la que buscan llamar la atención (aunque un tanto menos que las mujeres), es mostrando unas poses que denotan seguridad, seriedad y sensualidad;esta última conectada con la rudeza en varias ocasiones.

De todas formas, se concluye que, en ambos géneros, en su mayoría, se busca resaltar los atributos físicos que se valoran como deseables. Para lo que se recurre a enfocar todo el cuerpo o una parte de este, usar ropa que esté de moda o sea llamativa o utilizando accesorios virtuales y no virtuales, que alejen a las fotos de lo simple, que es sinónimo de feo o poco atractivo. Sin embargo, algunos de los jóvenes señalaban que creaban ciertas fotos de perfil con la intención de proyectar a los demás aquello que los identificaba, sin tener ningún interés en llamar la atención o visibilizarse de acuerdo a unos atributos físicos normalizados.

La tercera representación social identificada y descrita fue la del reconocimiento. Su núcleo es la tendencia de muchos jóvenes a querer que sus fotos sean visibles. Lo serán, si logran llamar la atención. Al hacerlo, se busca la aceptación de los otros, especialmente la de los pares. Para lograrlo, el joven busca resaltar a partir del uso de ropa, accesorios (virtuales y no virtuales) y poses. A su vez, el ser aceptado se relaciona con felicidad, aquella que da el ser reconocido y la popularidad que ello conlleva, lo que 
permitiría al joven relacionarse más con sus pares dentro y fuera de Facebook. Esta representación es más preponderante en las mujeres, aunque apareció en ambos géneros. De todas maneras, una parte de los jóvenes, aunque menor, manifestó no mostrarse demasiado preocupada por la opinión de los demás. Contrario a ello, afirmaban que el principal interés que tenían al publicar sus fotos, era que fueran del agrado de sí mismos, porque representaban expresiones de su personalidad y vivencias que deseaban compartir, sin el ánimo de obtener con ello la aceptación de los demás.

La cuarta representación identificada y descrita fue la de personalización. Su núcleo es la tendencia de los jóvenes a verse diferentes. Lo que se logra siempre y cuando se pueda señalar que las fotos que se publican tienen un estilo propio. Para alcanzarlo, el joven mostrará que está a la moda, no solo en el uso de ropa, accesorios (virtuales y no virtuales), sino en las poses más usadas en el momento. A su vez, debe evidenciar que sus fotos son elaboradas a partir del uso de las técnicas y tecnologías de las que se dispone para embellecerlas. Adicional a ello, el joven parecerá tener un estilo propio, si corrobora que tiene personalidad. Lo que se logra si se ve interesante en las fotos; es decir si estas son únicas. Además, tener personalidad es frecuentemente asociado con tener unos gustos propios que reflejen que se es independiente para elegir por sí mismo cómo presentar su perfil a los demás, para sentirse cómodo consigo mismo, pero sobre todo para gustar a los demás. Esta representación también es más fuerte en las mujeres, pero aparece en ambos géneros. Pero, nuevamente, algunos de los jóvenes de la muestra manifestaron algunas opiniones distintas frente a la diferenciación. Afirmaban que personalizaban sus fotos de perfil para expresarse libremente, no necesariamente para verse más atractivos en ellas, ni gustar a otros, debido a que consideraban que la estética 
tenía más relación con la expresión de su singularidad, sentimientos y emociones que deseaban transmitir a través de esas imágenes.

También se pudo concluir que las cuatro representaciones sociales identificadas y descritas están interconectadas. Las cuatro, forman un relato que se conecta con los ideales estéticos compartidos social y culturalmente y que, en buena medida, coinciden con los cánones de belleza imperantes, salvo en algunos casos, como se describió antes.

Después de desarrollar los tres objetivos específicos, se abordó el objetivo central de este trabajo. Se analizaron los sentidos que tienen las representaciones sociales acerca de la estética a partir de los significados que dan los jóvenes a los indicadores corporales que muestran en sus fotos de perfil

Algunas de esas construcciones simbólicas tienen que ver con que para muchos de los jóvenes parece ser más importante parecer feliz, que serlo o tener realmente actitudes de alegría. Aparentar felicidad, se conectaría entonces con verse bello en las fotos de perfil. Se analizó cómo ese bienestar y actitudes alegres se corresponden, usualmente, con las creencias culturales y popularizadas acerca de lo que implica mostrarse feliz, por ejemplo: ser atractivo, reconocido, tener capacidad adquisitiva y dominar las técnicas y tecnologías de la corporeidad para embellecer las fotos que se publican. No obstante, esto no ocurre ni en todos los jóvenes, ni en todas las ocasiones. Perfectamente uno de ellos podía describir una foto en donde estuviera, según él o ella decía, fingiendo una sonrisa, y en otra agregar que estaba realmente feliz en ese momento y quería compartirlo con otros. 
Por otro lado, ser bello parece ser hoy en día menos relevante que parecerlo. Lo que se ve reflejado en la tendencia de la mayoría de los jóvenes por embellecer sus fotos de perfil, utilizando para ello todas las estrategias que tenga a la mano. Se da gran relevancia al signo-foto en sí mismo y al poder de este para llamar la atención, relatar atributos físicos, sin necesidad de que este atractivo se corresponda necesariamente con lo que se es realmente. Allí, en varias ocasiones, los modelos mediáticos de belleza están conectados con los ideales estéticos que manejan los jóvenes y que comparten en buena medida con la cultura y el contexto social al que pertenecen. De ahí que muchas de las fotos de perfil se elaboren teniendo presente algunos de los estándares de perfección normalizados. Lo que no implica que los jóvenes asuman sin más dichos modelos. Más bien ocurre que se realizan ciertas hibridaciones, bricolajes, en donde el estilo personal, es combinado con aquellos elementos locales y globales (Feixa,1999) que encuentra el joven para elaborar sus fotos en su contexto.

Para buena parte de los participantes, existir es sinónimo de ser visible, por lo menos desde entornos virtuales como Facebook. Ser reconocido por los demás a partir del atractivo de sus fotos de perfil, se convierte en un indicador importante porque le permite socializar más, tanto dentro como fuera de la red social. Buena parte de los jóvenes de la muestra, buscan ser aceptados socialmente, por eso elaboran fotos que incluyan ciertos aspectos de belleza y perfección social culturalmente normalizados. Es comúnmente valorado el nivel de aceptación e impacto positivo que logren los jóvenes en los demás, por lo que se elaboran fotos de perfil que cumplan con el objetivo de gustar a los otros. Las fotos se convierten en algunos casos, en signos de consumo que se valorizan, en tanto logren la aprobación de los pares de los jóvenes. No obstante, esto no ocurre ni en 
todas las ocasiones, ni en todos los jóvenes. Algunos afirmaban que, con ciertas fotos, tenían la intención de resaltar o gustar a los demás, pero en otras y que también incluían en sus perfiles, querían compartir un momento agradable o expresar algo relacionado con sus gustos y personalidad, o, simplemente, reflejar algún estado emocional que tuvieran en el instante.

Para buena parte de los jóvenes, verse bello se conecta también hoy en día con verse diferente; es decir, resaltar de los demás. Existe la creencia en varios de ellos de que, para lograrlo, elementos como la moda o las nuevas tecnologías que ayudan a transformar la imagen personal, les ayudarían a cumplir con este propósito. Lo paradójico tiene que ver con las tendencias usualmente homogeneizantes que conllevan dichos factores.

Verse único, interesante, poseer un estilo propio se ha convertido en un imperativo en las redes sociales. Muchos jóvenes tratan de demostrar que tienen la independencia necesaria para transformar su imagen personal, de acuerdo a sus gustos personales. No obstante, el discurso de personalización que maneja el mercado, lleva implícitos unos intereses reguladores que intentan delimitar las opciones que tiene el joven para crear la imagen que luego publica. Sin embargo, de acuerdo a los resultados de esta investigación, los jóvenes juegan con esas aplicaciones, usan las posibilidades que les brinda, pero le imprimen sus estilos e intereses personales para crear versiones de su imagen que les haga sentir identificados. De lo contrario, los jóvenes serían simples marionetas de un sistema estético frente al que no podrían aportar o transformar nada. En este lugar se afirma que esto no es así, aunque sí se evidencia que esa tendencia a 
proyectar los ideales estéticos del mercado, se encuentra marcada en algunos de ellos, más que en otros.

También se puede concluir que existen ciertos jóvenes que manifiestan otras concepciones de estética que no están limitadas a asociarla con la belleza o el atractivo que puedan mostrar en sus fotos de perfil, a través de ciertos indicadores corporales como: accesorios, ropa, gestos, etc., más bien esta es interpretada como la expresión y sensibilidad personal frente a la vida, a lo que les pasa y los identifica.

En estos casos, la belleza dejaba de conectarse tanto con el parecer bello en las fotos, para trasladarse al plano de ser bello e interesante desde sí mismos. Dichos jóvenes, tendían a relacionar a la estética en sus fotos de perfil como al recuento de unas experiencias de vida significativas para ellos. Adicional a ello, algunos expresaban que utilizaban algunas de las herramientas que proporcionaba Internet, para personalizar su propia imagen, pero las usaban para crear otras versiones de sí mismos que, no necesariamente tenían que coincidir con los ideales de belleza culturalmente aceptados. Es decir, se apelaba a la creatividad, pero con el objetivo de crear sus propias alternativas frente a lo que consideraban agradable.

Estas ideas, crearían unas interferencias o intersticios en los relatos que se han venido normalizando acerca de lo que debe considerarse estético desde las hegemonías, lo que demuestra que los jóvenes pueden resignificar los relatos que se han venido aceptando social y culturalmente sobre lo estético, para hacerlos parte de un sistema de consumo que interesa perpetuar. Lo anterior, es posible en la medida en que los jóvenes no son concebidos en este estudio como entes pasivos. Contrario a ello, se piensa que ellos 
tienen las herramientas necesarias para plantearse otras formas de comprender lo estético, que redunden en la construcción de otros relatos posibles sobre los que basar sus representaciones, que no necesariamente tienen que ser los promulgados por las industrias culturales y las lógicas consumistas.

Se concluye, por tanto, que los jóvenes tienen toda la capacidad de asumir el reto de crear otras posibilidades de interpretación frente a las narrativas imperantes, que se sustenten en interpretaciones diferentes de lo que significa una experiencia estética. Para hacerlo, se puede recurrir, como bien lo expone Muñoz (2010), al arte y a concebir a la vida como una obra de arte, en donde la creatividad esté al servicio de la responsabilidad y el cambio social.

De hecho, ya en las reelaboraciones, bricolajes e hibridaciones de estilo que manejan los jóvenes (Feixa,1999) en sus fotos de perfil, se evidencia que no son simples agentes pasivos de un sistema que los usa para lograr sus objetivos, aunque se sospeche que ese sea uno de los objetivos de los mercados. Sin embargo, tampoco se puede desconocer que, en una gran cantidad de jóvenes, esas representaciones sociales acerca de la estética necesitan de un proceso de deconstrucción, para abrir otras posibilidades de sentido que los lleve a fortalecerse como constructores de otro tipo de realidades.

La idea sería, que, a través de la deconstrucción de ciertas representaciones sociales imperantes en la mayoría de los jóvenes hasta cierto punto, se logre lo que proponía Muñoz (2010), que era encontrar otros tipos de existencia, que se fortalezcan desde el autocuidado y la expresión estética, entendida esta como una forma de sensibilidad tendiente a proponer alternativas de sociedades más incluyentes. 
Lo que se aporta al respecto en este trabajo, es que esas representaciones sobre la estética que se lograron identificar, caracterizar y hasta cierto punto analizar, empiecen a ser deconstruidas desde el sentido de deconstrucción del que habla Derrida (1988), para quien deconstruir es empezar a cuestionar desde el fondo ciertas amalgamas de sentido que se han ido fosilizando en las teorías, los programas y, en general, en todo el sistema de pensamiento que concebimos como normal, para escapar de una lectura del mundo que se ofrece desde las industrias culturales, los discursos que manejan los mercados y que nos presentan sus versiones de lo que es o no estético.

Deconstruir las representaciones sociales sobre lo estético que tienen muchos jóvenes, implicaría resignificarlas, para ponerlas a jugar a favor del cambio social. Se propone que, si se lograra deconstruir por ejemplo la representación de apariencia de felicidad, enfocándola hacia la expresión de la alegría a través de una concepción estética que se conecte con la importancia de disfrutar la vida, se estaría creando otro sentido para esa representación, entre muchos otros posibles. Al deconstruir la representación de apariencia de belleza, se podría reforzar otros ideales estéticos que le apunten menos al simple atractivo físico y se enfoquen más en la experiencia, en la creación y fortalecimiento de subjetividades que busquen trasformaciones sociales positivas. Al deconstruir la representación de personalización, se podría optar por poner esa creatividad que tienen los jóvenes al servicio de la construcción de otras posibilidades de existencia, menos enfocadas hacia un desarrollo puramente económico, para visibilizar otras que se enlacen con el bien común y el desarrollo personal de cada uno, pero en consonancia con un bienestar común. Al deconstruir la representación de reconocimiento, se podría aprovechar la visibilidad que brindan las actuales redes 
sociales, para que los jóvenes puedan proyectar sus ideas, sus formas particulares de expresarse. Así, en vez de buscar la pura aprobación social y popularidad, se optaría por viralizar posiciones alternativas, con respecto a cómo funcionan los sistemas que actualmente nos gobiernan, entre ellos, el económico.

Todo lo anterior se puede llevar a la práctica, pero son los mismos jóvenes quienes tienen que trabajar arduamente por visibilizarse como sujetos empoderados, capaces de agenciar posibilidades alternativas de ordenamientos sociales más incluyentes. Para ello, cuentan con gran cantidad de herramientas que brindan lo enfoques comunicativos que se centran en lo comunitario, en el desarrollo y cambio social desde las comunidades mismas. De ahí que este trabajo de investigación aporte una reflexión que se inscribe en los intereses de la Maestría en Comunicación, Desarrollo y Cambio Social, porque se propone que un primer paso para empezar a crear alternativas de ordenamientos sociales, es conocer cómo están estructuradas las construcciones simbólicas de las personas, en este caso las de los jóvenes, para después crear alternativas de comunicación alternativas y emergentes, para generar transformaciones positivas en las comunidades y en la participación de estas en la construcción de mundos de vida.

Ahora bien, si tenemos presente que los jóvenes en la actualidad tienen una especial conexión los medios interactivos, especialmente aquellos que se desarrollan por internet, (Urresti, 2008; Pisticelli ,2009; Morduchowicz 2012; Reguillo,2007) y los utilizan frecuentemente para crear sus propias reelaboraciones con respecto a la información globalizada que reciben de los medios (Reguillo, 2009), se considera que, a partir de esas posibilidades creativas, se pueden liderar procesos de resistencias cada vez más 
organizados, en donde los jóvenes puedan explotar todas las opciones que brindan los enfoques alternativos de la comunicación, que optan por la exploración de estrategias más comunitarias y que apuntan a la creación de canales de comunicación más horizontales y respetuosos de la diferencia, así como menos enfocados en el desarrollo puramente económico de las sociedades.

En este proceso de investigación, se destaca que se llegó a un nivel de comprensión importante con relación a la conformación, estructura y sentidos acerca de las representaciones sociales de la estética en los jóvenes de la muestra. No obstante, aún existe un largo camino investigativo por recorrer frente a las temáticas que vinculan a la juventud con los contextos virtuales, específicamente en relación a representaciones sociales y estética. Adicional a ello, aunque la muestra recogida con que se trabajó fue significativa, no se pretende que los resultados puedan ser aplicados indistintamente a todos los contextos sociales y culturales que involucran redes sociales y jóvenes, dadas las particularidades de los participantes con quienes se trabajó. Sin embargo, sí se procura haber aportado elementos de análisis, que amplíen el panorama acerca de cómo se están manifestando las representaciones sociales de la estética en los jóvenes, y las relaciones que existen entre estas y los actuales poderes y estrategias de normalización propias de la sociedad contemporánea. 


\section{Recomendaciones}

Para próximas investigaciones cuyo tema esté relacionado con el que se trabajó en esta, se podría profundizar más en la conexión que existen entre algunos consumos culturales específicos, tales como la televisión, Internet, la música con las representaciones que se tengan acerca de la estética. Lo que podría enriquecer el análisis y que no se profundizó en este estudio, porque la amplitud de lo que implicaría da para otro trabajo investigativo.

También se podría realizar una investigación cuyo eje central sea la conexión entre representaciones sociales y la perspectiva de género. En este trabajo, la diferenciación por género apareció como parte de los hallazgos, pero no se focalizó suficientemente en la medida en que no estaba contemplado en lo que se propuso desde el principio.

En otros trabajos en relación a la estética se podría ampliar un poco más la muestra, con el fin de que salgan a flote otros elementos de análisis que no se alcanzaron a captar en este estudio.

Otra de las posibilidades investigativas que se podrían explorar con respecto a la estética y las representaciones sociales de los jóvenes en redes sociales, sería escoger como corpus las fotos mismas y realizar un proceso de interpretación semiótico con estas. Lo que permitiría hacer un contraste interesante con respecto a este estudio, en donde el corpus seleccionado fue aquello que los jóvenes expresaban por escrito acerca de aquellos aspectos que consideraban importantes en relación a la estética en sus fotos 
de perfil. Se podrían comparar los resultados y, seguramente, aportar nuevas perspectivas para analizar fenómenos sociales de este tipo. 


\section{Referencias bibliográficas}

Abric, J (1994). Prácticas y representaciones. Francia: Coyoacán Ediciones.

Adorno, T. (1975). Dialéctica negativa. Madrid: Taurus

Adorno, T. (2004). Teoría estética. Madrid: Akal

Aguirre, J. (2011) Introducción al Análisis de Redes Sociales. Buenos Aires:

Albert, M (2006). La investigación educativa: claves teóricas. España: McGraw Hill

Alexander, J. (2000). Sociología cultural. Formas de clasificación en las sociedades complejas. México: Antropos Ed.

Almansa, A., Fonseca, O., y Castillo, A. (2013). Redes sociales y jóvenes. Uso de Facebook en la juventud colombiana y española. Comunicar, (40), 127-135. Recuperado de http://www.redalyc.org/articulo.oa?id=15825476014

Baricco, A. (2008). Los bárbaros. Ensayos sobre mutación. Barcelona: Anagrama.

Barthes, R. (1980). La cámara lúcida. Notas sobre la fotografía. Barcelona: Paidós Ibérica

Basile, D. y Linne, J. (2014). Performances de autopresentación a través de fotografías digitales. El caso de los adolescentes de los sectores populares en Facebook, (35), 209-217 Recuperado

de http://www.scielo.cl/scielo.php?script=sci_arttext\&pid=S0719367X20140002000 14

Baudrillard, J. (1974). La sociedad de consumo. Sus mitos, sus estructuras. España: Plaza \& Janes

Bauman, Z. (2007). Vida de consumo. México: Fondo de Cultura Económica 
Benjamin, W. (2015). Estética de la imagen: fotografía, cine y pintura. Buenos Aires: La marca editora

Bonacci, J. (2013). Sujetos, miradas, prácticas y discursos. Segundo encuentro sobre juventud, Medios e Industrias Culturales. Argentina: Ed. de la Universidad Nacional de Tucumán (UNT)

Bourdieu, P. (1988). “El sentido de la distinción” España: Editorial Taurus.

Canal Encuentro [Adrianarubiano1984@gmail.com]. (2012 noviembre 13). Mentira la verdad: la belleza. [Video]. Recuperado de https: //www.youtube.com/watch? $\mathrm{v}=550$ naz $8 \mathrm{Vak}$

Chaparro, H., Echeverry, S., y Arévalo, J. (2014). Desde el muro: una mirada a los discursos proyectados por el cuerpo en Facebook. Educación Física Y Ciencia, 16(1). Recuperado de http://www.efyc.fahce.unlp.edu.ar/article/view/EFyCv16n01a03

Darley, A. (2002). Cultura visual digital. Espectáculo y nuevos géneros en los medios de comunicación. Barcelona: Paidós Ibérica

Debray, R. (1994). Vida y muerte de la imagen. Barcelona: Paidós Ed.

Derrida, J. (1998). De la gramatología. Ciudad de México: Siglo XXI Editores.

Deleuze, G. (1999). Conversaciones. Valencia: Pre-textos.

Dillon, A. (2013). Miradas de adolescentes argentinos sobre la intimidad en Facebook. Anàlisi: cuadernos de comunicación i cultura, (49), 15-28. Disponible en: http://analisi.cat/article/view/n49-dillon

Dilthey, W. (1997). Hermenéutica, filosofía, cosmovisión. Barcelona: Ediciones, 62. Documentos de Trabajo, 82, Centro Interdisciplinario para el Estudio de Políticas Públicas, diciembre. 
Dugarte, A. (2006). Repensar en la investigación educativa de la nueva era. (Ponencia presentada en la III Jornada de Investigación Humanística y Educativa de la Facultad de Ciencias de la Educación). Revista Ciencias de la Educación, 1(27), 99-108.

Feixa, C. (1999) De jóvenes, bandas y tribus. Antropología de la juventud. Barcelona: Editorial Ariel.

Fernández, A, Zelich C, y Monter, J. (Comp.), (2004). La certeza vulnerable: cuerpo y fotografía en el siglo XXI. Barcelona: Gustavo Gilli Ediciones.

Gadamer, H. (2007). Verdad y método. Salamanca: Sígueme S.A.U Ediciones

Goffman, I. (1970). El Ritual de la Interacción. Buenos Aires: Amorrortu

Gumusio, A. (2004). Investigación y desarrollo,12(1),2-23. Recuperado de http://revistas.javeriana.edu.co/index.php/signoypensamiento/article/viewFile/245 $4 / 1728$

Gurevich, A. (2016). "El tiempo todo en Facebook". Aposta. Revista de Ciencias Sociales, 69, 217-238, http://apostadigital.com/revistav3/hemeroteca/gurevich.pdf

Gutiérrez, A. (2005). Virtualidad, alétheia, crítica. La esencia del arte en la estética contemporánea. España: Mileto ediciones.

Heidegger, M. (1958). Arte y poesía. México: Fondo de Cultura Económica

Hernández, R., Fernández, C., \& Baptista, M. del P. (2010). Metodología de la investigación. (J. M. Chacón, Ed.) (Quinta). México: Hill, Mc Graw.

Lipovetsky, G. (2003). La era del vacío. Barcelona: Anagrama.

López, R. (2010). La reina de las redes sociales. Revista Mexicana de Comunicación, (123), 12-19 https://issuu.com/mexcomunicacion/docs/rmc_123_facebook/7 
Manovich, L. (2005). El lenguaje de los nuevos medios de comunicación. La imagen en la era digital. Barcelona: Paidós Ibérica

Margulis, M. (Ed.) (1996). La juventud es más que una palabra: ensayos sobre cultura y juventud. Argentina: Biblos Editorial.

Martínez, P. C. (2006). El método de estudio de caso: Estrategia metodológica de la investigación científica. Pensamiento y gestión: revista de la División de Ciencias Administrativas de la Universidad del Norte, (20), 165-193. http://doi.org/10.1055/s-0029-1217568

Merleau Ponty, M. (1993). Fenomenología de la percepción. Madrid: Planeta

Morduchowicz, R. (2012). Los adolescentes y las redes sociales. La construcción de la identidad juvenil en Internet. Argentina: Fondo de cultura económica

Moscovici, S. (1979). El psicoanálisis, su imagen y su público. Buenos Aires: Huemul S.A

Muñoz, G. (2010). De las culturas juveniles a las ciberculturas del siglo XX. IDEP, (18), 21-32. Recuperado de: http://revistas.idep.edu.co/index.php/educacion-yciudad/article/view/166

Muñiz, E. (2014). Pensar el cuerpo de las mujeres: cuerpo, belleza y feminidad. Una necesaria mirada feminista. (29), 415-432. Recuperado de http://dx.doi.org/10.1590/S0102-69922014000200006.

Muñoz, G. (2010). De las culturas juveniles a las ciberculturas del siglo XX. IDEP, (18), 21-32. Recuperado de: http://revistas.idep.edu.co/index.php/educacion-yciudad/article/view/166

Muñoz, G. (2011). Jóvenes, culturas y poderes. Colombia: Siglo del hombre Editores.

Ortega y Gasset, J. (1992). La deshumanización del arte e ideas sobre la novela: Velázquez, Goya. México: Porrúa 
Pisticelli, A. (2009). Nativos digitales: dieta cognitiva, inteligencia colectiva y arquitecturas de la participación. Buenos Aires: Santillana.

Portillo, J. (2016). Planos de realidad, identidad virtual y discurso en las redes sociales. Revista de Lingüística, Filosofía y Literatura, (26), 51-63, http://www.scielo.cl/scielo.php?script=sci_arttext\&pid=S071932622016000100004

Protecciononline Py [Adrianarubiano1984@gmail.com]. (2014 junio 27). El autoengaño de una vida falsa. [Video]. Recuperado de: https://www.youtube.com/watch?v=LiEYYe_fWrU

Reguillo, R. (2007). Emergencia de culturas juveniles. Estrategias del desencanto. Colombia: Grupo Editorial Norma.

Rico, A. (1998). Las fronteras del cuerpo. Crítica de la corporeidad. Quito: Abya-Yala

Ricoeur, P. (2001). Del texto a la acción: ensayos sobre hermenéutica II. Buenos Aires: Fondo de Cultura de Argentina

Rubio, Á. (2010). Generación digital: patrones de consumo de Internet, cultura juvenil y cambio social. Revista de Estudios de Juventud, [online] (88), pp.201221.Recuperado de: https://dialnet.unirioja.es/servlet/articulo? codigo=3254569

Secretaría General de la Alcaldía Mayor de Bogotá D.C. (1995). Plan de Desarrollo Económico Social y de Obras Públicas para Santa Fe de Bogotá, D.C., 1995 1998 - Formar Ciudad. Recuperado a partir de http://www.alcaldiabogota.gov.co/sisjur/normas/Norma1.jsp?i=2393

Servaes, J. (2000). Publicaciones del Departamento de Ciencias de la Comunicación y del Centro de Investigaciones en Comunicación (CICOM), año 8 (10), 1-19. Recuperado de http://augusta.uao.edu.co/moodle/file.php/3325/SEMANA_03./Tres_paradigmas _dos_modelos._Jan_Servaes.LECTURA.pdf 
Sibilia, P. (2008). La intimidad como espectáculo. Buenos Aires: Fondo de Cultura Económica. Torres, M. \& Iglesias, M. (2011). Facebook: interacción juvenil en el espacio virtual. Ser visible, estar en el muro. Question. Question, [S.1.], (1), 1-9, Disponible en: http://perio.unlp.edu.ar/ojs/index.php/question/article/view/571/873

Toro, I y Parra, D (2010). Fundamentos epistemológicos de la investigación y la metodología de la investigación cualitativa y cuantitativa. Bogotá: Fondo Editorial Universidad EAFIT.

Urresti, M. (2008). Ciberculturas juveniles: los jóvenes, sus prácticas y sus representaciones en la era de Internet. Buenos Aires: La crujía Ediciones.

Villi, M. (2010). Visual mobile communication. Camera phone photo messages as ritual communication and mediated presence. Finland: Aalto University, https://shop.aalto.fi/media/attachments/43460/Villi.pdf

Vigarello, G (2005). Historia de la belleza: el cuerpo y el arte de embellecer desde el Renacimiento hasta nuestros días. Buenos Aires: Nueva Visión.

Wooglar, S (Ed.) (2005) ¿Sociedad virtual? Tecnología, “Cibérbole”, realidad. Capítulo: Cinco reglas de la virtualidad. Barcelona: UOC Ed.

Yin, R (1984). Case Study Research: Design and Methods, Applied social research Methods. London: Sage Publications. 


\section{ANEXOS}

\subsection{A. Anexo: Preguntas-respuestas sondeo exploratorio}

\begin{tabular}{|l|l|l|}
\hline Fecha de realización: & Lugar : salón 107 & Aula del Colegio Fernando González Ochoa \\
\hline Docente Investigador (DI): Adriana Rubiano Rubiano & \\
\hline Fecha y hora: 17 de julio de 2017. 9:15 Am & $\begin{array}{l}\text { 1. Identificar las representaciones sociales de la estética que tienen los } \\
\text { jóvenes (entre los 14 y 17 años, de grado octavo de la jornada mañana y } \\
\text { pertenecientes al colegio Fernando González Ochoa de la localidad de Usme) } \\
\text { manifestadas a partir los significados que dan a los indicadores corporales que } \\
\text { muestran en sus fotos de perfil en Facebook. }\end{array}$ \\
\hline Participantes : & $\begin{array}{l}\text { 30 jóvenes estudiantes del curso 802 JM. 15 hombres y 15 mujeres. } \\
\text { Caracterización del grupo: }\end{array}$ & $\begin{array}{l}\text { Este grupo de jóvenes se caracteriza por incluir personas que van de los 14 a } \\
\text { los } 17 \text { años. Son un grupo que en ocasiones tiene dificultades para prestar } \\
\text { atención (tener en cuenta que la investigadora es docente de los mismos). Sin } \\
\text { embargo, son muy colaboradores y asumen con buena disposición participar } \\
\text { en actividades que se salgan de la cotidianidad escolar. }\end{array}$ \\
\hline
\end{tabular}

\section{Descripción de la actividad:}

Después de haber realizado una lluvia de ideas para identificar los conceptos con los cuales los jóvenes de la muestra identifican a la estética en relación con las fotos de perfil en Facebook, cada joven contestaba cinco preguntas que intentaban recabar sobre el tipo de representaciones sociales que tienen sobre la estética en sus fotos de perfil en Facebook, específicamente focalizándonos en los 
accesorios, ropa, posturas corporales, gestos que muestran en ellas. Cada estudiante tenía un formato igual al usado para presentar los resultados, pero adaptado para una respuesta por pregunta.

\section{Preguntas sondeo exploratorio}

\begin{tabular}{|c|c|c|c|c|c|}
\hline Joven & $\begin{array}{c}\text { Pregunta \#1 } \\
\text { ¿Qué entiendes por } \\
\text { estética, en relación con } \\
\text { las fotos de perfil que } \\
\text { publicas en Facebook?; } \\
\text { ¿Crees que tus fotos de } \\
\text { perfil deben ser estéticas } \\
\text { si/no y por qué? }\end{array}$ & $\begin{array}{c}\text { Pregunta \#2 } \\
\text { ¿Qué aspectos estéticos o no } \\
\text { estéticos tienes en cuenta } \\
\text { cuando eliges una foto de } \\
\text { perfil para tu cuenta en } \\
\text { Facebook? }\end{array}$ & $\begin{array}{c}\text { Pregunta \#3 } \\
\text { ¿Qué tipo de ropa, } \\
\text { accesorios, posturas } \\
\text { corporales, utilizas en tus } \\
\text { fotos de perfil? Explica tu } \\
\text { respuesta. Si no utilizas } \\
\text { ninguno de los anteriores } \\
\text { elementos o sólo algunos, } \\
\text { menciónalo. }\end{array}$ & $\begin{array}{l}\text { Pregunta \#4 } \\
\text { ¿Cómo ha sido tu } \\
\text { experiencia personal con } \\
\text { las fotos de perfil en } \\
\text { Facebook, en relación con } \\
\text { la ropa, accesorios y } \\
\text { posturas corporales que } \\
\text { utilices en ellas? Si no } \\
\text { utilizas ninguno de los } \\
\text { anteriores elementos o solo } \\
\text { algunos, menciona cuáles } \\
\text { usas. }\end{array}$ & $\begin{array}{c}\text { Pregunta \# } 5 \\
\text { ¿De qué fuentes } \\
\text { consideras que has } \\
\text { aprendido el tipo de } \\
\text { ropa, accesorios y } \\
\text { posturas } \\
\text { corporales(si los } \\
\text { usas) que muestras } \\
\text { en tus fotos de perfil } \\
\text { en Facebook? ¿Por } \\
\text { qué? }\end{array}$ \\
\hline $\begin{array}{l}\text { J1 } \\
\text { (Hombre } \\
\text { de } 14 \\
\text { años) }\end{array}$ & $\begin{array}{l}\text { Es la belleza que uno } \\
\text { puede caracterizar, ya que } \\
\text { uno en una foto puede } \\
\text { quedar bien, también } \\
\text { utilizando filtro para la } \\
\text { belleza }\end{array}$ & $\begin{array}{l}\text { Pues a veces creo que deben } \\
\text { ser bellas y a veces no. Pues } \\
\text { desde que me guste a mí, } \\
\text { puede estar bien tenga o no } \\
\text { tenga filtros. Para ser bonita } \\
\text { la foto debe tener filtro bonito } \\
\text { o con una editación muy } \\
\text { buena, Así la puedo } \\
\text { considerar bella }\end{array}$ & $\begin{array}{l}\text { El uniforme del colegio o la } \\
\text { ropa que más me guste. Que } \\
\text { mi sonrisa se vea bien, lo } \\
\text { considero bello. }\end{array}$ & $\begin{array}{l}\text { Pues a veces hago poses con } \\
\text { las manos o me pongo unas } \\
\text { gafas para verme mejor. En } \\
\text { el colegio a veces salen } \\
\text { fotos con compañeros. Una } \\
\text { vez le puse a una con mi } \\
\text { amiga Issa un filtro de } \\
\text { perrito y quedamos bien, } \\
\text { entonces la publiqué }\end{array}$ & $\begin{array}{l}\text { A veces saco las } \\
\text { ideas de YouTube, de } \\
\text { los comerciales. Los } \\
\text { veo y digo me voy a } \\
\text { tomar una foto con } \\
\text { esa ropa, viendo } \\
\text { perfiles de Facebook, } \\
\text { miro como mis } \\
\text { compañeros se } \\
\text { visten, etc., así me } \\
\text { gusta y por eso me } \\
\text { visto así. }\end{array}$ \\
\hline $\begin{array}{l}\text { J2 } \\
\text { Mujer } \\
\text { de } 14 \\
\text { años }\end{array}$ & $\begin{array}{l}\text { Es la forma en que se } \\
\text { puede expresar la persona. } \\
\mathrm{Si} \text { deben ser bellas o } \\
\text { estéticas porque según la } \\
\text { foto tiene o no tiene like. }\end{array}$ & $\begin{array}{l}\text { Algo que lo haga resaltar a } \\
\text { uno, que demuestre que uno } \\
\text { realmente es importante, sin } \\
\text { importar los comentarios de } \\
\text { los demás. Según los colores } \\
\text { que use en la ropa se ve si }\end{array}$ & $\begin{array}{l}\text { Me gusta usar aretes grandes } \\
\text { que me resalten mucho y me } \\
\text { haga ver mejor. }\end{array}$ & $\begin{array}{l}\text { Me ha gustado experimentar } \\
\text { filtros que me hagan ver la } \\
\text { cara más redondita, me } \\
\text { gusta tomarme fotos donde } \\
\text { mi tía y subirlas y mostrar } \\
\text { cuando estoy feliz. }\end{array}$ & $\begin{array}{l}\text { De la publicidad, de } \\
\text { la moda y de mis } \\
\text { amigos porque se ven } \\
\text { cool. }\end{array}$ \\
\hline
\end{tabular}




\begin{tabular}{|c|c|c|c|c|c|}
\hline & & estás bello o no. & & & \\
\hline $\begin{array}{ll}\text { J3 } & \\
\text { Hombre } \\
\text { de } 15 \\
\text { años }\end{array}$ & $\begin{array}{l}\text { Es un medio de lucirse } \\
\text { frente a la gente para mirar } \\
\text { si es bonito o atractivo. }\end{array}$ & $\begin{array}{l}\text { Buen gesto, buen vestuario, } \\
\text { buenos accesorios, buen } \\
\text { fondo o no importa no tener } \\
\text { fondo, pero tratar de que la } \\
\text { foto ni tenga mal fondo. }\end{array}$ & $\begin{array}{l}\text { Ropa original y accesorios } \\
\text { propios para lucir bien en la } \\
\text { foto, gorras porque se ven } \\
\text { bacanas, pañoletas porque se } \\
\text { ven bacanas para lo original, } \\
\text { buen peinado porque es buena } \\
\text { presentación para mí. A } \\
\text { veces gestos de serio o } \\
\text { original, si es una foto que } \\
\text { tenga un buen momento, se } \\
\text { finge una sonrisa. }\end{array}$ & $\begin{array}{l}\text { Pues tengo varios recuerdos } \\
\text { en donde me he tomado } \\
\text { fotos de perfil felices. Una } \\
\text { vez aproveché que el cielo } \\
\text { estaba bien azul y me tomé } \\
\text { la foto y me gustó como } \\
\text { quedó y la edité a } \\
\text { posteriorizar y listo. }\end{array}$ & $\begin{array}{l}\text { Ninguna fuente } \\
\text { porque me gusta ser } \\
\text { original, solo yo. }\end{array}$ \\
\hline $\begin{array}{l}\text { J4 } \\
\text { Mujer } \\
\text { de } 15 \\
\text { años }\end{array}$ & $\begin{array}{l}\text { Estética es una vanidad } \\
\text { que todos manejamos, es } \\
\text { algo que a vista de } \\
\text { nosotros sea agradable. }\end{array}$ & $\begin{array}{l}\text { Debo verme bien, que me } \\
\text { guste a mí. La ropa debe estar } \\
\text { limpia, estar bien peinada y } \\
\text { cosas por el estilo. }\end{array}$ & $\begin{array}{l}\text { Uso maquillaje porque creo } \\
\text { que cambio un poco con él. } \\
\text { Aretes: me gusta usar } \\
\text { candongas y grandes porque } \\
\text { son llamativas y uno cambia } \\
\text { su apariencia. Anillos: entre } \\
\text { más llamativo mejor porque } \\
\text { que adorna las manos y se ve } \\
\text { más llamativo. }\end{array}$ & $\begin{array}{l}\text { Pues me gusta ver las } \\
\text { reacciones de los demás } \\
\text { cuando publico mis fotos de } \\
\text { perfil. Mi experiencia } \\
\text { personal es que siempre } \\
\text { estoy buscando lucir mejor } \\
\text { y usar cosas que me hagan } \\
\text { lucir mejor. }\end{array}$ & $\begin{array}{l}\text { Veo tutoriales en los } \\
\text { cuales hay chicas que } \\
\text { se arreglan bien. Hay } \\
\text { imágenes de } \\
\text { vestuarios muy } \\
\text { llamativos. También } \\
\text { en las películas hay } \\
\text { chicas que se visten } \\
\text { fuera de lo usual y } \\
\text { cotidiano. También } \\
\text { de mi familia tomo } \\
\text { ideas porque se } \\
\text { visten elegante, pero } \\
\text { a la vez sport. }\end{array}$ \\
\hline $\begin{array}{l}\text { J5 } \\
\text { Hombre } \\
\text { de } 14 \\
\text { años }\end{array}$ & $\begin{array}{l}\text { Para mí la estética es como } \\
\text { un concepto o un conjunto } \\
\text { de requisitos, por ejemplo, } \\
\text { señales, como una sonrisa, } \\
\text { un accesorio u otra cosa } \\
\text { para salir bien en una foto } \\
\text { de perfil. }\end{array}$ & $\begin{array}{l}\text { No siempre las fotos deben } \\
\text { ser bellas. Cuando son bellas } \\
\text { deben tener una buena } \\
\text { iluminación, un buen gesto y } \\
\text { mi forma de vestir. La ropa } \\
\text { que uso en mis fotos de perfil } \\
\text { les dan cierto toque a mis } \\
\text { fotos. }\end{array}$ & $\begin{array}{l}\text { Yo casi no me pongo } \\
\text { accesorios en mis fotos de } \\
\text { perfil, porque no me gusta. } \\
\text { Prefiero una foto de forma } \\
\text { casual. } \\
\text { Ya es normal que yo haga un } \\
\text { tipo de gesto en mis fotos de } \\
\text { perfil, el del dedo hacia } \\
\text { arriba, tiene un significado de } \\
\text { que todo está bien. }\end{array}$ & $\begin{array}{l}\text { Yo solo utilicé una gorra en } \\
\text { una foto de perfil que } \\
\text { porque me veía menos raro, } \\
\text { pero no me gustó }\end{array}$ & $\begin{array}{l}\text { Yo tomo las ideas de } \\
\text { varios lados: de } \\
\text { canales en YouTube, } \\
\text { de la forma como se } \\
\text { arregla mi familia, de } \\
\text { Facebook. }\end{array}$ \\
\hline J6 & La estética para mí es & Que la ropa que use no sea & Me gusta usar gafas porque & Una experiencia es que & Tomo mi estilo de las \\
\hline
\end{tabular}




\begin{tabular}{|c|c|c|c|c|c|}
\hline $\begin{array}{l}\text { Mujer } \\
\text { de } 16 \\
\text { años }\end{array}$ & $\begin{array}{l}\text { como uno se ven las fotos } \\
\text { y los accesorios, filtros, } \\
\text { fondos, etc. }\end{array}$ & $\begin{array}{l}\text { mostrona, usar poses, filtros, } \\
\text { accesorios y emojis. }\end{array}$ & $\begin{array}{l}\text { me hacen ver diferente en las } \\
\text { fotos. Las gafas me tapan los } \\
\text { ojos y me hacen ver mejor. La } \\
\text { sonrisa me hace sentir bien y } \\
\text { demuestra que estoy contenta, } \\
\text { la mano en el hombro me } \\
\text { hacer ver bien }\end{array}$ & $\begin{array}{l}\text { siempre les pregunto a mis } \\
\text { amigos como veo, si tienen } \\
\text { una reacción como } \\
\text { asombrada, les pregunto qué } \\
\text { no les gustó de mi foto. Eso } \\
\text { es importante porque me } \\
\text { hace sentir bien y saber } \\
\text { cómo me veo. }\end{array}$ & $\begin{array}{l}\text { redes sociales, de la } \\
\text { forma como se visten } \\
\text { mis amigos y a veces } \\
\text { mi familia. }\end{array}$ \\
\hline $\begin{array}{l}\text { J7 } \\
\text { Hombre } \\
\text { de } 14 \\
\text { años }\end{array}$ & $\begin{array}{l}\text { Es algo que a ti te gusta } \\
\text { demostrarlo y no te } \\
\text { importa lo que lo demás } \\
\text { piensen de ti. }\end{array}$ & $\begin{array}{l}\text { Que uno demuestre que es } \\
\text { feliz tomándoselas y que nos } \\
\text { sea una obligación. }\end{array}$ & $\begin{array}{l}\text { No, así el único accesorio } \\
\text { digamos es el reloj y una } \\
\text { pañoleta que me puede cubrir } \\
\text { una parte de la cara. También } \\
\text { utilizo una sonrisa y una } \\
\text { mirada que tiene que ver con } \\
\text { la belleza }\end{array}$ & $\begin{array}{l}\text { Trato de tener una buena } \\
\text { actitud en las fotos. Trato de } \\
\text { que las fotos que me tomo } \\
\text { sean del agrado de los } \\
\text { demás. }\end{array}$ & $\begin{array}{l}\text { De los programas de } \\
\text { televisión, de de } \\
\text { Facebook, de mi } \\
\text { familia, de las } \\
\text { revistas, de la forma } \\
\text { como se visten mis } \\
\text { amigos }\end{array}$ \\
\hline $\begin{array}{l}\text { J8 } \\
\text { Mujer } \\
\text { de } 14 \\
\text { años }\end{array}$ & $\begin{array}{l}\text { Para mi la estética es la } \\
\text { autoestima que me hace } \\
\text { fuerte y arreglárselas para } \\
\text { verse bien. }\end{array}$ & $\begin{array}{l}\text { Para mí una foto de perfil } \\
\text { debe tener un buen gesto, } \\
\text { buena ropa, lo que yo } \\
\text { considero es eso. Los } \\
\text { accesorios que yo creo es } \\
\text { estar a la moda. }\end{array}$ & $\begin{array}{l}\text { Algunas veces uso aretes, le } \\
\text { dan el toque de feminidad, } \\
\text { aunque a veces se me olvida } \\
\text { ponérmelos. Gafas porque, no } \\
\text { sé le dan como el toque de } \\
\text { feminidad. Hago poses con la } \\
\text { mano, la cintura y con la } \\
\text { mano con la señal de paz. El } \\
\text { gesto de la sonrisa feliz y una } \\
\text { mano en la cintura } \\
\text { manifestando la felicidad. }\end{array}$ & $\begin{array}{l}\text { Yo aprendí de mi prima a } \\
\text { arreglarme para las fotos de } \\
\text { perfil, porque ella se } \\
\text { combina la ropa muy linda. } \\
\text { Me gusta sentirme femenina } \\
\text { en mis fotos de perfil. }\end{array}$ & $\begin{array}{l}\text { De Facebook y } \\
\text { algunas páginas de } \\
\text { internet que veo. }\end{array}$ \\
\hline J9 & $\begin{array}{l}\text { La estética es para mí lo } \\
\text { bonito, la forma de vestir, } \\
\text { su postura, sus muecas. }\end{array}$ & $\begin{array}{l}\text { Mi condición es tener una } \\
\text { buena presentación y un buen } \\
\text { fondo. }\end{array}$ & $\begin{array}{l}\text { La ropa que uso es la mayoría } \\
\text { es unos zapatos, no tanto } \\
\text { colorido, pero llamativos, un } \\
\text { chaleco o una chaqueta, } \\
\text { pantalón, jean o sudadera. A } \\
\text { veces uso anillos, porque a mí } \\
\text { me gustan o vez en cuando las } \\
\text { cadenas. No me gustan las } \\
\text { gorras, ni aretes ni pañoletas. } \\
\text { Hago caras como sacando la }\end{array}$ & $\begin{array}{l}\text { Me ha gustado Facebook } \\
\text { porque publican fotos de } \\
\text { perfil divertidas } \quad \text { o } \\
\text { llamativas, por eso ahí uno } \\
\text { puede aprender. }\end{array}$ & $\begin{array}{l}\text { Yo aprendí del grupo } \\
\text { de amigos, cuando } \\
\text { unos amigos se visten } \\
\text { muy bien y uno } \\
\text { quiere algo igual. De } \\
\text { las revistas virtuales, } \\
\text { cuando hay ropa } \\
\text { buena y uno quiere } \\
\text { tenerla. }\end{array}$ \\
\hline
\end{tabular}




\begin{tabular}{|c|c|c|c|c|c|}
\hline & & & $\begin{array}{l}\text { lengua, poniendo caras de } \\
\text { serio, triste, malgeniado o } \\
\text { caras chistosas. }\end{array}$ & & \\
\hline $\begin{array}{l}\text { J10 } \\
\text { Mujer } \\
\text { de } 14 \\
\text { años }\end{array}$ & $\begin{array}{l}\text { La estética o belleza es ser } \\
\text { uno mismo en las fotos, no } \\
\text { poner tantos filtros o } \\
\text { editar, estar cómodos con } \\
\text { nosotros. }\end{array}$ & $\begin{array}{l}\text { Que yo sienta que salí bonita, } \\
\text { que esté con una persona que } \\
\text { quiero, que esté de acuerdo } \\
\text { con lo que tiene la foto. }\end{array}$ & $\begin{array}{l}\text { Sí usos accesorios como } \\
\text { anillos, aretes, moñas, algunas } \\
\text { veces porque me gusta como } \\
\text { se ve. Me pongo la mejor ropa } \\
\text { para salir bien en las fotos o } \\
\text { tal vez puede ser una camisa } \\
\text { de una banda que tu } \\
\text { consideres bella. También uso } \\
\text { aretes porque creo que se ve } \\
\text { mejor la foto, gorras depende } \\
\text { de dónde esté, joyas porque } \\
\text { nunca me las quito para nada. } \\
\text { A veces intento gestos que } \\
\text { veo y miro si me dicen que así } \\
\text { me veo mejor. Algunas veces } \\
\text { hago signos con las manos y } \\
\text { gestos como sacar la lengua o } \\
\text { sonreír o con una mano en la } \\
\text { cintura. Considero que me } \\
\text { pueden hacer ver más tierna o } \\
\text { más chistosa. }\end{array}$ & $\begin{array}{l}\text { Yo trato de preguntarle a los } \\
\text { demás si me veo bonita y } \\
\text { tierna y depende de lo que } \\
\text { me digan subo la foto o no. } \\
\text { Me siento un poco } \\
\text { desconfiada y hasta me } \\
\text { puede llegar a bajar la } \\
\text { autoestima, ya que soy muy } \\
\text { miedos con lo que dicen los } \\
\text { demás. }\end{array}$ & $\begin{array}{l}\text { Algunas veces veo a } \\
\text { mis amigos o } \\
\text { tutoriales de } \\
\text { YouTube hay } \\
\text { accesorios que se ven } \\
\text { bien o que inventan } \\
\text { para las fotos. }\end{array}$ \\
\hline $\begin{array}{l}\text { J11 } \\
\text { Hombre } \\
\text { de } 16 \\
\text { años }\end{array}$ & $\begin{array}{l}\text { Para mi algo estético es } \\
\text { vestirse bien, arreglarse, } \\
\text { maquillarse, asearse. }\end{array}$ & $\begin{array}{l}\text { Usar ropa juvenil a la moda, } \\
\text { porque me encanta tener lo } \\
\text { último de la moda. }\end{array}$ & $\begin{array}{l}\text { Solo una fue unos audífonos, } \\
\text { una vez utilicé una gorra } \\
\text { porque me gusta la moda de } \\
\text { ese tiempo. La ropa que veo } \\
\text { en los demás porque me } \\
\text { gusta. No suelo hacer poses, } \\
\text { solo un gesto de feliz, porque } \\
\text { quiero demostrar felicidad. }\end{array}$ & $\begin{array}{l}\text { Una vez fui al Jaime Duque } \\
\text { y me tomé varias fotos de } \\
\text { perfil. Me gusta tomarme y } \\
\text { subir fotos en días de } \\
\text { alegría. }\end{array}$ & $\begin{array}{l}\text { Amigos, familia, } \\
\text { televisión. }\end{array}$ \\
\hline $\mathrm{J} 12$ & $\begin{array}{l}\text { Es lo bonito, la forma en } \\
\text { que una persona se } \\
\text { expresa en sus fotos. Cada } \\
\text { pose detalle, dice mucho } \\
\text { de una persona. }\end{array}$ & $\begin{array}{l}\text { Debe tener un artefacto o } \\
\text { accesorio, buen fondo entre } \\
\text { otros. }\end{array}$ & $\begin{array}{l}\text { La ropa es la última que me } \\
\text { han comprado, limpia y bien } \\
\text { portada. Si vistes ropa vieja, } \\
\text { rota o mala se va a ver y a } \\
\text { notar, haciendo que la foto se }\end{array}$ & $\begin{array}{l}\text { Mis amigos me } \\
\text { recomiendan que usar en las } \\
\text { fotos. Me gustan las fotos } \\
\text { bellas en Facebook que } \\
\text { tengan muchos likes. La }\end{array}$ & $\begin{array}{l}\text { De la publicidad, ya } \\
\text { que en esta salen } \\
\text { varias ofertas, con } \\
\text { ropa muy bella, de } \\
\text { Facebook, al ver }\end{array}$ \\
\hline
\end{tabular}




\begin{tabular}{|c|c|c|c|c|c|}
\hline & & & $\begin{array}{l}\text { vea fea. Utilizo gorras ya que } \\
\text { siento que me veo genial con } \\
\text { estas. Uso poses ya que con } \\
\text { estas poses muestro el lado de } \\
\text { la cara o el cuerpo bueno, } \\
\text { donde se ve más bello }\end{array}$ & $\begin{array}{l}\text { ropa y accesorios y los } \\
\text { pequeños detalles pueden } \\
\text { llegar a marcar la diferencia } \\
\text { en una foto. }\end{array}$ & $\begin{array}{l}\text { personas con la foto } \\
\text { de perfil, con buena } \\
\text { ropa, me llevó a } \\
\text { utilizarla, con buena } \\
\text { marca y limpias, de } \\
\text { películas, como } \\
\text { ponen la ropa, de qué } \\
\text { forma, con } \\
\text { accesorios, de mi } \\
\text { familia. A mi familia } \\
\text { s ele ve bien la ropa, } \\
\text { entonces trato de } \\
\text { imitarlos un poco, de } \\
\text { conocidos, conozco a } \\
\text { gente con un estilo de } \\
\text { ropa genial que hace } \\
\text { que parezcan gente } \\
\text { de gran belleza. De } \\
\text { todos ellos también } \\
\text { he aprendido a usar } \\
\text { gorras }\end{array}$ \\
\hline $\begin{array}{l}\text { J13 } \\
\text { Mujer } \\
\text { de } 14 \\
\text { años }\end{array}$ & $\begin{array}{l}\text { Para mí es sobre la } \\
\text { apariencia, también los } \\
\text { sentimientos, pero } \\
\text { lastimosamente la que más } \\
\text { importa en esta sociedad } \\
\text { es la apariencia. }\end{array}$ & $\begin{array}{l}\text { En lo que me enfoco es en } \\
\text { que mi cara debe quedar bien, } \\
\text { mis ojos, mi sonrisa, mis } \\
\text { labios. Creo que la ropa } \\
\text { también puede ayudar para } \\
\text { que la foto quede bonita, } \\
\text { porque hay ropa que resalta } \\
\text { partes del cuerpo. }\end{array}$ & $\begin{array}{l}\text { Solo utilizo ropa bonita, } \\
\text { aretes y un collar, porque me } \\
\text { gusta como se me ven. La } \\
\text { mayoría de veces solo sonrío. } \\
\text { Me gusta mucho mi sonrisa y } \\
\text { significa que estoy segura de } \\
\text { sí misma }\end{array}$ & $\begin{array}{l}\text { Creo que mi experiencia es } \\
\text { que creo que a los demás les } \\
\text { gusta de mis fotos la cara y } \\
\text { el cuerpo, pero me importa } \\
\text { más que me gusten a mí las } \\
\text { fotos. }\end{array}$ & $\begin{array}{l}\text { Me gustan algunos } \\
\text { estilos que tienen mis } \\
\text { amigas, en YouTube } \\
\text { también veo gran } \\
\text { variedad } \\
\text { accesorios y de ahí } \\
\text { me enfoco en } \\
\text { conseguir esos, hay } \\
\text { varios videos en } \\
\text { donde nos explican } \\
\text { que la sonrisa que } \\
\text { ayuda a que tu foto } \\
\text { quede bonita. }\end{array}$ \\
\hline $\begin{array}{l}\text { J14 } \\
\text { Hombre } \\
\text { de } \quad 14 \\
\end{array}$ & $\begin{array}{l}\text { Para la mí es la belleza al } \\
\text { tomar la foto, lo bonito, si } \\
\text { tienes actitud positiva, de }\end{array}$ & $\begin{array}{l}\text { La condición que más importa } \\
\text { es que yo me vea bien, } \\
\text { además de eso, pues ponerle }\end{array}$ & $\begin{array}{l}\text { La ropa varía de donde esté, } \\
\text { pero pues uno se trata de } \\
\text { arreglar bien. Digamos si }\end{array}$ & $\begin{array}{l}\text { Creo que cuando recibo } \\
\text { likes o cosas chéveres la } \\
\text { foto quedó bien, pero si no }\end{array}$ & $\begin{array}{l}\text { Pues he aprendido de } \\
\text { acuerdo a la gente } \\
\text { que me gusta como }\end{array}$ \\
\hline
\end{tabular}




\begin{tabular}{|c|c|c|c|c|c|}
\hline años & $\begin{array}{l}\text { acuerdo a eso, tú decides } \\
\text { si lo dejas o puedes dar } \\
\text { mucho más, también los } \\
\text { gestos, las poses los } \\
\text { amigos, todo eso que tan } \\
\text { bello te queda en la foto. }\end{array}$ & $\begin{array}{l}\text { filtros o emoticones, depende } \\
\text { del estilo de la foto que sea. }\end{array}$ & $\begin{array}{l}\text { estoy en la calle tomo con } \\
\text { ropa de calle o en una fiesta, } \\
\text { con ropa elegante queda la } \\
\text { foto., entonces la ropa varía. } \\
\text { mucho depende del sitio de } \\
\text { donde esté. Pues además de } \\
\text { mis gorras, no me gusta usar } \\
\text { nada más porque yo pienso } \\
\text { que uno sin ningún accesorio } \\
\text { es bello y además no se } \\
\text { necesita algo para ser bello, si } \\
\text { uno se considera más bello. } \\
\text { También uso gafas porque las } \\
\text { necesito. En una utilicé } \\
\text { guantes porque no sé, en esa } \\
\text { creía que yo me veía mucho } \\
\text { mejor así. A veces uso filtros } \\
\text { y emoticones que me } \\
\text { enseñaron a usar, a veces } \\
\text { salgo haciendo el signo de la } \\
\text { la paz. }\end{array}$ & $\begin{array}{l}\text { significa que algo no quedó } \\
\text { bien. }\end{array}$ & $\begin{array}{l}\text { se viste, o de mis } \\
\text { amigos que me dicen } \\
\text { cómo se hace o como } \\
\text { se toma una foto, } \\
\text { también de las } \\
\text { posturas que veo en } \\
\text { mi familia o en las } \\
\text { redes sociales o de } \\
\text { mis amigos. }\end{array}$ \\
\hline J15 & $\begin{array}{l}\text { Para mi es estar bonito al } \\
\text { natural y la confianza en sí } \\
\text { misma. }\end{array}$ & $\begin{array}{l}\text { Una condición sería la } \\
\text { confianza, aplicarse } \\
\text { maquillaje y la ropa. Siempre } \\
\text { una ropa presentable o la ropa } \\
\text { que concuerde con mi } \\
\text { emoción. A mí me llama } \\
\text { mucho la atención la ropa } \\
\text { elegante y eso a mí me ayuda } \\
\text { a escoger mi ropa para verme } \\
\text { puppi. }\end{array}$ & $\begin{array}{l}\text { Ropa elegante. Yo soy muy } \\
\text { natural y o me gusta usar } \\
\text { accesorios, aretes porque le } \\
\text { dan más brillo a mi cara. Yo } \\
\text { siempre busco algo elegante } \\
\text { en mis gestos y emociones. } \\
\text { Mis gestos son emociones que } \\
\text { siento y con las que me } \\
\text { conformo a mi gusto y mis } \\
\text { poses tienen un significado } \\
\text { algo pensativo. }\end{array}$ & $\begin{array}{l}\text { En mis fotos de perfil me } \\
\text { gusta sentirme bella y } \\
\text { segura de mis emociones. Si } \\
\text { miro que alguna foto no les } \\
\text { agrada a otros, simplemente } \\
\text { la borro y me tomo otra, } \\
\text { porque es muy importante } \\
\text { para mí, así me doy cuenta } \\
\text { de que no soy fea, que tal } \\
\text { vez mi look lo tenga que } \\
\text { cambiar, etc.,. }\end{array}$ & $\begin{array}{l}\text { Aprendo de internet, } \\
\text { de otras redes } \\
\text { sociales, de la ropa } \\
\text { que usa mi familia, } \\
\text { de revistas } \\
\text { imágenes } \\
\text { navegación. }\end{array}$ \\
\hline J16 & $\begin{array}{l}\text { No es solo alguien que sea } \\
\text { lindo, sino es lo que lleva } \\
\text { en su interior, si es una } \\
\text { buena persona. }\end{array}$ & $\begin{array}{l}\text { Que tenga un buen fondo y } \\
\text { que sea en un momento } \\
\text { exacto o adecuado. Creo que, } \\
\text { si es un buen momento uno, } \\
\text { tienes buena ropa, la foto se }\end{array}$ & $\begin{array}{l}\text { Me gusta usar buena ropa. No } \\
\text { me gustan Ios accesorios, solo } \\
\text { gorras, porque creo que con } \\
\text { ese accesorio la ropa se verá } \\
\text { muy bien. A veces hago el }\end{array}$ & $\begin{array}{l}\text { Yo hago gestos en mis fotos } \\
\text { de perfil porque me gusta, } \\
\text { no para verme bello o } \\
\text { estético. Creo que ha sido } \\
\text { importante usar buena ropa }\end{array}$ & $\begin{array}{l}\text { Los programas de } \\
\text { televisión porque } \\
\text { creo que tienen un } \\
\text { buen vestuario, en los } \\
\text { canales de YouTube }\end{array}$ \\
\hline
\end{tabular}




\begin{tabular}{|c|c|c|c|c|c|}
\hline & & puede embellecer. & $\begin{array}{l}\text { gesto de paz o gestos } \\
\text { graciosos. Gestos como cerrar } \\
\text { los ojos y sacar la lengua o los } \\
\text { cachetes inflados. El } \\
\text { significado para mí es que son } \\
\text { divertidas o graciosas. }\end{array}$ & $\begin{array}{l}\text { y que los demás vean la foto } \\
\text { y digan que la foto quedó } \\
\text { buena, que tiene buena ropa } \\
\text { y buen fondo, etc. }\end{array}$ & $\begin{array}{l}\text { siempre se ponen la } \\
\text { ropa que quieren, en } \\
\text { el Facebook porque } \\
\text { en las fotos de perfil } \\
\text { la gente tiene buena } \\
\text { ropa y mi familia } \\
\text { también } \\
\begin{array}{l}\text { hacen porque } \\
\text { graciosos }\end{array}\end{array}$ \\
\hline $\mathrm{J} 17$ & $\begin{array}{l}\text { Para mi la estética no es } \\
\text { tanto el tema del } \\
\text { maquillaje o algo así, trata } \\
\text { es de cuidarse y arreglarse, } \\
\text { no tan exageradamente, } \\
\text { sino que mejor decente y } \\
\text { bonito. }\end{array}$ & $\begin{array}{l}\text { Yo creo que una foto debe ser } \\
\text { linda, pues uno escoge la } \\
\text { mejor foto y la que más le } \\
\text { guste a uno, de acuerdo a } \\
\text { como uno lo quiera Me gusta } \\
\text { usar jeans, ombligueras o } \\
\text { busos. Me gusta investigar } \\
\text { más cómo combinar la ropa } \\
\text { en Facebook }\end{array}$ & $\begin{array}{l}\text { Me gusta usar jeans, } \\
\text { ombligueras o busos. Me } \\
\text { gusta investigar más cómo } \\
\text { combinar la ropa en } \\
\text { Facebook. Aretes para lucir } \\
\text { más mis orejas y no verme tan } \\
\text { lambida, labial para no verme } \\
\text { tan pálida, anillos para llamar } \\
\text { la atención, etc. Sonreír } \\
\text { también es como lindo, } \\
\text { porque ven que uno no es } \\
\text { amargado, mandando pico o } \\
\text { algo así, yo creo que se ve } \\
\text { como coqueto. }\end{array}$ & $\begin{array}{l}\text { Pues yo en mis fotos de } \\
\text { perfil utilizo más lo } \\
\text { personal, o sea lo mío y no } \\
\text { me gusta editar mucho las } \\
\text { fotos con ojos, aretes, labial } \\
\text { y cosas así. Es importante } \\
\text { cuando los demás hacen } \\
\text { comentarios de mis fotos en } \\
\text { un buen sentido. }\end{array}$ & $\begin{array}{l}\text { A veces me copio de } \\
\text { los gestos que hacen } \\
\text { otras personas, de } \\
\text { revistas, de Facebook } \\
\text { y otras redes sociales. }\end{array}$ \\
\hline $\begin{array}{l}\text { J18 } \\
\text { Hombre } \\
\text { de } 15 \\
\text { años }\end{array}$ & $\begin{array}{l}\text { En algo bello que tiene } \\
\text { mucho color, que sea } \\
\text { animad, reluciente y que } \\
\text { llame la atención. }\end{array}$ & $\begin{array}{l}\text { Las fotos que yo publique } \\
\text { deben ser bellas, ya que es } \\
\text { para que la gente tenga un } \\
\text { punto de vista bueno de uno y } \\
\text { para que a las personas les } \\
\text { gusten y llamen la atención. } \\
\text { Las condiciones que debe } \\
\text { tener mi foto de perfil es que } \\
\text { tenga color, que tenga buen } \\
\text { fondo y buena ropa, para que } \\
\text { se vea bella la foto. }\end{array}$ & $\begin{array}{l}\text { La ropa de perfil que uso se } \\
\text { puede embellecer, ya que una } \\
\text { ropa linda puede llamar la } \\
\text { atención y hace que uno se } \\
\text { vea mejor. Uso accesorio en } \\
\text { mis fotos de perfil como } \\
\text { gafas, porque me hacen ver } \\
\text { mejor mi rostro en esas } \\
\text { ocasiones, para tener mejor } \\
\text { sytyle. Joyas, uso anillos para } \\
\text { lucir mejor y llamar la } \\
\text { atención por verme mejor. } \\
\text { Las posturas son de medio } \\
\text { lado, mirando hacia los lados }\end{array}$ & $\begin{array}{l}\text { Me gusta verme y sentirme } \\
\text { bello en las fotos. Me siento } \\
\text { muy agradable porque a la } \\
\text { gente le gustan usando } \\
\text { posturas, ropa y gafas } \\
\text { bonitas. }\end{array}$ & $\begin{array}{l}\text { Saco mi estilo de la } \\
\text { publicidad, de videos } \\
\text { en YouTube, de } \\
\text { películas, de videos } \\
\text { musicales, Facebook } \\
\text { y páginas de Internet. }\end{array}$ \\
\hline
\end{tabular}




\begin{tabular}{|c|c|c|c|c|c|}
\hline & & & $\begin{array}{l}\text { y pues me gusta porque se ven } \\
\text { bonitas y llamativas }\end{array}$ & & \\
\hline $\begin{array}{l}\text { J19 } \\
\text { Mujer } \\
\text { de } 14 \\
\text { años }\end{array}$ & $\begin{array}{l}\text { Pues para mi es la } \\
\text { apariencia de las personas } \\
\text { bonita, cara, buen cuerpo y } \\
\text { también los emojis y los } \\
\text { filtros }\end{array}$ & $\begin{array}{l}\text { Salir bien presentada y que } \\
\text { quede bien la foto. La ropa } \\
\text { debe ser bonita y no tan vieja } \\
\text { porque si no, no se va a ver } \\
\text { tan bien, en cambio si tienes } \\
\text { la más bonita, se va a ver } \\
\text { mejor. }\end{array}$ & $\begin{array}{l}\text { El único accesorio que uso } \\
\text { son los aretes, porque uno se } \\
\text { ve bien con los aretes. Uso } \\
\text { gestos porque me gusta como } \\
\text { salgo con los gestos que } \\
\text { hacen mis conocidos }\end{array}$ & $\begin{array}{l}\text { Pues me gusta usar ropa } \\
\text { bonita y con los likes que } \\
\text { recibo con mis fotos sé si a } \\
\text { mis conocidos les gustaron, } \\
\text { pues eso no es tan } \\
\text { importante, pero sí me gusta } \\
\text { que den likes y que } \\
\text { comenten. }\end{array}$ & $\begin{array}{lrr}\text { Saco ideas } & \text { de } & \text { las } \\
\text { fotos de } & & \text { mis } \\
\text { conocidos. } & & \end{array}$ \\
\hline $\begin{array}{l}\text { J20 } \\
\text { Hombre } \\
\text { de } \quad 15 \\
\text { años }\end{array}$ & $\begin{array}{l}\text { Lo estético es en mis fotos } \\
\text { las poses, los gestos de la } \\
\text { cara, el fondo, la ropa y el } \\
\text { estado de ánimo que esté } \\
\text { para la foto. }\end{array}$ & $\begin{array}{l}\text { Estar feliz en el momento en } \\
\text { que tomé la foto y el día } \\
\text { completo, porque si lo subí, } \\
\text { son por algo importante o } \\
\text { feliz de mi vida. }\end{array}$ & $\begin{array}{l}\text { Me pongo la ropa que lleve } \\
\text { puesta ese día. Uso gorras, } \\
\text { cadenas, relojes, manillas } \\
\text { porque me hacen ver más } \\
\text { guapo, también posturas } \\
\text { porque mejoran la belleza de } \\
\text { la foto para estar feliz de lo } \\
\text { que se tomó. Pongo figuras } \\
\text { con las manos poniendo los } \\
\text { dos dedos arriba o gestos con } \\
\text { la cara sacando la lengua, o } \\
\text { fingir que estoy enojado, me } \\
\text { divierte hacerla y la foto se ve } \\
\text { más bella. }\end{array}$ & $\begin{array}{l}\text { Mi experiencia es que trato } \\
\text { de ponerme de forma } \\
\text { moderna para los demás, yo } \\
\text { trato de vestirme a mí } \\
\text { mismo como yo quiera. } \\
\text { Cuando he publicado fotos y } \\
\text { les gustan a otros me gusta, } \\
\text { pero si no, trato de no darle } \\
\text { tanta importancia y borro } \\
\text { los comentarios que no me } \\
\text { gusten. }\end{array}$ & $\begin{array}{l}\text { Me gusta ponerme de } \\
\text { forma moderna como } \\
\text { en las películas, para } \\
\text { verme iguales o } \\
\text { parecidos a ellos, } \\
\text { para estar como la } \\
\text { familia por su gran } \\
\text { forma que tienen, ya } \\
\text { que me pone a mí y a } \\
\text { la foto más bella al } \\
\text { momento de verla. } \\
\text { También de videos y } \\
\text { canales en YouTube. }\end{array}$ \\
\hline $\mathrm{J} 21$ & $\begin{array}{l}\text { Para mí lo estético es lo } \\
\text { bonito en una foto de } \\
\text { perfil, es más lo que } \\
\text { demuestres ser, no tanto es } \\
\text { físicamente, para mi es lo } \\
\text { que eres, sientes y } \\
\text { demuestras en una foto. }\end{array}$ & $\begin{array}{l}\text { Que utilice la ropa que me } \\
\text { guste y que me sienta cómoda } \\
\text { con ella. Que haya sido } \\
\text { tomada en un lugar cómodo y } \\
\text { tranquilo, que esté alegre en } \\
\text { el momento, que me vea } \\
\text { linda. }\end{array}$ & $\begin{array}{l}\text { Uso ropa sencilla, cómoda, } \\
\text { normalmente jeans al cuerpo, } \\
\text { blusas sueltas, tenis o zapatos } \\
\text { bajos, chaqueta suelta o sin } \\
\text { chaqueta, uso aretes porque } \\
\text { brillan y me hace ver } \\
\text { reluciente, no uso otros } \\
\text { accesorios porque no me } \\
\text { gustan }\end{array}$ & $\begin{array}{l}\text { Soy un poco indecisa para } \\
\text { escoger accesorios para mis } \\
\text { fotos de perfil. Trato de } \\
\text { demostrar lo que soy, lo que } \\
\text { me gusta, mi estilo y a veces } \\
\text { puede que distingan mi } \\
\text { personalidad. }\end{array}$ & $\begin{array}{l}\text { De canales de } \\
\text { YouTube, porque veo } \\
\text { videos de moda y } \\
\text { escojo lo que me } \\
\text { gusta y lo adapto, del } \\
\text { tipo de ropa que usa } \\
\text { mi hermana, ella me } \\
\text { ayuda y me copeo de } \\
\text { ella por veces., de } \\
\text { revistas porque hay } \\
\text { varias opciones y las } \\
\text { adapto a mí. }\end{array}$ \\
\hline $\mathrm{J} 22$ & Pues la estética es como la & Pues la foto que yo quiera & Pues alguna de la mayoría de & Mi experiencia es que me & \\
\hline
\end{tabular}




\begin{tabular}{|c|c|c|c|c|c|}
\hline $\begin{array}{l}\text { Hombre } \\
\text { de } 17 \\
\text { años }\end{array}$ & $\begin{array}{l}\text { personalización de uno, } \\
\text { como la persona que lo } \\
\text { acompaña a todos lados. }\end{array}$ & $\begin{array}{l}\text { publicar tendrá que tener } \\
\text { belleza, filtros, fondo, etc. La } \\
\text { mayoría de fotos que yo tomo } \\
\text { a mí me quedan bien, porque } \\
\text { la belleza está en el interior de } \\
\text { uno.. }\end{array}$ & $\begin{array}{l}\text { la ropa de uno puede ser: } \\
\text { chaquetas, busos, pantalón, } \\
\text { camisa, zapatos, etc. La } \\
\text { mayoría de accesorios son } \\
\text { buso, pantalones y zapatillas. } \\
\text { Yo prefería utilizar sacos } \\
\text { porque en todas las ocasiones } \\
\text { a mí me sale con la ropa. Yo } \\
\text { en la mayoría de fotos hago } \\
\text { gestos y poses haciendo } \\
\text { cualquier figura y en los } \\
\text { gestos con la boca, pues los } \\
\text { gestos hacen en la foto como } \\
\text { que se vea gracioso. Las poses } \\
\text { son como para uno llamar la } \\
\text { atención. }\end{array}$ & $\begin{array}{l}\text { gusta que mis fotos llamen } \\
\text { la atención, por ejemplo, si } \\
\text { es un cumpleaños, uno tiene } \\
\text { que ser agradable y que los } \\
\text { compañeros den una opinión } \\
\text { de la foto que uno publica. } \\
\text { También me gusta publicar } \\
\text { fotos que expresen } \\
\text { recuerdos importantes, } \\
\text { como mi primera comunión } \\
\text { o días felices. }\end{array}$ & $\begin{array}{l}\text { Miro como se visten } \\
\text { o qué usan mis } \\
\text { amigos, en Facebook } \\
\text { y otras redes sociales } \\
\text { en las que yo casi } \\
\text { público. }\end{array}$ \\
\hline $\begin{array}{l}\text { J23 } \\
\text { Mujer } \\
\text { de } 15 \\
\text { años }\end{array}$ & $\begin{array}{l}\text { Lo estético es para mí la } \\
\text { belleza que está a nuestro } \\
\text { alrededor al tomar una } \\
\text { foto, y se mira cuando } \\
\text { miramos nuestro perfil de } \\
\text { Facebook. }\end{array}$ & $\begin{array}{l}\text { Lo que considero en la foto } \\
\text { debe tener todo bonito en el } \\
\text { fondo del perfil, , el cabello, } \\
\text { la cara y las expresiones. }\end{array}$ & $\begin{array}{l}\text { Por lo general utilizo } \\
\text { sudaderas, el uniforme o } \\
\text { cuando estamos en reuniones } \\
\text { lo casual es la ropa que tengo. } \\
\text { Uso gafas porque me gusta } \\
\text { que estén en mis fotos de } \\
\text { perfil y las utilizo cuando veo } \\
\text { que la foto se va a ver bien, o } \\
\text { si no utilizo otra clase de } \\
\text { accesorios para que aparezcan } \\
\text { en las fotos. Uso gestos como } \\
\text { por ejemplo picos o las } \\
\text { manos, es lo que más utilizo } \\
\text { en mis fotos así que es } \\
\text { normal. La sonrisa } \\
\text { generalmente la utilizo en } \\
\text { muchas de mis fotos }\end{array}$ & $\begin{array}{l}\text { Muchas veces nos ponemos } \\
\text { a ensayar con mis amigas } \\
\text { que qué labiales, poses nos } \\
\text { quedan mejor en las fotos de } \\
\text { perfil, peinados locos. Lo } \\
\text { importante es que mis fotos } \\
\text { me gusten y que sean } \\
\text { diferentes o que me gusten a } \\
\text { mí por lo general. }\end{array}$ & $\begin{array}{l}\text { Algunas veces utilizo } \\
\text { poses que hacen } \\
\text { algunos conocidos y } \\
\text { otras personas que } \\
\text { conozco y del tipo de } \\
\text { ropa que usan en mi } \\
\text { familia. }\end{array}$ \\
\hline $\begin{array}{l}\text { J24 } \\
\text { Hombre } \\
\text { de } 16\end{array}$ & $\begin{array}{l}\text { Para mí la estética es la } \\
\text { belleza perfecta, imagen } \\
\text { que uno figura y estilo, ya } \\
\text { que el ser humano le atrae }\end{array}$ & $\begin{array}{l}\text { Tiene que ser representativa y } \\
\text { expresar un sentimiento. }\end{array}$ & $\begin{array}{l}\text { Ropa nueva por lo general, } \\
\text { que me sienta cómodo con } \\
\text { ella. No uso accesorios a } \\
\text { menos de que ya sea una }\end{array}$ & $\begin{array}{l}\text { Creo que uno en las fotos de } \\
\text { perfil debe tener su propi } \\
\text { estilo y es lo que hago en } \\
\text { cuanto al tema de la ropa. }\end{array}$ & $\begin{array}{l}\text { De la televisión ya } \\
\text { que me parece que } \\
\text { una persona trate de } \\
\text { parecerse a una }\end{array}$ \\
\hline
\end{tabular}




\begin{tabular}{|c|c|c|c|c|c|}
\hline & $\begin{array}{l}\text { todo lo que sea explicable } \\
\text { para él o entendible. }\end{array}$ & & $\begin{array}{l}\text { necesidad como los lentes. } \\
\text { Uso posturas si yo quiero } \\
\text { representar cosas que estén } \\
\text { sucediendo. }\end{array}$ & $\begin{array}{l}\text { Yo expreso en mis fotos lo } \\
\text { que esté pasando o yo esté } \\
\text { sintiendo. Si no me dan like } \\
\text { a mis fotos, no me es muy } \\
\text { importante ya que significa } \\
\text { que tiene sus razones para } \\
\text { no creerlo. }\end{array}$ & $\begin{array}{l}\text { persona o personaje } \\
\text { que admira. }\end{array}$ \\
\hline $\begin{array}{l}\text { J25 } \\
\text { Mujer } \\
\text { de } 15 \\
\text { años }\end{array}$ & $\begin{array}{l}\text { Es la expresión del rostro } \\
\text { y el agrado que se siente al } \\
\text { verlo. }\end{array}$ & $\begin{array}{l}\text { Que la atención para poder } \\
\text { verme bien, mirada bonita, } \\
\text { cabello organizado, fondo } \\
\text { bien iluminado. }\end{array}$ & $\begin{array}{l}\text { Ropa ajustada, camisas manga } \\
\text { larga que se muestre atractiva. } \\
\text { No uso muchos accesorios } \\
\text { porque no me gusta verme tan } \\
\text { cargada de cosas, tal vez más } \\
\text { grande, pero todavía no. Uso } \\
\text { aretes para verme femenina. } \\
\text { Uso algunos gestos y posturas } \\
\text { para verme bien como de } \\
\text { medio lado: define mi cuerpo, } \\
\text { cara seria: me hace ver } \\
\text { tranquila. }\end{array}$ & $\begin{array}{l}\text { Me gusta publicar fotos de } \\
\text { perfil que tengan recuerdos } \\
\text { de regalos y ocasiones } \\
\text { especiales. } \\
\text { aparecer seria o de paseo. } \\
\text { Probar varias caras de } \\
\text { estados de ánimo diferentes } \\
\text { como sonriente, curiosa, } \\
\text { feliz o filtros de felicidad y } \\
\text { para atraer la atención del } \\
\text { que me gusta. }\end{array}$ & $\begin{array}{l}\text { De programas de TV: } \\
\text { porque veo actrices } \\
\text { muy bonitas y pues } \\
\text { me gusta su forma de } \\
\text { vestir. Canales de } \\
\text { YouTube: porque me } \\
\text { agrada la forma de } \\
\text { versen de mis } \\
\text { Youtubers favoritos. } \\
\text { Páginas de internet: } \\
\text { porque me aconsejan } \\
\text { como debo vestirme } \\
\text { de acuerdo a mi } \\
\text { cuerpo. De películas: } \\
\text { por mis actores } \\
\text { favoritos. De la ropa } \\
\text { y accesorios que usan } \\
\text { en mi familia, por mi } \\
\text { mamá, mis primas, } \\
\text { por mis amigos, } \\
\text { porque me gusta } \\
\text { como se visten, por la } \\
\text { música: me agrada la } \\
\text { forma de vestir } \\
\text { oscura, revistas: } \\
\text { ejemplos de moda. }\end{array}$ \\
\hline $\begin{array}{ll}\text { J26 } & \\
\text { Hombre } \\
\text { de } 14 \\
\text { años }\end{array}$ & $\begin{array}{l}\text { Para mí es la forma en que } \\
\text { se expresa una persona. }\end{array}$ & $\begin{array}{l}\text { Mis fotos de perfil deben ser } \\
\text { bellas, porque es donde saco } \\
\text { mi personalidad. Tienen que } \\
\text { tener naturaleza y no mucha }\end{array}$ & $\begin{array}{l}\text { Uso ropa colorida y que } \\
\text { demuestren felicidad y paz. } \\
\text { No uso muchos accesorios en } \\
\text { mis fotos, pero cuando lo }\end{array}$ & $\begin{array}{l}\text { En las fotos de perfil me } \\
\text { gusta demostrar seguridad, } \\
\text { mostrar momentos felices o } \\
\text { que quiera mostrar o si estoy }\end{array}$ & $\begin{array}{l}\text { De Facebook, de } \\
\text { películas, de videos } \\
\text { musicales, de lo que } \\
\text { usan mis amigos. }\end{array}$ \\
\hline
\end{tabular}




\begin{tabular}{|c|c|c|c|c|c|}
\hline & & $\begin{array}{l}\text { edición, ya que la verdadera } \\
\text { belleza es natural. }\end{array}$ & $\begin{array}{l}\text { hago busco cosas bonitas y } \\
\text { coloridas y que estén a la } \\
\text { moda. Yo a veces usaba la } \\
\text { aplicación de Snapchat para } \\
\text { adornar mis fotos, pero } \\
\text { físicamente no usaba ningún } \\
\text { accesorio. Usualmente no } \\
\text { suelo adoptar ninguna } \\
\text { posición en mis fotos, pero } \\
\text { suelo hacer mucho el signo de } \\
\text { paz porque creo que } \\
\text { demuestra confianza y } \\
\text { orgullo. }\end{array}$ & $\begin{array}{l}\text { feliz, lo importante para mi } \\
\text { es sentirme bien conmigo } \\
\text { mismo, porque es natural y } \\
\text { es bueno sentirse bien con } \\
\text { uno mismo. No me importa } \\
\text { mucho si a otros les gustan } \\
\text { o no mis fotos, pero aun así } \\
\text { es agradable saber que a las } \\
\text { personas les gusta como } \\
\text { eres. }\end{array}$ & $\begin{array}{l}\text { Porque a la gente a } \\
\text { veces le gusta lo que } \\
\text { otras personas hacen } \\
\text { y me gusta } \\
\text { "copiarme" un poco } \\
\text { de ellos, entre las } \\
\text { redes sociales miro } \\
\text { cómo se visten los } \\
\text { cantantes y personas } \\
\text { de la televisión. }\end{array}$ \\
\hline $\begin{array}{l}\text { J27 } \\
\text { Mujer } \\
\text { de } 14\end{array}$ & $\begin{array}{l}\text { Para mí la estética en las } \\
\text { fotos es mirarse y no mirar } \\
\text { tus imperfecciones si no lo } \\
\text { quieres mostrar a través de } \\
\text { ellas, sin importar lo } \\
\text { comenten y si les gusta. }\end{array}$ & $\begin{array}{l}\text { No considero que las fotos } \\
\text { tengan que ser bellas, sino } \\
\text { descriptivas de mi forma de } \\
\text { ser y mis caras y gestos me } \\
\text { den a conocer en cualquier } \\
\text { sitio. }\end{array}$ & $\begin{array}{l}\text { La sonrisa que esté cómoda } \\
\text { para que la vean. Uso gestos, } \\
\text { emojis. Accesorios con los } \\
\text { que me sienta cómoda con lo } \\
\text { que elijo y me sienta cool. } \\
\text { Aretes porque me gusta que } \\
\text { mis oídos estén adornados. } \\
\text { Balacas para que mi pelo } \\
\text { luzca con todo. Manillas: para } \\
\text { verme identificada con la } \\
\text { historia de estas manillas y } \\
\text { por cuántas personas pasaron } \\
\text { y que combinen con lo que } \\
\text { uso y que signifiquen algo } \\
\text { para mí. A veces salgo con la } \\
\text { lengua afuera, con la mano en } \\
\text { la cintura sonriendo, con la } \\
\text { lengua afuera porque estoy } \\
\text { aburrida, mano en la cintura } \\
\text { significa que estoy jugando y } \\
\text { me canso. Sonreír porque ese } \\
\text { día me puse algo bueno o } \\
\text { viajé. }\end{array}$ & $\begin{array}{l}\text { Me gusta expresar } \\
\text { momentos que signifiquen } \\
\text { algo para mí, mostrar cosas } \\
\text { que yo aprecie en mis fotos } \\
\text { de perfil. Me encanta que } \\
\text { las demás personas me vean } \\
\text { diferente en cada foto. La } \\
\text { belleza solo está en lo que } \\
\text { tiene imperfecciones, } \\
\text { problemas, a esto se le llama } \\
\text { belleza de la vida. }\end{array}$ & $\begin{array}{l}\text { Del tipo de ropa que } \\
\text { usan en mi familia y } \\
\text { mi grupo de amigos, } \\
\text { de las revistas, } \\
\text { porque me gustan sus } \\
\text { colores y estilos, las } \\
\text { tendencias que } \\
\text { buscan para verse } \\
\text { mejor, de la } \\
\text { publicidad porque me } \\
\text { hacen ver a la moda y } \\
\text { con más onda y } \\
\text { porque me gusta } \\
\text { siempre andar al día } \\
\text { con las nuevas } \\
\text { modas. }\end{array}$ \\
\hline $\mathrm{J} 28$ & Para mí es todo lo que nos & Las fotos que subo deben ser & En las fotos que me he & Me ha & De la televisión: por \\
\hline
\end{tabular}




\begin{tabular}{|c|c|c|c|c|c|}
\hline \begin{tabular}{ll}
\multicolumn{2}{c}{ Hombre } \\
de 15 \\
años
\end{tabular} & $\begin{array}{lll}\text { agrada } & \text { o } & \text { parece } \\
\text { interesante. } & & \end{array}$ & $\begin{array}{l}\text { bellas ya que nos interesa es } \\
\text { que la gente se asombre de } \\
\text { esa foto. Las condiciones que } \\
\text { debe tener es la claridad, filtro } \\
\text { y pose. }\end{array}$ & $\begin{array}{l}\text { tomado he buscado elegante o } \\
\text { deportiva. Uso gafas o } \\
\text { auriculares ya que esto hace } \\
\text { que la gente se interese más } \\
\text { por la foto, también uso } \\
\text { gorras, uso estos ya que } \\
\text { pienso que se verá bien y la } \\
\text { foto será cool. Hago poses } \\
\text { con la cara o manos pues a los } \\
\text { demás también les funciona } \\
\text { esto. El pulgar levantado: de } \\
\text { alguna forma digo que estoy } \\
\text { contento. De medio lado: lo } \\
\text { hago para verme serio. }\end{array}$ & $\begin{array}{l}\text { interesante en las fotos de } \\
\text { perfil y diferente. A veces } \\
\text { finjo una sonrisa así no } \\
\text { quiera sonreír. Me gusta } \\
\text { verme cool, a veces un poco } \\
\text { mayor o malo o para } \\
\text { recordar momentos alegres } \\
\text { como con mi primo, que es } \\
\text { como un hermano para mí. }\end{array}$ & $\begin{array}{l}\text { los famoso que se } \\
\text { ven bien. } \\
\text { Internet: es la moda. } \\
\text { Películas: se ven } \\
\text { cool. Amigos: para } \\
\text { verme interesante. } \\
\text { Música: porque es } \\
\text { genial e interesante. } \\
\text { De actores que salen } \\
\text { En la TV, YouTube, } \\
\text { red social y películas, } \\
\text { el actor o el que } \\
\text { aparecía se veía bien } \\
\text { para los demás. De } \\
\text { Facebook: } \\
\text { personas conseguían } \\
\text { likes. De la } \\
\text { publicidad: el modelo } \\
\text { con esa pose se veía } \\
\text { agradable para los } \\
\text { demás. }\end{array}$ \\
\hline $\begin{array}{l}\text { J29 } \\
\text { Mujer } \\
\text { de } 15 \\
\text { años }\end{array}$ & $\begin{array}{l}\text { Es ser sincero con uno } \\
\text { mismo y no mentirse. } \\
\text { Aquello con lo que uno } \\
\text { pueda sentirse } \\
\text { identificado. (otro sentido } \\
\text { de lo estético, ojo) }\end{array}$ & $\begin{array}{l}\text { Según mi opinión, lo primero } \\
\text { o lo más esencial, sería el } \\
\text { fondo ya que yo puedo estar } \\
\text { bella en la foto, pero puedo } \\
\text { estar en el basurero, lo } \\
\text { segundo, el filtro, lo tercero la } \\
\text { ropa y lo último el marco. }\end{array}$ & $\begin{array}{l}\text { La mayoría de veces salgo } \\
\text { con ropa de particular y otras } \\
\text { con el uniforme del colegio. } \\
\text { No uso muchos accesorios } \\
\text { porque ya es mucha } \\
\text { exageración en la foto, porque } \\
\text { también uso, pero muy poco } \\
\text { como aretes y collares, porque } \\
\text { me veo mejor. Uso posturas y } \\
\text { estos porque me hacen sentir } \\
\text { famosa o como una estrella y } \\
\text { para verme más bella. } \\
\text { También uso el signo de la } \\
\text { paz: por la paz mundial. Pico } \\
\text { de pato: por coquetear. } \\
\text { Respecto a la postura o seña }\end{array}$ & $\begin{array}{l}\text { Me gusta aparecer mucho } \\
\text { con mi mamá. Le pongo } \\
\text { marcos luminosos para que } \\
\text { llamen la atención o salir } \\
\text { con mis amigas en donde } \\
\text { me vea bien y esté haciendo } \\
\text { algo importante en ella y me } \\
\text { encanta. }\end{array}$ & $\begin{array}{l}\text { De mis amigos, } \\
\text { porque yo diría que } \\
\text { me veo a la moda, del } \\
\text { tipo de ropa que usan } \\
\text { en mi familia, porque } \\
\text { me la han heredado y } \\
\text { me gusta. }\end{array}$ \\
\hline
\end{tabular}




\begin{tabular}{|c|c|c|c|c|c|}
\hline & & & $\begin{array}{l}\text { que haga mi estado físico, } \\
\text { mente y emocionalmente }\end{array}$ & & \\
\hline $\begin{array}{l}\text { J30 } \\
\text { Hombre } \\
\text { de } \quad 15 \\
\text { años }\end{array}$ & $\begin{array}{l}\text { Es un buen cuerpo, buena } \\
\text { cara y lo bonita que es la } \\
\text { persona. }\end{array}$ & $\begin{array}{l}\text { Las fotos tienen que ser } \\
\text { bonitas para que les gusten a } \\
\text { algunas personas y por lucir } \\
\text { más. }\end{array}$ & $\begin{array}{l}\text { Uso Jeans, camisas polo. Usos } \\
\text { accesorios como audífonos, } \\
\text { diademas, los utilizo para } \\
\text { sobresalir en la foto, porque } \\
\text { uno a veces queda mejor con } \\
\text { accesorio, eso pienso yo. } \\
\text { Hago posturas y gestos para } \\
\text { quedar mejor como sacar la } \\
\text { lengua, poner caras y así me } \\
\text { veo mejor y luzco más en la } \\
\text { foto. }\end{array}$ & $\begin{array}{l}\text { Me ha gustado vestirme } \\
\text { para las fotos de diferente } \\
\text { manera, a veces elegante, } \\
\text { casual cool, siendo creativo } \\
\text { y tener imaginación para } \\
\text { lucir bien y llamar la } \\
\text { atención, con gorras o } \\
\text { estando serio en las fotos. } \\
\text { Cuando no les gustan mis } \\
\text { fotos a otros, pues normal, } \\
\text { después de un tiempo me } \\
\text { tomo otra y mirar qué pasa. } \\
\text { No es muy importante eso } \\
\text { para mí, aunque algunas } \\
\text { veces nara agradar más }\end{array}$ & $\begin{array}{lr}\text { Miro a } & \text { gente } \\
\text { desconocida } & \text { a } \\
\text { personas de mi } \\
\text { familia para } & \text { saber } \\
\text { cómo tomarme } \\
\text { vestirme o } r \text { los } \\
\text { accesorios } & \text { para } \\
\text { ponerme, yo miro } \\
\text { como verme bien. }\end{array}$ \\
\hline
\end{tabular}


11.2 B. Anexo: datos-grupo Focal-entrevista

\section{INSTITUCIÓN EDUCATIVA DISTRITAL FERNANDO GONZÁLEZ OCHOA \\ LOCALIDAD DE USME \\ GRADO OCTAVO J.M \\ GRUPO FOCAL}

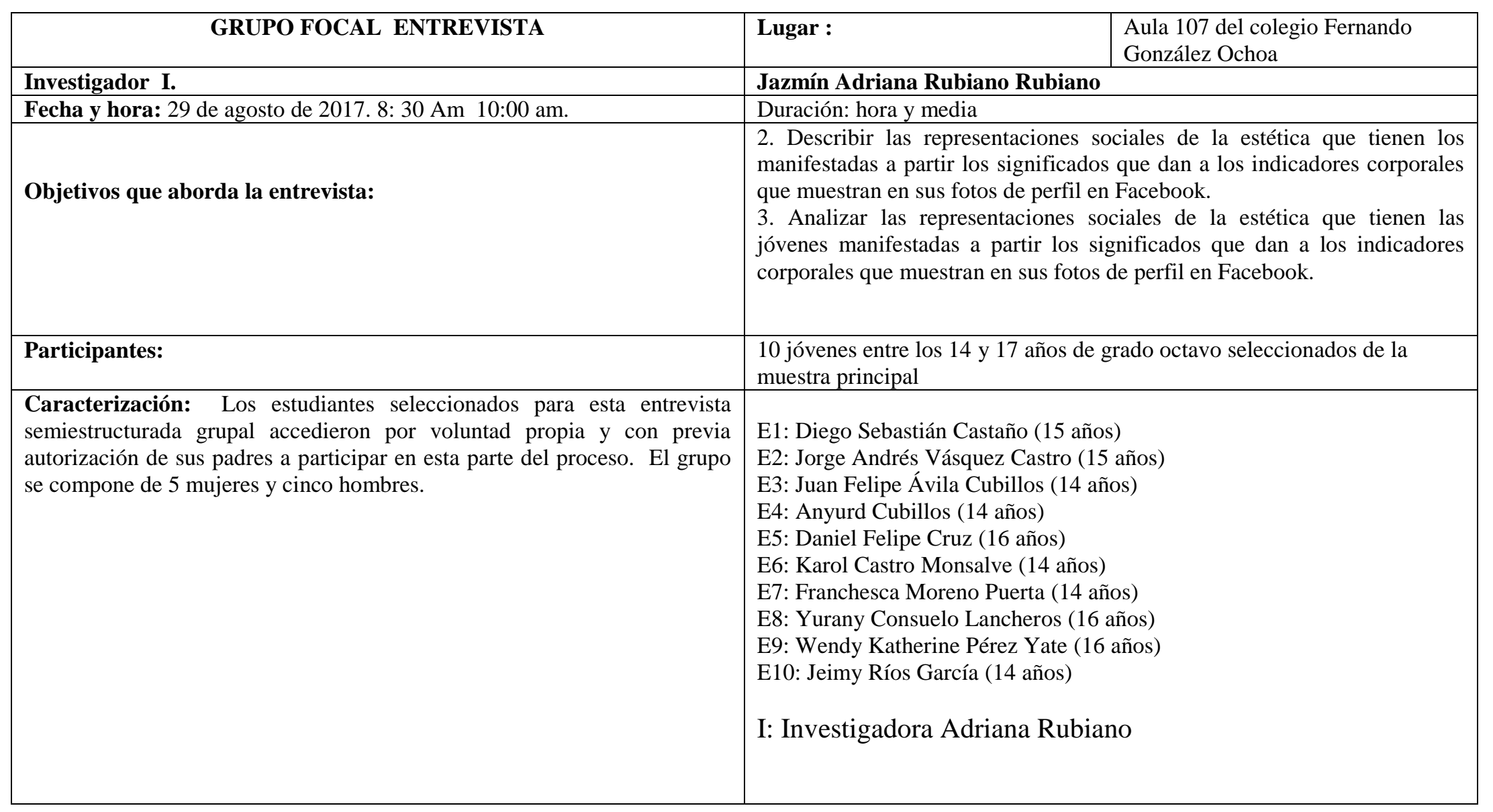


Procedimiento: La investigadora explica en primer lugar el objetivo de la entrevista. Después les comenta a los participantes que la actividad se llevará a cabo estilo conversación grupal y que cada uno irá respondiendo a las preguntas por turnos, de acuerdo a quien levante el mano primero. los jóvenes podían intervenir no solamente para contestar la pregunta formulada por el investigador, sino para apoyar, ampliar, refutar o contar alguna experiencia con relación a la pregunta abordad y a las respuestas de sus compañeros.

\section{Preguntas entrevista semiestructurada}

\begin{tabular}{|c|c|c|}
\hline $\begin{array}{l}\text { Número de } \\
\text { pregunta }\end{array}$ & Preguntas & $\begin{array}{l}\text { Categorías y subcategorías o aspectos } \\
\text { centrales a indagar }\end{array}$ \\
\hline \# 1 & $\begin{array}{l}\text { ¿Qué criterios tienes en cuenta para publicar una foto de perfil en Facebook con } \\
\text { relación a la ropa, accesorios y posturas corporales? }\end{array}$ & Todas las categorías y subcategorías $\left({ }^{31}\right)$ \\
\hline \# 2 & $\begin{array}{l}\text { ¿Qué motivaciones tienes para publicar fotos de perfil con los criterios de la } \\
\text { pregunta anterior? }\end{array}$ & Todas las categorías y subcategorías $\left({ }^{32}\right)$ \\
\hline \# 3 & $\begin{array}{l}\text { ¿Qué herramientas de la plataforma de Facebook, específicamente las } \\
\text { relacionadas con la foto de perfil, te permiten saber si tus fotos han gustado a los } \\
\text { demás? }\end{array}$ & $\begin{array}{l}\text { Aspectos contextuales de la plataforma y su } \\
\text { relación con las fotos de perfil de los jóvenes }\end{array}$ \\
\hline \# 4 & ¿ Cómo te afecta a ti la reacción de los demás frente a tus fotos de perfil? & $\begin{array}{l}\text { Categoría de reconocimiento. Subcategorías: } \\
\text { visibilidad, aceptación social, popularidad }\end{array}$ \\
\hline \# 5 & $\begin{array}{l}\text { ¿Qué tipo de ropa, accesorios y posturas corporales no consideras estéticas para } \\
\text { mostrar en tus fotos de perfil en Facebook? ¿Por qué? }\end{array}$ & Todas las categorías y subcategorías $\left({ }^{33}\right)$ \\
\hline \# 6 & $\begin{array}{l}\text { ¿Cómo ha sido tu experiencia personal en Facebook en relación a la forma en } \\
\text { que presentas tus fotos de perfil, específicamente a partir de la ropa, accesorios } \\
\text { y posturas corporales que muestras en ellas? }\end{array}$ & $\begin{array}{l}\text { Narrativas y aspectos biográficos de los } \\
\text { jóvenes en relación a sus representaciones } \\
\text { sociales sobre la estética }\end{array}$ \\
\hline \# 7 & $\begin{array}{l}\text { ¿Tienes un modelo a seguir cuando elaboras una foto de perfil en Facebook, } \\
\text { específicamente en relación con la ropa, accesorios y posturas corporales que } \\
\text { muestras en ellas? Explica ampliamente por qué. }\end{array}$ & $\begin{array}{l}\text { Aspectos socioculturales de las } \\
\text { representaciones sociales de los jóvenes de la } \\
\text { estética }\end{array}$ \\
\hline \# 8 & ¿Qué relación tiene la apariencia física que muestras en tus fotos de perfil en & Categoría: belleza. Subcategorías: apariencia \\
\hline
\end{tabular}

\footnotetext{
${ }^{31}$ La categorías y subcategorías se pueden revisar en la tabla 2.

${ }^{32}$ La categorías y subcategorías se pueden revisar en la tabla 2.

${ }^{33}$ La categorías y subcategorías se pueden revisar en la tabla 2.
} 


\begin{tabular}{|c|l|l|}
\hline & Facebook con la ropa, accesorios y posturas corporales que usas en ellas? & deseada, perfección. \\
\hline$\# \mathbf{9}$ & $\begin{array}{l}\text { ¿Crees que es importante tener alguna estrategia para lucir mejor en tus fotos de } \\
\text { perfil en Facebook, específicamente en relación a ropa, accesorios y posturas } \\
\text { corporales? ¿Por qué? }\end{array}$ & $\begin{array}{l}\text { Categoría: personalización. Subcategorías: } \\
\text { diferenciación, gusto, moda, creatividad, } \\
\text { estilo. }\end{array}$ \\
\hline \# 10 & $\begin{array}{l}\text { Si tienes una estrategia para lucir mejor en tus fotos de perfil ¿Cuál o cuáles son } \\
\text { esas estrategias? ¿Por qué consideras que puede(n) funcionar? }\end{array}$ & $\begin{array}{l}\text { Categoría: personalización. Subcategorías: } \\
\text { diferenciación, gusto, moda, creatividad, } \\
\text { estilo. }\end{array}$ \\
\hline
\end{tabular}

\section{Transcripción de la entrevista}

I. Buenos días muchachos. Gracias por haber aceptado la invitación para hacer parte de esta entrevista. Les pido el favor de que se pongan cómodos. Vamos a hacer un semicírculo con esas sillas de allá.

Jóvenes: Buenos días profe.

\section{I. ¿Dónde está Juan Felipe?}

E2. Está en el baño, que ya viene.

E3. Buenos días profe.

I. Buen día Juan Felipe. Te estábamos esperando. Bien muchachos, voy a explicarles cómo va a funcionar la entrevista. Como ustedes lo saben, hemos estado trabajando con el grupo del curso algunas actividades que tienen que ver con el Facebook y las fotos de perfil 
que ustedes publican allí, centrándonos en aquellas fotos que incluyen ropa, accesorios... ¿qué más elementos hemos trabajado con las fotos?

E2. Ummm lo de los gestos que uno hace o las posturas, como sacando la lengua o sonreír y otras que pusimos en ese cuadro...el primero que hicimos ahh y en las preguntas...

I. Exacto. También posturas corporales, como gestos y demás. Bien chicos, vamos a dar inicio a la entrevista. La mecánica será que yo les leo la pregunta y ustedes van contestando, si quieren en el orden en que se sentaron o de forma voluntaria. Si alguno quiere preguntar algo o comentar alguna respuesta de otro compañero, lo puede hacer, pero con el mayor respeto por las ideas de los demás y respetando la palabra... ¿de acuerdo?

Jóvenes: si profe. (Algunos hacen una señal con la cabeza en señal de asentimiento)

I. Muy bien, la primera pregunta es: ¿Qué criterios tienes en cuenta para publicar una foto de perfil en Facebook con relación a la ropa, accesorios y posturas corporales?

E10. Profe ... ¿qué quiere decir criterios...? 
I. Significa o es sinónimo de las condiciones que tú tienes en cuenta para hacer o decir algo, en este caso sería qué debería tener una foto de perfil en relación con la ropa, los accesorios, las posturas...cómo deberían ser para que tú decidas que son adecuados para mostrarlos en tus fotos... ¿me hice entender chicos?...

E.6 Ahhh ya, ya entendí.

I. Listo muchachos ¿quién va primero? están bastante tímidos ustedes hoy. Empecemos con Diego y así se va animando el resto...jejeje

E1. ¿Yo? ashhhhhh jaj aja me da pena... bueno listo. Profe pues para mí como lo importante es que lo que uno suba a Facebook es para ser libre y expresarse, porque nadie lo puede juzgar a uno, en muchos casos las fotos bellas son para enamorar a chicas...

Jóvenes: uuuuuuuyyyyy jajajjajajajajjajaja

I. Bueno chicos, dejemos que Diego siga...

E1. Sí, si no, no hablo. Bueno, también enamorar a chicos jajaj, las niñas ¿no? Jajaj. Para verse guapo

I. Bueno Diego, y con respecto a la ropa, a las posturas corporales... ¿qué tienes en cuenta en tus fotos?

E1. Que tengan buen gesto, que la ropa esté bien... o sea que sea bonita, tener buenos accesorios, buen fondo...umm bueno a veces el fondo no es así que importe tanto, pero tratar de que no tenga mal fondo. 
I. Okey....ahora una niña... ¿quién quiere responder la pregunta...?

(La estudiante karol Castro levanta la mano)

E1. Bueno tú Karol... ¿qué contestas?

E6. Profe, para mi tiene que tener una mirada bonita, que el cabello de uno esté bien organizadito y que el fondo está bien iluminado, eso sí, si no queda re fea porque queda oscura.

I. Es decir, que para ti los fondos e iluminación también pueden embellecer o afectar negativamente la foto...

E6. Si profe, una vez me tomé una foto y yo consideraba que me había quedado bien, pero luego quedó toda oscura y fea, pero bueno menos mal existe Sweet Selfie y todo arreglado jejeej

I. ¿Podrías explicarnos qué es eso de Sweet Selfie? Juan Felipe por fa, escuchemos a los compañeros.

E6. Profe es una aplicación que le ayuda a uno a poner más bonitas las fotos, es como para arreglarlas ¿sí? Uno le puede poner fondos, le arregla la luz, hasta le puede poner orejas de conejo, resto de cosas y las fotos quedan re cool con eso.

E9. Umm... pero a mí me parece más bacana la de G612, tiene como más cosas para hacerle a las fotos diferentes...

E6. Nooo, pero la de Sweet Selfie tiene más filtros para belleza. 
I. Bueno, ven Wendy aprovechemos tu intervención...podrías responder tú la pregunta uno por favor...

E9. Profe jeje me podrías repetir la pregunta...

I. Wendy, es sobre los criterios que tú tienes en cuenta para elegir una foto de perfil, pero en conexión con la ropa, las posturas, los accesorios que usas ...

E9. Yo considero que si uno va a salir mal en una foto que mucha gente va a mirar... yo no saldría mal arreglada o despeinada ya que esa foto es tu perfil y es como la gente te va a ver en las redes...

I. Bueno Wendy... ¿y qué tipo de ropa, accesorios, posturas, gestos, usas en esas fotos?...

E9. Bueno, eso depende del momento en el que esté, aunque casi siempre uso la apretada...la ropa jajaj o la suelta que sea decente y me vea bien con ella. Casi siempre me gusta estar a la moda y uno aprende a usar la ropa para cualquier ocasión. Para mí una foto de perfil linda es que tenga unos buenos fondos y que uno use una ropa linda y que lo haga sentir a uno cómodo. Queda bien si uno la sabe decorar y la edita bien. Ahh... el peinado también es importante, que los demás vean que uno tiene buen gusto.

I. ¿Sueles usar accesorios en tus fotos?

E9. Sí porque siento que me hacen ver más cool y se ven bien...ya que depende del accesorio que esté usando porque hay cosas que a uno no le quedan bien. A veces uso joyas, pañoletas, guantes...los guantes son porque siento que me veo ruda o loca jajajja. 
E2. Jjajajaja sobre todo loca jajajajajja

E9. Ay, ¡Cállese!, salte aquí mijo...

E1. Bueno. Vamos a tener cuidado con respetar todas las intervenciones.

I. Ya después de ti, Jorge Andrés nos va a contestar la pregunta ...vale Jorge...

\section{E2. Listo. De una.}

I. Wendy ¿Usas algún gesto o postura corporal en tus fotos de perfil?

E2. Si, a veces porque con las poses o señales que uno haga lo hacen ver coqueto... o serio de alguna manera particular. Me pongo en las fotos de lado o de frente o haciendo puchero, estas serían una como siendo coqueta y en la otra pareciendo triste y tierna a la vez, ahhh o sonriendo, esa es la más común ya que cualquiera sonríe así sea falsa o verdadera...

I. Gracias Wendy. Escuchemos ahora a Jorge.

E2. Bueno, yo creo que lo más importante es que a mí me guste la foto. A veces creo que las fotos deben ser bonitas y a veces no y pueden estar bien, tengan o no tengan filtros, puedo considerar bella siempre que mi sonrisa se vea bien la considero bella.

I. Jorge ... ¿usas algún tipo de accesorio, gesto, postura en tus fotos? 
E2. Sí. A veces me pongo gorras, son buenas cuando olvido algo me la pongo y así no me ven bien y no me preguntan en el colegio nada, ay, hay veces cojo y me tomo una foto desparche con la gorra y la subo si tengo datos.

I. Ummmm jajajaaj okey. Y las poses, posturas ¿tiendes a usarlas para tus fotos?

E2. Sí, porque si está una foto normal se va a ver aburrido y por eso es mejor estar cambiando.

I. ¿Cuáles gestos usas entonces?

E2: Uy...sonreír, que siempre tener una sonrisa, lentes porque se ven bien, bueno claro que ese no es gesto jajja, de medio lado porque es mejor para solo se vea una parte del cuerpo

I. ¿Por qué querrías que solo se viera una parte del cuerpo?

E2. Pues que se vea la parte buena, la que me gusta mostrar.

\section{A ver Yurani.}

E8. Siempre uso muchos fondos en mis fotos para que no sean como tan simples, también busco aplicaciones para poner orejas de animales tiernos o maquillaje que me haga resaltar la cara sobre todo como las de Snapchat

I. Bueno, gracias a los que participaron en esta pregunta. Esperaría que en las otras también pueda escuchar la voz de los que no se han pronunciado ¿Vale? Les voy a leer la segunda pregunta y vemos quién empieza. ¿Qué motivaciones tienes para publicar fotos de perfil con los 
criterios de la pregunta anterior?; es decir, si ya sabes cómo debe ser una foto de perfil de acuerdo a ropa, accesorios, etc., ¿qué tipo de cosas hacen que tú quieras mostrar en tus fotos ese tipo de cosas? Algún voluntario...

E10. Buenos días. Bueno para mí en la foto yo debo salir bien peinada, bien vestida, un buen gesto...lo que quiero es que me guste a mí la foto. Yo me arreglo y me visto no para que los demás opinen y si me critican no los escucho, porque a mí no me gusta opinar de las otras personas que, si están feos o si están lindos, no me gusta.

I. Es decir, que si te dan me gusta o no en tus fotos ¿no te interesa?

E10. Pues si les gusta bien, pues si no, me resbala, porque yo me peino para mí, me visto para mí, todo lo hago para mí. Me podría muy feliz por ellos me aceptan como soy, yo no le tengo que hacer arreglos a las fotos porque así soy yo.

I. Muchas gracias. ¿Alguien quiere opinar algo al respecto?

E9. Pero yo creo que a uno sí le gusta que le den muchos me gusta a las fotos, es mentira que a uno eso no le importe nada porque si no no mostraría las fotos. Yo por ejemplo publico una y, si veo que no les gusta a otros, pues la cambio y ya, ensayo con otras y miro a ver qué pasa.

E10. Con que me gusten a mi...

I. Tú Yurani que hace rato estás levantando la mano. 
E8. Pues yo creo que uno no lo hace solo por los demás...pero a uno si le gusta que a otros le gusten sus fotos. Para mí es importante porque me siento bien cuando dan likes o comentan cosas en buenos sentidos ...además, pues yo les pregunto a mis amigos si una ropa me queda bien o no y así aprendo a verme mejor en las fotos y no me parece malo.

I. Bueno. Vamos a continuar con la pregunta dos. Yurani, ¿puedes contestarla por favor?

E8. Ashhh ya me perdí ¿es sobre por qué uno las publica así?...

I. Es acerca de las motivaciones que tienes para publicar tus fotos con ciertos criterios o condiciones en relación con la ropa, accesorios, posturas...

E8. Ah bueno. Pues yo trato de escoger la foto más bella, pues uno escoge la mejor foto, la más linda que más le guste a uno. Yo creo que mi foto de perfil es bella no utilizando taaaantas cosas, es mejor poco y bonito, pues no tan poco...de acuerdo a como uno lo quiera, me gustan mucho las ombligueras o bustos.

I. y ¿Por qué crees que escoges la foto más linda para publicarla Yurani?

Pues es como para verme bella porque a mí me gusta lucirme mucho, me gusta llamar la atención usando aretes, labial para no verme tan pálida y cosas así.

I. Bueno y un chico que nos conteste a esta pregunta. ¿Qué opinas Anyurd? 
E4. A mí me gusta sacar mi personalidad en las fotos de perfil, por eso tienen que tener naturaleza y no estar tan editadas.

I. ¿Por qué crees que es importante que tus fotos reflejen tu personalidad?

E4. Porque si las fotos son bellas, deben expresar lo que es la persona.

I. Muy bien muchachos, vamos a abordar ahora la pregunta número tres. Nuevamente espero escuchar también a los que no han hablado, pues las ideas de todos ustedes son sumamente valiosas para esta investigación. Es esta: ¿Qué herramientas de la plataforma de Facebook, específicamente las relacionadas con la foto de perfil, te permiten saber si tus fotos han gustado a los demás?

E7. Yo profe.

I. Listo, dale Franchesca.

E7. En el Facebook está la parte para dar me gusta. Ahí uno puede saber si les gustaron o no las fotos a los amigos o ellos pueden escribir comentarios de las fotos de uno o uno de las de los amigos. A veces cuando ellos ponen me gusta es agradable, pero cuando escriben algo feo uno se siente mal porque le daña a uno como la autoestima.

I. ¿Por qué crees que puede dañar tu autoestima?

E7. Porque hay gente muy pasada y así uno no le haiga hecho nada, le escriben a uno cosas feas.

I. ¿Qué haces cuando eso pasa? 
E7: pues a veces los borro y ya pero no me gusta.

\section{Gracias Franchesca. A ver tú, Daniel.}

E5. Uno también puede bloquear los comentarios. Si a uno no le gusta alguno que le hicieron.

I. ¿Cómo reaccionas tú cuando te escriben algún comentario en esta opción que da Facebook?

E5. Depende, si me doy cuenta de que estoy haciendo algo malo o que no me parece, bueno...lo elimino, pero si estoy a gusto con ella, pues bloqueo los comentarios.

I. okey. Muchas gracias. Alguien más quiere decir algo frente a esta pregunta...dime Karol

E6. Pues que la foto de perfil es pública, o sea que uno no le puede poner privacidad ni nada...entonces debe ser muy linda y llamar la atención, porque así uno no quiera todos las van a ver.

I. Gracias Karol... ¿alguien más? Bueno. Les leeré la pregunta número cuatro ahora: ¿Cómo te afecta a ti la reacción de los demás frente a tus fotos de perfil?, bueno, muchachos, creo que sin proponérnoslo la discusión ya había abordado esta pregunta, sin embargo, si alguien más quiere agregar algo...puede hacerlo antes de pasar a la pregunta cinco. Listo, dime Karol

E6. Pues cuando me hacen comentarios buenos sobre mis fotos, a mí me da mucha alegría y sé que me están apoyando detrás de la pantalla.

I. Y cuando los comentarios no son tan favorables ¿qué haces? 
E6 Pues los borraría o haría un comentario al respecto. A veces cuando publico una foto y mis amigos no me dan tantos likes o la ignoran el cambio inmediatamente porque eso quiere decir que la foto no impactó tanto...o sea que no les gustó tanto. Entonces me tomo una mejor.

I. Bueno, alguien más...

E7. Para mí eso no es tan importante, porque siempre que subo una foto, no es para satisfacer a los demás, siempre mirando entorno de lo que vivo y quiero.

E6. Pero si es así, entonces usted saldría despeinada o fea y yo creo que uno se preocupa por salir bien ¿o no?

E7. Yo creo que lo bonito también está en lo que tiene imperfecciones, no todo tiene que salir perfecto o no sería natural.

E6. Pero uno busca que la foto quede bonita o si no me va a decir que usted iría y se tomaría una foto en un basurero...uno se toma la foto según lo que a uno lo identifica, así sea por ejemplo un meme o unos peluches, ya que aquello puede uno sentirse identificado de alguna forma...

E7. Eso del basurero ya es una exageración. Para mí la belleza es mirarse y no mirar tanto tus imperfecciones sin importar lo comenten y si les gusta.

I. Bueno chicas, gracias por esas intervenciones tan valiosas. Vamos a pasar por cuestiones de tiempo a la siguiente pregunta ¿les parece? Va así: ¿Qué tipo de ropa, accesorios y posturas corporales no consideras estéticas para mostrar en tus fotos de perfil en Facebook? ¿Por qué? Dime Yurani. 
E8. Pues todo está bien, pero que no se excedan mostrando mucho su cuerpo.

E7. Sí, estoy de acuerdo...para mi todo tipo de ropa es válida, menos cuando niñas de mi edad salen a mostrar su cuerpo en ropa interior, casi desnudas ahh o el maquillaje, no me gusta porque algunas veces cuando son adultas su piel envejece más rápido, tampoco me gustan algunos gestos que hacen en canciones de reggaetón, como gestos sexuales, poses insinuantes...

I. Gracias Franchesca, ¿alguien más?

E7. A mí me parece que las ombligueras, los escotes grandes, chores, faldas no es agradable o collares muy grandes o pañoletas uy...o esa boca de pato o la cámara hacia abajo. La boca de pato es fea para mí y la cámara hacia abajo lo hace a uno ver gordo.

E8. Pues yo creo que las ombligueras pueden ser bonitas depende del cuerpo que uno tenga y lo más importante es que le guste a uno...pues cada uno hace sus posturas como quiere, o puede que se copeen, como yo a veces jajajaj

I. Bueno me gustaría escuchar a un chico al respecto de esta pregunta... ¿qué piensas tú Diego?

E1. Pues...en este momento no sabría decirles cuáles accesorios se ven mal para una foto, pero me parece que son feas las camisetas de muñecos infantiles o que no sea importante, porque eso es ya solo para los bebés...ummm me parece muy estúpido lo de las posturas y gestos que hacen las niñas para una foto...ya eso es muy ficti, que besos, que posturas, nada de eso me gusta y sería bueno una postura normal y un gesto normal, esos sí es bacano, pero nada más según mi opinión, eso es lo que pienso... 
I. Muchas gracias Diego, súper completa tu respuesta. Vamos ahora con la pregunta número seis. Es esta: ¿Cómo ha sido tu experiencia personal en Facebook en relación a la forma en que presentas tus fotos de perfil, específicamente a partir de la ropa, accesorios y posturas corporales que muestras en ellas? ¿Quién quiere hablar? ¿Nadie? Vamos, que sea voluntario...Por fin jejeje. Dale Juan Felipe.

E3. Pues a mí me ha gustado siempre llamar mucho la atención con mis fotos. Siempre les gustan mucho mis fotos a mis amigos porque tienen buenos fondos y los gestos, gafas que me pongo me hacen ver serio o más alto...a veces salgo extendiendo los brazos, siempre me gusta pensar bien como puede ser la foto...si quiero verme pensativo bajo los ojos, si quiero verme serio me pongo de medio lado el cuerpo, siempre me gusta tener el mejor style y siento agradable hasta ahora porque a la gente les gusta lo que publico.

I. Muy bien Felipe, gracias por compartirnos cómo ha sido tu experiencia con las fotos de perfil...una niña que nos comente ahora su experiencia...

E9. Bueno pues a mí me ha gustado ponerles muchos filtros a mis fotos. Por ejemplo, tengo una de mis favoritas ya que estoy con mi madre en París como unas reinas, es un filtro ya que en un futuro llevaré a mi madre conmigo a París. En otras fotos me gusta salir con mi hermano menor, en una tenemos dos filtros... unas orejas de gato junto con los bigotes y el fondo y unos collares, felices ya que fuimos al centro.

I. Muchas gracias por compartirnos ese sueño, Wendy. ¿Alguien más desea compartir una experiencia personal? Okey, pasemos a la siguiente pregunta entonces... ¿Tienes un modelo a seguir cuando elaboras una foto de perfil en Facebook, específicamente en relación con la ropa, accesorios y posturas corporales que muestras en ellas? Explica ampliamente por qué. A ver...quién levantó la mano por ahí...Karol, dime. 
E6. Pues a mí me gusta mirar actrices muy bonitas y me gusta su forma de vestirsen. O miro a los youtubers porque me agrada la forma de versen o miro la página de Internet porque salen muchos consejos de cómo vestirse uno de acuerdo al cuerpo que tenga. También miro a mis actores de las películas que me han gustado, a mis amigos...porque me gusta como se visten, o de la música y ummmm que más...ummm ah y de revistas profe, que muestran muchos ejemplos de moda.

I. Muchas gracias. A ver...Franchesca, estabas levantando la mano...

E7. Sí profe. No me ignore jajajja. Bueno, yo sigo más es el tipo de ropa que usan en mi familia y mis amigos y de las revistas...a veces de los comerciales porque me hacen ver qué está de moda, a mí me gusta siempre andar al día con las modas...de Facebook también porque hay gente que vemos que les gusta siempre mostrar algo nuevo y mi familia es porque les gusta describirse como personas muy relajadas, felices, inquietas...

I. Muchas gracias y un chico que me ayude a responder esta pregunta...Daniel...tú que andas tan calladito jejeje.

E5. Está bien. Profe, yo creo que uno debe tener su estilo propio en cuanto al tema de la ropa y esas cosas... a veces me influencio de la televisión porque aparecen varios personajes que admiro y me gusta como se visten, pero nada más.

I. Muchas gracias. Vamos muchachos con la pregunta que sigue y es: ¿Qué relación tiene la apariencia física que muestras en tus fotos de perfil en Facebook con la ropa, accesorios y posturas corporales que usas en ellas? Creo que en algunas de las preguntas anteriores ustedes abordaron esta pregunta, pero si alguien quisiera agregar algo más, bienvenido sea...A ver Yurany: 
E8: Pues la relación es que con esos fondos, ropa, etc., puedo estar más bella.

\section{Listo, a ver qué dices Juan Felipe...}

E3. Pues yo uso todos esos fondos, gestos y ropa bonita para que la gente tenga un buen punto de vista de uno porque se ve bien y para que a las personas les guste y les llame la atención.

I. ¿Qué piensas de esta pregunta Jorge?

E2 Pues la apariencia física debe ser bella en las fotos y otras veces no y sobre todo los filtros le puede ayudar a uno para la belleza, si uno la edita bien se va a ver mejor.

\section{Diego...}

E1. Si usos accesorios y ropa original es para lucir bien en la foto o si sonrió, sin parecerme a nadie, pues yo me visto original...no me gusta tener que parecerme a nadie.

Bueno muchachos, ya nos queda poco tiempo. Vamos a abordar la pregunta que sigue, que es: ¿Crees que es importante tener alguna estrategia para lucir mejor en tus fotos de perfil en Facebook, específicamente en relación a ropa, accesorios y posturas corporales? ¿Por qué? Anyurd, tú que has estado un poquito callado hace rato... ¿podrías contestar la pregunta, por favor? 
E4. Claro profe. Pues sí no sé si es estrategia, pero a veces me gusta lo que otras personas hacen y me gusta parecerme a ellos un poco, como que me copio ...algo de ellos...miro en las redes sociales cómo se visten los cantantes y personas de la televisión y los sigo. No es que le ponga muchos accesorios a mis fotos, pero cuando lo hago busco cosas bien bonitas, coloridas y que estén de moda.

E1. ¿Y por qué los sigues?

E4. Porque se ven bien y quiero verme bien también.

E1. Gracias Anyurd. Bueno, ¿alguien más? Dime ...

E9: Como la otra vez que estábamos hablando...creo que una foto de perfil es estética cuando uno ha pensado muy bien en qué fondos le va a poner. Ahí toca saber cómo cuadrarla porque si no uno se la tira jjajajjana. La puede dejar peor de lo que estaba. En internet hay resto de aplicaciones, yo la que más uso es la de G612 porque me deja ponerle mi estilo, cambiar la iluminación, me puedo poner aretes ...lo que quiera y siempre les gustan mucho mis fotos a mis amigos por eso. Esa sería como mi estrategia profe.

I. Muy bien, muchas gracias... ¿Alguien más?

E6. Si, yo Una foto es bonita si uno la planea bien. Toca ser muy creativos con los fondos y que la ropa y accesorios combinen, si no se ve muy simple la foto y no queda igual que si uno la planea.

I. Gracias Karol. Vamos a abordar la última pregunta que está muy conectada con la anterior y es: Si tienes una estrategia para lucir mejor en tus fotos de perfil ¿Cuál o cuáles son esas estrategias? ¿Por qué consideras que puede(n) funcionar? Creo que algunos de los que hablaron en la pregunta 
anterior, ya abordaron algunos aspectos de esta, pero me gustaría que se enfoquen en decirme no solo la estrategia o estrategias que puedan tener, sino por qué creen que puede o no funcionar... ¿listo? A ver, Yurani.

E8. Pues profe, creo que mi estrategia es usar fondos lindos, labial, poses que yo crea que se me pueden ver bien, ponerme ropa linda como ombligueras y sacos bonitos como dije antes...creo que es importante pensar bien las fotos, algunas una se las toma un poco desprevenida y no salen igual y creo que puede funcionar, además porque los amigos le dicen a uno si quedo bien o no o uno mismo se da cuenta.

I. Muy bien, muchas gracias. A ver Juan Felipe, tú quieres hablar.

E3. A mí me gusta que mis fondos sean diferentes, hacer posturas interesantes dependiendo de lo que yo quiera que la foto exprese, por ejemplo, si quiero verme divertido, entonces la tomo saltando o pensativo entonces pongo los ojos hacia abajo. Creo que si funciona la estrategia porque veo que a la gente le gusta ya que me veo mejor y me gusta y puedo llamar la atención de las personas.

Bueno muchachos, les agradezco muchísimo el haber participado en esta entrevista grupal, que es muy valiosa para la investigación que estoy realizando. Vamos a descanso. Que les vaya de lo mejor. 


\subsection{Anexo. Diarios de campo}

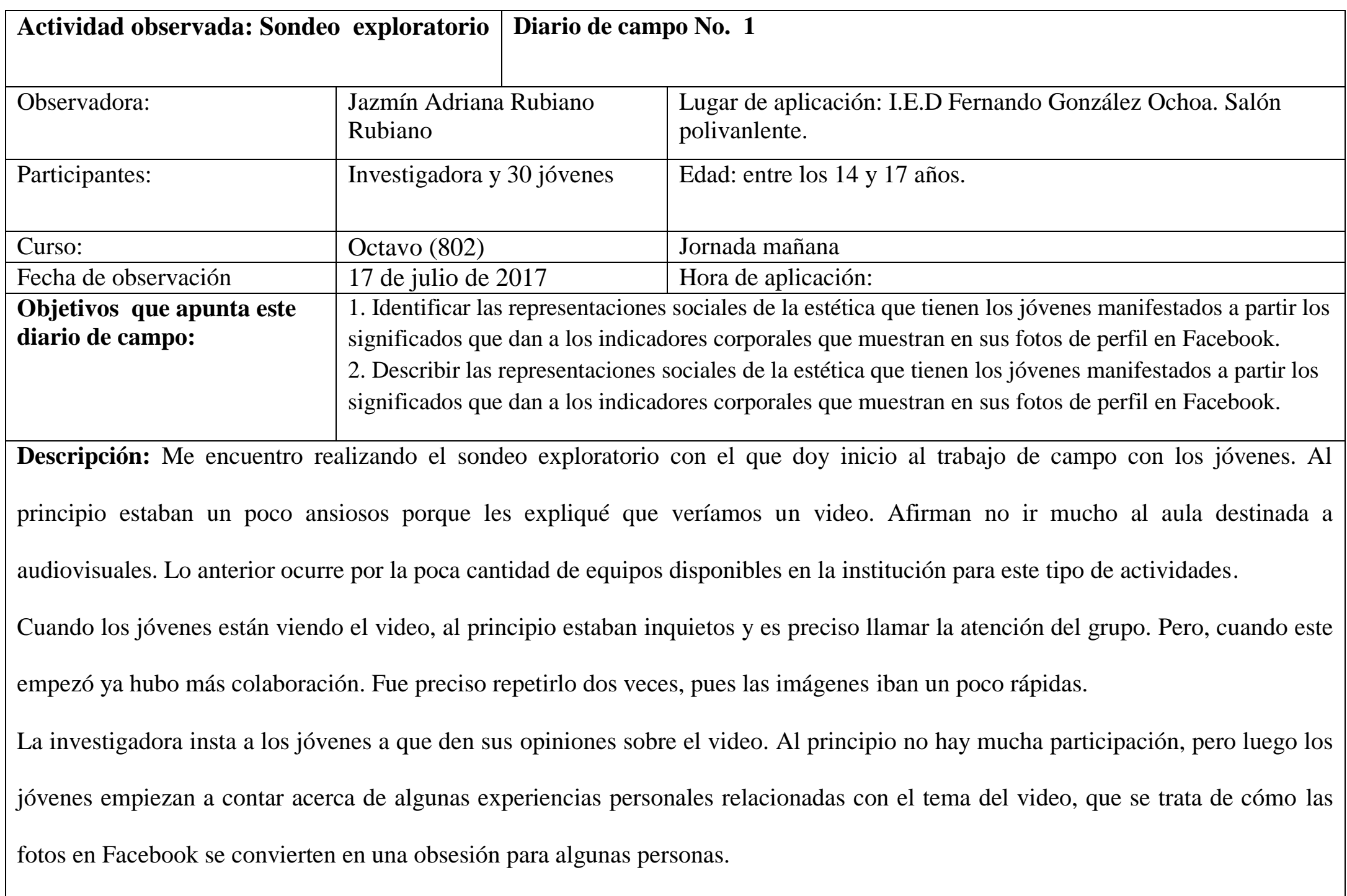




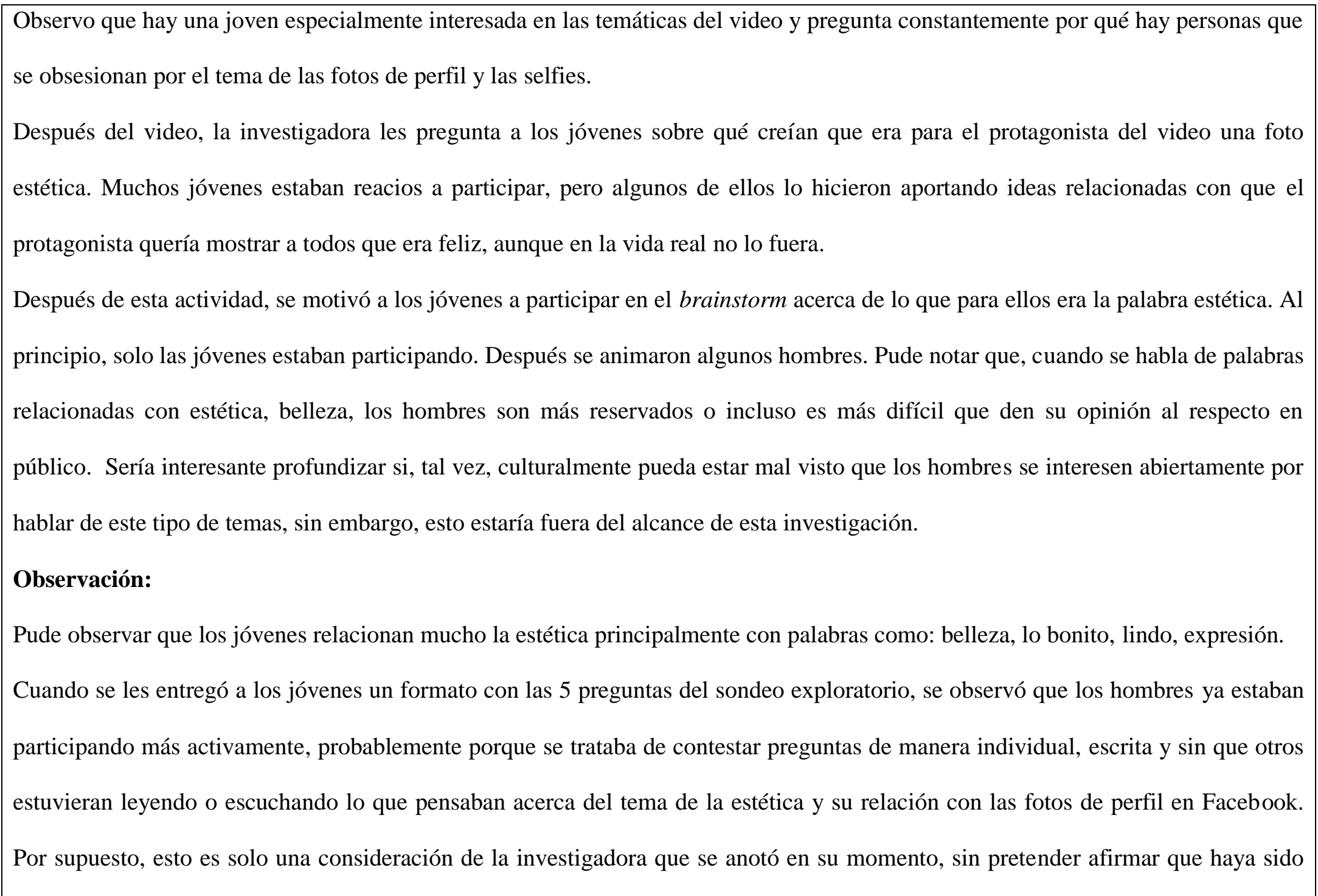


exactamente por eso.

\begin{tabular}{|l|l|l|}
\hline \multicolumn{2}{|c|}{$\begin{array}{c}\text { Actividad observada: Taller. } \\
\text { Instrumento aplicado \# } 2 \text { cuadro de } \\
\text { elementos significativos }\end{array}$} & Diario de campo No. 2 \\
\hline Observadora: & $\begin{array}{l}\text { Jazmín Adriana Rubiano } \\
\text { Rubiano }\end{array}$ & Lugar de aplicación: I.E.D Fernando González Ochoa. Salón 107. \\
\hline Participantes: & Investigadora y 30 jóvenes & Edad: entre los 14 y 17 años. \\
\hline Curso: & Octavo (802) & Jornada mañana \\
\hline Fecha de observación & 1 de agosto de 2017 & Hora de aplicación: 8:10 am \\
\hline $\begin{array}{l}\text { Objetivos que apunta este } \\
\text { diario de campo: }\end{array}$ & $\begin{array}{l}\text { 1. Identificar las representaciones sociales de la estética que tienen los jóvenes manifestados a partir los } \\
\text { significados que dan a los indicadores corporales que muestran en sus fotos de perfil en Facebook. } \\
\text { 2. Describir las representaciones sociales de la estética que tienen los jóvenes manifestados a partir los } \\
\text { significados que dan a los indicadores corporales que muestran en sus fotos de perfil en Facebook. }\end{array}$ \\
\hline $\begin{array}{l}\text { Descripción: Me encuentro con los jóvenes con quienes se está realizando la investigación. Se les había pedido que llevaran para } \\
\text { esta sesión un mínimo de 10 fotografías de sus perfiles de Facebook, para realizar la actividad con el cuadro de elementos }\end{array}$ \\
$\begin{array}{l}\text { significativos. Esta consistía en observar cada una de sus propias fotografías y encontrar qué elementos consideraban más } \\
\text { importantes en relación a la ropa, accesorios y posturas corporales que mostraban en ellas. Se observa cómo las jóvenes están más }\end{array}$ \\
\hline
\end{tabular}


interesadas en la actividad y llevaron el material requerido en mayor proporción que en el caso de los hombres. También noto que las mujeres escriben más detalladamente los datos que los hombres, quienes escriben freses menos elaboradas y terminan primero la actividad que muchas de ellas. Las mujeres, por su parte, mientras están realizando la actividad, en ocasiones comentan sus fotos con otras chicas, mientras los muchachos prefieren hacerlo solos.

\section{Observación:}

Es posible que en el contexto cultural en el que se desenvuelven los jóvenes, sea más socialmente aceptado que las mujeres se entusiasmen más con las fotos y comenten cómo lucen en ellas en público, que en el caso de los hombres. Siendo esta una posibilidad, que, sin embargo, no está sustentada con pruebas contundentes.

\begin{tabular}{|l|l|l|}
\hline $\begin{array}{l}\text { Actividad observada: taller. } \\
\text { Instrumento: mapa semántico. }\end{array}$ & Diario de campo No. 3 \\
\hline Observadora: & $\begin{array}{l}\text { Jazmín Adriana Rubiano } \\
\text { Rubiano }\end{array}$ & Lugar de aplicación: I.E.D Fernando González Ochoa. Salón 107. \\
\hline Participantes: & Investigadora y 30 jóvenes & Edad: entre los 14 y 17 años. \\
\hline Curso: & Octavo (802) & Jornada mañana \\
\hline
\end{tabular}




\begin{tabular}{|c|c|c|}
\hline Fecha de observación & 15 de agosto de 2017 & Hora de aplicación: 8:15 am \\
\hline $\begin{array}{l}\text { Objetivos que apunta este } \\
\text { diario de campo: }\end{array}$ & \multicolumn{2}{|c|}{$\begin{array}{l}\text { 1. Identificar las representaciones sociales de la estética que tienen los jóvenes manifestados a partir los } \\
\text { significados que dan a los indicadores corporales que muestran en sus fotos de perfil en Facebook. } \\
\text { 2. Describir las representaciones sociales de la estética que tienen los jóvenes manifestados a partir los } \\
\text { significados que dan a los indicadores corporales que muestran en sus fotos de perfil en Facebook. }\end{array}$} \\
\hline \multicolumn{3}{|l|}{ Descripción: } \\
\hline \multicolumn{3}{|c|}{ En esta ocasión, se está aplicando el instrumento número dos (mapa semántico). Se trata de que los jóvenes completen un modelo de } \\
\hline \multicolumn{2}{|c|}{ mapa semántico que la investigadora le entregó a cada uno, de acuerdo a los elementos más importantes que encuentren en relación } & uerdo a los elementos más importantes que encuentren en relación \\
\hline \multicolumn{3}{|c|}{ a la estética, pero vinculados con la ropa, accesorios y posturas corporales que muestran en sus fotos de perfil. Se observa cómo para } \\
\hline \multicolumn{3}{|c|}{ los jóvenes en general, resulta un tanto complicado condensar sus ideas en conceptos, por eso, pese a la indicación de agregar solo } \\
\hline \multicolumn{3}{|c|}{ palabras, algunos incluían frases. En general, los jóvenes realizaron el taller con buena disposición. Algunos de ellos se remitieron a } \\
\hline \multicolumn{3}{|c|}{ observar nuevamente las fotos de perfil que había llevado impresas desde la sesión anterior. } \\
\hline \multicolumn{3}{|c|}{ Observación: nuevamente los hombres son más concretos en relación al número de conceptos que incluyen, mientras las mujere } \\
\hline \multicolumn{3}{|c|}{ tienden a dar más detalles en cada aspecto que desarrollan en el mapa. } \\
\hline
\end{tabular}




\begin{tabular}{|c|c|c|}
\hline \multicolumn{2}{|c|}{$\begin{array}{l}\text { Actividad observada: entrevista } \\
\text { semiestructurada }\end{array}$} & Diario de campo No. 4 \\
\hline Observadora: & $\begin{array}{l}\text { Jazmín Adriana Rubiano } \\
\text { Rubiano }\end{array}$ & Lugar de aplicación: I.E.D Fernando González Ochoa. Salón 107. \\
\hline Participantes: & $\begin{array}{l}\text { Investigadora y } 10 \text { jóvenes ( } 5 \\
\text { hombres y } 5 \text { mujeres) }\end{array}$ & Edad: entre los 14 y 17 años. \\
\hline Curso: & Octavo (802) & Jornada mañana \\
\hline Fecha de observación & 29 de agosto de 2017 & Hora de aplicación: 8:10 am \\
\hline $\begin{array}{l}\text { Objetivos que apunta este } \\
\text { diario de campo: }\end{array}$ & \multicolumn{2}{|c|}{$\begin{array}{l}\text { 1. Identificar las representaciones sociales de la estética que tienen los jóvenes manifestados a partir los } \\
\text { significados que dan a los indicadores corporales que muestran en sus fotos de perfil en Facebook. } \\
\text { 2. Describir las representaciones sociales de la estética que tienen los jóvenes manifestados a partir los } \\
\text { significados que dan a los indicadores corporales que muestran en sus fotos de perfil en Facebook. }\end{array}$} \\
\hline \multicolumn{3}{|c|}{$\begin{array}{l}\text { Descripción: } \\
\text { Me encontré con } 10 \text { estudiantes del grupo general con quien estoy desarrollando la investigación. Los escogí a ellos, porque } \\
\text { mostraron más interés en continuar participando en la misma. Al principio observé que faltaba uno de los muchachos seleccionados, } \\
\text { pero luego apareció y se pudo dar inicio a la entrevista. Al principio, los jóvenes se mostraron algo tímidos a la hora de hablar en } \\
\text { público, pero poco a poco fue mejorando la participación. Aproximadamente participaban tres estudiantes por pregunta, lo que } \\
\text { permitió obtener un buen registro de datos por cada una, sin excederse en el tiempo disponible que se tenía para hacer la entrevista: } \\
\text { una hora y media, dado que los jóvenes estudiantes debían salir a descanso y después tenía clase de química. Las respuestas de los }\end{array}$} \\
\hline
\end{tabular}


jóvenes fueron fluyendo. Cada vez eran más profundas las respuestas que daban. Algunos de ellos, en especial algunos de los hombres se sentaron al principio con los brazos cruzados y no participaban mucho, pero después fueron integrándose más en la conversación. En dos ocasiones hubo dos discusiones en donde los puntos de vista se oponían entre sí, pero las jóvenes lograron exponer su punto de vista sin irrespetar a nadie. Solo en una ocasión una de las jóvenes le pidió de mala manera a uno de sus compañeros que se callara, por lo cual fue necesario llamar la atención y pedir respeto para cada intervención. En general, los jóvenes tuvieron una muy buena actitud.

\section{Observación:}

Se observa que, tanto en hombres como en mujeres, en especial los primeros, tiende a ser difícil hablar de una experiencia personal en relación a su apariencia física. Lo que se evidenció en la dificultad que se tuvo para lograr la participación de los estudiantes en la pregunta número 6. Probablemente, existan algunos elementos culturales que funcionen como inhibidores entre los jóvenes para hablar sobre temas como la propia apariencia física, sobre todo en público. Lo cual es una idea que surgió en el momento, sin que esto implique que se esté seguro de que esta sea la explicación. 


\subsection{Anexo. Instrumento 1. (Cuestionario de preguntas sondeo exploratorio)}

Responde las siguientes preguntas en el espacio vacío que tiene cada una debajo.

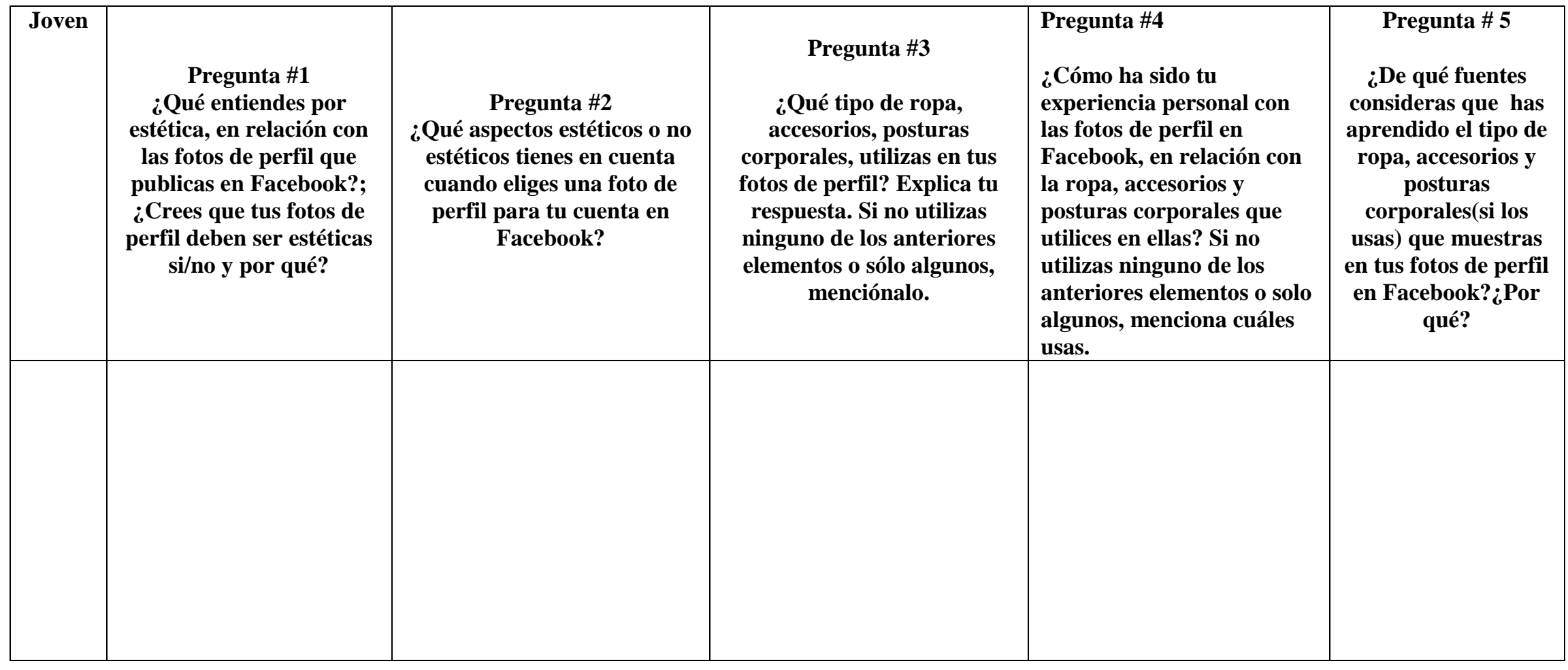


11.5 E. Anexo. Instrumento 2. Cuadro de elementos significativos.

\begin{tabular}{|c|c|c|c|c|c|c|c|c|c|c|}
\hline Foto \# & $\begin{array}{c}\text { Elementos } \\
\text { significativo } 1\end{array}$ & Significado & $\begin{array}{c}\text { Elemento } \\
\text { significativo } 2\end{array}$ & Significado & $\begin{array}{c}\text { Elementos } \\
\text { significativo } \\
3\end{array}$ & Significado & $\begin{array}{c}\text { Elementos } \\
\text { significati } \\
\text { vo } 4\end{array}$ & Significado & $\begin{array}{c}\text { Elementos } \\
\text { significativo } 5\end{array}$ & Significado \\
\hline 2 & & & & & & & & & & \\
\hline 3 & & & & & & & & & & \\
\hline 4 & & & & & & & & & & \\
\hline 5 & & & & & & & & & & \\
\hline 6 & & & & & & & & & & \\
\hline
\end{tabular}





\subsection{F. Anexo. Instrumento 3. Mapa semántico}

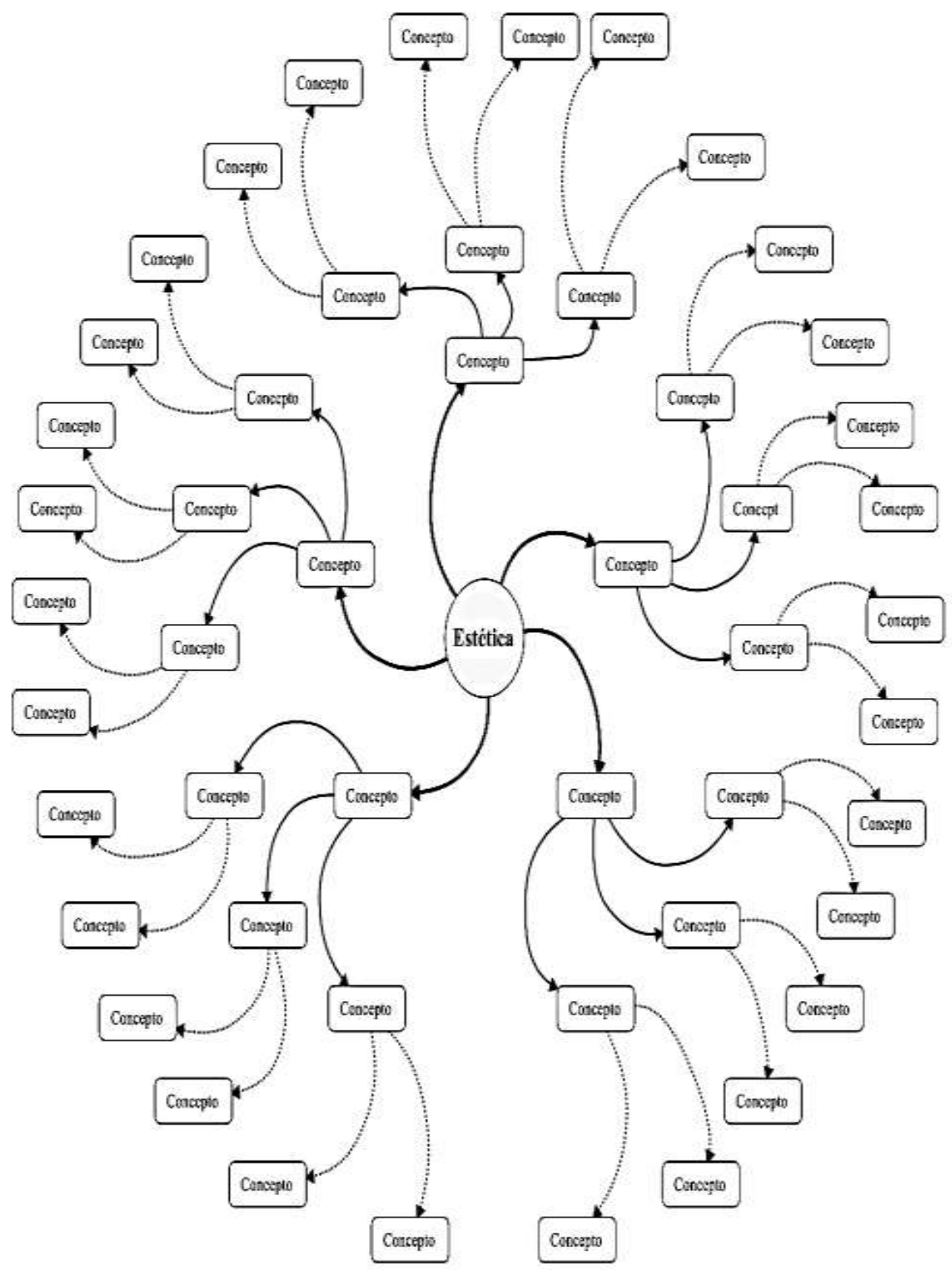




\subsection{G. Muestras de cuadros completados por jóvenes: instrumento 2}

(Mujer de 16 años)

\begin{tabular}{|c|c|c|c|c|c|c|c|c|c|c|}
\hline Foite कै & \begin{tabular}{|c|} 
Elenesates \\
significativo I
\end{tabular} & Signifieado & $\begin{array}{l}\text { Elemento } \\
\text { Nigeiflicative } 2\end{array}$ & Significade & \begin{tabular}{|c|}
$\begin{array}{c}\text { Kirmentins } \\
\text { Nigrificativo } \\
3\end{array}$ \\
\end{tabular} & $\overline{\text { Significade }}$ & \begin{tabular}{|c|} 
Eimentus \\
sigaifieas \\
ve 4
\end{tabular} & Stznificado & $\begin{array}{l}\text { Elemeatos } \\
\text { sigulificativo } 5\end{array}$ & Sirnifreade \\
\hline 1 & $\begin{array}{l}\text { Bluso } \\
\text { con } \\
\text { Fiores. }\end{array}$ & $\begin{array}{l}\text { La bluea } \\
\text { hace qu la } \\
\text { Foto terkgs } \\
\text { mas beileza }\end{array}$ & $\begin{array}{l}\text { la } \\
\text { Postura }\end{array}$ & 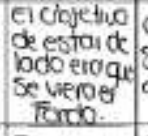 & $\begin{array}{l}\text { choqueio } \\
\text { serm- } \\
\text { cerroda }\end{array}$ & 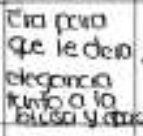 & $\begin{array}{l}\text { La } \\
\text { serriga } \\
\text { axita }\end{array}$ & $\begin{array}{l}\text { Qumadore } \\
\text { in trape de } \\
\text { alesino o } \\
\text { io roto. }\end{array}$ & & \\
\hline 2 & $\begin{array}{l}\text { La } \\
\text { expiesión } \\
\text { en la cono }\end{array}$ & $\begin{array}{l}\text { Quevo dorle } \\
\text { in toqe de } \\
\text { rarescia lo } \\
\text { roto }\end{array}$ & $\begin{array}{l}\text { El color } \\
\text { del } \\
\text { Peio. }\end{array}$ & $\begin{array}{l}\text { Era por el } \\
\text { controste } \\
\text { con ka } 162\end{array}$ & $\begin{array}{l}\text { la } \\
\text { boca } \\
\text { ctbierita. }\end{array}$ & $\begin{array}{l}\text { Querio que } \\
\text { b roto } \\
\text { quedoio } \\
\text { con ancio }\end{array}$ & $\begin{array}{l}\text { El } \\
\text { Peic de } \\
\text { locb }\end{array}$ & $\begin{array}{l}\text { Puia que } \\
\text { k diergun } \\
\text { toque dis- } \\
\text { tinto a iaruto. }\end{array}$ & & \\
\hline 3 & $\begin{array}{l}\text { las cejas } \\
\text { orriba }\end{array}$ & $\begin{array}{l}\text { Al sankir Se } \\
\text { cieo eso en- } \\
\text { Pesión. }\end{array}$ & $\begin{array}{l}\text { el } \\
\text { collar }\end{array}$ & $\begin{array}{l}\text { le doibo } \\
\text { mos prese- } \\
\text { ncopio } \\
\text { Tom. }\end{array}$ & $\begin{array}{l}10 \\
\text { senrnas }\end{array}$ & $\begin{array}{l}\text { Cra un, } \\
\text { goresion } \\
\text { de reindod }\end{array}$ & $\begin{array}{l}\text { el cercr } \\
\text { de mi } \\
\text { vesturard }\end{array}$ & 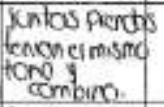 & & \\
\hline 4 & $\begin{array}{l}\text { La } \\
\text { Pose }\end{array}$ & 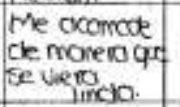 & $\begin{array}{l}\text { El } \\
\text { efecto }\end{array}$ & $\begin{array}{l}\text { Le dobcius } \\
\text { lon dostinta }\end{array}$ & 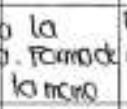 & $\begin{array}{l}\text { Derrcesilo } \\
\text { erenoncia }\end{array}$ & $\begin{array}{l}\text { to Tomo } \\
\text { de } \\
\text { Sontreir }\end{array}$ & $\begin{array}{l}\text { Le do mos } \\
\text { ielieidoda } \\
\text { la foto. }\end{array}$ & & \\
\hline 5 & $\begin{array}{l}\text { lo expresan } \\
\text { del beso }\end{array}$ & $\begin{array}{l}\text { Lo hre fouto } \\
\text { gre to foto } \\
\text { quedord } \\
\text { indo }\end{array}$ & $\begin{array}{l}\text { mi } \\
\text { Pexicicney } \\
\text { la Toto }\end{array}$ & $\begin{array}{l}\text { Al mererne } \\
\text { onas se } \\
\text { ue mejor } \\
\text { la Tato. }\end{array}$ & $\begin{array}{c}\text { la mano } \\
\text { en mi } \\
\text { cona }\end{array}$ & $\begin{array}{l}\text { Eno proro } \\
\text { oniegarle } \\
\text { moso lo } \\
\text { Rito. }\end{array}$ & $\begin{array}{l}\text { El } \\
\text { Deswo } \\
\text { de mi } \\
\text { miocto }\end{array}$ & 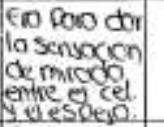 & & \\
\hline 6 & $\begin{array}{l}\text { Los } \\
\text { goras }\end{array}$ & 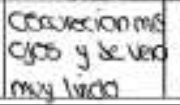 & $\begin{array}{l}\text { a Peo } \\
\text { liso }\end{array}$ & $\begin{array}{l}\text { Le diated } \\
\text { untogue } \\
\text { lindo (ick) }\end{array}$ & $\begin{array}{l}\text { la } \\
\text { sonmso }\end{array}$ & 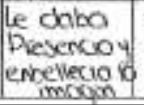 & $\begin{array}{l}\text { E1 } \\
\text { tonods } \\
\text { costio }\end{array}$ & $\left|\begin{array}{l}\text { Secres por } \\
\text { el enecto } \\
\text { de io } \\
\text { editosion }\end{array}\right|$ & & \\
\hline
\end{tabular}

\begin{tabular}{|c|c|c|c|c|c|c|c|c|c|c|}
\hline & $\begin{array}{l}\text { la } \\
\text { cadena. }\end{array}$ & $\begin{array}{l}\text { contrestabo } \\
\text { elcobor del } \\
\text { ardon neyro } \\
8 \text { g bus } \\
\text { blonco }\end{array}$ & $\begin{array}{l}\text { Mi } \\
\text { Pexición }\end{array}$ & $\begin{array}{l}\text { Hoco que } \\
\text { lo roto se } \\
\text { viero lndo }\end{array}$ & $\begin{array}{l}\text { la } \\
\text { maleh }\end{array}$ & $\begin{array}{l}\text { Demastrdua } \\
\text { ei lexor } \\
\text { dande } \\
\text { estoba }\end{array}$ & $\begin{array}{l}\text { EI } \\
\text { Peo re- } \\
\text { cojudo y } \\
\text { a los ioda }\end{array}$ & $\begin{array}{l}\text { Hocio ver } \\
\text { b roto } \\
\text { mas belic }\end{array}$ & & \\
\hline 7 & $\begin{array}{l}\text { (n) } \\
\text { Sonrriso } \\
\text { Finyda }\end{array}$ & $\begin{array}{l}\text { No ternid } \\
\text { gonas ce } \\
\text { Renme }\end{array}$ & $\begin{array}{l}\text { la } \\
\text { adularen } \\
\text { de pero }\end{array}$ & $\begin{array}{l}\text { de veic } \\
\text { indo yo } \\
\text { que estobo } \\
\text { Sobre el } \\
\text { Pecho. }\end{array}$ & $\begin{array}{l}\text { Mus } \\
\text { Pestoños }\end{array}$ & $\begin{array}{l}\text { Tenon } \\
\text { Tormode } \\
\text { estar } \\
\text { encresfocts }\end{array}$ & $\begin{array}{l}\text { El } \\
\text { coscopar } \\
\text { de lo } \\
\text { bisa }\end{array}$ & $\begin{array}{l}\text { le doloon } \\
\text { un toque } \\
\text { de coior } \\
\text { o la foto }\end{array}$ & & \\
\hline 8 & $\begin{array}{l}\text { La } \\
\text { Poscición } \\
\text { de lo } \\
\text { cabeza }\end{array}$ & $\begin{array}{l}\text { Fro Poro } \\
\text { verce mos } \\
\text { inclinado }\end{array}$ & $\begin{array}{l}\text { la } \\
\text { Fono y } \\
\text { colorde } \\
\text { la boco }\end{array}$ & $\begin{array}{l}\text { le dobo } \\
\text { groco00 } \\
\text { lo foto }\end{array}$ & $\begin{array}{l}\text { a boso } \\
\text { a } \\
\text { cooons }\end{array}$ & $\begin{array}{l}\text { Le dobo } \\
\text { butezo a } \\
\text { la Tuto } \\
\text { yel color }\end{array}$ & \begin{tabular}{|l|}
6 \\
formodt \\
los \\
cors
\end{tabular} & $\begin{array}{l}\text { Hosiaver } \\
\text { Grousso } \\
\text { la Toto. }\end{array}$ & & \\
\hline 9 & $\begin{array}{l}\text { La formo } \\
\text { de los } \\
\text { cyos. }\end{array}$ & $\begin{array}{l}\text { tace licr lo } \\
\text { imcogen megar } \\
\text { 9 de coler } \\
\text { negro }\end{array}$ & $\begin{array}{l}\text { la } \\
\text { sonmisos }\end{array}$ & $\begin{array}{l}\text { Queria } \\
\text { dorle un } \\
\text { teque de } \\
\text { terengulidat }\end{array}$ & $\begin{array}{l}\text { El } \\
\text { regiods } \\
\text { pus }\end{array}$ & $\begin{array}{l}\text { Ela por } \\
\text { de cereso } \\
\text { de locement }\end{array}$ & buso & 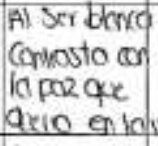 & irnacen. & \\
\hline 10 & $\begin{array}{l}\text { la } \\
\text { Pescición } \\
\text { do corpo }\end{array}$ & $\begin{array}{l}\text { Estribo } \\
\text { uclirdodo } \\
\text { toco yo } \\
\text { centcico }\end{array}$ & $\begin{array}{l}\text { las } \\
\text { mondlas }\end{array}$ & $\begin{array}{l}\text { le clobon } \\
\text { estivo o } \\
\text { la Teto }\end{array}$ & $\begin{array}{l}\text { los } \\
\text { gos }\end{array}$ & $\begin{array}{l}\text { teno earo } \\
\text { lo impreno } \\
\text { de concrio }\end{array}$ & $\begin{array}{l}\text { las } \\
\text { cños }\end{array}$ & $\begin{array}{l}\text { Le criban } \\
\text { on color } \\
\text { distinto a } \\
\text { is toto. }\end{array}$ & $\begin{array}{l}\text { lo } \\
\text { Somino. }\end{array}$ & $\begin{array}{l}\text { le dobo } \\
\text { magor corort- } \\
\text { exroo mi } \\
\text { coro. }\end{array}$ \\
\hline
\end{tabular}


(Mujer de 15 años)

\begin{tabular}{|c|c|c|c|c|c|c|c|c|c|c|}
\hline Yate V & $\begin{array}{c}\text { Elemeatios } \\
\text { senifteative } 1\end{array}$ & Significaute & \begin{tabular}{c|} 
Eementiv \\
sifailicativo 2
\end{tabular} & Signilizado & \begin{tabular}{|c|} 
Elententos \\
dizuibatitio \\
3
\end{tabular} & Significado & 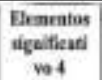 & Segnificiade & $\begin{array}{c}\text { Elementios } \\
\text { significatives } 5\end{array}$ & Squifirata \\
\hline 1 & Magullare & $\begin{array}{l}\text { Poique } \\
\text { ero un } \\
\text { dig } \\
\text { especial }\end{array}$ & $\begin{array}{l}\text { Hombies } \\
\text { eleganter }\end{array}$ & $\begin{array}{l}\text { Borge } \\
\text { el traje. } \\
\text { es parbel| } \\
\text { do espeed }\end{array}$ & do & $\begin{array}{l}\text { ES blancol } \\
\text { poique es } \\
\text { mi paime- } \\
\text { va comu- } \\
\text { nion }\end{array}$ & $\begin{array}{l}\text { Cloner } \\
\text { Con } \\
\text { bela }\end{array}$ & $\begin{array}{l}\text { Porque } \\
\text { me quena } \\
\text { Uer bonito } \\
\text { (Phimasilanm) }\end{array}$ & Cor & $\begin{array}{l}\text { Siento cke } \\
\text { demuestid que } \\
\text { Soy mi Propio } \\
\text { Princessa }\end{array}$ \\
\hline 2 & $\begin{array}{l}\text { Sonrisa } \\
\text { Picakna }\end{array}$ & $\begin{array}{l}\text { Porace } \\
\text { stoba fita } \\
\text { y mes septa } \\
\text { muy bonda }\end{array}$ & $\begin{array}{l}\text { Camisa } \\
\text { Roja }\end{array}$ & $\begin{array}{l}\text { Porgoe, } \\
\text { me cos ta } \\
\text { macho la } \\
\text { camisa }\end{array}$ & Oretes & $\begin{array}{l}\text { Porgue } \\
\text { elos me } \\
\text { hocenver } \\
\text { rodicinle }\end{array}$ & Rertado & $\begin{array}{l}\text { Porque me } \\
\text { hoce ver } \\
\text { may. } \\
\text { linco }\end{array}$ & Pantalon & $\begin{array}{l}\text { Porque es } \\
\text { mi preferido } \\
\text { y se me } \\
\text { ve genial }\end{array}$ \\
\hline 3 & Brillo & $\begin{array}{l}\text { Porcke me } \\
\text { veo Lncla }\end{array}$ & Pose & $\begin{array}{l}\text { Porque } \\
\text { me veo } \\
\text { bien iunt } \\
\text { cim hervas }\end{array}$ & & $\begin{array}{l}\text { Rogke } \\
\text { celeoritan } \\
\text { os ei } \\
\text { mundial }\end{array}$ & $\begin{array}{l}\text { Sonr: } \\
\text { Sas }\end{array}$ & $\begin{array}{l}\text { Borge } \\
\text { estaban os } \\
\text { helices de } \\
\text { yanar }\end{array}$ & $P E_{1} 1$ & $\begin{array}{l}\text { A la mitod } \\
\text { poicue me } \\
\text { gosta ese }\end{array}$ \\
\hline 4 & Sonrísos & 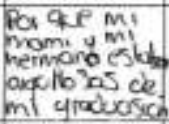 & tes & $\begin{array}{l}\text { Gueria } \\
\text { vernite } \\
\text { an itiad } \\
\text { an mami } \\
\text { wiami }\end{array}$ & Peiveng & $\begin{array}{l}\text { porque me } \\
\text { luce equed } \\
\text { govio }\end{array}$ & Ponqué & $\begin{array}{l}\text { celebruba } \\
\text { mos mi } \\
\text { gradua } \\
\text { cion }\end{array}$ & $\begin{array}{l}\text { Maguilbje } \\
\text { suave }\end{array}$ & $\begin{array}{l}\text { Porckue me } \\
\text { Sentia ys } \\
\text { me vera } \\
\text { bien }\end{array}$ \\
\hline 5 & $\begin{array}{l}\text { Pantalon } \\
\text { ninja }\end{array}$ & $\begin{array}{l}\text { porque } \\
\text { resataba } \\
\text { my } \\
\text { ficura }\end{array}$ & Chacpeta & $\begin{array}{l}\text { Porque } \\
\text { se ve bien } \\
\text { y loce } \\
\text { mucho }\end{array}$ & $\begin{array}{l}\text { top } \\
\text { Blarce }\end{array}$ & $\begin{array}{l}\text { Dorque } \\
\text { tambien } \\
\text { resaltaba } \\
\text { con mica }\end{array}$ & Botos & $\begin{array}{l}\text { Aitas y } \\
\text { negiass } \\
\text { porde se } \\
\text { ve acresivo }\end{array}$ & Mercina & $\begin{array}{l}\text { Dorave quie } \\
\text { verme } \\
\text { mistericbal }\end{array}$ \\
\hline 6 & MoECA & $\begin{array}{l}\text { Porque me } \\
\text { ue fehz } \\
\text { y linda }\end{array}$ & Aretes & $\begin{array}{l}\text { cufes pa } \\
\text { 4e lesaton } \\
\text { con mis } \\
\text { ops }\end{array}$ & Chaquela & $\begin{array}{l}\text { monado } \\
\text { wi que } \\
\text { me hoce, } \\
\text { ver elegard }\end{array}$ & Botas & $\begin{array}{l}\text { Porce me } \\
\text { hacen ver } \\
\text { elecanle }\end{array}$ & fos 6 & $\begin{array}{l}\text { Dorque yo } \\
\text { Sog heira }\end{array}$ \\
\hline
\end{tabular}

\begin{tabular}{|c|c|c|c|c|c|c|c|c|c|c|}
\hline & $\begin{array}{l}\text { Pose } \\
\text { Crenda }\end{array}$ & 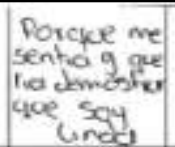 & Sonriso & $\begin{array}{l}\text { Era mi } \\
\text { cumple- } \\
\text { orot y } \\
\text { establ } \\
\text { feliz }\end{array}$ & $\begin{array}{l}\text { Westco } \\
\text { Azul }\end{array}$ & $\begin{array}{l}\text { Porcice } \\
\text { el cizol } \\
\text { claro me } \\
\text { hace ver } \\
\text { serena }\end{array}$ & Peincad & $\begin{array}{l}\text { Porcape } \\
\text { me. } \\
\text { vela } \\
\text { Cindes }\end{array}$ & Brillo & $\begin{array}{l}\text { Sucive } \\
\text { forace } \\
\text { Con el me } \\
\text { des sencilla }\end{array}$ \\
\hline 7 & $\begin{array}{l}80 \times 6 \\
\operatorname{Cog}, 105 A\end{array}$ & $\begin{array}{l}\text { Por clue } \\
\text { moptrobas } \\
\text { goe queio } \\
\text { a mo } \\
\text { hermands }\end{array}$ & Sonvisa & $\begin{array}{l}\text { Paque } \\
\text { telt? me } \\
\text { veo bien }\end{array}$ & Areles & $\begin{array}{l}\text { Dovque } \\
\text { resaltan } \\
\text { con mis } \\
\text { oyos }\end{array}$ & Pllana & $\begin{array}{l}\text { Parqoe } \\
\text { es tievin } \\
\text { y bonita. }\end{array}$ & Do & $\begin{array}{l}\text { Porace ve } \\
\text { hacia ver } \\
\text { sencilla }\end{array}$ \\
\hline 8 & MuEca & $\begin{array}{l}\text { Sacamos } \\
\text { la lengoa } \\
\text { Por que dered } \\
\text { tramos gaco }\end{array}$ & Camisa & $\begin{array}{l}\text { Coconon } \\
\text { y Esqek } \\
\text { to porgue } \\
\text { me ved } \\
\text { inda. }\end{array}$ & Yotos & $\begin{array}{l}\text { muestrar } \\
\text { Deve } \\
y \text { tran } \\
\text { quil.jod }\end{array}$ & Bse & $\begin{array}{l}\text { Dolque } \\
\text { estases } \\
\text { mos } \\
\text { tel, } 2\end{array}$ & PEIVADO & $\begin{array}{l}\text { Era on } \\
\text { compleaños } \\
\text { y nos deva } \\
\text { bos bonitas }\end{array}$ \\
\hline 9 & Santiga & $\begin{array}{l}\text { novicad y } \\
\text { estubamos } \\
\text { felices of } \\
\text { es tor jontes }\end{array}$ & Aretes & $\begin{array}{l}\text { Wueian } \\
\text { con } \\
\text { mis ojos }\end{array}$ & daclem & $\begin{array}{l}\text { Dorace } \\
\text { me } \\
\text { lcce }\end{array}$ & $\begin{array}{l}\text { Cho } \\
\text { queta }\end{array}$ & $\begin{array}{c}\text { me vera } \\
\text { linda } \\
\text { conla } \\
\text { ella }\end{array}$ & Gugar & $\begin{array}{l}\text { Uevimos } \\
\text { las leces } \\
\text { haviderias }\end{array}$ \\
\hline 10 & Gorra & $\begin{array}{l}\text { me veia } \\
\text { bien } \varphi \\
\text { Gnda }\end{array}$ & Gatos & $\begin{array}{l}\text { porace } \\
\text { me vea } \\
\text { genual } \\
\text { con } \\
\text { ellos }\end{array}$ & Sontsa & $\begin{array}{l}\text { estabs } \\
\text { telade } \\
\text { estar con } \\
\text { mis } \\
\text { hemand }\end{array}$ & $\begin{array}{c}P E N_{A} \\
D O\end{array}$ & $\begin{array}{l}\text { Scet to for } \\
\text { qoe me } \\
\text { wera } \\
\text { moy linds }\end{array}$ & abratacos & $\begin{array}{l}\text { Porque } \\
\text { nos } \\
\text { quenomos }\end{array}$ \\
\hline
\end{tabular}


(Mujer de 14 años)

\begin{tabular}{|c|c|c|c|c|c|c|c|c|c|c|}
\hline Foted & $\begin{array}{c}\text { Eleraentas } \\
\text { signiflentive } 1\end{array}$ & Sigaificate & 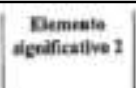 & Signifleade & $\left|\begin{array}{c}\text { Evanates } \\
\text { sigullication } \\
3\end{array}\right|$ & Siquificato & 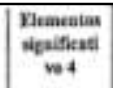 & Sqguificade & 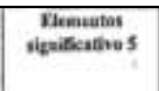 & Significade \\
\hline 1 & 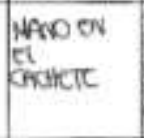 & 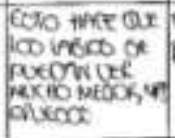 & $\begin{array}{l}\text { Fono: } \\
607000\end{array}$ & 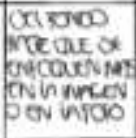 & \begin{tabular}{|l|} 
ceans \\
subuons
\end{tabular} & $\begin{array}{l}\text { Pre exe } \\
\text { cow ingor } \\
1000005\end{array}$ & $\begin{array}{l}\text { crobilo } \\
\text { ck la } \\
\text { orea }\end{array}$ & 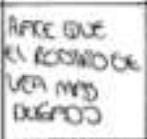 & MPQulfoE & $\begin{array}{l}\text { Ecrean } \\
\text { inperftcrones }\end{array}$ \\
\hline 2 & $\begin{array}{l}\text { crovela } \\
\text { mialA }\end{array}$ & $\begin{array}{l}\text { Pron ax } n \\
\text { PaD st unst } \\
\text { carealo }\end{array}$ & SONRSA & $\begin{array}{l}\text { Fonervia } \\
\text { A Felicoon }\end{array}$ & $\begin{array}{l}\text { mero eN } \\
\text { loosh }\end{array}$ & 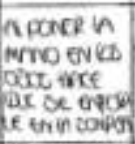 & $\begin{array}{l}\text { ronos } \\
\text { sonicito }\end{array}$ & 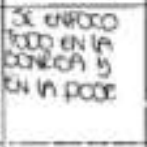 & Filteo & 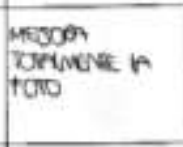 \\
\hline 3 & $\begin{array}{l}\text { fitiro } \\
\text { genco y } \\
\text { neces }\end{array}$ & $\begin{array}{l}\text { necosolo } \\
\text { oringive } \\
\text { in polo }\end{array}$ & PिCO & $\begin{array}{l}\text { fropomo } \\
\text { orlardo }\end{array}$ & Mervo & 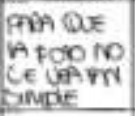 & $\begin{array}{l}\cos 0 \\
\operatorname{sis} 0 A\end{array}$ & $\begin{array}{l}\text { ifre al el } \\
\text { PAROO No } \\
\text { Se UfA } \\
\text { CAOS }\end{array}$ & $\begin{array}{l}\text { frrecoriol } \\
\text { fresine }\end{array}$ & 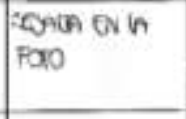 \\
\hline 4 & Sheson & $\begin{array}{l}\text { nerecivon } \\
\text { reluciono }\end{array}$ & $\begin{array}{l}\text { foros } \\
\text { 8ofectsos }\end{array}$ & 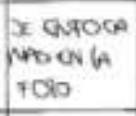 & $\begin{array}{l}\text { CEA } \\
\text { iserrmp }\end{array}$ & $\begin{array}{l}\text { O puod } \\
\text { Ge mas } \\
\text { riefCiuA }\end{array}$ & fittreo & $\begin{array}{l}\text { NESTA } A \\
\text { FOTS }\end{array}$ & UMincsono & $\begin{array}{l}\text { insonata } \\
\text { kasto }\end{array}$ \\
\hline 3 & FBAL & $\begin{array}{l}\text { cracos } \\
\text { hins } \\
\text { chess }\end{array}$ & PEETCS & $\begin{array}{l}\text { Se ve } \\
\text { Nos } \\
\text { Femevero }\end{array}$ & Filaro & $\begin{array}{l}\text { MOOEA } \\
\text { AC Fots }\end{array}$ & MUANCA & sonsul. & CActetes & TEENGEA \\
\hline 5 & ooversa & $\begin{array}{l}\text { fPevertia } \\
\text { Felición }\end{array}$ & $\begin{array}{l}\text { frecro } \\
\text { Giprico y } \\
\text { Neceo }\end{array}$ & $\begin{array}{l}\text { hoo la } \\
\text { foto }\end{array}$ & $\begin{array}{l}\text { MANOCAN } \\
\text { TOECA }\end{array}$ & 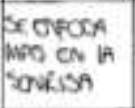 & $\begin{array}{l}\text { L twivry } \\
\text { Dono }\end{array}$ & $\begin{array}{l}\text { feonin } n \\
\text { toto }\end{array}$ & $\begin{array}{l}\text { ronos } \\
\text { sorecoco }\end{array}$ & $\begin{array}{l}\text { A ther use } \\
\text { exivesilo }\end{array}$ \\
\hline
\end{tabular}

\begin{tabular}{|c|c|c|c|c|c|c|c|c|c|c|}
\hline Fout & $\begin{array}{l}\text { Cterentas } \\
\text { Stanifenad }\end{array}$ & SGNACROD & 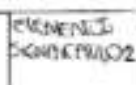 & Suanfionusa & 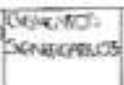 & Scrnegirno & 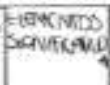 & 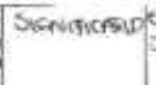 & 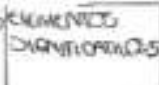 & SEAVITCPINOS \\
\hline 7 & $\begin{array}{l}\text { NAfivo } \\
\text { EN EI } \\
\text { CFCHETE }\end{array}$ & $\begin{array}{l}\text { No IA } \\
\text { incia veE } \\
\text { TAw Soupte }\end{array}$ & $\begin{array}{l}\text { fore neD } \\
\text { fícsa }\end{array}$ & 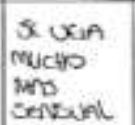 & Orरol & $\begin{array}{l}\text { Tepo IA } \\
\text { mptreceos } \\
\text { ak endia }\end{array}$ & filtieo & $\begin{array}{l}\text { MEDORA } \\
\text { PA TOLO }\end{array}$ & GBIAL & $\begin{array}{l}\text { hercos } \\
\text { severos }\end{array}$ \\
\hline n & PlCO & $\begin{array}{l}\text { leficts } \\
\text { cavecoss }\end{array}$ & Honduganta & Seromingo & $\begin{array}{l}\text { fanco } \\
\text { Bancoso }\end{array}$ & $\begin{array}{l}\text { Thoo ro } \\
\text { bue thin } \\
\text { ev Fonmo }\end{array}$ & Fitroo & 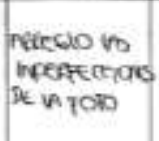 & scelular & $\begin{array}{l}\text { rome un zolo } \\
\text { conel } \\
\text { rosponcolo } \\
\text { Giv lardo }\end{array}$ \\
\hline 9 & ioneriof & $\begin{array}{l}\text { Porecsin } \\
\text { Fetuciono }\end{array}$ & 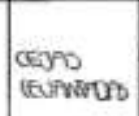 & $\begin{array}{l}\text { restita } \\
\text { pos wos } \\
0500\end{array}$ & $\begin{array}{l}\text { Motulh } \\
\text { xe }\end{array}$ & $\begin{array}{l}\text { borma } \\
\text { nperfocom }\end{array}$ & $\begin{array}{l}\text { Wuros } \\
\text { TAD }\end{array}$ & $\begin{array}{l}\text { RESTISA } \\
\text { LA RITO }\end{array}$ & $\begin{array}{l}\text { Fonios } \\
\text { tofficos }\end{array}$ & $\begin{array}{l}\text { LA HARE } \\
\text { Uer con } \\
\text { Etlo }\end{array}$ \\
\hline 10 & Mrquirex & $\begin{array}{l}\text { 6orea } \\
\text { mpterecouss }\end{array}$ & $\begin{array}{l}\text { AFNO EN } \\
\text { WA COAA }\end{array}$ & $\begin{array}{l}\text { bo HACE } \\
\text { Gel moOS } \\
\text { SenSUAL }\end{array}$ & $\begin{array}{l}6000 \\
\text { AnCHO }\end{array}$ & $\begin{array}{l}\sec x \\
\cos 1 \\
\cot (0)\end{array}$ & $\begin{array}{l}\text { Fando } \\
\text { tareoso }\end{array}$ & $\begin{array}{l}\text { SE ENHCAA } \\
\text { WAI GN IA } \\
\text { WHECN }\end{array}$ & Filreo & $\begin{array}{l}\text { MEJdA LA } \\
\text { FOS }\end{array}$ \\
\hline
\end{tabular}


11.8 H. Muestras de mapas semánticos completados por jóvenes: instrumento 3 (Mujer de 16 años)

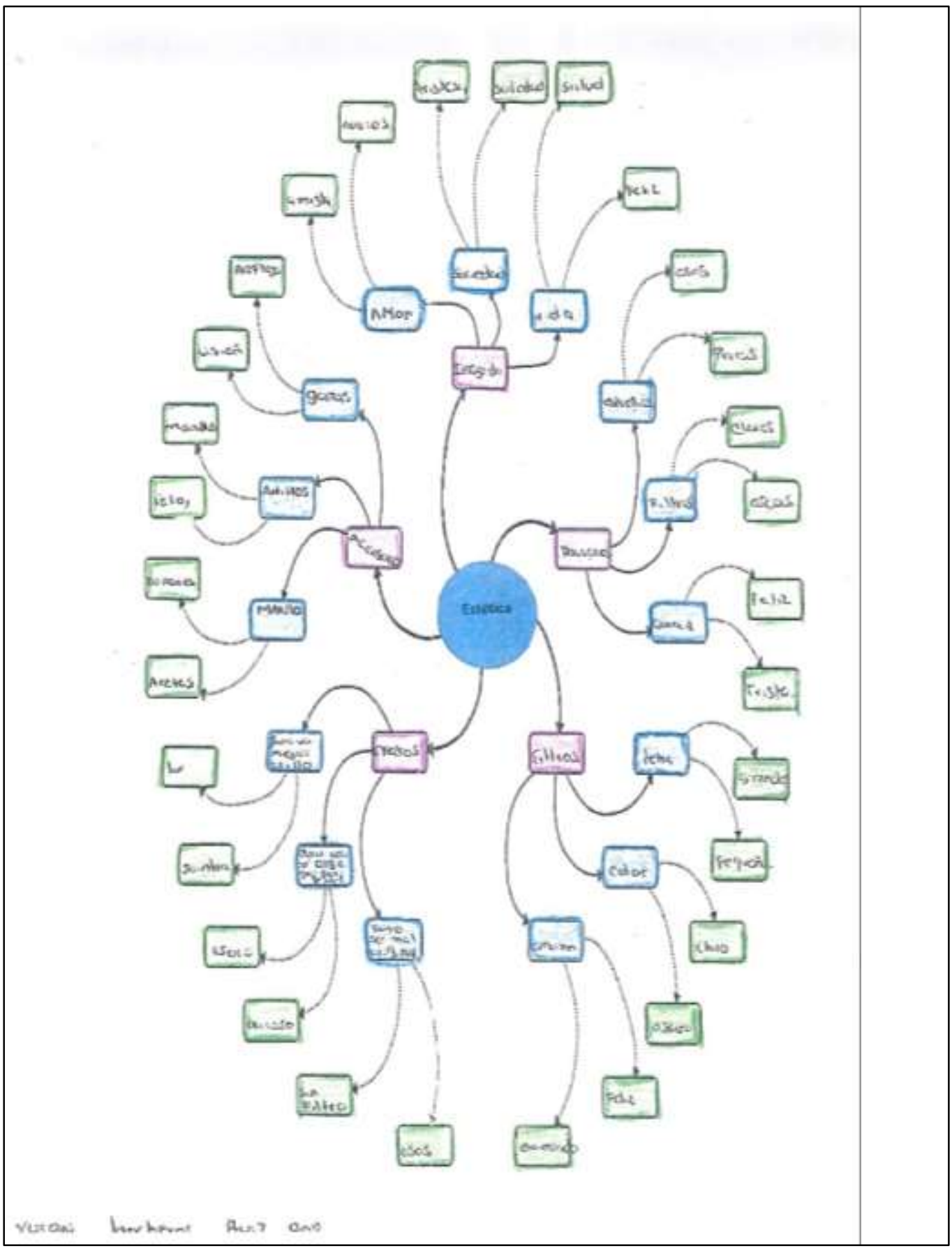


(Hombre de 15 años)

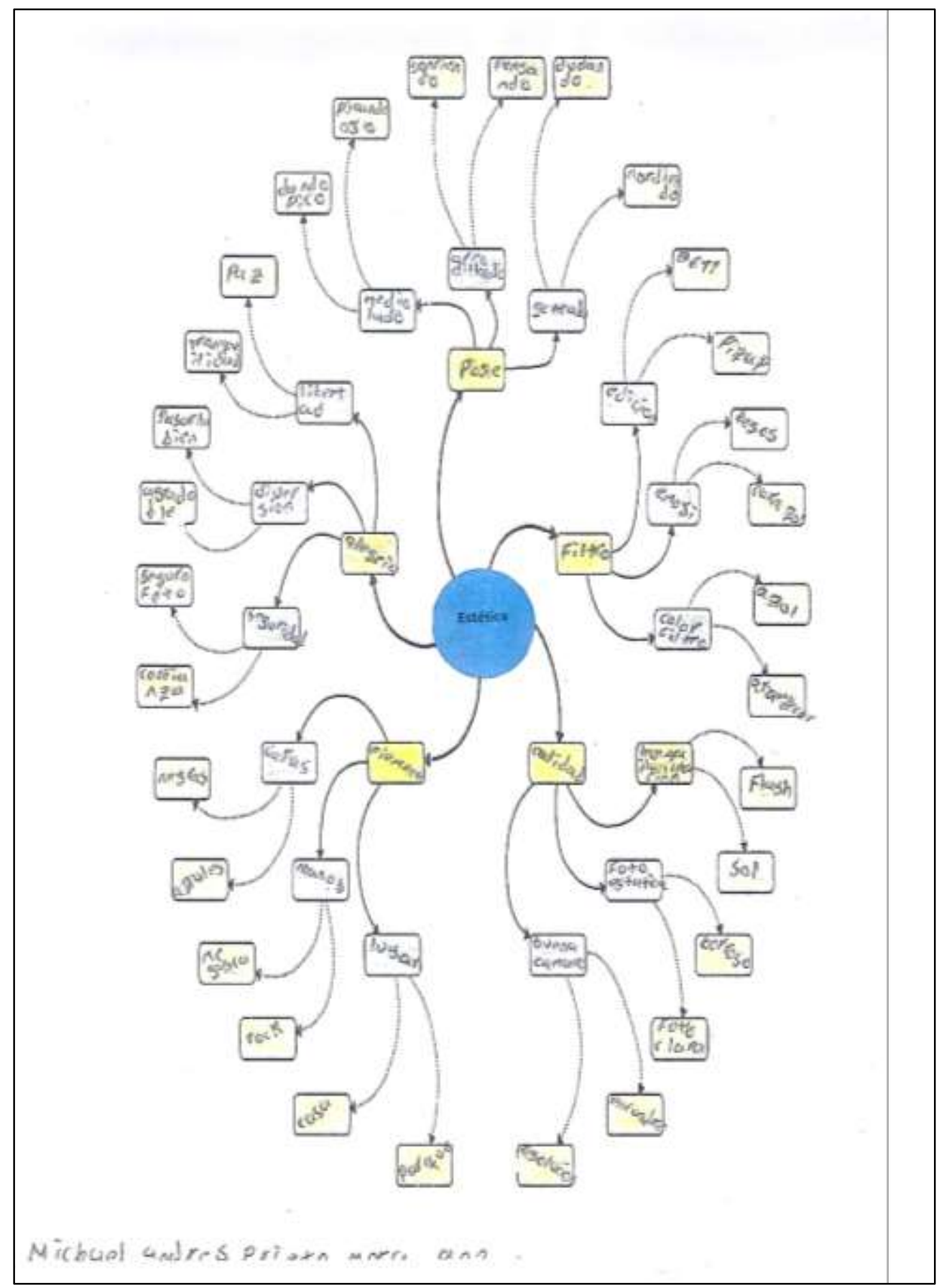


(Mujer de 14 años)

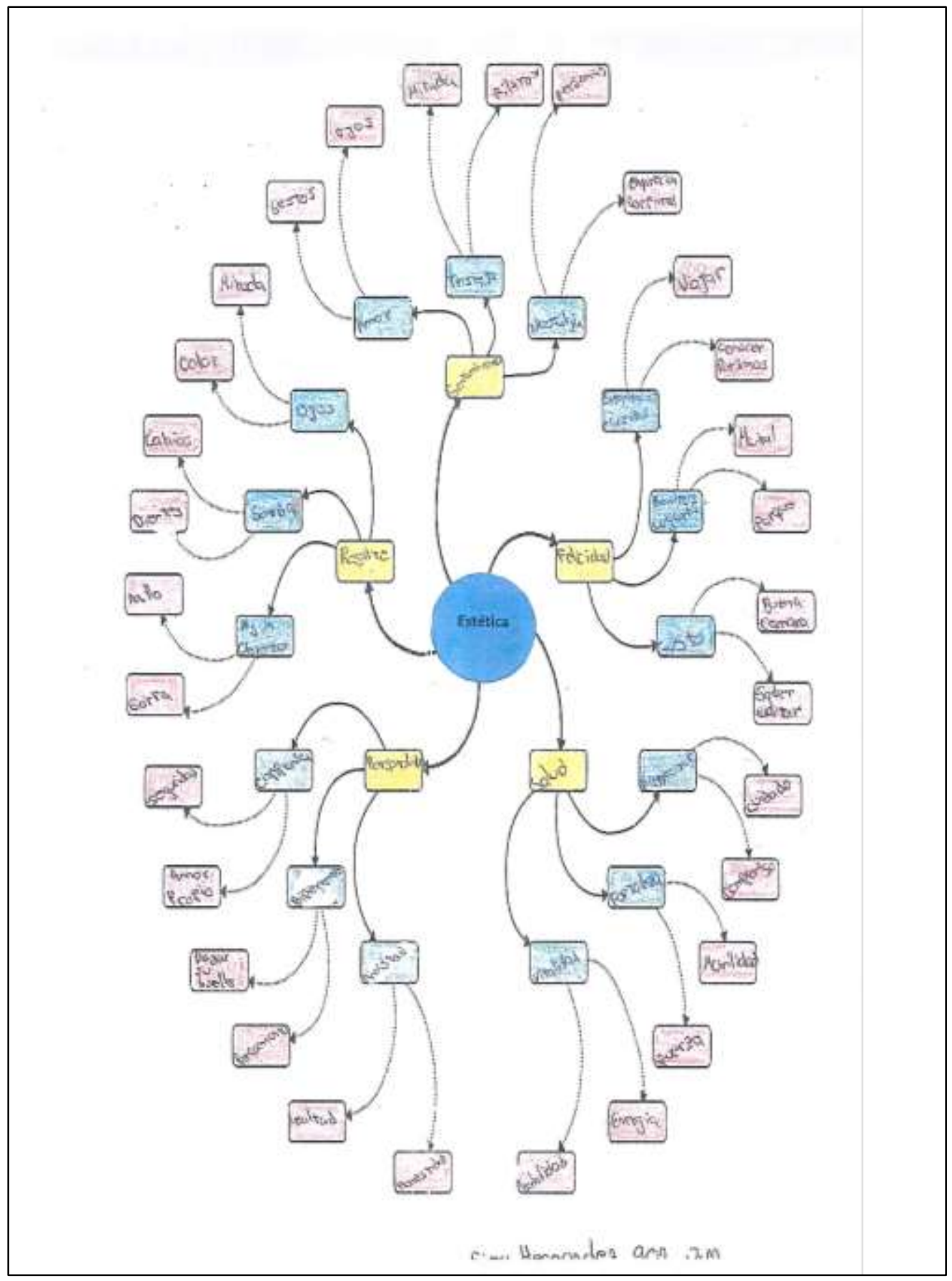


